UNIVERSIDADE DE SÃO PAULO

FACULDADE DE FILOSOFIA, LETRAS E CIÊNCIAS HUMANAS

DEPARTAMENTO DE LETRAS MODERNAS

PROGRAMA DE PÓS-GRADUAÇÃO EM ESTUDOS LINGUÍSTICOS, LITERÁRIOS E TRADUTOLÓGICOS EM FRANCÊS

FERNANDA SOARES

\title{
Aprendizagem do trabalho de ensinar pelo
}

\author{
professor iniciante
}

Versão Corrigida

São Paulo

2016 
FERNANDA SOARES

\title{
Aprendizagem do trabalho de ensinar pelo
}

\author{
professor iniciante
}

Dissertação apresentada ao Programa de PósGraduação em Estudos Linguísticos, Literários e Tradutológicos em Francês do Departamento de Letras Modernas da Faculdade de Filosofia, Letras e Ciências Humanas da Universidade de São Paulo, para obtenção do título de Mestre em Letras, Língua e Literatura Francesa.

Área de concentração: Línguas Estrangeiras Modernas; Estudos Linguísticos em Francês

Orientadora: Profa. Dra. Eliane Gouvêa Lousada

Versão Corrigida

São Paulo 
Autorizo a reprodução e divulgação total ou parcial deste trabalho, por qualquer meio convencional ou eletrônico, para fins de estudo e pesquisa, desde que citada a fonte.

Catalogação na Publicação

Serviço de Biblioteca e Documentação

Faculdade de Filosofia, Letras e Ciências Humanas da Universidade de São Paulo

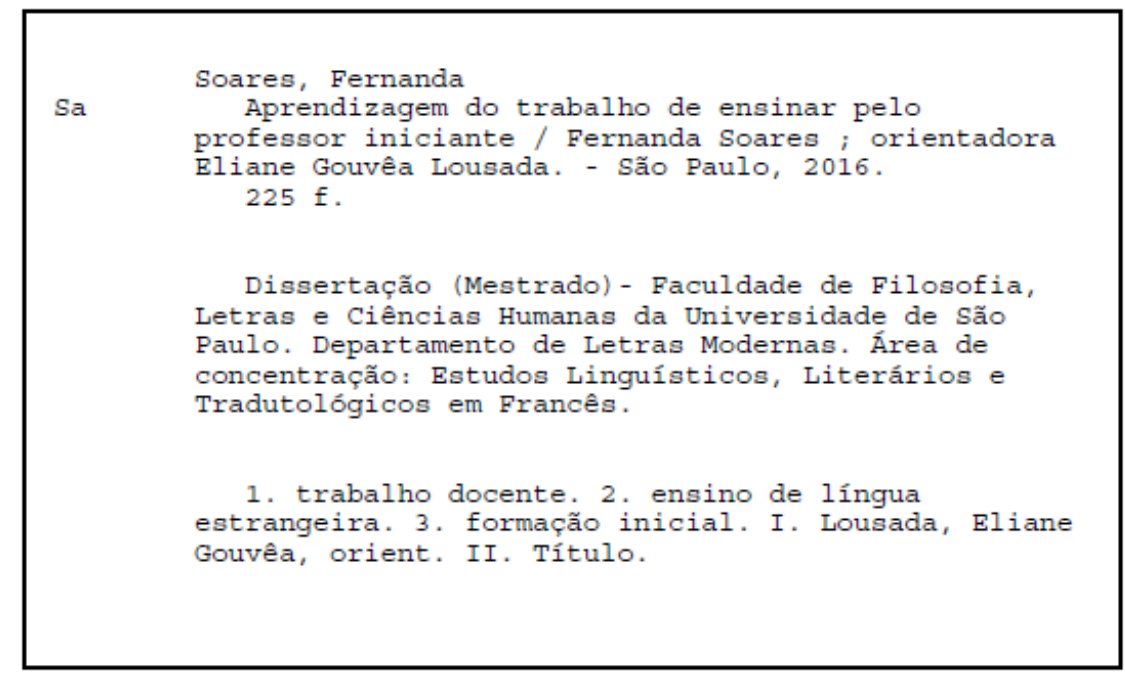


Nome: SOARES, Fernanda.

Título: Aprendizagem do trabalho de ensinar pelo professor iniciante.

Dissertação apresentada ao Programa de PósGraduação em Estudos Linguísticos, Literários e Tradutológicos em Francês do Departamento de Letras Modernas da Faculdade de Filosofia, Letras e Ciências Humanas da Universidade de São Paulo, para obtenção do título de Mestre em Letras, Língua e Literatura Francesa.

Aprovado em:

Banca Examinadora

Profa. Dra. Eliane Gouvêa Lousada

Julgamento:

Profa. Dra. Ermelinda Barricelli

Julgamento:

Profa. Dra. Heloisa Albuquerque Costa

Julgamento:

Profa. Dra. Elvira Lopes Nascimento

Julgamento:

Profa. Dra. Fernanda Ortale

Julgamento:

Profa. Dra. Vera Lúcia Lopes

Cristovão

Julgamento:
Instituição: USP

Assinatura:

Instituição: FAMESP

Assinatura:

Instituição: USP

Assinatura:

Instituição: UEL

Assinatura:

Instituição: USP

Assinatura:

Instituição: UEL

Assinatura: 
Aos meus pais Célia e Paulo e ao meu marido Edmar, dedico esta dissertação com muito amor. 


\section{AGRADECIMENTOS}

A Eliane Lousada, minha orientadora, a quem tanto admiro, agradeço pela acolhida inicial, pelas orientações e correções, que deixavam o percurso mais iluminado, e pelas palavras carinhosas nos momentos mais difíceis.

A Ermelinda Barricelli e Heloisa Albuquerque Costa, pelas valiosas contribuições durante o exame de qualificação.

A Mariana Barioni e Flávia Fazion, por participarem desta pesquisa, deixando-a mais leve e divertida.

A todos os colegas do grupo de pesquisa ALTER-AGE, pelas discussões e auxílio para o avanço deste trabalho.

À CAPES, pelo apoio concedido para que esta pesquisa se realizasse.

Aos meus colegas de trabalho das diferentes escolas pelas quais passei, em especial: Sônia Iraci Siqueira, por sempre me mostrar o lado mais belo em ser professor.

A toda minha família e amigos, pelo apoio, força e torcida.

À minha tia Márcia, que me inspira a estudar desde a minha infância, quando carregava muito livros em seus braços.

A Paula, minha irmã, agradeço por me ensinar tantas coisas e estar presente em todos os momentos.

Aos meus pais, Célia e Paulo, que se dedicaram para que as filhas tivessem uma boa educação, agradeço pelo incentivo constante e por serem tão carinhosos.

A Edmar, meu marido, por me ajudar em todas as etapas do mestrado, agradeço por ser compreensível e participativo. 


\section{RESUMO}

SOARES, F. Aprendizagem do trabalho de ensinar pelo professor iniciante. 2016. 225f. Dissertação (Mestrado). Faculdade de Filosofia, Letras e Ciências Humanas da Universidade de São Paulo. São Paulo, 2016.

Esta dissertação tem como objetivo geral compreender o trabalho do professor iniciante de FLE no contexto dos cursos Extracurriculares de francês da FFLCH- USP. Esse estudo é realizado por meio de análises de textos presentes na situação de trabalho e produzidos por esse professor antes e depois de suas aulas. Nosso interesse é estudar o papel das prescrições/orientações no trabalho desse professor, procurando entender como elas afetam seu trabalho. Pretendemos, também, investigar a atividade do professor a partir do que ele diz sobre seu próprio trabalho e sobre si mesmo enquanto professor nesse contexto. Consideramos, ao lado de Clot (1999) que, para entender o trabalho do professor, deve-se levar em conta o que é pedido para esse trabalhador realizar, o que ele de fato realizou e também o que queria ter realizado, mas que por algum motivo não realizou. Para atingir nossos objetivos, investigamos três textos: i) o documento que orienta o trabalho do professor do contexto estudado; ii) diários de aulas escritos, por esse professor, após suas aulas e iii) textos de entrevistas de instrução ao sósia com o professor sobre seu trabalho. O quadro teórico maior que sustenta esta pesquisa é o do interacionismo social, desenvolvido por Vygotski (1927-2009) e duas de suas vertentes: o interacionismo sociodiscursivo (ISD) (BRONCKART, 1999/2009, 2006, 2008), utilizado como embasamento teórico para a compreensão do trabalho do professor como uma forma de agir e para a análise de todos os textos, fornecendo um modelo de análise textual. Paralelamente aos pressupostos teóricos do ISD, apoiamo-nos também em alguns conceitos das vertentes das ciências do trabalho, mais precisamente, a ergonomia da atividade (AMIGUES, 2002; 2004; 2013; SAUJAT, 2004) e a clínica da atividade (CLOT, 1999, 2001; FAÏTA, 2002, 2004), linhas teóricas que propõem alguns procedimentos que possibilitam a criação de diálogos sobre a atividade de trabalho, como o método de intervenção de instrução ao sósia, utilizado neste estudo. Os resultados de nossas análises revelam alguns recursos intermediários elaborados pelo professor iniciante para superar os obstáculos, em seu contexto de trabalho, no processo de transição entre a vida de aluno e a vida de professor. Dentre as contribuições, propomos uma reflexão sobre o papel dos diários de aulas e do método de intervenção "instrução ao sósia" na formação inicial de professores.

PALAVRAS-CHAVE: trabalho docente; ensino de língua estrangeira; formação inicial. 


\begin{abstract}
This dissertation has as its broad objective to understand the work of the beginner teacher of FFL in the context of extracurricular courses of French at FFLCH-USP. This study is carried out through the analysis of the texts which are present in the situation of work and those produced by the teacher before and after his classes. Our main interest is to study the role of the prescriptions/orientations in the work of this teacher, trying to understand how they affect his work. We also aim to investigate the activity of the teacher according to what he says about his own work and about himself as a teacher in this context. We have also considered, according to Clot (1999) that, in order to understand the work of a teacher, it must also be taken into consideration what this worker is asked to carry out, what he actually did and also what he could have done, but for some reason could not do it. In order to achieve our goals, we have investigated three texts: i) the document which orients the work of the teacher in the context studied; ii) teaching diaries written by this teacher after his classes and iii) texts of interviews of instruction to the double with the teacher after his work. The theoretical background that gives basis to this research is the social interactionism developed by Vygotski (1927-2009) and two of its features: the socio-discursive interactionism (SDI) (BRONCKART, 1999/2009,2006,2008), used as theoretical basis for the comprehension of the work of the teacher as a way of acting and for the analysis of all the texts, giving a model of textual analysis. In parallel to the theoretical assumptions of the SDI, we have also used as basis some of the concepts of the branches of the sciences of work, more precisely, the ergonomics of the activity (AMIGUES, 2002; 2004; 2013; SAUJAT, 2004) and the activity-clinic (CLOT, 1999, 2001; FAÏTA, 2002, 2004), theoretical trends which propose some procedures that allow the creation of dialogues about the activity of work, as a method of intervention of instruction to the double, used in this study. The results of this analysis reveal some intermediate resources elaborated by the beginner teacher in order to overcome obstacles, in his context of work, in the process of the transition between the life as a student and the life as a teacher. Among these contributions, we proposed some thought about the role of the teaching diaries and the methods of intervention "instruction to the double" in the professional qualification of teachers.
\end{abstract}

KEY WORDS: teaching, teaching of foreign languages, initial qualification. 


\section{RÉSUMÉ}

Ce mémoire a pour but général de comprendre le travail du professeur débutant de FLE dans le contexte des Cours Extra-universitaires de Français de la FFLCH-USP. Cette étude est réalisée à travers l'analyse des textes présents dans la situation de travail et qui sont produits par le professeur avant et après ses cours. Notre intérêt est celui d'étudier le rôle des prescriptions/orientations dans le travail de ce professeur, en cherchant à comprendre comment elles affectent son travail. Nous nous proposons aussi de faire une investigation de l'activité du professeur à partir de ce qu'il dit sur son propre travail et sur soi-même en tant que professeur dans ce contexte. Nous considérons, à côté de Clot (1999), que pour comprendre le travail du professeur, il faut examiner la tâche qui doit être réalisée par les professeurs, mais aussi, ce qui se fait, ce qui ne se fait pas, ce que l'on cherche à faire, ce que l'on aurait voulu ou pu faire et ce qu'il voulait faire, mais que, pour une raison quelconque, il n'a pas fait. Pour atteindre nos objectifs, nous examinons trois textes: i) un document qui oriente le travail du professeur dans le contexte étudié ; ii) des journaux de cours écrits par ce professeur après ses cours e iii) des textes d'entretiens d'instruction au sosie avec le professeur sur son travail. Le cadre théorique majeur qui soutient cette recherche est celui de l'interactionnisme social, développé par Vygotski (1927-2009) et deux courants de ce cadre majeur qui étudient le travail: l'interactionnisme socio-discursif (ISD) (BRONCKART, 1999/2009, 2006, 2008), qui nous fournit un modèle d'analyse de textes, et l'ergonomie de l'activité (AMIGUES, 2002; 2004; 2013; SAUJAT, 2004) et la clinique de l'activité (CLOT, 1999; 2001; FAÏTA, 2002, 2004) qui proposent des méthodes qui cherchent à nourrir des dialogues professionnels au sein des collectifs, ainsi que la procédure d'instruction au sosie utilisée dans cette étude. Les résultats de nos analyses révèlent quelques ressources intermédiaires élaborées par le professeur débutant pour surmonter les difficultés dans ce contexte de travail, dans la transition entre sa vie d'un élève et sa vie d'un enseignant. Parmi les contributions de cette recherche, nous soulignons la réflexion sur le rôle des journaux de cours et de la méthode d'intervention d'instruction au sosie dans la formation initiale des enseignants.

MOTS-CLÉS : travail enseignant ; enseignement de langues étrangères ; formation initiale. 


\section{LISTA DE QUADROS:}

Quadro 1: Total de dissertações e teses sobre o professor iniciante.

Quadro 2: O perfil do professor iniciante em dissertações e teses.

Quadro 3: Adaptação do modelo de síntese do ciclo de vida profissional dos professores de Huberman.

Quadro 4: As perguntas e objetivos da pesquisa.

Quadro 5: Síntese do Plano Global dos Conteúdos Temáticos do texto "Entrevista com Marli André"

Quadro 6: Tipos de discursos (BRONCKART, 1999/2009, p.157)

Quadro 7: Tabela de níveis das turmas dos cursos Extracurriculares

Quadro 8: Data de coleta e geração de dados

Quadro 9: Diários de aulas e as datas de suas produções

Quadro 10: Datas e duração dos procedimentos instruções ao sósia

Quadro 11: Síntese dos dados coletados ou gerados e dos dados analisados

Quadro 12: Categorias do modelo de análise do ISD usadas para as análises dos dados de pesquisa

Quadro 13: As questões da pesquisa e as categorias de análise.

Quadro 14: Os conteúdos temáticos do diário de aula I de Mariana

Quadro 15: Os conteúdos temáticos do diário de aula II de Mariana

Quadro 16: Os conteúdos temáticos do diário de aula III de Mariana

Quadro 17: Os conteúdos temáticos do diário de aula IV de Mariana

Quadro 18: As figuras humanas presentes nos diários de aula

Quadro 19: Síntese do Plano Global dos Conteúdos Temáticos da $1^{\mathrm{a}}$ Instrução ao Sósia

Quadro 20: Síntese do Plano Global dos Conteúdos Temáticos da Discussão da $1^{\text {a }}$ Instrução ao Sósia

Quadro 21: Síntese do Plano Global dos Conteúdos Temáticos do Retorno à $1^{\text {a }}$ Instrução ao Sósia

Quadro 22: Quantidade de turnos na $1^{\mathrm{a}}$ IS e no Retorno da $1^{\mathrm{a}}$ IS

Quadro 23: Os significados do pronome on na Primeira IS

Quadro 24: Os participantes da situação de trabalho de Mariana

Quadro 25: O programa de tutoria retomado na IS

Quadro 26: Síntese do Plano Global dos Conteúdos Temáticos da $2^{\mathrm{a}}$ Instrução ao Sósia

Quadro 27: Síntese do Plano Global dos Conteúdos Temáticos da Discussão da $2^{\text {a }}$ Instrução ao Sósia

Quadro 28: Síntese do Plano Global dos Conteúdos Temáticos do Retorno à $2^{\mathrm{a}}$ Instrução ao Sósia

Quadro 29: os pronomes “je” e "tu” utilizados nas duas Instruções ao Sósia

Quadro 30: Quantidade de turnos na $2^{\mathrm{a}}$ IS e no Retorno da $2^{\mathrm{a}}$ IS

Quadro 31: A retomada das figuras humanas da segunda IS

\section{LISTA DE FIGURAS:}

Figura 1: Captura de tela do site Nova Escola

Figura 2: Capa da edição 266 da revista Nova Escola

Figura 3: O modelo de arquitetura textual reajustado de acordo com recentes mudanças no ISD

Figura 4: Conjunto central dos dados de nossa pesquisa, com base em Bronckart (2008, p.132)

Figura 5: Formação do coletivo e os procedimentos de seleção de dados 


\section{Sumário}

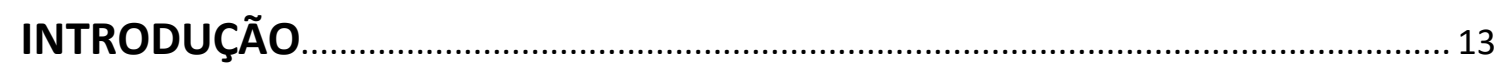

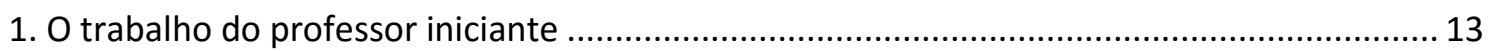

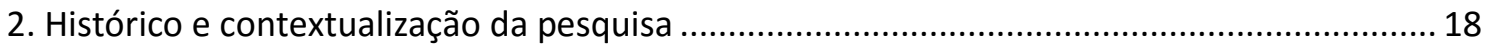

3. O grupo ALTER-AGE e quadro teórico-metodológico adotado............................................... 21

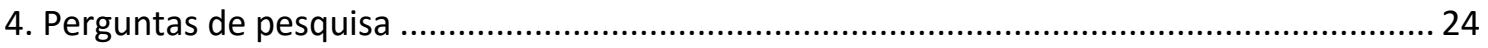

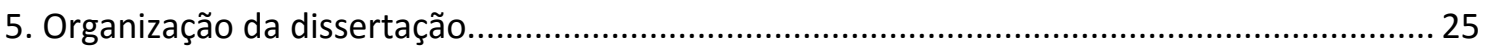

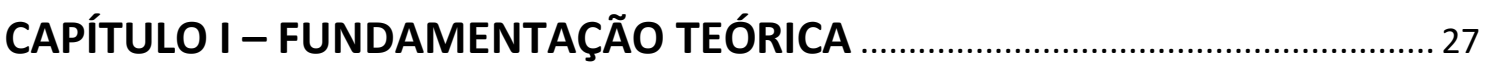

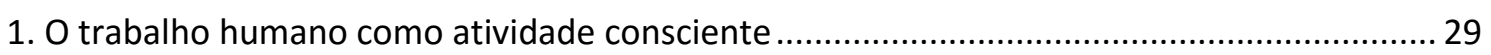

1.1. Os estudos sobre o trabalho e sobre o trabalho educacional .......................................... 33

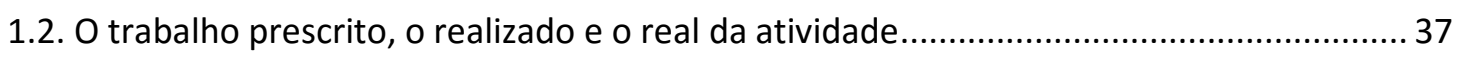

1.3. A Instrução ao Sósia como método de transformação ..................................................... 44

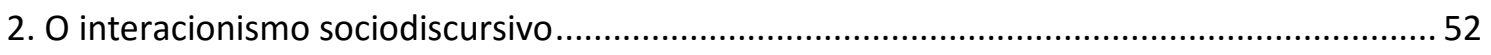

2.1. O agir, o trabalho como forma de agir e os textos produzidos em situação de trabalho 56

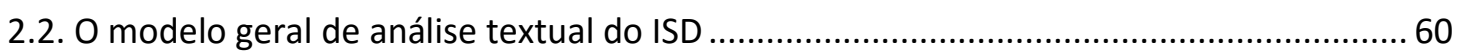

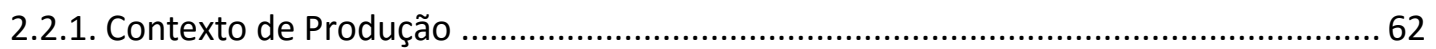

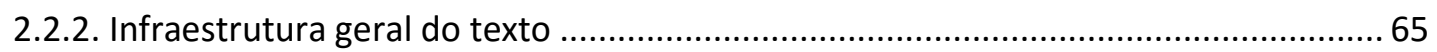

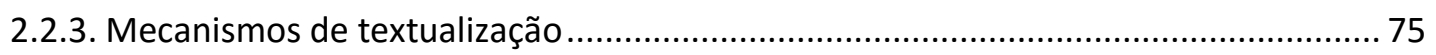

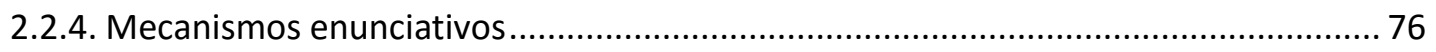

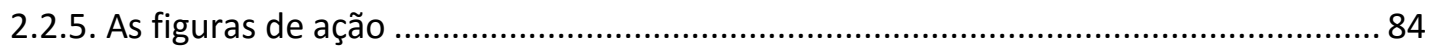

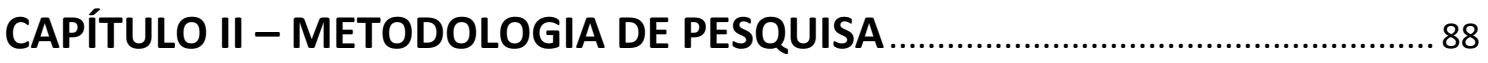

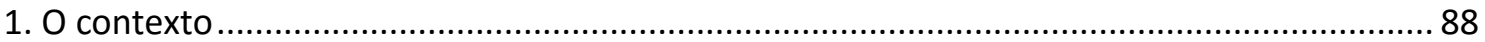

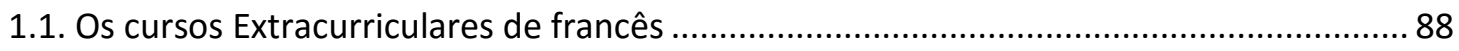

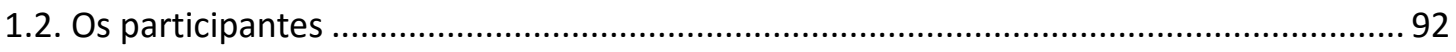

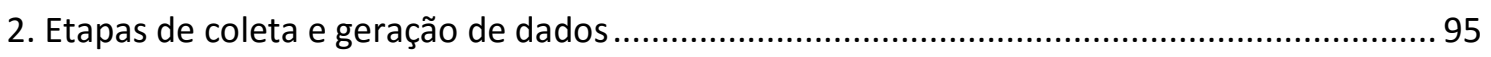

2.1. O Guide du Moniteur dos cursos Extracurriculares de francês.......................................... 96

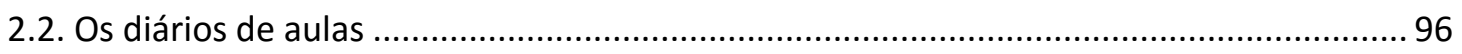

2.3. Instruções ao sósia e retornos às instruções ao sósia ..................................................... 97

3. A constituição do coletivo e os procedimentos de seleção de dados .................................... 98

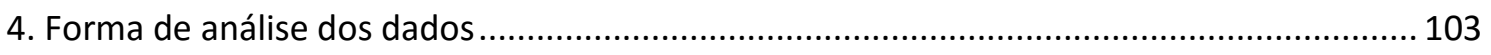

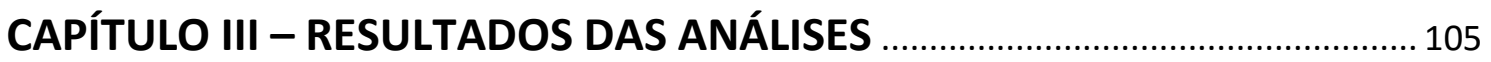

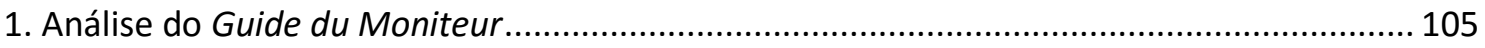

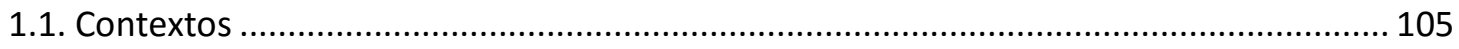

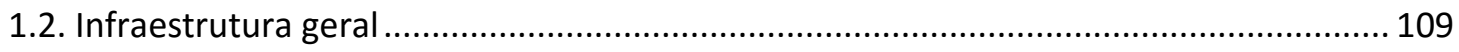


1.3. Mecanismos de textualização

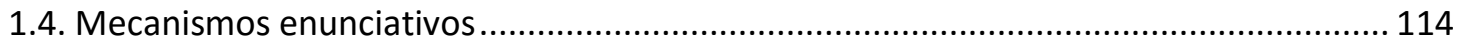

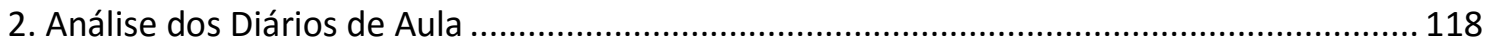

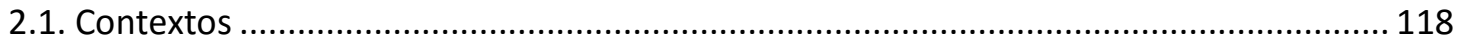

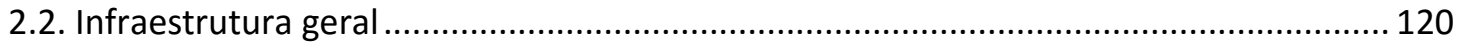

2.3. Mecanismos de textualização ....................................................................................... 123

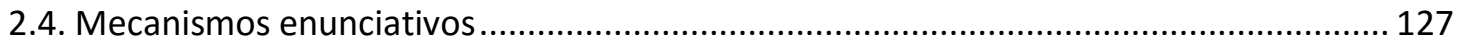

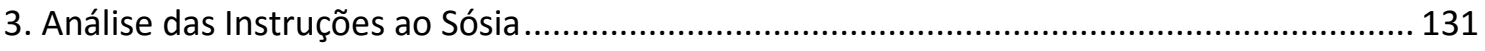

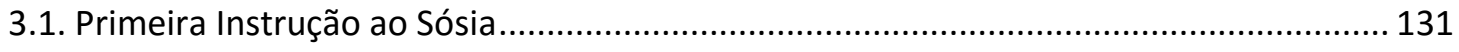

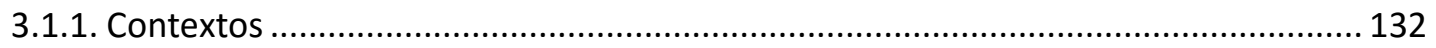

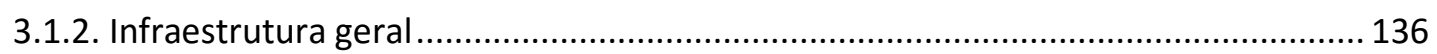

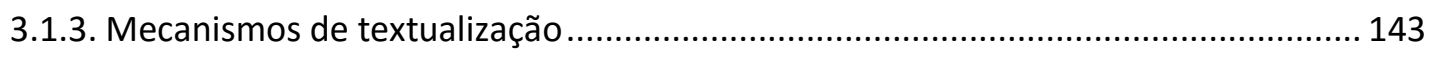

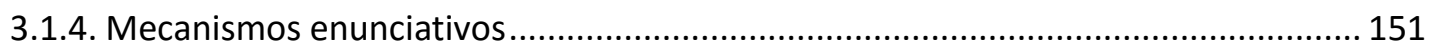

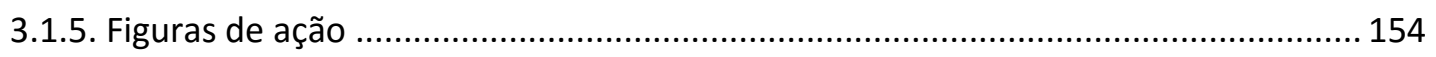

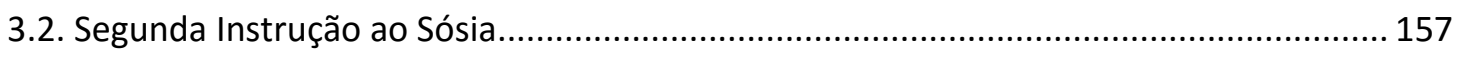

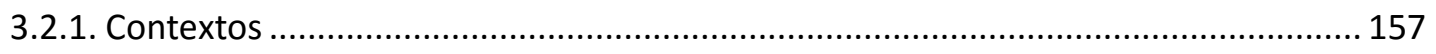

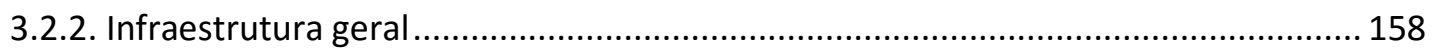

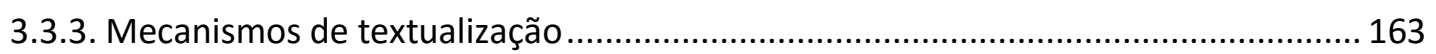

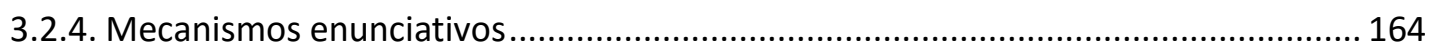

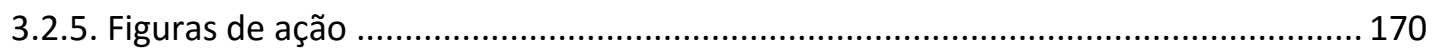

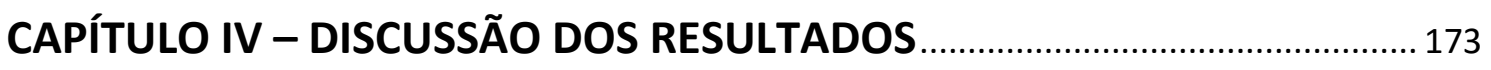

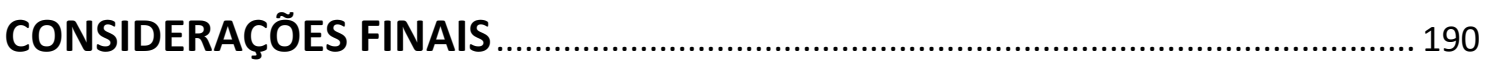

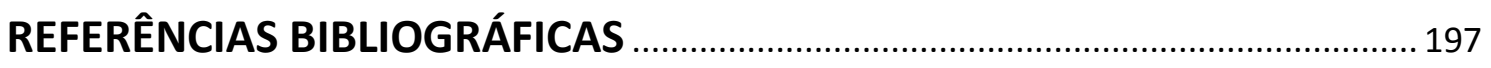

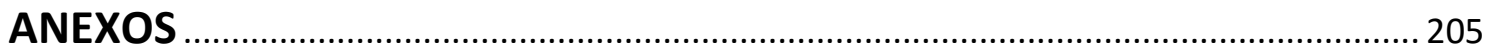

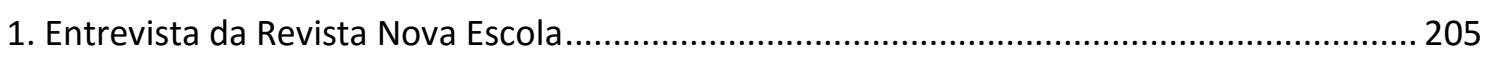

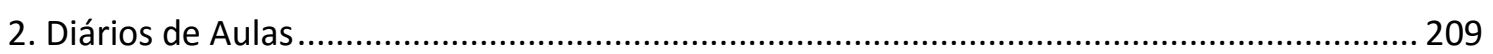

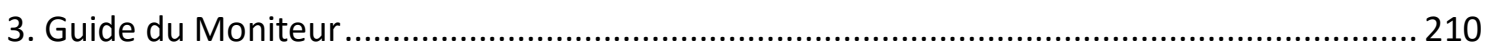




\section{INTRODUÇÃO}

Este trabalho insere-se no conjunto de estudos desenvolvidos no grupo de pesquisa ALTER-AGE (Análise de Linguagem, Trabalho e suas Relações - Aprendizagem, Gêneros Textuais e Ensino) com registro no $\mathrm{CNPq}_{\text {, do qual faço }}{ }^{1}$ parte. Em conformidade com os estudos desenvolvidos por esse grupo, esta pesquisa tem por objetivo geral compreender o trabalho do professor iniciante de francês língua estrangeira (doravante, FLE) no contexto de um curso de extensão - os cursos Extracurriculares de francês da Faculdade de Filosofia, Letras e Ciências Humanas da Universidade de São Paulo (FFLCH-USP). Sendo assim, pretendemos: i) estudar o papel das prescrições/orientações no trabalho desse professor, procurando investigar como elas afetam seu trabalho e ii) estudar a atividade do professor a partir do que ele diz sobre seu próprio trabalho e sobre si mesmo enquanto professor nesse contexto. Respondendo a esses objetivos específicos, visamos a refletir, de forma global, sobre como um professor iniciante aprende o trabalho de ensinar.

Para tanto, propomos, inicialmente, um levantamento de estudos já realizados no Brasil sobre o professor iniciante. Em seguida, apresentamos como a presente pesquisa se constituiu, assim como o grupo de pesquisa no qual ela se insere e seu quadro teóricometodológico. Também, expomos nossas perguntas e os objetivos e, finalmente, mostramos como organizamos este trabalho.

\section{O trabalho do professor iniciante}

Para inserir nossa pesquisa no quadro de estudos realizados no Brasil sobre o trabalho do professor que está em seus primeiros anos de carreira, em agosto de 2014, realizamos uma pesquisa no banco de teses e dissertações da CAPES, da USP e da UNICAMP $^{2}$. Nos campos de buscas das três bibliotecas digitais procuramos pelo termo professor iniciante e encontramos um total de 20 trabalhos, distribuídos como representa o quadro abaixo:

\footnotetext{
${ }^{1}$ Utilizaremos a primeira pessoa do singular, quando houver referência à professora ou aluna do programa de ELLTF e a primeira pessoa do plural quando se trata da pesquisadora.

2 Pesquisa realizada em agosto de 2014 nos endereços da CAPES: http://bancodeteses.capes.gov.br/, da USP: http://www.teses.usp.br/ e da UNICAMP: http://www.bibliotecadigital.unicamp.br/.
} 


\begin{tabular}{|l|l|}
\hline Biblioteca virtual & Número de trabalhos encontrados \\
\hline CAPES & 14 \\
\hline USP & 4 \\
\hline UNICAMP & 2 \\
\hline
\end{tabular}

Quadro 1: Total de dissertações e teses sobre o professor iniciante.

Após este levantamento de dados, procuramos identificar se essas pesquisas tiveram como objetivo estudar o professor iniciante ou se apenas usavam o termo sem ser o objeto principal de sua pesquisa. Para isso, examinamos os resumos dos 20 trabalhos e verificamos que 14 deles centraram suas pesquisas no professor que estava em seus primeiros anos de atividade. Em seguida, fizemos uma análise um pouco mais detalhada sobre as particularidades desses sujeitos investigados e constatamos que o termo professor iniciante se referiu, basicamente, a dois perfis de professores: os já formados e os alunos de graduação. Encontramos ainda, um trabalho sem distinção entre o professor já formado e o aluno de licenciatura, como podemos ver no quadro abaixo. 


\begin{tabular}{|c|c|c|}
\hline \multicolumn{2}{|r|}{ Dissertação ou tese } & \multirow{2}{*}{$\begin{array}{l}\text { Perfil do professor estudado } \\
\text { Professor graduado, nos } \\
\text { primeiros anos de carreira }\end{array}$} \\
\hline 1 & $\begin{array}{l}\text { O processo de socialização e construção de identidade } \\
\text { profissional do professor iniciante de química } \\
\text { Elaine Gomes Matheus Furlan }\end{array}$ & \\
\hline 2 & $\begin{array}{l}\text { Perspectivas e estilos do professor experiente } \\
\text { e iniciante na formação inicial: questões teórico- } \\
\text { metodológicas } \\
\text { Katia Diolina Freire }\end{array}$ & Aluno de licenciatura \\
\hline 3 & $\begin{array}{l}\text { Inclusão nas aulas de educação física: reflexões a partir } \\
\text { da prática pedagógica de um professor iniciante } \\
\text { Thiago Medeiros Gonçalves Pinto }\end{array}$ & $\begin{array}{l}\text { Professor graduado, nos } \\
\text { primeiros anos de carreira }\end{array}$ \\
\hline 4 & $\begin{array}{l}\text { A investigação sobre a própria prática de } \\
\text { um professor iniciante sob o olhar da teoria da } \\
\text { recontextualização } \\
\text { Bruno Marques dos Santos }\end{array}$ & $\begin{array}{l}\text { Professor graduado, nos } \\
\text { primeiros anos de carreira }\end{array}$ \\
\hline 5 & $\begin{array}{l}\text { Indícios do conhecimento pedagógico do conteúdo de } \\
\text { licenciandos em química durante o estágio } \\
\text { supervisionado } \\
\text { Perceli Gomes Elias }\end{array}$ & Aluno de licenciatura \\
\hline 6 & $\begin{array}{l}\text { Professoras iniciantes bem-sucedidas: um estudo sobre } \\
\text { seu desenvolvimento profissional } \\
\text { Silmara de Oliveira Gomes Papi }\end{array}$ & $\begin{array}{l}\text { Professor graduado, nos } \\
\text { primeiros anos de carreira }\end{array}$ \\
\hline 7 & $\begin{array}{l}\text { Construindo saberes a partir do exercício da docência: } \\
\text { o processo de aprendizagem do professor iniciante de } \\
\text { educação física } \\
\text { Amanda Luiza Aceituno da Costa }\end{array}$ & $\begin{array}{l}\text { Professor graduado, nos } \\
\text { primeiros anos de carreira }\end{array}$ \\
\hline 8 & $\begin{array}{l}\text { O professor de educação física: análise dos primeiros } \\
\text { anos de carreira na docência } \\
\text { Tania Clarice Silva de Souza }\end{array}$ & $\begin{array}{l}\text { Professor graduado, nos } \\
\text { primeiros anos de carreira }\end{array}$ \\
\hline 9 & $\begin{array}{l}\text { A prática dos professores recém-graduados e a sua } \\
\text { formação permanente } \\
\text { Camila Zanella }\end{array}$ & $\begin{array}{l}\text { Professor graduado, nos } \\
\text { primeiros anos de carreira }\end{array}$ \\
\hline 10 & $\begin{array}{l}\text { Saberes de professores tutores iniciantes: a educação a } \\
\text { distância no ensino superior de uma instituição privada } \\
\text { de santa catarina em análise } \\
\text { Sirlene Aparecida Fabris }\end{array}$ & $\begin{array}{l}\text { Professor tutor graduado, nos } \\
\text { primeiros anos de carreira }\end{array}$ \\
\hline 11 & $\begin{array}{l}\text { Como os jogos podem revelar outras dimensões do } \\
\text { trabalho do professor de língua estrangeira? } \\
\text { Simone Maria Dantas Longhi }\end{array}$ & $\begin{array}{l}\text { Professor graduado, nos } \\
\text { primeiros anos de carreira }\end{array}$ \\
\hline 12 & $\begin{array}{l}\text { A escola pública, o trabalho docente e os professores } \\
\text { iniciantes } \\
\text { Regina Celia Pereira Baptista dos Santos }\end{array}$ & $\begin{array}{l}\text { Aluno de licenciatura e } \\
\text { Professor graduado, nos } \\
\text { primeiros anos de carreira }\end{array}$ \\
\hline 13 & $\begin{array}{l}\text { Tecendo os fios do início da docência: a constituição da } \\
\text { professora iniciante } \\
\text { Marciene Aparecida Santos Reis }\end{array}$ & $\begin{array}{l}\text { Professor graduado, nos } \\
\text { primeiros anos de carreira }\end{array}$ \\
\hline 14 & $\begin{array}{l}\text { Como foi começar a ensinar? Histórias de professoras, } \\
\text { histórias da profissão docente } \\
\text { Daniela Dias dos Anjos }\end{array}$ & $\begin{array}{l}\text { Professor graduado, nos } \\
\text { primeiros anos de carreira }\end{array}$ \\
\hline
\end{tabular}

Quadro 2: O perfil do professor iniciante em dissertações e teses.

A partir deste levantamento, percebemos que 11 trabalhos se propuseram a investigar o trabalho do professor já formado em seus primeiros anos de atividade, como pretendemos neste estudo; dentre esses trabalhos, verificamos, ainda, que a pesquisa 
"Como os jogos podem revelar outras dimensões do trabalho do professor de língua estrangeira?", de Dantas-Longhi (2013) é a única que estuda o trabalho do professor iniciante de língua estrangeira (LE), mais especificamente, o professor de FLE. Justamente, esse estudo foi desenvolvido em nosso grupo de pesquisa ALTER-AGE, que, recentemente, apresentou outros avanços nos estudos sobre esse tipo de professor, com Menezes (2015) e SILVA (2015).

Diante desse conjunto de trabalhos sobre o professor iniciante e da lacuna deixada por ele no que se refere ao professor iniciante de LE e de FLE, esperamos contribuir com os atuais e futuros estudos sobre esse assunto, assim como colaborar com os trabalhos já desenvolvidos pelo grupo ALTER-AGE. Porém, a particularidade de nosso estudo é o método que usamos para realizá-lo, assim como a metodologia de geração de dados, como veremos mais à frente.

Para justificar a importância do estudo do professor iniciante, apoiamo-nos em Saujat (2004b) que investiga o trabalho do professor no início de carreira. O pesquisador focaliza o agir do professor em situação de trabalho, observando os recursos usados por ele para superar as barreiras representadas pela falta de experiência profissional. Sua investigação visa a ampliar os conhecimentos sobre o métier ${ }^{3}$ de professor já que, de acordo com Saujat (2004b), a análise da atividade do professor iniciante mostra a falta de "formas estáveis", isto é: modos de agir que são reconhecidos pelo meio profissional de trabalho e difundidos na profissão (FAÏTA, 2004).

Diante dos obstáculos ligados à falta de experiência, Saujat (2004b) aponta que o professor iniciante busca compensar suas dificuldades provisórias para resolver os problemas com recursos intermediários, como por exemplo, usando técnicas de controle da sala de aula. Nesse sentido, o professor se preocupa com um ambiente em que seja possível a aprendizagem não somente de seus alunos, mas também sua própria aprendizagem.

Sabendo que o professor iniciante pode ser considerado em algumas pesquisas como aluno de licenciatura e em outras como já licenciado, é preciso dizer que nesta pesquisa, tratamos por professor iniciante aquele que já tem formação e está em seus primeiros anos como docente. Para determinar o perfil do professor de nosso contexto de estudo, consideramos os estudos de Huberman (1992) que propõe delimitar as fases do

\footnotetext{
${ }^{3}$ Decidimos manter o termo métier ao invés de traduzi-lo como ofício, para manter seu sentido. Nesta pesquisa, métier está relacionado ao trabalho específico do professor.
} 
ciclo de vida profissional dos professores. O autor apresenta uma sequência de fases do desenvolvimento da carreira do professor determinada pelos anos de atividade. Como mostra o quadro abaixo (HUBERMAN, 1992, p.47):

\begin{tabular}{|l|l|}
\hline \multicolumn{1}{|c|}{ Anos de Carreira } & \multicolumn{1}{c|}{ Fases/Temas da carreira docente } \\
\hline $1-3$ & Entrada na carreira \\
\hline $4-6$ & Estabilização na carreira \\
\hline $7-25$ & Diversificação e questionamento \\
\hline $25-35$ & Serenidade, distanciamento afetivo e conservantismo \\
\hline $35-40$ & Desinvestimento \\
\hline
\end{tabular}

Segundo Huberman (1992), essas fases devem ser compreendidas como "tendências gerais" do ciclo de vida do professor, ou seja, não representam um quadro fechado das etapas percorridas por ele, pois o desenvolvimento da carreira docente é particular. Assim, o autor explica que as fases podem ser vividas de maneiras diferentes, enquanto um professor pode viver todas as fases, por exemplo, outro pode não viver todas elas ou ainda passar vários anos em uma única fase.

Como temos a intenção de compreender o trabalho do docente em seus primeiros anos de atividade, concentramo-nos na primeira fase proposta por Huberman (1992) - a da entrada na carreira docente ${ }^{4}$. De acordo com autor, o início da carreira do professor alcança os três primeiros anos de atividade docente, essa etapa é chamada, vulgarmente, “choque do real”. Huberman (1992) esclarece que, durante esse período, o professor está na fase da descoberta e da sobrevivência, sendo assim, ele divide as características da profissão, nessa fase, da seguinte maneira (1992, p.39):

- Aspectos da descoberta - O entusiasmo inicial: satisfação por ter responsabilidades profissionais (sala de aula, alunos, programas etc.); satisfação por pertencer a um grupo profissional - o corpo docente; etc.

- Aspectos da sobrevivência - O tatear constante: a preocupação consigo próprio; distância entre as expectativas e a realidade; dificuldade com os alunos que criam problemas; dificuldade com o material didático inadequado; etc.

Conforme Huberman (1992), a descoberta e a sobrevivência, na fase da entrada na carreira docente, vivem paralelamente. No entanto, é possível, também, uma sobrepor

\footnotetext{
${ }^{4}$ A professora participante desta pesquisa começou a ensinar FLE em meados de 2010 e este estudo iniciouse em 2013. Sendo assim, no momento da pesquisa, ela estava completando o terceiro ano de experiência docente. Isso lhe aproxima mais da fase de Entrada na carreira, de acordo com Huberman (1992).
} 
a outra, ou ainda, encontrar perfis com a existência apenas de um desses componentes. Por isso, para contemplar os diferentes perfis existentes nessa fase, o autor propõe o termo de "exploração" que engloba os aspectos de descoberta e sobrevivência.

Após essa explanação sobre o nosso objeto de estudo, ou seja, o trabalho do professor iniciante de FLE, passamos para o histórico da pesquisa e seu contexto, no qual apresentamos a professora participante da pesquisa e sua situação de trabalho.

\section{Histórico e contextualização da pesquisa}

A presente pesquisa nasceu de uma indagação que se manifestou quando me tornei professora de francês: como ensinar uma língua estrangeira? Essa inquietação surgiu por volta de 2010, ano seguinte a minha conclusão da graduação em Letras português-francês na Faculdade de Ciências e Letras da Universidade Estadual Paulista "Júlio de Mesquita Filho" (UNESP). A formação teórica e o estágio prático desenvolvidos na faculdade não foram suficientes para saber o que e como fazer em sala de aula. As dificuldades foram ainda maiores, quando comecei a trabalhar com o ensino de francês em centros de línguas da rede pública e privada ${ }^{5}$, onde havia poucos documentos de orientação para o professor e ausência de um coletivo de trabalho, ou seja, nenhum colega, também professor de francês, com quem discutir.

Diante dessas dificuldades, em 2011 decidi prosseguir os estudos inscrevendo-me como aluna especial na disciplina de "Metodologia de Pesquisa em Didática e EnsinoAprendizagem de Línguas Estrangeiras", oferecida pelo programa de Estudos Linguísticos, Literários e Tradutológicos em Francês da FFLCH na USP. Nessa disciplina, tive a oportunidade de entrar em contato com a esfera da pesquisa acadêmica e desenvolver um pré-projeto, sob orientação da atual orientadora desta pesquisa. Como meu interesse era aprender a ensinar, elaborei esse pré-projeto pensando em questões ligadas ao trabalho do professor iniciante de FLE, assim, após algumas modificações, ele foi utilizado no processo de seleção para o ingresso no Mestrado em 2013.

Logo no início do curso de Mestrado passei a frequentar as reuniões do grupo de pesquisa ALTER-AGE, onde conheci as participantes destas pesquisas: Mariana,

\footnotetext{
${ }^{5}$ Trabalhei entre 2011 e 2012 em dois projetos de ensino de línguas: no CEL (Centro de Estudo de Línguas), da Secretaria da Educação do Estado de São Paulo e no Instituto Nossa Senhora do Sagrado Coração Colégio Preve Objetivo.
} 
professora iniciante de FLE e aluna de Mestrado, e Flávia, também professora de FLE, com mais experiência e cursando o Doutorado. Eu e Mariana nos deparamos com inquietações muito parecidas, sobretudo questões ligadas ao trabalho do professor iniciante, pois encontrávamo-nos na mesma situação: vivenciando os primeiros anos de atividade, após a licenciatura, e aprendendo a ser professoras de uma LE. Além disso, estávamos no processo de melhor definir as etapas e procedimentos de nossas pesquisas de Mestrado. Então, com auxílio de nossa orientadora, decidimos propor duas pesquisas que tivessem como objeto de estudo o trabalho do professor iniciante de FLE. Assim, reunimo-nos com Flávia, que poderia nos ajudar, já que ela estava estudando questões ligadas ao trabalho educacional em sua pesquisa de Doutorado. Como eu e Mariana trabalhávamos em contextos diferentes, pensamos ser interessante estudar as preocupações, os obstáculos, os problemas enfrentados pela outra professora iniciante, observando a influência de seu contexto em sua atividade. Surgiram, então, dois projetos de pesquisas de Mestrado (a presente pesquisa e a de Mariana), que nasceram a partir da constituição de um pequeno coletivo (com três professoras de FLE) desenvolvido em um núcleo de pesquisa.

Para desenvolver nossas pesquisas, nós optamos por utilizar o método de entrevista chamado instrução ao sósia (IS), pois nossas aulas não seriam filmadas, não trazendo tanta exposição para nós duas, que estávamos iniciando a carreira docente, assim ficamos mais confortáveis com a opção de a entrevista de IS ser registrada somente em áudio e posteriormente transcrita. Além disso, nós três morávamos em cidades diferentes e nos encontrávamos na USP durante as reuniões do grupo de pesquisa ou em algumas atividades relacionadas ao curso de pós-graduação, como aulas e eventos, sendo assim, era possível nesses encontros gravarmos as entrevistas.

O método de IS ${ }^{6}$ é desenvolvido pela Clínica da Atividade (CLOT, 1999; 2001) e composto por duas etapas: i) entrevista gravada em áudio, em que o professor, considerando uma substituição hipotética em seu trabalho pelo seu sósia, deve instruí-lo sobre o que é preciso ser feito para que ninguém perceba a substituição; ii) retorno à IS, discussão, também gravada em áudio, realizada após a transcrição da IS com comentários do professor por escrito. Nesse procedimento, eu e Mariana fomos as professoras instrutoras e Flávia desempenhou o papel de sósia.

\footnotetext{
${ }^{6} \mathrm{O}$ método de instrução ao sósia será apresentado com mais detalhes no capítulo dos pressupostos teóricos.
} 
Pareceu-nos importante, naquele momento, estabelecer que nossas análises se dariam de forma cruzada, propiciando que cada uma pudesse investigar o trabalho da outra. Essa decisão foi pautada por preocupações de ordem teórico-metodológica, já que nos apoiamos em linhas que valorizam o papel da intervenção de uma pessoa externa na situação de trabalho, para, posteriormente, utilização desses dados para pesquisa pelas pessoas envolvidas na intervenção, mas não na situação de trabalho. Assim, as duas pesquisas contaram com uma geração única de dados a partir de dois contextos de trabalhos diferentes (o meu e o de Mariana), porém cada uma de nós centrou sua análise nos dados da outra professora. Desse modo, eu analisei os dados do contexto de trabalho de Mariana, que por sua vez, analisou o meu contexto de trabalho.

Sendo assim, nossa pesquisa está centrada no trabalho de Mariana, professora iniciante de FLE que teve e ainda tem sua formação acadêmica e profissional associada a uma mesma universidade, a USP. Mariana é bacharela em Letras, com habilitação em português e francês, e, no momento da pesquisa, cursava licenciatura em Letras, o curso Mestrado no programa de Estudos Linguísticos, Literários e Tradutológicos em Francês e trabalhava nos cursos Extracurriculares de francês. A respeito de seu contexto de trabalho, sabemos que os cursos são oferecidos pelo Serviço de Cultura e Extensão Universitária $^{7}$ da FFLCH - USP, que respondem, segundo Dantas-Longhi (2013), à duas demandas principais: a primeira, de oferecer aulas de língua estrangeira (LE) à comunidade interna e externa à USP como forma de devolver à sociedade os investimentos feitos na universidade pública e, a segunda, de oferecer experiência prática e formação continuada em ensino de LE aos alunos ${ }^{8}$ de licenciatura ou pós-graduação da USP, servindo também como espaço para suas pesquisas em ensino-aprendizagem de LE. Sendo assim, não podemos deixar de destacar a importância desta pesquisa em investigar o trabalho de uma professora inserida em um contexto público, que lhe dá suporte para estudar, aprender seu trabalho e pesquisar.

\footnotetext{
${ }^{7}$ http://sce.fflch.usp.br/ (acesso em 26/01/2016).

${ }^{8}$ Veremos no capítulo de metodologia que, para ser um monitor dos cursos Extracurriculares, é preciso ter vínculo como aluno na USP.
} 


\section{O grupo ALTER-AGE e quadro teórico-metodológico adotado}

Nosso estudo insere-se no grupo de pesquisa ALTER-AGE ${ }^{9}$ do $\mathrm{CNPq}$, que está articulado em três vertentes de estudo: a da didática das línguas materna e estrangeira, a dos gêneros textuais no processo de ensino-aprendizagem e a do trabalho educacional ${ }^{10}$. Desse modo, nossa pesquisa dialoga com outras desse grupo (GUIMARAES-SANTOS, 2012; MELAO, 2014; ANEZ-OLIVEIRA; 2014; ROCHA, 2014), sobretudo com aquelas que abordam o trabalho educacional (DANTAS-LONGHI, 2013; SILVA, 2015; MENEZES, 2015).

Coordenado pelas pesquisadoras Eliane Gouvêa Lousada (USP) e Luzia Bueno (USF), o grupo ALTER-AGE foi criado em 2011 e é formado atualmente por pesquisadores, alunos de Doutorado, Mestrado e Iniciação Científica, com pesquisas embasadas em duas vertentes do interacionismo social (VYGOTSKI, 1927-2009), a saber: o interacionismo sociodiscursivo (BRONCKART, 1999/2009, 2006, 2008) e as Ciências do Trabalho, mais especificamente Clínica da Atividade (CLOT, 1999, 2001, 2007) e Ergonomia da Atividade dos Profissionais da Educação (AMIGUES, 2004, SAUJAT, 2004, FAÏTA, 2004).

O ALTER-AGE nasceu do grupo de pesquisa Análise de Linguagem, Trabalho Educacional e suas Relações (ALTER) do Programa de Estudos Pós-Graduados em Linguística Aplicada e Estudos da Linguagem da Pontifícia Universidade Católica de São Paulo, fundado em 2002 por Anna Rachel Machado. A pesquisadora introduziu e disseminou no Brasil estudos com base no interacionismo sociodiscursivo (ISD), fundado por Bronckart (1999, 2006, 2008), a partir das relações desenvolvidas com esse autor e com o grupo que coordena: Langage, Action et Formation ${ }^{11}$ (LAF) de Genebra na Suíça.

Um marco do ISD no Brasil foi a publicação da tradução feita por Machado da obra de Bronckart (1997) "Atividade de linguagem, textos, discurso: por um interacionismo sociodiscursivo", publicada em 1999. Cinco anos depois, a coletânea de textos organizada pela mesma autora e intitulada de "O ensino como trabalho: uma abordagem discursiva" foi referência para pesquisas do Grupo ALTER/LAEL, voltadas para os estudos do ISD interligados ao ensino como trabalho, reunindo pesquisadores dos

\footnotetext{
${ }^{9}$ Análise de Linguagem, Trabalho e suas Relações - Aprendizagem, Gêneros Textuais e Ensino.

${ }^{10}$ Para maiores informações: http://dlm.fflch.usp.br/frances/ALTER-AGE (acesso em 14/11/2015).

${ }^{11}$ Linguagem - Ação - Formação.
} 
grupos ALTER/LAEL e ATELIER, do Brasil, e ERGAPE e LAF, da França e Suíça, respectivamente.

Sendo assim, o ISD permite uma aproximação com outras linhas teóricas, como a Ergonomia da Atividade e a Clínica da Atividade. Nesse sentido, os trabalhos desenvolvidos no Grupo ALTER/LAEL têm estreita relação com mais outros dois grupos estrangeiros: o grupo ERGAPE ${ }^{12}$ da Ergonomia da Atividade francesa (AMIGUES, 2004; SAUJAT, 2004; FAÏTA, 2004), com sede no Institut de Formation de Maîtres (IUFM) em Marselha, onde desenvolve pesquisas relacionadas ao trabalho educacional; e o grupo do CNAM $^{13}$, da Clínica da Atividade, coordenado por Clot $(1999,2001)$ em Paris, que se propõe a estudar o trabalho (não apenas o educacional) e o trabalhador pela observação que o próprio trabalhador faz de sua atividade.

Os pesquisadores desses dois grupos buscam, por meio de métodos indiretos, compreender o trabalho em sua totalidade, estudando a organização do trabalho através da análise da atividade, pelo ponto de vista do trabalho e do trabalhador. Isso significa que esses pesquisadores levam em conta o agir dos professores e os elementos das situações reais de trabalho (AMIGUES, 2003; FAÏTA \& SAUJAT, 2010; CLOT, 2001).

Dessa forma, conforme algumas pesquisas do grupo ALTER/LAEL (ABREUTARDELLI, 2006; LOUSADA, 2006; MACHADO et al. 2009; BARRICELLI, 2012), nesta pesquisa também procuramos reunir os pressupostos teórico-metodológicos do Interacionismo Sociodiscursivo (ISD) aos da Ergonomia da Atividade e da Clínica da Atividade.

Ao lado de alguns estudiosos do trabalho (BRONCKART, 2004c; AMIGUES, 2004; FAÏTA, 2004; SAUJAT, 2004), consideramos a atividade de ensino como um trabalho. Nesse sentido, Amigues (2002, 2003, 2004) mostra que o ensino é apenas uma parte do trabalho do professor. Isso significa que também estão ligadas ao seu trabalho outras atividades como a preparação de aulas, reelaboração e execução de tarefas prescritas pela instituição de ensino, participação em reuniões pedagógicas ou em cursos de formação continuada de professores etc. Dessa forma, o professor não se relaciona somente com alunos (AMIGUES, 2003, 2004; SAUJAT, 2003, 2004), mas com funcionários do local de ensino (coordenador, diretor, professores, outros profissionais não necessariamente ligados ao ensino etc.) ou ainda com pessoas fora do contexto de

\footnotetext{
${ }^{12}$ Ergonomie de l'Activité des Professionnels de l'Education.

${ }^{13}$ Conservatoire des Arts et Métiers.
} 
trabalho como pais de alunos, por exemplo.

A partir dessa reflexão, acreditamos que, para compreender o trabalho do professor, é preciso considerar sua totalidade, não apenas sua atividade em sala de aula. Com base nisso, Amigues (2002) explica que a relação entre professor e aluno não se faz de modo direto e imediato, porém mediada pelas prescrições. Para o autor é difícil pensar na aprendizagem dos alunos desconsiderando, por exemplo, a organização do programa desenvolvido ou adotado, aquilo que foi elaborado pelas instâncias governamentais ou escolares para regular o trabalho do professor. Sendo assim, a prescrição é compreendida como um conjunto de obrigações, ordens, regras elaboradas por uma hierarquia que indica o que o trabalhador deve fazer (AMIGUES, 2004; BERTHET e CRU, 2003; DANIELLOU, 2000). Para melhor definir as prescrições, baseamo-nos nos estudos de Barricelli (2012), que, apoiada em estudos sobre o trabalho (AMIGUES, 2004), apresenta as prescrições como explícitas e implícitas, definindo as prescrições explícitas como as normas efetivamente declaradas e as prescrições implícitas como as regras que pertencem ao plano do subentendido.

Se pensarmos em documentos que prescrevem o trabalho do professor no âmbito nacional, podemos lembrar-nos dos Parâmetros Curriculares Nacionais (PCN). Já para um professor de língua estrangeira, temos o Cadre Européen Commun de Référence $(\mathrm{CECR})^{14}$. No entanto, tanto as orientações dos PCN, quanto as do CECR, como a de outros textos prescritivos, apresentam prescrições vagas (AMIGUES, 2003), assim, dizem o que o professor deve fazer, mas sem dizer como fazer (LOUSADA, 2011). É por esse motivo, que os professores, individualmente e no coletivo de trabalho, precisam redefinir e adaptar sua tarefa às situações de trabalho (DAGUZON e GOIGOUX, 2007; AMIGUES, 2009). Levando em consideração o que acabamos de expor, neste trabalho, nós analisamos o documento de orientação do contexto de trabalho de Mariana, o Guide du Moniteur, que é um documento muito próximo de seu contexto de trabalho.

Ainda buscando compreender o trabalho do professor, consideramos, também, além das prescrições, textos em que o professor diz e/ou escreve sobre o seu trabalho. Sendo assim, optamos pelo uso de dois outros instrumentos: as entrevistas de instrução ao sósia (IS) e os diários de aula.

Utilizamos a IS por se tratar de um método indireto (VYGOTSKI, 1927/1999),

\footnotetext{
${ }^{14}$ Quadro Europeu Comum de Referência (QECR).
} 
visto que a atividade vivenciada não é diretamente acessível, ou seja, não é possível compreendê-la através de métodos diretos, como, por exemplo, apenas por meio da observação do trabalho realizado. Com essa premissa, utilizamos um dos métodos indiretos, com base vigotskiana, desenvolvido por pesquisadores da Clínica da Atividade e da Ergonomia da Atividade (CLOT, 2001b; AMIGUES, 2004; SAUJAT, 2004, 2005).

Também analisamos em nosso estudo quatro diários de aulas produzidos pela participante de nossa pesquisa - Mariana - escritos após suas aulas, relatando suas impressões e experiências vivenciadas em seu contexto de trabalho. Consideramos, ao lado de Schneuwly (1994) e Machado (1998), o gênero diário de aula como instrumento que permite a reflexão, em nosso caso, sobre o trabalho de ensino e, por isso, optamos por utilizá-lo também, combinando-o com o método da IS

Os dados coletados nesta pesquisa, o Guide du Moniteur, e os dados gerados por nós (as instruções ao sósia e os diários de aulas) foram analisados com base no quadro teórico-metodológico do interacionismo sociodiscursivo (ISD) apresentado por Bronckart (1999, 2006, 2008) e desenvolvido por pesquisadores brasileiros como Machado (2004), Lousada (2006, 2010), Abreu-Tardelli (2006), entre outros. O ISD foi utilizado como embasamento teórico para a análise dos textos e para a compreensão do trabalho do professor iniciante do ponto de vista do agir docente. Também baseamo-nos nos conceitos oriundos de duas ciências que estudam o trabalho: a Ergonomia da Atividade (AMIGUES, 2002, 2004, 2012; SAUJAT, 2004; AMIGUES et al. 2014) e a Clínica da Atividade (CLOT, 1999; 2001; 2006), que forneceram meios para compreender as situações e os dilemas encontrados pelos professores iniciantes em situação de trabalho. Além disso, nós nos servimos também de algumas contribuições dadas por outros autores, sobretudo no que concerne ao enriquecimento da análise dos textos, como Authier-Revuz (1998), Maingueneau (2011) e Bulea (2010).

\section{Perguntas de pesquisa}

Como exposto anteriormente, nossa pesquisa tem por objetivo geral compreender o trabalho do professor iniciante de FLE no contexto dos cursos Extracurriculares de francês da FFLCH-USP, mais precisamente, pretendemos: i) estudar o papel das prescrições/orientações no trabalho desse professor, procurando investigar como elas afetam seu trabalho e ii) estudar a atividade do professor a partir do que ele diz sobre seu 
próprio trabalho e sobre si mesmo enquanto professor. Para atender nossos objetivos, nós nos orientamos por três questões:

\begin{tabular}{|l|l|}
\hline \multicolumn{1}{|c|}{ Perguntas de pesquisa } & \multicolumn{1}{|c|}{ Objetivos } \\
\hline $\begin{array}{l}\text { 1. Quais são as prescrições no trabalho do } \\
\text { professor iniciante de língua estrangeira } \\
\text { de um curso extracurricular em uma } \\
\text { universidade do Estado de São Paulo? }\end{array}$ & $\begin{array}{l}\text { a) estudar o papel das prescrições no } \\
\text { trabalho do professor iniciante de FLE, } \\
\text { procurando investigar como elas afetam } \\
\text { Qual o seu papel? São explícitas ou } \\
\text { implícitas? }\end{array}$ \\
\hline $\begin{array}{l}\text { 2. Como o professor iniciante concebe } \\
\text { seu trabalhos Quais são as representações } \\
\text { sobre seu trabalho, sobre si enquanto } \\
\text { professor e sobre os participantes da } \\
\text { situação de trabalho? }\end{array}$ & $\begin{array}{l}\text { b) investigar a atividade do professor } \\
\text { iniciante de FLE a partir do que ele diz } \\
\text { sobre seu próprio trabalho e sobre si } \\
\text { mesmo como professor nesse contexto. }\end{array}$ \\
$\begin{array}{l}\text { 3ituação de trabalho em um curso } \\
\text { extracurricular de francês? Quais são as } \\
\text { soluções encontradas pelo professor para } \\
\text { executar seu trabalho nessa situação? }\end{array}$ & \\
\hline
\end{tabular}

Quadro 4: As perguntas e objetivos da pesquisa.

\section{Organização da dissertação}

Para atingir os objetivos acima, esta pesquisa está organizada em cinco capítulos descritos abaixo:

\section{Capítulo I - Pressupostos Teóricos}

Neste capítulo, apresentamos as correntes teóricas que embasam esta pesquisa. Para tanto, dividimos o capítulo em duas seções. Na primeira seção, apresentamos os conceitos e procedimentos metodológicos de duas das linhas teóricas das Ciências do trabalho: a Clínica da Atividade e a Ergonomia da Atividade que se dedicam às questões sobre o trabalho e o trabalho do professor, respectivamente. Na segunda seção, explanamos o quadro teórico-metodológico do interacionismo sociodiscursivo (ISD) que nos forneceu apoio tanto para refletir sobre questões ligadas ao trabalho do professor como uma forma de agir humano, quanto para analisar os textos desta pesquisa. 


\section{Capítulo II - Metodologia de Pesquisa}

No capítulo sobre a metodologia de pesquisa, descrevemos o percurso deste trabalho. Assim, iniciamos com a apresentação do contexto de pesquisa que abrange o local e os participantes envolvidos; em seguida, apresentamos as etapas da coleta e geração de dados, para posteriormente, expormos os procedimentos de seleção dos dados e o modo como os analisamos.

\section{Capítulo III - Resultados das análises}

Visamos a apresentar, neste capítulo, os resultados obtidos pelas análises dos dados coletados e produzidos. Para isso, dividimos o capítulo em três seções. Na primeira seção, centramo-nos nos resultados da análise do documento que orienta o trabalho da professora participante, o Guide du Moniteur. Na segunda seção, trabalhamos com os resultados das análises dos diários de aula produzidos por essa professora. E na terceira seção, dedicamo-nos aos resultados da análise das duas entrevistas de Instrução ao Sósia e seus retornos.

\section{Capítulo IV - Discussão dos Resultados}

Nesse capítulo, apresentamos uma discussão dos resultados obtidos pelas análises dos dados. Propomos relacionar essas análises com as questões da pesquisa, sintetizando os resultados e apresentando nossas interpretações.

\section{Considerações Finais}

Propomos uma breve recuperação dos conteúdos já abordados, relacionando-os com os resultados e os objetivos da pesquisa. Além disso, apontaremos possíveis melhorias ou alternativas para o estudo realizado, assim como as contribuições que ele pode trazer para a teoria utilizada, para professores de FLE e outros estudos. 


\section{CAPÍTULO I- FUNDAMENTAÇÃO TEÓRICA}

Buscamos, nesta pesquisa, compreender o trabalho do professor, mais precisamente, do professor iniciante em ensino de FLE. Para realizar esse estudo, apoiamo-nos em duas vertentes teóricas que nos forneceram suporte para a geração e análise de dados: por um lado, o interacionismo sociodiscursivo (Bronckart, 1999/2009, 2008); por outro lado, os estudos da Clínica da atividade (Clot, 1999) e Ergonomia da atividade (Amigues, 2004, Saujat, 2004, Faïta, 2004). A adoção dessas duas linhas justifica-se pelo fato de serem vertentes de uma mesma posição epistemológica e filosófica: o interacionismo social.

Dessa forma, os conceitos e métodos trabalhados neste capítulo são frutos de pesquisas ligadas ao interacionismo social tal como desenvolvido por Vygotski (1934/1997), psicólogo que teve como um dos objetivos estudar e compreender o desenvolvimento humano, verificando as relações entre pensamento e linguagem.

Bronckart (1999/2009) define o interacionismo social como uma "posição epistemológica geral", na qual várias correntes das ciências humanas e da filosofia se baseiam. Essas correntes têm em comum a tese de que "as propriedades específicas das condutas humanas são o resultado de um processo histórico de socialização, possibilitado especialmente pela emergência e pelo desenvolvimento dos instrumentos semióticos." (BRONCKART, 1999/2009, p.21, grifos do autor). Com base nesse conceito, entendemos que o desenvolvimento humano é indissociável dos processos de socialização e individuação.

O interacionismo social proposto por Vygotski fornece-nos base para compreender o desenvolvimento do trabalho do professor, no entanto, precisamos levar em consideração a distância entre a época desses estudos e o contexto atual no qual se insere o professor que pretendemos estudar. Diante disso, levamos em conta uma questão importante: Como empregarmos os conceitos de Vygotski, que foram desenvolvidos em determinada época, para compreendê-los hoje?

Janette Friedrich (2010) encaminha-nos para uma resposta: a autora deixa claro que tem como objetivo, não somente reproduzir as ideias de Vygotski, mas pensar a partir do que ele diz, levando em conta os problemas atuais. Assim, diante de muitas obras que procuram transmitir os conceitos de Vygotski, temos interesse naquelas que procuram revisitar as obras de Vygotski procurando interpretá-las para o contexto atual, sobretudo 
no que se refere à educação e formação, enfatizando, principalmente, o trabalho do professor. Assim, nós nos baseamos em duas linhas teóricas que estão preocupadas com essas questões: o interacionismo sociodiscursivo (BRONCKART, 1999/2009, 2006, 2008) e as ciências do trabalho, mais precisamente, a ergonomia da atividade (AMIGUES, 2002; 2004; 2012; SAUJAT, 2004) e a clínica da atividade (CLOT, 1999; 2001; FAÏTA, 2002, 2004). Essas correntes produziram, dentre os estudos realizados, livros cujos títulos já explicitam a preocupação em dialogar com os pensamentos de Vygotski na atualidade, são eles: "Vygotski aujourd'hui" (BRONCKART e SCHNEUWLY, 1985) e "Vygotski maintenant", (CLOT, 2012).

Para apresentarmos o quadro teórico-metodológico maior - o interacionismo social, de Vygotski - interpretado pelas linhas já mencionadas acima, dividimos este capítulo em duas seções. A primeira está voltada para a reflexão e discussão sobre o trabalho partindo de uma visão mais geral para a mais específica: o ensino como trabalho. A partir disso, apresentamos duas das linhas teóricas das ciências do trabalho: a clínica da atividade e a ergonomia da atividade, que buscam analisar, compreender e transformar as situações de trabalho. Essas linhas teóricas propõem alguns procedimentos que possibilitam a criação de diálogos sobre a atividade de trabalho.

A segunda seção é composta pelo quadro teórico-metodológico do interacionismo sociodiscursivo (ISD), proposto por Bronckart (1999/2009, 2006, 2008). Focaliza-se o estudo da linguagem, já que para Bronckart (1999/2009), ela é papel fundamental no desenvolvimento humano. Desse modo, ele propõe um modelo de análise, para estudar as ações de linguagem materializadas em textos produzidos em determinado contexto sociocultural com o objetivo de compreender o desenvolvimento humano. Com isso, o ISD fornece-nos apoio tanto para refletir sobre questões ligadas ao trabalho do professor quanto para analisar os textos presentes em seu contexto de trabalho. Nós nos servimos também de algumas contribuições dadas por outros autores, sobretudo no que concerne ao enriquecimento da análise dos textos, a saber, Authier-Revuz (1998), Maingueneau (2011), Lousada e Dantas-Longhi (2014) e Bulea (2010). Com base nisso, analisamos textos produzidos pelo professor participante da pesquisa, os diários de aula e as entrevistas de instruções ao sósia, além de textos que regulam/orientam o trabalho desse professor, o documento Guide du Moniteur. 


\section{O trabalho humano como atividade consciente}

Analisar o trabalho do professor requer, antes de tudo, pensar na origem das atividades de trabalho, suas formas de organização, assim como a relação homem e trabalho. Nesta seção, pretendemos refletir sobre o trabalho a partir dos estudos de alguns teóricos, como por exemplo, dos filósofos alemães Friedrich Engels (1876/1999) e Karl Marx (1867), que contribuíram significativamente sobre esse tema. Portanto, parece-nos fundamental iniciar esta seção apresentando suas reflexões, retomando seus conceitos até chegarmos aos dias de hoje.

Segundo Konder (1999), Marx, recuperando as ideias de Hegel, afirma que o trabalho funciona como um elemento que estimula o desenvolvimento. Marx destaca, ainda, a importância que se deve dar ao trabalho físico e material, que segundo ele, não fora considerado nos estudos de Hegel. Para Marx (1867), há três elementos que compõem o processo de trabalho:

1) a atividade adequada a um fim, isto é o próprio trabalho;

2) a matéria a que se aplica o trabalho, o objeto de trabalho;

3) os meios de trabalho, o instrumental de trabalho.

Marx (1867) - A Produção de Mais Valia Absoluta ${ }^{15}$

Em conformidade com esse autor, para compreender o trabalho é preciso considerar todos os elementos que o constitui e vê-lo como forma de agir sobre a natureza em determinado contexto.

Em “O Papel do Trabalho na Transformação do Macaco em Homem”, Engels (1876/1999) propõe mostrar como o trabalho tem papel fundamental na evolução do homem. O autor sustenta a tese de que foi o trabalho que criou o homem. Dessa forma, apoiado nos estudos de Darwin, explica como se deu a evolução de uma raça de macacos antropomorfos, muito desenvolvida, em espécie humana, demonstrando a contribuição do trabalho para o distanciamento dessas espécies. Um dos exemplos citados por Engels é a comparação entre a mão primitiva com a mão do homem. A mão, que fora utilizada durante muitos anos para construir abrigos, alimentar-se, defender-se etc., foi aperfeiçoada pelo trabalho, tornando-se, segundo o autor, livre para poder ser cada vez

\footnotetext{
${ }^{15}$ Disponível em: $<$ http://www.dominiopublico.gov.br/download/texto/ma000067.pdf $>$ (acesso em 06/10/2014).
} 
mais hábil. Com isso, a mão deixa de ser simplesmente um "órgão" do trabalho e passa a ser também fruto dele.

O desenvolvimento da mão, de acordo com Engels (1876/1999), colabora para que o homem tenha domínio sobre a natureza, sendo capaz de explorá-la e descobrir nos objetos características até então desconhecidas. O domínio sobre a natureza intensificase, assim como, aumenta as atividades de trabalho, dessa maneira, observa-se a vantagem do trabalho em grupo. Nesse novo contexto, a comunicação é fundamental. É desse modo, que Engels (1876/1999) explica o surgimento da linguagem: a partir do trabalho e pelo trabalho.

Com bases nos estudos marxistas, Konder (1999) explica que o homem, ao dominar a natureza com seu trabalho, consequentemente, conquista sua liberdade. Isso ocorre, pois, diferentemente da atividade dos animais, determinada por seus instintos, a atividade do homem, inclui prever, planejar e organizar suas ações, antes mesmo de cumprir seu trabalho. Sendo assim, os animais não são livres ao trabalhar, já que suas atividades são realizadas para atender as necessidades imediatas de si mesmo e de seus filhotes. Segundo Konder (1999), para Marx, a grande diferença entre o trabalho realizado pelo homem e o realizado pelos animais está ligada à concepção de liberdade.

O neuropsicólogo Luria (1991) também defende a importância do trabalho para o desenvolvimento do homem, ele define a atividade humana como "atividade consciente" e busca explicar as raízes histórico-sociais dessa atividade consciente humana. Para isso, ele compara a atividade consciente do homem com o comportamento dos animais e destaca três traços fundamentais das diferenças entre eles: i) a atividade do homem não está ligada a motivos biológicos; ii) a atividade consciente do homem não é determinada por questões do meio ou experiências individuais e iii) o conhecimento do homem se forma graças à "assimilação da experiência de toda a humanidade" (LURIA, 1991, p.73). Com isso, o autor afirma que, desde bebê, o homem recebe influência do que já se tem formado na história ao longo dos anos, a transmissão desses conhecimentos se dá por meio da fala, em seguida, é na escola que se aprende as aquisições importantes da humanidade por meio da linguagem.

Várias pesquisas tentaram explicar esses traços da atividade consciente apresentados acima, mas de acordo com Luria (1991), é a psicologia científica, apoiada nos trabalhos de Marx, que aponta que “(...) as raízes do surgimento da atividade consciente do homem não devem ser procuradas nas peculiaridades da 'alma' nem no 
íntimo do organismo humano mas nas condições sociais de vida historicamente formadas." (LURIA, 1991, p.75, formatação do autor). A partir dessa afirmação, Luria (1991) diz que, ao observarmos o que tem de específico na forma histórico-social do homem, deparamo-nos "com o trabalho social, com o emprego de instrumentos de trabalho e com o surgimento da linguagem". Esses fatores são a fonte de mudança da história natural dos animais para a história social dos homens.

A respeito dos instrumentos, diferentemente dos animais, o homem, além de adotar os instrumentos de trabalho, fabrica-os. Segundo Luria (1991), o ato de produzir instrumentos mostra que a atividade do homem não está ligada aos seus instintos ou fatores biológicos imediatos (alimentação, por exemplo), ao contrário, sua fabricação revela que o homem pode planejar e organizar suas ações, estimulando o desenvolvimento da consciência. Luria (1991, p.76) acrescenta, ainda, que a preparação do instrumento de trabalho é a "primeira forma de atividade consciente".

Outro fator que colabora para a atividade consciente humana é o surgimento da linguagem. Luria (1991) define a linguagem como "um sistema de códigos por meio dos quais são designados os objetos do mundo exterior, suas ações, qualidades, relações entre eles, etc.” (1991, p.78). Há várias hipóteses sobre o surgimento da linguagem, mas é a filosofia e a ciência que solucionam cientificamente sua origem. Assim, conforme Luria (1991, p.79, destaques do autor).

\footnotetext{
a solução científica do problema da origem da linguagem só se tornou possível quando a filosofia e a ciência abandonaram as tentativas de procurar as raízes da linguagem no âmago do organismo e de deduzi-la diretamente das peculiaridades do "espírito" ou do cérebro, concluindo que as condições que originaram o fenômeno devem ser procuradas nas relações sociais do trabalho cujos primórdios de surgimento remontam ao período de transição da história natural à história humana.
}

Com isso, apesar da falta de métodos para observar o surgimento da linguagem, muitos fundamentos indicam que ela surgiu das "formas de comunicação contraídas pelos homens no processo de trabalho" (LURIA, 1991, p.79)

$\mathrm{O}$ uso dos instrumentos e da linguagem permitiu que as atividades humanas fossem se modificando e se diversificando conforme o tempo. Bronckart (2008, p.94) explica que as atividades coletivas da espécie humana deixam de ser organizadas com a 
finalidade de garantir a sobrevivência do grupo, assim como outras espécies, e passam a ter como objetivo a produção de bens materiais, sendo chamadas de "atividades econômicas". Essas atividades econômicas estavam ligadas às relações com a família, religião, política etc., portanto nem sempre eram consideradas como trabalho.

Segundo Bronckart (2008), é só no começo do século XVI que surge o termo "trabalho" nas línguas românicas devido à emergência do capitalismo mercantil e, em seguida, industrial. As atividades desenvolvidas, nesse momento, se distanciam daquelas com relações sociais mais restritas e o trabalho passa a ser o meio para se produzir bens. Essa produção é determinada em função dos preços e organizada em "postos de trabalho" oferecidos à população que é remunerada, tornando-se trabalhadores assalariados (BRONCKART, 2008). Konder (1999) explica que esse sistema político-econômico (o capitalismo) é criticado por Marx, que censura o crescimento da valorização do mundo das coisas e consequentemente a desvalorização do mundo dos homens. Konder (1999) acrescenta que, para Marx, nesse sistema de trabalho, o produto (do mundo das coisas) não é produzido de forma livre e criativa, como consequência a atividade passa a ser imposta. Com isso, Marx desenvolve o conceito da "mais-valia", que é gerada pelo trabalho vendido por um preço menor em relação ao trabalho produzido, ou seja, ela é a concretização do tempo de trabalho não pago (KONDER, 1999).

Se transpusermos as reflexões marxistas para o campo educacional, vemos que muitas dessas ideias encontram eco em situações que são vivenciadas no dia-a-dia dos profissionais do ensino. Por exemplo, no âmbito da educação, existe uma crença forte de que o trabalho do professor é desenvolvido apenas em sala de aula, reflexo disso é a associação do salário desse profissional à hora-aula. $\mathrm{O}$ trabalho do professor é desenvolvido na escola, dentro e fora da sala de aula, ele não se limita apenas à escola, mas começa na instituição e termina em casa (ABREU-TARDELLI, 2006).

Embora não diretamente ligadas à nossa pesquisa, cujo o contexto é um curso de extensão de uma universidade pública, essas reflexões são importantes para que compreendamos as vertentes teóricas que adotamos, a ergonomia da atividade e a clínica da atividade, que abordam a situação de trabalho como um todo e a sua relação com o bem-estar dos trabalhadores.

De fato, com a evolução das atividades de trabalho, tornou-se fundamental pensar sobre elas buscando analisar suas formas de organização. Conforme Bronckart (2008), o surgimento da atividade econômico-social colaborou para a emergência da análise das 
formas de organização do trabalho, tais como as regras, as relações hierárquicas, os papeis de cada indivíduo etc. $\mathrm{Na}$ próxima seção, abordaremos os estudos realizados sobre o trabalho, refletindo sobre as pesquisas que contribuíram e contribuem para compreender o trabalho no contexto geral e no mais específico: o trabalho educacional.

\subsection{Os estudos sobre o trabalho e sobre o trabalho educacional}

De acordo com Clot (2007), podemos dizer que as linhas teóricas que embasam nossa pesquisa não partem do nada, pelo contrário, apoiam-se em estudos que nos precedem. Esses estudos permanecem no ideário até hoje, visto a importância de seus autores. No entanto, Clot (2007) lembra que é preciso um olhar lúcido e crítico sobre eles. Neste sentido, apresentaremos nesta seção alguns dos estudos que abordam o trabalho no contexto geral e o trabalho educacional.

As investigações sobre o trabalho foram, inicialmente, realizadas pelos chefes de empresas interessados em aumentar seus lucros. Nesse contexto, um dos nomes importantes para pesquisas de análise do trabalho é do engenheiro Taylor (1856/1915), que se dedicou a estudar as relações de trabalho. Ele fundou o que denominou por Organização Científica do Trabalho, que tinha como objetivo aumentar a produção dos trabalhadores. Desse modo, segundo Bronckart (2008), Taylor colocou em prática seus estudos que consistiam em isolar um operário considerado forte, para que ele não fosse influenciado pelas práticas dos mais fracos, fazendo-o seguir uma lista de instruções fornecidas por um mentor. Sem questionar nada, sua tarefa era cumprir essa lista para que ao final do dia pudesse ser recompensado com $60 \%$ de seu salário diário.

Clot (2007, p.14), embasado nos estudos de Wallon (1932/1976), explica que o taylorismo criou a calibração do gesto, visto que ao invés de deixar o homem agir, afastao de sua atividade ao exigir um "gesto artificial", que lhe causa sofrimento. Usando os termos de Clot (2007, p.200):

Em certo sentido, Taylor não exige demais do trabalhador, mas demasiado pouco. Ao escolher o movimento que exige de sua parte o mínimo de intervenção, priva-se o homem de sua iniciativa. Ora, “amputá-lo de sua iniciativa durante seu dia de trabalho, durante suas oito ou dez horas de trabalho, desemboca no esforço mais dissociativo, mais fatigante e mais extenuante que se possa encontrar". 
No campo da educação, transpondo a ideia de produtividade máxima que é proposta por Taylor, vemos que o taylorismo é usado por instituições escolares que privilegiam a tríade quantidade, rapidez e qualidade e que é encontrado em algumas escolas, faculdades e universidades.

Referência até metade do século XX, Bronckart (2008) aponta que, os estudos baseados no taylorismo, ainda que modificados com o passar do tempo, têm como característica principal adaptar o homem ao seu trabalho, deixando o trabalho no centro das questões e o trabalhador em segundo plano. O autor ainda indica que essas técnicas, utilizadas para aumentar a produção, foram consideradas brutais.

Ao contrário de Taylor, que defende a ideia de que seus métodos atendiam aos interesses dos patrões e dos operários, Laville (2001) aponta que seus princípios favoreciam nitidamente ao patrão, enquanto que o trabalhador, impedido até mesmo de falar (SOUZA-E-SILVA, 2002), tinha sua atividade reduzida à quantidade, rapidez e qualidade.

Neboit (s/d), presidente da Sociedade de Ergonomia de Língua Francesa, explica que a Ergonomia surge justamente como uma oposição ao taylorismo, pois seu objetivo inicial é analisar os problemas enfrentados pelo trabalhador, atentando para sua saúde. Esse mesmo autor data o surgimento do termo "ergonomia" em 1857 a partir de um trabalho intitulado "Précis d'ergonomie ou de la science du travail, basée sur des vérités tirées des sciences de la nature", desenvolvido pelo professor da Universidade de Varsóvia Wojciech Jastrzebowski. O termo é esquecido, pois fora publicado em polonês em uma revista pouco conhecida, sendo reinventado posteriormente, conforme Neboit (s/d), pelo psicólogo inglês Murrel. Desse modo, Bronckart (2008, p.96-97) aponta que Murrel funda essa disciplina em 1949, tendo como finalidade pensar na adaptação do trabalho aos trabalhadores.

De acordo com Neboit (s/d, p.4), a obra "l'Analyse du travail", publicada por Ombredane et Faverge em 1955, contribuiu para o surgimento da ergonomia de língua francesa. Clot e Yvon (2004) afirmam que essa obra sistematizou a análise do trabalho, dando ênfase não apenas à seleção de profissionais e à orientação sobre o trabalho, mas à qualificação do trabalhador, o planejamento do trabalho e à formação profissional.

A ergonomia francesa surgiu após a Segunda Guerra Mundial com o compromisso de reconstruir os países destruídos por ela. Laville (2001) revela-nos que a necessidade 
de aumentar a produtividade do trabalhador ajudou a crescer a preocupação em melhorar as condições de trabalho, então o enfoque é dado às teorias sobre motivação e sobre as necessidades do homem. Assim, a ergonomia de língua francesa se constituiu com a junção de três correntes, as duas primeiras são preocupações muito antigas e a terceira é corrente ligada à evolução da psicologia do trabalho: i) efeitos que o trabalho têm sobre a saúde; ii) preocupação com a eficiência do trabalho humano, sobretudo do trabalho físico; iii) adaptação do homem ao seu trabalho, que, com o tempo, teve como objetivo compreender a realidade do trabalho, buscando adaptar o trabalho ao homem (LAVILLE, 2001, p.1-2).

Apesar da ergonomia francófona ter estudos com enfoque em diferentes aspectos da organização do trabalho, Bronckart (2008, p.97) afirma que ela é centrada principalmente na saúde e na segurança dos trabalhadores, para isso tem como abordagem analisar o trabalho sob o ponto de vista do trabalhador, explorando os problemas reais, presentes em contexto real e tempo real. No entanto, nas diferentes áreas profissionais, poucos são os estudos sobre o trabalhador em conformidade com as situações reais de trabalho. Sendo assim, no campo educacional, não é diferente, isso se comprova retomando importantes estudos desenvolvidos neste meio, com ideologias que permanecem no ideário ainda hoje.

Amigues (2003) lembra-nos que nos anos de 1930 a 1950, na França e nos Estados Unidos predominava a abordagem positivista, preocupada com a contratação ou formação dos ditos "bons" professores. Por volta de 1970, temos como paradigma o chamado "processo-produto", que teve como objetivo relacionar o desempenho dos alunos (produto) com as dimensões do ensino (processo), assim, a aprendizagem eficaz dependia diretamente das ações do professor, que eram consideradas como boas ou ruins, associando-se aos conceitos do behaviorismo de estímulo-resultado.

Ainda se inscrevendo no paradigma "processo-produto", a abordagem cognitivista vai substituir o behaviorismo. Inserido nessa abordagem, o professor é visto como um ator racional, que desenvolve estratégias a partir de julgamentos de sua própria ação ou dos alunos. Amigues (2003) ressalta que os trabalhos apoiados nessas ideias colocam em relação direta as práticas pedagógicas do professor com os resultados dos alunos, contribuindo com a ideia do professor ideal e eficaz, pois se considera que as ações do professor em situação real, em sala de aula, são produtos de suas escolhas, exclusivamente, conscientes, desconsiderando, entre outros aspectos, o papel da 
instituição de ensino e do contexto sócio-histórico, visto que não fazem parte das escolhas racionais do professor.

Por outro lado, as pesquisas em didática de disciplinas não se atentaram aos gestos profissionais dos professores (AMIGUES, 2003). Da mesma forma, teorias cognitivistas, construtivistas e a reorientação delas em perspectivas sócio-construtivistas deixaram em segundo plano o trabalho real do professor. A essas teorias, ainda podemos acrescentar que pesquisas mais recentes, engajadas no estudo da tecnologia, que se limitam a estudar os tipos de interações e os impactos das $\mathrm{TICE}^{16}$ no ensino, deixando também em segundo plano o trabalho do professor, como ressalta Amigues (2003).

Em síntese, na perspectiva da ergonomia da atividade, esses estudos não levam em conta o agir dos professores e os elementos das situações reais de ensino (AMIGUES, 2003; FAÏTA e SAUJAT, 2010), como atividades de preparação de aulas, reelaboração e execução de tarefas prescritas pela instituição/escola, participação em reuniões pedagógicas, reuniões de pais e mestres etc. Dessa forma, conforme Amigues (2002, 2003, 2004) e Saujat (2001, 2002, 2004), o professor não se relaciona somente com alunos e dentro da sala de aula, mas atua dentro de um ambiente complexo de ensino, e interage com pais, funcionários do local de ensino, outros profissionais, colegas etc.

Na mesma perspectiva, Bronckart (2008) explica que foi a evolução das didáticas escolares, juntamente com os trabalhos ligados às correntes centradas na atividade de trabalho, que levou à emergência desse novo campo de trabalho: o trabalho do professor. Apoiado na ergonomia de língua francesa, esse campo de trabalho coloca o professor no centro do estudo, buscando compreender seu trabalho em sua totalidade.

Segundo Souza-e-Silva (2002), o taylorismo possibilitou observar uma divisão do trabalho entre aquele que entende o trabalho, o "expert", e por isso vai preparar e organizar o trabalho, e aquele que executa o que foi estabelecido pelo "expert". A ergonomia francesa parte dessa diferença e nomeia essa divisão como trabalho prescrito e trabalho real ${ }^{17}$, respectivamente. Assim, há o trabalho que é prescrito pelas hierarquias, ou seja, o que deve ser feito pelo trabalhador, e o trabalho efetivamente realizado pelo trabalhador. Souza-e-Silva (2002) explica que esses níveis nos permitem perceber a variabilidade do trabalho humano. No entanto, ao compreendermos esses dois conceitos

\footnotetext{
16 Tecnologias de Informação e Comunicação aplicadas à Educação.

${ }^{17}$ Ao invés de trabalho real, utilizamos o termo trabalho realizado, pois nos baseamo em Clot (1999). Essa diferença ficará mais clara mais a frente.
} 
propostos pela ergonomia, percebemos que as análises do trabalho limitavam-se às prescrições definidas hierarquicamente ou à observação do trabalho realizado, desconsiderando as trocas verbais como objeto de estudo e análise.

Diante disso, a abordagem ergonômica começou a refletir sobre conceitos e procedimentos de análises que pudessem fazer com que o 'trabalho' fosse encarado por outra perspectiva, considerando outros problemas, como os ligados às questões de saúde, stress, condições de trabalho etc. $\mathrm{Na}$ esteira desses estudos, surgiram a clínica da atividade, preocupada com as questões de trabalho em geral, e a ergonomia da atividade dos profissionais da educação (ERGAPE ${ }^{18}$ ) (AMIGUES, FAÏTA e KHERROUBI, 2003), interessada nas questões ligadas diretamente ao trabalho educacional. Dentro dessa perspectiva, a ação do professor é considerada a partir do que é prescrito pela instituição, analisando a distância entre o trabalho efetivamente realizado pelo professor e o que a instituição vê como objetivo de aprendizagem. É para a discussão específica desses conceitos que se volta a próxima seção.

\subsection{O trabalho prescrito, o realizado e o real da atividade}

Um dos objetivos desta pesquisa é estudar o papel das prescrições no trabalho do professor iniciante de FLE, para tanto pretendemos analisar o trabalho prescrito deste professor, confrontando-o ao trabalho realizado e ao real de sua atividade. Assim, uma das questões que nos colocamos nesta pesquisa e que buscamos responder é: Quais são as prescrições no trabalho do professor iniciante de língua estrangeira de um curso extracurricular em uma Universidade de São Paulo? Qual o seu papel? São explícitas ou implícitas?

Para respondê-las, buscamos constituir um quadro teórico que nos permita compreender o que é o trabalho prescrito e como as prescrições se materializam e se realizam, em geral, mas sobretudo, no trabalho educacional. Vejamos, portanto, alguns dos conceitos sobre trabalho prescrito que nos permitirão posteriormente interpretar nossos dados.

Amigues (2004) esclarece que o trabalho prescrito é constituído pela tarefa do trabalhador, para este autor, a tarefa deve ser entendida como "( a)o que deve ser feito $\mathrm{e}$

\footnotetext{
${ }^{18}$ Ergonomie de l'Activité des Professionnels de l'Éducation
} 
pode ser objetivamente descrita em termos de condições e objetivos, de meios (materiais, técnicos...) utilizados pelo sujeito" (AMIGUES, 2004, p.39, destaques do autor). O estudo da tarefa, e por consequência, do trabalho prescrito, é fundamental para a compreensão do trabalho em seu sentido mais amplo, visto que, de acordo com Clot e Yvon (2004), baseados em Vygotski (1978), o diálogo entre o sujeito e a tarefa constitui a atividade. Se a tarefa é o que deve ser feito pelo trabalhador, a atividade, segundo Amigues (2004, p.3940, destaques do autor):

corresponde ao que o sujeito faz mentalmente para realizar essa tarefa, não sendo portanto diretamente observável mas inferida a partir da ação concretamente realizada pelo sujeito. Logo, ela remete, classicamente, aos processos cognitivos, aos cálculos mentais ou estratégias a que o sujeito recorre para organizar os meios que lhe permitirão alcançar o objetivo da ação.

Conhecendo os conceitos de tarefa e atividade e a relação sujeito-tarefa-atividade, podemos pensar nos sujeitos envolvidos na produção e execução da tarefa do trabalhador. Conforme Amigues (2004), a tarefa não é determinada pelo próprio sujeito que a desempenha, mas pela hierarquia. A respeito disso, Berthet e Cru (2003, p.86), dialogando com os estudos de Daniellou (2000), redefinem sua acepção de prescrição, afirmando que "uma prescrição é uma injunção emitida por uma autoridade situada em posição hierárquica. No entanto, as autoridades podem ser múltiplas e a prescrição indicará o conjunto de injunções emitidas pelas autoridades"19.

Temos, portanto, duas concepções de prescrição: primeiramente, no contexto de trabalho não há apenas uma prescrição, mas várias (BAZET, 2002), sendo assim, a prescrição é um conjunto de obrigações, ordens, regras etc. Em segundo lugar, podemos dizer que esse conjunto de prescrições não é formado somente dentro de uma instituição e por uma única autoridade, pelo contrário, pode vir de diferentes esferas. Para exemplificar, Berthet e Cru (2003) propõem pensarmos em um mestre de obras que pode receber instruções do arquiteto, de textos legislativos e normativos, que não estão ligados diretamente à empresa, e da própria instituição, como, por exemplo, da direção da empresa.

\footnotetext{
${ }^{19}$ Tradução nossa do original: une prescription est une injonction de faire émise par une autorité placée en position hiérarchique. Toutefois, les autorités peuvent être multiples et la prescription désignera alors l'ensemble des injonctions émises par des autorités".
} 
Nesse sentido, refletindo sobre o trabalho do professor, seu trabalho prescrito é um conjunto de tudo o que é estabelecido pela instituição escolar e também o que é comunicado aos professores, com o intuito de auxiliá-los a realizar seu trabalho, assim como o define Goigoux (2002). Além disso, as prescrições para o trabalho do professor podem vir de autoridades ligadas diretamente à instituição de ensino, como diretor, coordenador etc., ou ainda de hierarquias superiores à instituição, como os Parâmetros Curriculares Nacionais (PCNs), proposto pelo Governo Federal, no caso do ensino no Brasil, e o Quadro Europeu Comum de Referência (QECR), para o ensino de línguas estrangeiras, proposto pelo Conselho da Europa. A respeito disso, Amigues (2003) explica que o fator que contribui para aumentar a imprecisão da prescrição, caracterizando-as como "prescrições vagas", é a pluralidade de canais de sua difusão. Além das que já citamos, as prescrições para o trabalho do professor podem vir de livros pedagógicos ${ }^{20}$, documentos prescritivos, reuniões pedagógicas etc. A partir disso, para que seu trabalho seja possível, o professor precisa organizar essas prescrições vagas (AMIGUES, 2004), redefinindo-as para que o trabalho possa ser realizado.

Bazet (2002) acrescenta que as prescrições têm duas vertentes, por um lado atendem às demandas da instituição, de outro lado, ajudam o trabalhador a tomar decisões para realizar o que se espera dele. Sobre este segundo aspecto, Daguzon e Goigoux (2007) explicam que o trabalhador pode redefinir essas tarefas; o termo "tarefa redefinida" é, segundo os autores, empregado por Leplat $(1980,1997)$ e quer dizer que é a tarefa que o trabalhador dá a ele mesmo em resposta as suas prescrições, ou seja, o trabalhador redefine sua tarefa para compreender seu trabalho (Daguzon e Goigoux, 2007, p.2).

Amigues $(2009$, p.22) também aborda esse mesmo conceito de tarefa redefinida, mas utilizando o termo "reconcepção":

\footnotetext{
a prescrição suscita, através de um diálogo entre a prescrição e os recursos disponíveis, uma atividade de reconcepção, não apenas de objetivos e de meios de ação, mas também, do meio de trabalho que possibilitará colocá-los em prática [...] esta atividade de transformação da prescrição, para ser apropriada, não se dá sem conflitos ou tensão entre os sujeitos do "métier"21
}

\footnotetext{
${ }^{20}$ Em nossa pesquisa, optamos por fazer um recorte e analisar apenas um documento de prescrição.

${ }^{21}$ Tradução nossa do original: la prescription déclenche, à travers un dialogue entre la prescription et les ressources disponibles, une activité de re-conception, non seulement des buts et des moyens d'action, mais aussi du milieu de travail qui permettra de les mettre en œuvre ; milieu de travail des conseillers comme
} 
A prescrição da tarefa dada ao professor e sua realização não é direta, mas mediada pelo trabalho de "organização de prescrições vagas" (AMIGUES, 2004). Podemos encarar, então, a preparação de aula como uma redefinição da tarefa ou "reconcepção", que a transforma em autoprescrição, já que o professor faz uma prescrição para si mesmo, a partir das prescrições gerais em seu contexto de trabalho. Uma das questões que esta pesquisa busca responder é: Como o professor iniciante concebe seu trabalho? E, por isso, compreender as prescrições e a maneira como o professor as reconcebe é importante.

Sabendo que esta reconcepção do trabalho ocorre devido à distância natural entre o trabalho prescrito e realizado, Lousada e Barricelli (2011) afirmam que é a partir da adaptação das prescrições que o professor pode construir sua "identidade profissional".

O trabalho de reorganização das tarefas e do meio de trabalho é realizado também pelos coletivos de trabalho. Assim, o coletivo de trabalho não é apenas uma resposta a uma injunção hierárquica de "trabalhar em equipe" (SOUZA-E-SILVA, 2002), mas principalmente uma mobilização coletiva para dar uma resposta comum às prescrições. De acordo com Clot et al. (2000), a reorganização coletiva possui prescrições importantes para a realização do trabalho.

Outro fator importante sobre o conceito de prescrição é tratado por Barricelli (2012), que, apoiada em alguns estudiosos do trabalho, como por exemplo, Amigues (2004), explica que as prescrições podem ser explícitas ou implícitas. As prescrições explícitas são as tarefas claramente estabelecidas pela instituição ou pelos manuais, ou seja, são as normas efetivamente declaradas. Já as prescrições implícitas ficam no plano do subentendido, como por exemplo, o modo de se vestir, a postura esperada do profissional etc.

O segundo conceito que adotamos é o de trabalho realizado. Se o trabalho prescrito pode ser considerado como a tarefa dada por uma hierarquia, o trabalho realizado pode ser entendido como "a atividade que é efetivamente realizada" (LOUSADA, 2004). Como nos explica Lousada (2006), além do trabalho que constitui a tarefa prescrita, há o trabalho que é resultado da adaptação dessa tarefa prescrita e que a transforma em trabalho realizado. Em outras palavras, segundo a mesma autora, o trabalhador recebe uma tarefa, a partir dessa tarefa ele desenvolve uma atividade de

celui des enseignants. Et cette activité de transformation de la prescription pour être appropriée ne va pas sans conflits ou tensions parmi les gens de métier. 
trabalho com o objetivo de realizá-la: ao resultado dessa atividade de trabalho chamamos de trabalho realizado. Com esse conceito, podemos pensar que a tarefa é o que é pedido para o trabalhador realizar; ele, por sua vez, vai desenvolver sua atividade de trabalho, buscando adaptar o que é preciso fazer pelo o que é possível fazer, ou seja, adaptar a tarefa à situação real de trabalho.

A partir dos conceitos de trabalho prescrito e trabalho realizado, Clot (1999) propõe outro: o de real da atividade. Vimos que para a Ergonomia o termo "trabalho real" corresponde ao trabalho efetivamente realizado. No entanto, Clot (1999) propõe o termo "real da atividade" que compreende, além do trabalho realizado, também as atividades não realizadas, que por algum motivo não foi possível cumpri-las.

Para Clot, o real da atividade é o trabalho realizado somado a tudo aquilo que se pretendia fazer, mas que por algum motivo não foi possível, ou seja, ele é composto por tudo o que se pode ver somado a tudo aquilo que não se vê (CLOT, 1999, 2001). Desse modo, Clot (2001, p.127) traz à noção do real os conceitos de refazer e desfazer, afirmando que o real da atividade engloba o que o trabalhador faz, o que queria ou podia fazer, o que pensa fazer depois, o que não faz ou não faz mais, o que procura fazer para superar os obstáculos, o que faz para não fazer o que é para se fazer. Para chegar a esse conceito, Clot (2014, p.129) baseia-se nos estudos de Vygotski (1925/2003) para afirmar:

\footnotetext{
Aquilo que não é realizado, quer ele queira ou não, faz parte da atividade. Não só as atividades impedidas mas também as atividades realizáveis, não só o impossível, mas também o possível. "O homem a cada minuto está cheio de possibilidades não realizadas." (Vygotski, 1925/2003, p. 76). E essas possibilidades, por não terem sido realizadas, não são menos reais para Vygotski. Essa não-realização possui o status paradoxal de "realidade incontestável" (Vygotski, 1925/2003, p. 494).
}

Dialogando com os estudos de Guérin et al. (2001), Lousada (2006) aponta que, quando um trabalhador precisa ou quer explicar sua atividade de trabalho, normalmente, ele fala sobre sua tarefa, o que está prescrito (2006, p.74), sendo difícil identificar o real da atividade. Por exemplo, se um professor é indagado sobre seu trabalho, muito provavelmente, ele vai se centrar sobre a matéria ensinada, seus objetivos e até mesmo as tarefas burocráticas, ou seja, seu trabalho prescrito. Além disso, a observação do trabalho realizado não é suficiente para compreender o real da atividade, visto que, conforme Clot 
(2001, p.1), a atividade realizada é "a atualização de uma das atividades realizáveis". Percebemos, diante disso, a dificuldade para identificar o real da atividade. A partir dessa problemática, apresentaremos, mais a frente, alguns métodos desenvolvidos por estudiosos do trabalho, que procuram criar verbalizações que podem dar acesso ao real da atividade do trabalhador, em nosso caso, o professor. No entanto, antes de abordar a questão dos métodos de intervenção nas situações de trabalho, parece-nos importante apresentar o conceito de gênero profissional/gênero da atividade, tal como apresentado pelos pesquisadores da clínica da atividade e ergonomia da atividade (CLOT e FAÏTA, 2000; CLOT et al 2000; FAÏTA, 2004). Esse conceito nos auxilia a compreender melhor a atividade de trabalho da professora que é objeto de nosso estudo, pois permite identificar, nos dados analisados, características que não são exclusivas da atividade da professora em questão, mas estão relacionadas ao trabalho do professor em geral, sobretudo o professor de línguas estrangeiras.

Clot, Faïta, Fernandez e Scheller (2000) propõem a seguinte definição para gênero profissional:

\begin{abstract}
entre a organização do trabalho e o sujeito (existe) um trabalho de reorganização da tarefa pelos coletivos profissionais, uma recriação da organização do trabalho pelo trabalho de organização do coletivo. Nós designamos este trabalho como o gênero social do "métier", o gênero profissional $^{22}$
\end{abstract}

O gênero profissional é oriundo da noção de gêneros de discurso, proposto por Bakhtin (1953/1997) para pensar na atividade linguageira. Clot e Faïta (2000), respaldados em Bakhtin, explicam que os gêneros do discurso funcionam como um "estoque de enunciados esperados, modelos de maneiras de dizer ou de não dizer em um espaço-tempo sociodiscursivo 23 " (2000, p.10). Do mesmo modo, Faïta (2004) explica que no contexto de ensino também são produzidas "formas de fazer mais ou menos difundidas na profissão" (2004, p.64), caracterizadas como “obrigações” (CLOT e FAÏTA, 2000,

\footnotetext{
22 Tradução nossa do original: entre l'organisation du travail et le sujet lui-même, un travail de réorganisation de la tâche par les collectifs professionnels, une recréation de l'organisation du travail par le travail d'organisation du collectif. Nous désignons ce travail comme le genre social du métier, le genre professionnel.

${ }^{23}$ Tradução nossa do original: Il s'agit d'un stock d'énoncés attendus, prototypes des manières de dire ou de ne pas dire dans un espace-temps sociodiscursif.
} 
p.9) que os trabalhadores compartilham para conseguir trabalhar, que independem das prescrições estipuladas pela instituição.

Conforme Clot e Faïta (2000), o gênero profissional contribui para que o trabalho seja possível, visto que não é necessário sempre criar todas as atividades a cada ação; entendemos, então, que o gênero profissional permite uma economia da ação do trabalhador. Os mesmos autores acrescentam que os gêneros da atividade são compostos por gêneros dos discursos e por gêneros de técnicas, sendo o último, definido como um conjunto de técnicas de um determinado meio profissional.

O gênero profissional não deve ser encarado com algo acabado e estável, pelo contrário, há o trabalho de ajustar o gênero para ser um instrumento da ação, este trabalho de ajustamento é designado como estilo da ação (CLOT e FAÏTA, 2000). Isso significa que o gênero profissional precisa ser adaptado às situações de trabalho e às propriedades individuais usadas para realizar a tarefa. Usando os termos de Clot et al. (2000, p.15), o estilo individual é "a transformação dos gêneros na história real das atividades no momento de agir, em função das circunstâncias", sendo assim, o estilo é a "metarmorfose do gênero em ação" (2000, p.15).

A partir desses conceitos, podemos abordar outro conceito desenvolvido por Clot $(2007,2013)$ a respeito das dimensões do trabalho. Clot (2007, p.86, destaques do autor) define o métier dizendo que ele:

\footnotetext{
[um métier] não é, certamente, apenas uma "prática". Também não é apenas uma atividade. Nem apenas uma profissão. Preferimos defini-lo como uma discordância criativa - ou destrutiva - entre as quatro instâncias em conflito de uma arquitetura fundamentalmente social. O métier, conforme nós o entendemos, é finalmente, irredutivelmente pessoal, interpessoal, transpessoal e impessoal ${ }^{24}$.
}

Assim, para Clot (2007), o métier é pessoal no sentido em que em cada situação ele é singular. As situações do métier estão sempre expostas ao inesperado (2007, p.86). A atividade não é isolada, ela tem sempre um destinatário, razão pela qual o métier é

\footnotetext{
${ }^{24}$ Tradução nossa do original: un métier n'est sûrement pas seulement une « pratique ». Ce n'est pas non plus seulement une activité. Et pas non plus, selon nous, une profession. On le définirait volontiers comme une discordance créatrice - ou destructrice - entre les quatre instances en conflit d'une architecture foncièrement sociale. Le métier au sens où nous l'entendons est finalement à la fois irréductiblement personnel, interpersonnel, transpersonnel et impersonnel.
} 
interpessoal. O métier também é atravessado por uma história coletiva, ou seja, que vai além dos sujeitos e ao longo da história, caracterizando sua dimensão transpessoal. Finalmente, o métier impessoal está sob o ângulo da tarefa, da função que é definida. Conforme Clot (2007), o métier vive graças às ligações possíveis e impossíveis e às rupturas entre as quatro instâncias apresentadas. Em outras palavras, é o movimento entres as atividades pessoais e interpessoais, a história coletiva transpessoal e as tarefas prescritas impessoais que permite que o métier exista.

Esses conceitos colaboram para compreendermos mais do que o trabalho realizado do professor, mas também: o que ele deixou de fazer, porque não o fez e que efeitos isso tem sobre si e sobre seu trabalho.

Para tanto, voltamo-nos para os métodos desenvolvidos pelos estudiosos do trabalho que tentam criar verbalizações que podem dar acesso ao real da atividade do professor.

\subsection{A Instrução ao Sósia como método de transformação}

Antes de apresentarmos os métodos desenvolvidos pela Clínica da Atividade e Ergonomia da Atividade, parece-nos importante salientar um obstáculo constatado por Clot e Yvon (2004, p.17):

\footnotetext{
é preciso antes de tudo tirar uma lição dos obstáculos que apresentam em toda análise da atividade: toda observação é uma transformação do objeto. O pesquisador, por sua presença, modifica as condições reais de observação colocando-se como destinatário potencial da atividade profissional. Desse obstáculo, a clínica procura fazer uma pesquisa ${ }^{25}$.
}

A respeito dessa afirmação, é importante dizer que a professora participante desta pesquisa produziu textos (orais e escritos), sobre seu trabalho, sabendo previamente que seriam analisados. Por essa razão, é preciso considerarmos que a presença do pesquisador pode alterar as condições reais do contexto analisado. Por outro lado, ao trazer a atividade

\footnotetext{
25 Tradução nossa do original : "il faut avant tout tirer leçon des obstacles qui présentent à toute analyse de l'activité : toute observation est une transformation de l'objet. Le chercheur, par sa présence, modifie les conditions réelles d'observation en s'ajoutant comme destinataire potenciel de l'activité du professionnel. De cet obstacle, la clinique cherche à faire une ressource".
} 
para o plano da observação, para o plano consciente, ela já se torna outra para o próprio sujeito, mesmo que não haja pesquisador envolvido ou pesquisa sendo realizada.

Os estudos dos métodos de intervenção aparecem nos trabalhos de Vygotski (1927/1999), assim como indica Friedrich (2010). A autora explica que o método dominante na psicologia, na época de Vygotski, era o método direto. No entanto, Vygotski (1927/1999) contesta o uso exclusivo de métodos diretos na psicologia, já que com eles "só é possível estudar o que nos é dado pela experiência imediata"26 (FRIEDRICH, 2010, p.41). Assim, de acordo com Friedrich (2010), Vygotski questiona como é possível analisar diretamente o nascimento dos fenômenos psíquicos na evolução da espécie humana.

Sabendo que os métodos diretos não conseguem dar conta de todos os ramos da psicologia (FRIEDRICH, 2010), Vygotski opta pelo uso de método indireto, para exemplificar sua utilização, Vygotski, compara-o com o uso um termômetro: o termômetro é fundamental para o estudo do calor, pois não é possível observar o calor e suas variações diretamente, mas apenas por meio da indicação do mercúrio e do álcool (FRIEDRICH, 2010), ou seja, com o termômetro. Sendo assim, para Vygotski, era necessário refletir sobre um "termômetro" da psicologia (FRIEDRICH, 2010).

A respeito disso, ao considerarmos que a atividade vivenciada não pode ser "tocada" com o dedo (HUBAULT, 1996 apud AMIGUES; FÉLIX; ESPINASSY, 2014), ou seja, não é diretamente acessível, entendemos que não é possível compreendê-la através de métodos diretos, como por exemplo, apenas por meio da observação do trabalho realizado. A partir dessa problemática, os pesquisadores da clínica da atividade e da ergonomia da atividade desenvolveram métodos indiretos, com base vigotskiana, para tentar acessar o real da atividade, esses métodos são: a autoconfrontação e a instrução ao sósia.

Esses métodos não pretendem apenas registrar a atividade efetivamente realizada, mas revelam-se instrumentos que podem permitir, ao sujeito, por meio de verbalizações, a tomada de consciência da própria atividade e da situação de trabalho. Essa tomada de consciência é, segundo Clot (2001), fundamental para que seja possível a transformação da situação de trabalho.

\footnotetext{
${ }^{26}$ Tradução nossa do original: "qu'il n'est possible d'étudier que ce qui nous est donné dans l'expérience immédiate".
} 
Os métodos indiretos possibilitam que aquilo que não se pode ver (a atividade do sujeito, o que o leva a reconceber as prescrições) seja explicado por aquilo que se pode ver (a ação ${ }^{27}$ ) (AMIGUES; FÉLIX; ESPINASSY, 2014). Desse modo, o real da atividade e o trabalho realizado podem ser analisados pela observação das condutas verbais e nãoverbais realizadas pelo trabalhador e materializadas pelos textos que eles produzem (LOUSADA, 2006). O que há em comum entre esses procedimentos, como explica Lousada (2006) é a possibilidade da troca de papeis, ou seja, a pessoa que é observada pelo pesquisador ${ }^{28}$ ou pelo seu grupo de trabalho, passa a observar sua própria ação pelos olhos do outro, contribuindo, assim, com o seu desenvolvimento profissional.

Clot, Faïta, Fernandez e Scheller (2000) esclarecem que, dentro da perspectiva da clínica da atividade, procura-se compreender a dinâmica da ação dos sujeitos. Para tanto, é desenvolvida uma coanálise com os coletivos de trabalhadores. Essa coanálise se concentra no desenvolvimento dos sujeitos e dos coletivos de trabalhadores. Conforme esses autores, a importância dos coletivos está no fato de que somente eles podem produzir mudanças sustentáveis no local de trabalho.

Foi D. Faïta $(2002,2004)$ quem propôs o método da autoconfrontação, em seguida desenvolvido com seu colega Y. Clot (CLOT \& FAÏTA, 2000, 2001) e outros pesquisadores (FAÏTA e VIEIRA, 2003). Para criá-la, Faïta (2002, 2004) baseia-se no conceito de método indireto, proposto por Vygotski, (1934/1997, 2009) como meio de investigação empregado para ter acesso aos conteúdos não acessíveis (CLOT, 2001).

É importante ressaltar que, assim como aponta Lousada (2006), na França, a demanda de intervenção ergonômica provém das instituições, que convidam uma equipe de ergonomistas para transformar o contexto de trabalho. Diferentemente dos trabalhos de pesquisas de ergonomia desenvolvidos na França, em nossa pesquisa a demanda de intervenção partiu de uma demanda informal do coletivo de trabalho constituído em um grupo de pesquisa ${ }^{29}$.

\footnotetext{
${ }^{27}$ Aqui, gostaríamos de chamar a atenção para o fato de que os conceitos de atividade e ação não são exatamente os mesmos para a Clínica da Atividade e para a Ergonomia da Atividade e, por outro lado, para Bronckart (2006), que também faz parte de nosso quadro teórico.

${ }^{28}$ Nesta pesquisa, adotamos o termo "pesquisador" referindo-nos ao "intervenant", ou seja, o profissional que faz a intervenção. Essa opção foi feita para facilitar a compreensão e a leitura; no entanto, ressaltamos a necessidade de refletirmos sobre a tradução desse termo para o português.

${ }^{29}$ Explicaremos mais detalhadamente no capítulo de metodologia.
} 
O método de autoconfrontação se desenvolve em três etapas, conforme Clot, Faïta, Fernandez e Scheller (2000). A primeira etapa da autoconfrontação é a constituição do grupo de análise, trata-se de um extenso trabalho de observação do ambiente de trabalho e do meio profissional. Clot et al. (2000) explicam que, nessa etapa, os próprios trabalhadores determinam o grupo que parece mais representativo para participar de um trabalho de coanálise, no entanto os pesquisadores podem emitir suas opiniões sobre essas escolhas. Em seguida, o grupo elege as sequências de atividades que serão filmadas. Cada um dos membros do coletivo será filmado em situação de atividade mais próxima possível uns dos outros, com intuito de promover futuras comparações sobre maneiras de se fazer.

Conforme Clot e al. (2000), a segunda etapa é das autoconfrontações, momento em que são realizadas as filmagens. Primeiramente são filmadas as sequências de atividades de cada um dos integrantes do grupo. Após isso, há a entrevista de autoconfrontação simples, que consiste em uma filmagem dos comentários que o trabalhador, confrontado ao registro sua própria atividade, faz ao pesquisador. Clot et al. (2000) esclarecem que, na autoconfrontação simples, o sujeito, ao assistir à filmagem, pode dizer o que ele fez, o que poderia ter feito, o que não pôde fazer etc. A entrevista é conduzida pelo pesquisador, que inclusive manipula o controle remoto, buscando criar e direcionar diálogos a partir das atividades realizadas e assistidas e dos comentários do trabalhador a respeito delas. Como já vimos, estes métodos buscam criar verbalizações que podem dar acesso ao real da atividade (CLOT et al., 2000).

Em outro momento, é realizada a entrevista de autoconfrontação cruzada. Formada por dois membros do coletivo e pelo pesquisador, é uma entrevista também filmada que consiste em apresentar sucessivamente a esses dois trabalhadores as filmagens de suas atividades. Enquanto assistem à atividade de um trabalhador, o pesquisador e o seu colega, ambos com controles remotos, tecem comentários sobre a atividade do outro. Os papéis são invertidos de forma que os dois trabalhadores sejam confrontados com os comentários do colega. Nesse diálogo, podem aparecer controversas profissionais, revelando o estilo de ação de cada um deles (CLOT et al, 2000).

A terceira etapa é a de extensão do trabalho de análise ao coletivo profissional. Esta última fase é a apresentação da montagem das sequências de autoconfrontações para o coletivo de trabalho. Usando os termos de Clot et al. (2000, p.5): “um ciclo se estabelece entre o que os trabalhadores fazem, o que dizem, e, por fim, o que eles fazem do que 
dizem" ${ }^{30}$. Ainda de acordo com Clot et al. (2000) estas etapas caracterizam uma metodologia de análise do trabalho, que procura fazer com que o coletivo reflita sobre seu próprio trabalho e privilegia o aumento do poder do coletivo de transformar objetivos, meios e conhecimentos de sua atividade profissional.

Utilizamos nesta pesquisa um outro método indireto, que tem origem diversa da autoconfrontação; trata-se do método de instrução ao sósia (doravante IS), proposto pelo psicólogo Ivar Oddone na década de 70, nos seminários de formação operária da Universidade de Turim, que foi retomado dentro da perspectiva da clínica da atividade (CLOT, 1999, 2001) e da ergonomia da atividade do trabalho do professor (AMIGUES, 2004, SAUJAT, 2004, 2005), linhas adotadas para nossa pesquisa.

Assim, como o método de autoconfrontação, a IS também possibilita que os interlocutores (trabalhador e pesquisador) desenvolvam um diálogo sobre a experiência do trabalhador, permitindo a transformação da situação de trabalho. Utilizamos a IS por ser o método mais adequado no que diz respeito ao contexto em que nossa pesquisa foi desenvolvida $^{31}$, como já salientamos. Em outras palavras, no caso da França, a intervenção no contexto de trabalho parte de uma demanda da instituição de trabalho, mas também pode partir dos próprios trabalhadores, assim como em algumas pesquisas já desenvolvidas no Brasil pelos grupos ALTER-CNPq e ALTER-AGE-CNPq. Após essa demanda, constitui-se um grupo de pares com trabalhadores que desenvolvam a mesma atividade e que se apresentam como voluntários para participar dos procedimentos de intervenção. Assim, são combinados, dentro desse pequeno coletivo, alguns encontros, sendo que a quantidade vai depender do contexto onde se desenvolve a pesquisa.

Conforme Clot (2001), a IS foi apresentada por Oddone (1981) aos funcionários da Fiat, como um meio que permitia ajudar os coletivos de trabalho, ampliando a ação dos trabalhadores sobre o meio de trabalho e também sobre si mesmos. Desse modo, a IS consistia em uma entrevista, que implicava um trabalho de grupo, em que o sujeito voluntário recebia a seguinte instrução: "Suponha que eu sou seu sósia e que amanhã eu me encontro na condição de substituí-lo em seu trabalho. Quais são as instruções que

\footnotetext{
${ }^{30}$ Tradução nossa do original : Un cycle s'établit entre ce que les travailleurs font et ce qu'ils en disent, et, pour terminer, ce qu'ils font de ce qu'ils disent.

${ }^{31} \mathrm{O}$ contexto da nossa pesquisa será melhor desenvolvido mais à frente, no capítulo de metodologia.
} 
você deverá me transmitir a fïm de que ninguém perceba a substituição?" 32 (ODDONE \& al., 1981 apud SAUJAT, 2005, p.1). Oddone tinha como preocupação focalizar os detalhes do trabalho, preocupando-se mais em "como" é feita a atividade do que "por que" é feita. A IS foi proposta como um trabalho de coanálise, visto que o profissionalinstrutor era coanalista de sua própria atividade (CLOT, 2001).

Retomada pelos pesquisadores da equipe ERGAPE (ergonomia da atividade dos profissionais da educação), a IS teve o registro anterior modificado, assim o professor/instrutor voluntário recebe a seguinte tarefa do pesquisador/sósia: "Eu tenho que lhe substituir amanhã em sua aula, então eu vou tentar usar da sua experiência para recolher o máximo de conselhos, de truques... de modo a obter o melhor possível deste caso!" 33 (SAUJAT, 2005, p.1).

Diante dessa proposta, o professor, no papel de instrutor, precisa instruir seu sósia (o pesquisador) sobre o que é preciso ser feito, exatamente, em seu contexto de trabalho, para que ninguém perceba a mudança. Nota-se que não se trata de um substituto, mas de um sósia, sendo assim, as instruções precisam ser detalhadas: o que deve ser feito, o que não deve ser feito, o que deveria ser feito, mas não se faz etc. (CLOT, 2007). Dessa forma, o professor deve dirigir-se ao seu sósia, utilizando a segunda ou terceira pessoa do singular: $t u / v o c e ̂$ ( $t u$ em francês) e não o pronome $e u$ (je, em francês), usado somente pelo sósia. Dessa maneira, o professor/instrutor pode, por exemplo, começar sua instrução: Você vai chegar à escola às $9 \mathrm{~h}$ horas. O sósia, por sua vez, pode ajudar o instrutor a lembrar-se dessa regra, retomando-se com o pronome "eu" para reforçar o deslocamento do sujeito, por exemplo: o que eu devo fazer?; como eu posso fazer?; o que eu faço depois? etc.

O método de IS, de acordo com CLOT (2001), busca fazer com que o trabalhador, em situação hipotética de substituição, reflita sobre sua atividade de trabalho, imaginando-a no futuro próximo. Para tanto, o sósia, que não vê a situação de trabalho como seu instrutor, precisa descobrir a atividade, assim vai direcionando a entrevista, sobretudo para que o instrutor faça comentários a respeito de elementos que pareçam implícitos, buscando fazer o trabalhador mostrar aquilo que não estava previsto mostrar.

\footnotetext{
32 Tradução nossa do original: "Suppose que je sois ton sosie et que demain je me trouve en situation de te remplacer dans ton travail. Quelles sont les instructions que tu devrais me transmettre afin que personne ne s'avise de la substitution?"

33 Tradução nossa do original: Je suis amené à te remplacer demain dans ta classe, donc je vais essayer de me servir de ton expérience pour recueillir le maximum de conseils, de ficelles... de manière à me tirer le mieux possible de cette affaire!"
} 
Nesse sentido, o sósia deve levar em conta as quatro dimensões da experiência profissional, propostas originalmente por Oddone (CLOT, 2001; SAUJAT, 2005), as relações do trabalhador com: i) sua tarefa; ii) seus pares dentro do(s) coletivo(s); iii) a hierarquia; iv) as organizações formais e informais do mundo do trabalho. Dessa forma, a instrução fará com que esse trabalhador dialogue consigo mesmo e veja suas experiências profissionais "com olhos de seu sósia".

Logo após a entrevista, o pesquisador (já não mais na posição de sósia) pergunta ao trabalhador o que a IS lhe provocou, buscando uma reflexão sobre os efeitos que a experiência pode ter lhe causado. Esse questionamento serve como uma estratégia clínica, de modo que o trabalhador "se refaça”, pois é comum que ele fique afetado pelo exercício. Em seguida, o pesquisador abre a discussão aos membros do pequeno coletivo, que até então apenas observavam a entrevista. Essa discussão tem como objetivo fazer o trabalhador retomar as instruções, mas agora apoiando-se nos questionamentos de seus colegas, diante das dúvidas que tiveram durante a entrevista. É preciso reforçar que, assim como as questões do sósia não eram pautadas no "por que", mas no "como", nesse momento, os membros do grupo também devem preocupar-se em compreender as atividades do trabalhador-instrutor sem questioná-las ou sugerir outros modos de fazer (BATISTA e RABELO, 2013).

Essa primeira etapa é registrada em áudio e cabe aos trabalhadores, que foram os instrutores, transcrever suas instruções e produzir um comentário, com algumas reflexões surgidas nesse processo, que será apresentado no próximo encontro para o coletivo. Nesse momento, o trabalhador confronta-se com sua própria atividade, refletindo sobre as escolhas que venceram e as que foram abandonadas (Vygotski 1934/1997). Com isso, Clot (2001) explica que o método de IS se desenvolve em dois tempos. No primeiro momento, o sujeito é confrontado consigo mesmo pela mediação da atividade controlada pelo sósia e no segundo, o sujeito mensura as trocas materializadas por meio da escrita.

A segunda etapa, chamada de retorno à instrução ao sósia, consiste em uma discussão destinada a uma reflexão coletiva do grupo sobre as diferentes maneiras de fazer o trabalho. Essa etapa, também gravada em áudio, inicia-se com a leitura dos comentários escritos pelos trabalhadores-instrutores, produzidos a partir da transcrição da IS. Em seguida, o coletivo busca analisar as atividades de trabalho, não mais somente usando o "como fazer", mas também o "por que fazer"; nessa etapa, os membros confrontam e trocam experiências profissionais. 
Com isso, vemos que as etapas do método de IS podem ser organizadas com as fases de trabalho oral com o sósia, oral com o coletivo (grupo), escrito individual, oral coletivo (SAUJAT, 2005). Nesse sentido, o trabalho oral com o sósia funciona como uma troca de papeis, permitindo que o instrutor/professor veja suas experiências com os olhos de seu sósia e reflita sobre seu agir. O trabalho oral com o grupo consiste em produzir trocas diante do que foi realizado. Já o trabalho escrito individual, de transcrever a IS e tecer comentários, permite que a reflexão se materialize mediada pela escrita.

Diante da configuração desse procedimento de intervenção, apoiamo-nos em Saujat (2004b) e Faïta (2004), para defender o uso do método de instruções ao sósia com professores iniciantes. Para os autores, a análise das atividades do docente em início de carreira colabora para compreender o trabalho educacional, visto que a análise de sua atividade revela a falta de "modos de fazer" mais ou menos estáveis, reconhecidos e difundidos na profissão como verdadeiros gêneros profissionais.

Além disso, Saujat (2004, p.97) explica que a investigação com iniciantes também "abre uma porta sobre a origem de recursos intermediários elaborados por esses professores para superar as dificuldades inerentes à falta provisória de domínio dos

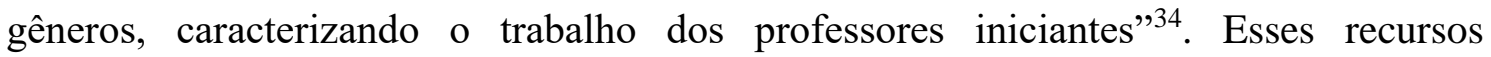
intermediários aprecem devido à dificuldade que o professor iniciante tem em dedicar-se à atividade didática dos alunos. Assim, há uma extrema preocupação desses professores em organizar e implementar regras de gestão da sala de aula (FÉLIX e SAUJAT, 2007).

Pelo que acabamos de explanar sobre as entrevistas de Instrução ao Sósia, vemos que, durante esse método, são produzidas verbalizações, ou seja, textos sobre o trabalho do professor. Esse fato chama a atenção para a questão da linguagem produzida pelo professor quando se emprega o método da IS e que não pode ser negligenciada. De fato, como temos apontado, muitos estudiosos se dedicaram a estudar o trabalho, do ponto de vista de sua organização e administração, e isso ocorre em diferentes áreas: psicologia, psicopatologia, ergonomia, ecologia, ciências cognitivas, matemática etc. No entanto, Souza-e-Silva (2002) afirma que, entre essas áreas, a linguagem não é objeto e nem foco de estudo científico. O que é mais intrigante é ver que as ciências da linguagem também

\footnotetext{
34 Tradução nossa do original: elle ouvre une trappe sur la genèse de ressources intermédiaires élaborées par ces derniers pour surmonter les difficultés inhérentes à la non-maîtrise provisoire des genres caractérisant le travail des enseignants expérimentés.
} 
não têm se dedicado tanto para o estudo da linguagem, menos ainda ligada às questões do trabalho (SOUZA-E-SILVA, 2002, p.62).

Alguns dos motivos pelos quais as ciências da linguagem não têm colaborado com estudos sobre linguagem e trabalho são explicados por Souza-e-Silva (2002). Primeiramente, ela esclarece que normalmente há a crença de que a linguagem é transparente, nesse sentido, há a ideia equivocada de que o interlocutor compreende exatamente o que o enunciador quer dizer. O segundo motivo diz respeito ao fato de a linguística ter se dedicado ao "estudo imanente da língua", ou seja, a língua estudada em si mesma e por si mesma, desconsiderando tudo o que for extralinguístico. Em terceiro lugar, a autora aponta que as atividades dos linguistas estiveram, durante muito tempo, vinculadas apenas às instituições de ensino (SOUZA-E-SILVA, 2002, p.62), procurando centrar-se na aprendizagem dos alunos e não abordando a questão do trabalho do professor.

Em nosso estudo, corroboramos a visão de Souza-e-Silva e procuramos, do ponto de vista dos Estudos Linguísticos, concentrarmo-nos na análise dos textos produzidos pelos professores em sua situação de trabalho, procurando contribuir com nossa especialidade para as pesquisas sobre o trabalho educacional. Para tanto, adotamos um quadro teórico-metodológico que traz as questões de linguagem como fundamentais para a compreensão do agir humano: a teoria do interacionismo sociodiscursivo, proposta por Bronckart (1999/2009, 2006 e 2008) e que apresentamos a seguir.

\section{O interacionismo sociodiscursivo}

Nesta seção, apresentamos uma das correntes teóricas que embasa nossa pesquisa: o interacionismo sociodiscursivo (doravante ISD), proposto por Bronckart (1999/2009, 2005, 2006, 2008), abordagem esta que se inscreve no movimento do interacionismo social (VYGOTSKI 1934/1997, 1999), do qual é uma variante e, ao mesmo tempo, um prolongamento (BRONCKART, 2006).

De acordo com Bronckart (1999/2009), o interacionismo social indica "uma posição epistemológica geral", na qual são reconhecidas várias correntes da filosofia e das ciências humanas, desenvolvidas por pensadores centrais como Bühler (1927), Dewey (1925), Mead (1934), Politzer (1928) e, sobretudo, Vygotski (1927/1999), e 
outros mais periféricos como Durkheim (1898), Saussure (1916), Wallon (1938) etc. (BRONCKART, 2005).

Apesar das diferentes perspectivas teóricas ou metodológicas, as correntes fundamentadas no interacionismo social têm um fator comum: todas aderem à tese de que "as propriedades específicas das condutas humanas são o resultado de um processo histórico de socialização, possibilitado especialmente pela emergência e pelo desenvolvimento dos instrumentos semióticos" (BRONCKART, 1999/2009, p.21, grifos do autor).

O ISD concorda com todos os princípios que fundaram o interacionismo social (BRONCKART, 2006, p.10), sobretudo com os três princípios gerais de sua versão original, retratados abaixo, tendo como base Bronckart (2006, p.9-10):

i) a questão da construção do pensamento consciente deve ser abordada paralelamente à questão da construção do mundo dos fatos sociais e das obras culturais, posto que os processos de individuação e os de socialização são "indissociáveis do mesmo desenvolvimento humano";

ii) as questões das Ciências Humanas devem apoiar-se no corpus da filosofia do espírito, desenvolvida de Aristóteles a Marx, além de considerar, simultaneamente, os problemas de intervenção prática, sobretudo a escolar;

iii) é preciso contestar a divisão dessas Ciências em várias disciplinas e subdisciplinas, pois os problemas de uma ciência do humano envolvem relações de interdependência, de um lado, entre aspectos cognitivos, culturais, linguísticos etc. e, do outro, os processos evolutivos e históricos.

O movimento do interacionismo social, de acordo com Bronckart (2005), preconizou uma organização de "reunificação" das ciências do humano, isso significa que a compreensão do funcionamento e do desenvolvimento do humano implica considerar a simultaneidade de suas dimensões biológica, social, cultural, cognitiva, linguageira, afetiva etc. Ou seja, a única forma de compreender os processos dinâmicos ou genealógicos que caracterizam a antropogênese, assim como a ontogênese, é por meio da análise dessas dimensões.

De acordo com esses princípios, o ISD não é considerado uma corrente linguística, psicológica ou sociológica, mas pretende ser visto como uma corrente da ciência do humano. Sendo que a particularidade do ISD é, usando os termos de Bronckart (2006, 
p.10), "de postular que o problema da linguagem é absolutamente central ou decisivo para essa ciência do humano".

O ISD se centra na abordagem da ontogênese humana desenvolvida pelo interacionismo social na obra "La signification historique de la crise en psychologie", de Vygotski (BRONCKART, 1999/2009, p.27). De acordo com Bronckart (2005), essa abordagem se baseia em um movimento descendente, visto que, diferentemente do construtivismo piagetiano, ela consiste primeiramente, examinar as interações sociais, a afetividade, a linguagem, entre outros, para em seguida, tratar das potencialidades cognitivas do sujeito. Esse movimento descendente examina, conforme Bronckart (2005, p.151): i) o conteúdo dos pré-construtos, oriundo da história social de um grupo; ii) as propriedades dos sistemas educativos e formativos formalizados ou não; iii) os mecanismos de apropriação e interiorização.

Nessa perspectiva de abordagem descendente da ontogênese, o ISD centraliza seus estudos nos pré-construtos (BRONCKART, 2005), mais precisamente "os préconstrutos que constituem os textos que abordam as atividades humanas e as modalidades escolares formais de realização de sistemas formadores, para abordar o desenvolvimento dos indivíduos sob seu ângulo epistêmico e praxeológico"35 (BRONCKART, 2005, p.152).

O projeto do ISD emergiu na Unidade de Didática das Línguas, na Faculdade de Psicologia e Ciências da Educação da Universidade de Genebra. Voltado para o ensino de línguas (BRONCKART, 2006), pois as pesquisas são desenvolvidas em escolas francófonas da Suíça, o ISD propõe um modelo teórico-metodológico que tem como objetivo analisar e refletir sobre o ensino de produção textual de gêneros e, mais recentemente, tem se voltado para o estudo de como o ensino de línguas acontece na sala de aula, abordando a formação de professores (SCHNEUWLY; DOLZ, 2010).

O ISD é conduzido, principalmente por dois grupos: o primeiro, LAF (Langage, Action e Formation), coordenado por Jean-Paul Bronckart, tem como áreas de pesquisa, conforme informações do site do grupo $^{36}$ : i) ações como formas de interpretação da atividade; ii) dinâmicas linguageiras, sistemas de atividade e desenvolvimento de pessoas; iii) das ciências humanas a uma ciência do humano: novas leituras de textos

\footnotetext{
35 Tradução nossa do original : "les pré-construits que constituent les textes commentant les activités humaines et sur les modalités scolaires ou formelles de réalisation des systèmes formateurs, pour aborder le développement des individus sous leur angle épistémique et praxéologique".

${ }^{36} \mathrm{https}$ ://www.unige.ch/fapse/recherche/groupes/ssed/formation-adultes/laf/ (consultado em 04/01/2016).
} 
fundadores; iv) reflexão como modo de produção de conhecimentos; v) mobilização de saberes profissionais nas interações no trabalho. O segundo grupo, GRAPHE (Groupe de Recherche des Langues et Formation des Enseignants: analyse du français enseigné), coordenado por Bernard Schneuwly e Joaquim Dolz, tem pesquisas, segundo informações do seu site ${ }^{37}$, voltadas ao estudo da didática das línguas e a formação de professores, sobretudo em relação ao ensino de francês, o grupo analisa os objetos ensinados nas práticas comuns em sala de aula, assim como, os objetos da formação de professores.

No Brasil, a pesquisadora Anna Rachel Machado contribuiu diretamente com as pesquisas sobre o ISD, um marco é a publicação do livro de Bronckart (1999), traduzido pela mesma pesquisadora, juntamente com Péricles Cunha. Além disso, Machado (2002, 2004) enriqueceu o debate sobre a importância dos textos para a análise do trabalho do professor e sobre o ensino e aprendizagem de língua materna ou estrangeira. Com isso, vários pesquisadores, sobretudo antigos alunos de A. R. Machado (ABREU-TARDELLI, 2006, BARRICELLI, 2012; BUENO, 2007; BUZZO, 2008; LOUSADA, 2006, entre outros), mas também outros estudiosos do ISD e membros do grupo ALTER-CNPq (GUIMARÃES, 2007; NASCIMENTO, 2011; PEREIRA, 2005, entre outros) contribuem atualmente com estudos sobre gêneros textuais, ensino-aprendizagem de língua materna e estrangeira e trabalho docente na perspectiva do ISD.

Bronckart (2005) explica que o programa de trabalho do ISD está articulado em três níveis. O primeiro nível é o de análise das atividades coletivas (atividades gerais e atividades linguageiras), das formações sociais (geradoras de regras, normas, valores etc.), dos textos (concretização das atividades linguageiras) e dos mundos formais (mundo objetivo, social e subjetivo).

O segundo nível busca analisar os processos de mediação e de formação desenvolvidos pelos grupos para garantir a transmissão e reprodução dos pré-construídos. Bronckart (2005) agrupa esses processos em três conjuntos: educação informal (os adultos transmitem os pré-construídos aos recém-chegados ao grupo), educação formal (dimensão didática e pedagógica) e transação social (interação entre pessoas já providas de pensamento consciente). Nossa pesquisa insere-se nesse terceiro conjunto.

\footnotetext{
${ }^{37}$ http://www.unige.ch/fapse/recherche/groupes/ssed/didactiques/grafe/ (consultado em 04/01/2016).
} 
O terceiro nível pretende analisar os processos de desenvolvimento, ou seja, os efeitos que a transmissão dos pré-construídos provoca sobre a constituição e o desenvolvimento do ser humano (BRONCKART, 2008, p.114). Esses efeitos são distribuídos por Bronckart (2005, 2008) nos seguintes campos: análise das condições de emergência do pensamento consciente; análise das condições do desenvolvimento, pensamento, conhecimentos e capacidades de agir e análise das contribuições individuais da pessoa para a transformação constante dos pré-construídos.

Sabendo disso e considerando que, para Bronckart (1999/2009), o ISD tem como objeto de estudo o agir humano, porém concentrando-se na análise das ações de linguagem materializadas em textos produzidos em um determinado contexto sociocultural, temos interesse em estudar o trabalho como forma de agir humano pelos textos produzidos pela professora participante do contexto desta pesquisa. Para tanto, mostraremos primeiramente como o ISD vê a questão do trabalho como forma de agir para, em seguida, tecer considerações sobre a relação entre linguagem e desenvolvimento e, finalmente, mostrar o modelo de análise textual desenvolvido pelo ISD.

\subsection{O agir, o trabalho como forma de agir e os textos produzidos em situação de trabalho}

Bronckart (2006, p.137) apresenta o termo "agir" com um sentido genérico: um comportamento ativo de um organismo. No entanto, comparado às outras espécies, o ser humano é o único a realizar um agir comunicativo com o auxílio de signos estruturados em textos, então, para essa espécie, é necessário distinguir um "agir geral” (agir não verbal) e um "agir comunicativo" ou "agir de linguagem" (agir verbal). Bronckart (2006) aponta que o agir geral humano pode ser apreendido pelas atividades coletivas, quer dizer, aquelas que organizam as interações entre o meio ambiente e o indivíduo. O agir de linguagem também deve ser apreendido sob a perspectiva do coletivo geral na forma de "atividades de linguagem", seu objetivo maior é garantir a realização das atividades gerais, auxiliando-as no seu planejamento, regulação e avaliação.

Sobre a relação agir e trabalho, os estudos de Lousada (2006), em diálogo com os de Bronckart (2004), apontam que, de acordo com o senso comum, o trabalho é considerado uma forma de agir. Além disso, esses autores nos mostram que, antes da 
criação do termo trabalho, devido à emergência do capitalismo industrial, havia apenas um termo que designava o trabalho e o agir.

Considerando a afirmação de que no trabalho o agir se manifesta de forma determinante (BRONCKART, 2004) e apoiando-se no interacionismo social, desenvolvido por Vygotski (1934/1997), que avalia a linguagem como fator fundamental para compreensão das atividades humanas, pode-se inferir que o desenvolvimento humano pode ser compreendido por meio da análise de textos produzidos em situação de trabalho. Isso porque, justamente, como aponta Bronckart (1999/2009, 2006, 2008), o agir não pode ser apreendido diretamente pela observação das condutas dos trabalhadores: ele só pode ser inferido a partir das representações construídas pelos trabalhadores nos textos por eles produzidos.

Sabendo da relação agir de linguagem e trabalho, apoiamo-nos na tripartição da relação trabalho/linguagem desenvolvida por Nouroudine (2002), mas proposta inicialmente por Johnson e Caplan (1979) e Lacoste (1995), segundo a qual as três modalidades são: "linguagem como trabalho", "linguagem sobre trabalho" e "linguagem no trabalho". Esses "três aspectos da linguagem estão em estreita relação como práticas linguageiras na situação de trabalho consideradas de maneira global; porém, cada um deles apresenta problemas de ordem prática e epistemológica bem distintos" (Nouroudine, 2002, p.18). Não pretendemos apresentar, aqui, uma longa explicação sobre cada uma dessas modalidades, mas propomos uma breve distinção entre elas.

A linguagem como trabalho é identificada "quando a linguagem é ela própria trabalho, isto é, funciona como parte legitimada da atividade" (Nouroudine, 2002, p.21). A respeito da linguagem no trabalho, ela é utilizada para conversar sobre assuntos diversos, não ligados ao trabalho (como por exemplo, sobre a vida pessoal de um ou de outro trabalhador). Já a linguagem sobre o trabalho está ligada à ideia de uma produção do saber sobre o trabalho, que é evocado para comentá-lo, avaliá-lo etc.

Considerando essas três modalidades da relação linguagem/trabalho, em nossa pesquisa, procuramos criar situações em que o professor produzisse textos sobre seu trabalho para que, a partir dessas verbalizações, pudéssemos ter acesso, sobretudo, à linguagem sobre o trabalho, analisando as representações (construídas nos textos orais e escritos) sobre sua situação de trabalho. Os textos produzidos em nossa pesquisa são: diários de aula e entrevistas (de instrução ao sósia), o que nos leva à questão dos gêneros textuais produzidos pelos professores em formação inicial ou contínua, já abordada por 
outros pesquisadores como Lousada (2013).

Ao falarmos em gêneros utilizados na formação de professores, parece-nos importante esclarecer o conceito no qual nos fundamentamos. O conceito de gêneros teve origem na Antiguidade, mas foi com os trabalhos de Mikhail Bakhtin (1953/1997) que ele foi redescoberto na era moderna, tendo passado por evoluções e modificações propostas por pesquisadores. Bronckart (1999/2009), autor no qual nos baseamos, parte da concepção inicial presente em Volochinov (1929) para seus estudos sobre os gêneros textuais. Segundo Bronckart (1999/2009, p.137, destaques do autor):

[...] na escala sócio-histórica, os textos são produtos da atividade de linguagem em funcionamento permanente nas formações sociais: em função de seus objetivos, interesses e questões específicas, essas formações elaboram diferentes espécies de textos, que apresentam características relativamente estáveis (justificando-se que sejam chamadas de gêneros de texto) e que ficam disponíveis no intertexto como modelos indexados, para os contemporâneos e para as gerações posteriores.

Portanto, de acordo com Bronckart (1999/2009), os textos, com os quais somos confrontados nas situações cotidianas, podem apresentar características similares no que diz respeito aos objetivos, intenções e outros aspectos ligados à sua produção, formando assim, "diferentes espécies de textos". Isso permite que os textos sejam organizados de acordo com suas semelhanças, em gêneros. Desse modo, podemos dizer que os gêneros são materializados por textos com características "relativamente estáveis". São essas regularidades que nos auxiliam com a produção de textos, permitindo que o conhecimento intuitivo dos gêneros já conhecidos ajude a produzir ou compreender textos adequadamente.

A respeito da característica dos gêneros que são "relativamente estáveis" (BRONCKART, 1999/2009, p.138), é preciso enfatizar que "os gêneros não podem nunca ser objeto de uma classificação racional, estável e definitiva" pelas seguintes razões (BRONCKART: 1999/2009, p.138):

Primeiro, porque do mesmo modo que as atividades de linguagem de que procedem, eles são em número tendencialmente ilimitado; segundo, porque os parâmetros que podem servir como critérios de classificação (finalidade humana geral, questão social específica, conteúdo temático, processos 
cognitivos mobilizados, suporte mediáticos, etc.) são, ao mesmo tempo pouco delimitáveis e em constante interação; enfim, e sobretudo, porque uma tal classificação não pode se basear no único critério facilmente objetivável, a saber, nas unidades linguísticas que neles são empiricamente observáveis.

Um dos gêneros textuais estudado nesta pesquisa é o diário de aula, caracterizado como um texto escrito pelo professor sobre suas impressões e reflexões após suas aulas. Construídos desse modo, esses textos são avaliativos sobre o trabalho educacional (MAZZILLO, 2004), portanto, são de interesse para o grupo de pesquisa ALTER-AGE, do qual esse estudo faz parte.

Machado (1998), que desenvolveu estudos sobre o gênero diário, explica que, quando utilizados em pesquisas educacionais, os diários são considerados não apenas como um instrumento de pesquisa, mas também como instrumento de ensino e aprendizagem. Apesar de admitir serem muitas as diferenças entre um diário e outro, a autora aponta algumas características gerais dos textos diaristas, são elas: "descontinuidade, heterogeneidade de conteúdos e de tratamento dos parâmetros da situação de comunicação, ausência de modelos fixos" (1998, p.29). Apesar da grande heterogeneidade desse gênero, Machado (1998, p.28) afirma predominar "o universo temático da experiência pessoal, incluindo-se aí ações, sentimentos, sensações e pensamentos relacionados a essa vivência".

Como estamos centrados nos diários produzidos pelo professor, consultamos Liberali (1999), que faz um levantamento de pesquisas que estudam o uso dos diários em formação contínua de educadores. Com o objetivo de investigar os diários e processos reflexivos em construção, a autora aponta, dentre as vantagens de sua utilização nesse contexto, aquelas que lhe parecem mais relevantes para seu estudo, e que consideramos para o nosso também. São elas (1999, p.26):

a) mostra questões recorrentes e importantes às análises dos praticantes (ButlerWall, 1979);

b) recupera a prática para a iniciação de uma reflexão sobre e na prática (Bartllet, 1990);

c) através de suas releituras, mostra padrões constantes, que apontam para características imperceptíveis num primeiro olhar (Bailey, 1990);

d) define uma filosofia pessoal de ensino, e reflete problemas sobre as construções feitas sobre o que é uma sala de aula e qual o papel do professor dentro dela (Deen, 1987);

e) oferece informações sobre como os educadores aprendem sobre sua prática e se desenvolvem sobre ela através de informações reunidas sobre a prática, a escola, 
a comunidade e é um veículo para a reflexão sistemática sobre a ação (Zeichner, 1981 \& 1987; Zeichner \& Liston, 1987a \& b);

f) torna os educadores metacognitivos sobre suas ações ao se definirem sobre o que sabem, o que sentem, o que fazem e por que o fazem (Zeichner, 1981);

g) guarda experiências significativas, ajuda o participante a entrar em contato e manter contato com seu autodesenvolvimento, oferece a oportunidade ao participante de se expressar de forma dinâmica e pessoal, forma uma base para a interação criativa (Richards, 1991);

h) auxilia a aprendizagem no relacionamento de conceitos novos e antigos, a articulação de idéias e experiências, e a criação de um modelo de formação centrado no educador (Porter et alii, 1990);

Embora, para a realização de seu estudo, Liberali (1999) tenha se baseado em outra vertente teórica, acreditamos que o que ela aponta sobre a função dos diários possa ser válida também para nossa pesquisa, sobretudo as vantagens: a, c, d, g.

Para analisar os textos pertencentes a diferentes gêneros textuais, Bronckart (1999/2009) propôs um modelo de análise textual que apresentaremos a seguir.

\subsection{O modelo geral de análise textual do ISD}

Esta seção está centrada na apresentação do modelo de análise textual do interacionismo sociodiscursivo (BRONCKART 1999/2009), utilizado para análise dos dados desta pesquisa, a saber: texto que orienta o trabalho da professora participante, seus diários de aulas e entrevistas de instrução ao sósia geradas por essa mesma professora.

De acordo com Bronckart (1999/2009) um texto tem uma "arquitetura textual” ou, em outras palavras, é organizado por um "folhado textual”, que é constituído por três camadas que estão superpostas, são elas: a infraestrutura geral do texto, os mecanismos de textualização e os mecanismos enunciativos. Em conformidade com Bronckart (1999/2009), apresentamos abaixo, brevemente, cada uma delas.

A infraestrutura geral do texto é o nível mais profundo da arquitetura interna dos textos. Essa camada é constituída por três formas de organização: a primeira é do plano geral/global do texto; a segunda forma de organização, dos tipos de discurso, designa os diferentes segmentos do texto (discurso interativo, discurso teórico, relato interativo e narração); a terceira forma de organização é das sequências (narrativa, descritiva, argumentativa, explicativa, dialogal, injuntiva, o script e a esquematização). 
Os mecanismos de textualização contribuem para o estabelecimento da coerência temática do texto, são compostos por três: conexão, coesão nominal e coesão verbal. A conexão é responsável por marcar as articulações da progressão temática. A coesão nominal possui a função de introduzir, retomar e substituir temas e personagens no texto. Por fim, é a coesão verbal que assegura a organização temporal e hierárquica dos processos presentes no texto com terminações verbais e advérbios.

Os mecanismos enunciativos colaboram para a manutenção da coerência pragmática do texto. Nesse último nível da arquitetura textual destacam-se as modalizações e as vozes. As modalizações avaliam alguns aspectos do conteúdo temático, enquanto as vozes, que não pertencem apenas a quem produz o texto, mas à diferentes pessoas/instituições, assumem o que é enunciado.

A seguir exibimos mais detalhadamente o modelo teórico-metodológico de análise textual do ISD. Para isso, apresentamos, primeiramente, o contexto de produção de textos e, em seguida, os três níveis de análise do folhado textual exibidos acima. Para melhor compreensão, utilizamos exemplos de uma análise que fizemos de um texto retirado do site da revista Nova Escola da editora Abril ${ }^{38}$, que se encontra em sua íntegra nos Anexos.

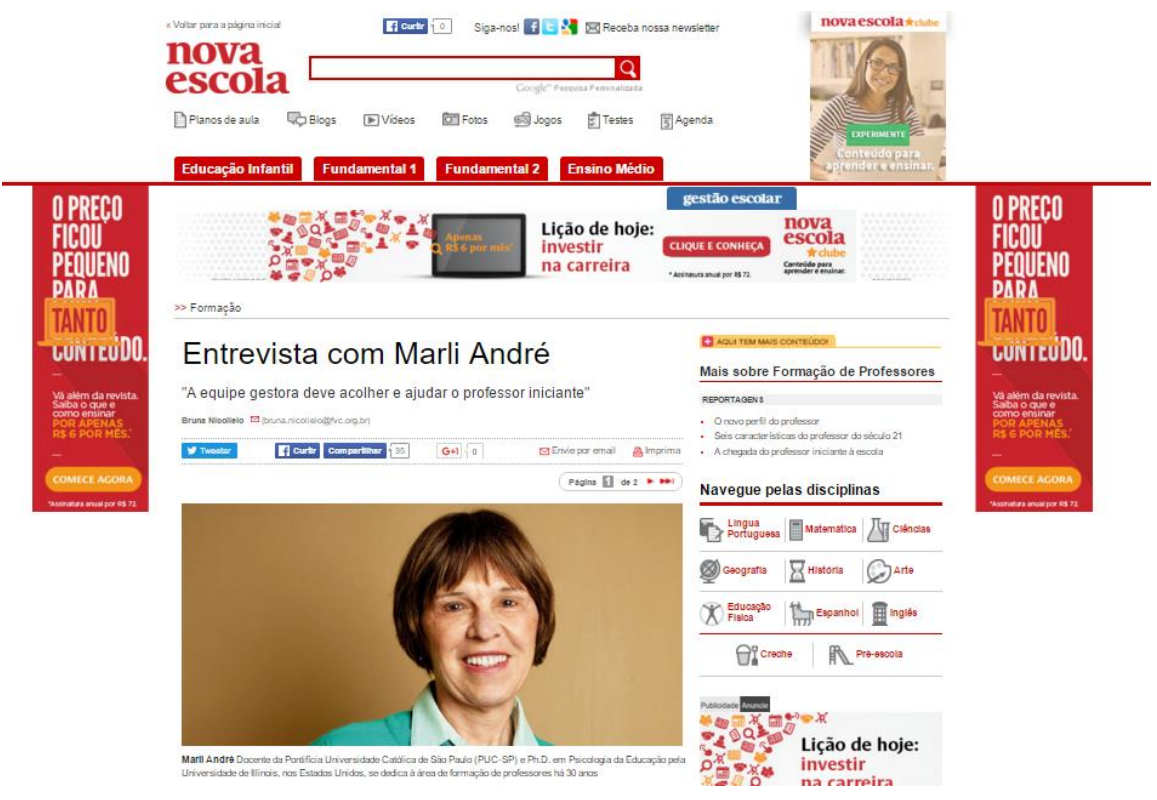

Figura 1: Captura de tela do site Nova Escola

\footnotetext{
${ }^{38} \mathrm{http}: / /$ revistaescola.abril.com.br/formacao/entrevista-marli-andre-763401.shtml?page $=0$ (consultado em $22 / 12 / 15)$
} 


\subsubsection{Contexto de Produção}

Bronckart (1999/2009) afirma que qualquer análise textual deve ser iniciada pela compreensão do contexto de produção do texto. Entende-se por contexto de produção "o conjunto dos parâmetros que podem exercer uma influência sobre a forma como um texto é organizado" (1999/2009, p.93). Assim, Bronckart (1999/2009) acentua somente fatores que desempenham uma "influência necessária" sobre a organização dos textos, isto é, que não seja uma influência mecânica. Nesse sentido, a análise textual consiste em reconstituir a situação de produção dos textos levando em consideração os fatores organizados em dois conjuntos: do mundo físico e do mundo social ou subjetivo.

Do ponto de vista físico, deve-se considerar que todo texto é resultado de um ato executado em um contexto físico. Nesse primeiro plano, objetiva-se verificar quatro parâmetros destacados abaixo (BRONCKART, 2009, p.93):

1) o lugar de produção: o local físico em que o texto foi produzido;

2) o momento de produção: a duração da produção do texto;

3) o emissor (produtor ou locutor): quem ou o que (máquina) produziu o texto oral ou escrito;

4) o receptor: quem pode perceber ou receber concretamente o texto.

Quando se trata de produção oral, normalmente o receptor e emissor estão em um mesmo espaço tempo, sendo assim, podem ser chamados, segundo Bronckart (1999/2009), de co-produtor ou interlocutor. Já em uma produção escrita, normalmente, o receptor e produtor não estão situados no mesmo espaço-tempo da produção. No caso de um receptor distante responder ao produtor (por carta, por exemplo), ele será seu interlocutor.

O segundo conjunto de fatores que influenciam a organização do texto leva em conta o contexto sociossubjetivo. A produção do texto se inscreve no quadro de uma forma de interação comunicativa (BRONCKART, 1999/2009), que implica o mundo social (normas, regras etc.) e o mundo subjetivo (imagem que o agente fornece de si ao agir). Esse conjunto também é decomposto em quatro parâmetros principais enumerados abaixo (BRONCKART, 1999/2009, p.94):

1) o lugar social: quadro do modo de interação em que o texto é produzido (escola, família, mídia, interação informal etc.)

2) a posição social do emissor (estatuto de enunciador): papel social assumido pelo emissor na interação (papel de pai, de professor, de cliente, de amigo etc.) 
3) a posição social do receptor (estatuto de destinatário): papel social conferido ao receptor (papel de colega, de aluno, de criança etc.)

4) o(s) objetivo(s): a intenção ou o que o enunciador pretende provocar no destinatário com o texto.

Abaixo apresentamos um exemplo de análise do contexto de produção de um texto retirado do site da revista Nova Escola da editora Abril.

Sobre o ponto de vista físico, o texto "Entrevista com Marli André" foi retirado da internet no site da revista Nova Escola. Não há indicação do momento de sua publicação, no entanto, consta a data de outubro de 2013 como versão impressa da edição 266 da revista Nova Escola. Sabendo disso, podemos afirmar que o texto analisado tem dois locais físicos de produção: o primeiro é a revista Nova Escola impressa e o segundo, a revista Nova Escola eletrônica. O texto analisado foi retirado do veículo eletrônico. O emissor do texto é a jornalista Bruna Nicolielo e seu receptor são leitores da revista Nova Escola impressa e digital interessados na temática do texto.

Do ponto de vista sociossubjetivo, o ambiente de interação no qual o texto foi produzido, isto é, seu lugar social é o site da revista Nova Escola, pertencente à mantenedora Editora Abril, Fundação Victor Civita (FVC). Para uma visão um pouco maior sobre o lugar social que abriga o texto analisado, consultamos o site da $\mathrm{FVC}^{39}$. A revista Nova Escola é reconhecida pela Organização das Nações Unidas para a educação, a ciência e a cultura (UNESCO) como o melhor veículo de Educação do país, sendo uma das maiores revistas de Educação do Brasil. A Nova Escola tem revistas impressas, desde sua fundação em março de 1986 e revistas digitais desde 2012. O site novaescola.org.br possui mais de 1 milhão de visitantes únicos por mês. Sabendo dessas informações sobre a revista, passemos para os enunciadores e destinatários do texto analisado.

O enunciador do texto é uma jornalista que não responde sozinha por sua produção, mas escreve em nome de uma instituição. Isso significa que existe um enunciador mais amplo - a revista Nova Escola da Editora Abril. Além disso, por se tratar de uma entrevista, o entrevistado do texto analisado também pode ser caracterizado como um dos enunciadores. Neste caso, as informações da entrevistada estão abaixo de sua foto: "Marli André Docente da Pontifícia Universidade Católica de São Paulo PUC-SP e Ph.D. em Psicologia da Educação pela Universidade de Illinois, nos Estados Unidos, se

\footnotetext{
${ }^{39}$ http://www.fvc.org.br (consultado em 23/12/2015).
} 
dedica à área de formação de professores há 30 anos”. O papel social desempenhado por essa enunciadora é de professora de uma universidade, o que nos mostra que ela não fala somente em seu nome, mas em nome de sua instituição. Além disso, as informações sobre a entrevistada indicam que Marli tem 30 anos de experiência sobre o assusto do texto. Isso dá credibilidade ao texto, já que a entrevistada é experiente nesse tema.

Por se tratar de uma revista chamada Nova Escola, na qual aborda temas sobre educação, os destinatários em geral são profissionais do ensino como professores e gestores (coordenadores pedagógicos, diretores etc.) de escolas. Esses profissionais estão evidenciados no trecho: "Saiba como sua escola pode conquistar isso" na capa da revista da edição 266 do texto analisado.

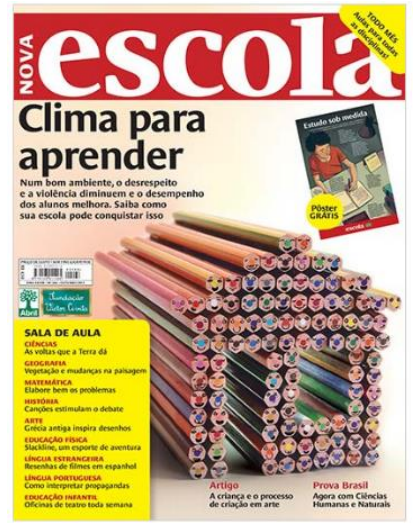

Figura 2: Capa da edição 266 da revista Nova Escola

Consideramos como destinatários do texto todos os profissionais da educação interessados em saber sobre o tema abordado. No entanto, acreditamos que dentro do grupo de destinatários gerais da revista, há os destinatários mais específicos do texto “Entrevista com Marli André”. Considerando o lead da entrevista: “A equipe gestora deve acolher e ajudar o professor iniciante", esses destinatários mais específicos podem ser, principalmente, os profissionais da equipe gestora, assim como, os professores iniciantes.

O objetivo principal do texto se apresenta no índice da revista eletrônica: "Marli André, professora da PUC-SP, conta as estratégias para integrar o jovem docente" e no lead: "A equipe gestora deve acolher e ajudar o professor iniciante". Além do objetivo principal, parece haver outros, principalmente porque dissemos que a entrevista possui mais de um enunciador, portanto cada enunciador pode ter objetivos mais particulares. A revista, por exemplo, pode ter como um de seus objetivos, buscar mais assinantes para as 
revistas impressas e eletrônicas, isso pode ser comprovado pela presença de propaganda de assinatura da revista na mesma página do texto analisado.

\subsubsection{Infraestrutura geral do texto}

O primeiro nível do folhado textual é constituído pelo plano geral do texto, pelos tipos de discurso e pelas sequências. Detalhamos cada um deles abaixo (BRONCKART, 1999/2009, p.120):

O plano geral diz respeito à organização do conjunto do conteúdo temático. É possível identificá-lo no processo de leitura e pode ser codificado em um resumo. O conteúdo temático de um texto é definido por Bronckart (1999/2009, p.97) “como o conjunto de informações que nele são explicitamente apresentadas, isto é, que são traduzidas no texto pelas unidades declarativas da língua natural utilizada”.

A partir dessas definições, propomos um exemplo de análise do plano geral do texto da revista Nova Escola. Antes disso, é preciso entender que o texto analisado é composto por:

- Título;

- Lead;

- Autoria;

- Corpo da reportagem:

$>$ Foto da entrevistada com suas informações principais;

$>$ Introdução da entrevista;

$>$ Onze questões com respostas sobre o tema.

- Propaganda de assinatura da revista;

- Local, número de edição e data de publicação da revista impressa e seu título original.

A respeito do plano global do texto, o título da entrevista é "Entrevista com Marli André", no entanto, no final deste mesmo texto há a informação de que o título original da versão impressa é “A equipe gestora deve acolher e ajudar o professor iniciante”. Esse título passou a ser o lead do texto digital, estudado por nós. Se o leitor não conhece a entrevistada, é impossível identificar qual será o assunto do texto apenas com a leitura do título, é o lead que apresentará ao leitor o tema da entrevista. 
$\mathrm{Na}$ introdução do texto, a jornalista apresenta um problema que será tratado no texto: apesar dos professores iniciantes chegarem às escolas com disposição e com vontade, eles enfrentarão vários desafios com pouco amparo da instituição, que não está sempre preparada para ajudar esses professores. Diante disso, são propostas onze questões a Marli André. A seguir, apresentamos um quadro com uma síntese do plano global dos conteúdos temáticos da entrevista e as questões referentes aos temas:

\begin{tabular}{|c|c|}
\hline $\begin{array}{c}\text { Questões da jornalista - introdução dos temas } \\
\text { abordados }\end{array}$ & Temas abordados \\
\hline $\begin{array}{l}\text { 1) O que define um professor iniciante? } \\
\text { 2) Qual é o perfil dos iniciantes no Brasil? }\end{array}$ & $\begin{array}{l}\text { Explicação e definição de professor iniciante e seu } \\
\text { perfil no contexto brasileiro. }\end{array}$ \\
\hline $\begin{array}{l}\text { 3) Quais as maiores frustrações de quem está no } \\
\text { início de carreira? } \\
\text { 4) A quem o jovem docente costuma recorrer para } \\
\text { pedir orientações? } \\
\text { 5) O que pode ser feito nas escolas para assegurar } \\
\text { a troca de experiências? }\end{array}$ & $\begin{array}{l}\text { Apresentação dos problemas enfrentados pelos } \\
\text { professores iniciantes; como eles tentam romper os } \\
\text { obstáculos e possíveis soluções. }\end{array}$ \\
\hline $\begin{array}{l}\text { 6) Qual a imagem que a equipe escolar costuma } \\
\text { fazer do jovem professor? }\end{array}$ & $\begin{array}{l}\text { Explicação sobre o perfil do professor iniciante do } \\
\text { ponto de vista da equipe escolar }\end{array}$ \\
\hline $\begin{array}{l}\text { 7) Do que depende a atração e a retenção dos } \\
\text { melhores profissionais nas salas de aula? } \\
\text { 8) Quais as descobertas de sua pesquisa mais } \\
\text { recente, ainda em curso, sobre a aproximação das } \\
\text { universidades com a escola na formação de } \\
\text { professores? } \\
\text { 9) O Pibid também altera o cenário de atratividade } \\
\text { da docência? } \\
\text { 10) As instituições de Ensino Superior também } \\
\text { estão sendo impactadas pelo programa? }\end{array}$ & $\begin{array}{l}\text { Relação da atração e retenção dos professores em } \\
\text { salas de aula com a formação inicial de futuros } \\
\text { professores; explicação do programa Pibid }\end{array}$ \\
\hline $\begin{array}{l}\text { 11) Há redes brasileiras com bons programas } \\
\text { voltados aos iniciantes? }\end{array}$ & $\begin{array}{l}\text { Exemplo de programa de incentivo ao professor } \\
\text { iniciante no Brasil }\end{array}$ \\
\hline
\end{tabular}

Os tipos de discurso são definidos por Bronckart (1999/2009, p.149, destaques do autor): "como formas linguísticas que são identificáveis nos textos e que traduzem a criação de mundos discursivos específicos". Os mundos discursivos são constituídos por dois subconjuntos de operações. O primeiro grupo revela a relação entre as coordenadas gerais que organizam o conteúdo temático de um texto e as coordenadas gerais do mundo ordinário (dos protagonistas da interação de linguagem). Assim, as coordenadas gerais podem ser disjuntas ou conjuntas das coordenadas do mundo ordinário da ação de 
linguagem. Quando disjuntas, as representações mobilizadas como conteúdos podem indicar fatos do passado, do futuro ou imaginados, sendo assim, pertencem aos mundos da ordem do narrar. Ao contrário, quando conjuntas, os fatos apresentados são acessíveis no mundo ordinário dos protagonistas da interação de linguagem. Ao invés dos fatos serem narrados, são mostrados, expostos, portanto são dos mundos da ordem do expor. $\mathrm{O}$ segundo subconjunto de operações do mundo discursivo diz respeito a relação que as instâncias de agentividade de um texto mantém com os parâmetros materiais da ação de linguagem (interlocutor e sua situação no espaço-tempo). O texto pode se apresentar em uma relação de implicação, quando há operações de explicitação da relação do produtor do texto com os parâmetros da ação de linguagem ou de autonomia, quando não há essa relação.

Bronckart (1999/2009) propõe uma combinação entre os dois subconjuntos de operações: de um lado a oposição entre a ordem do narrar e a ordem do expor, de outro lado, a oposição entre implicação e autonomia. O cruzamento dos subconjuntos revela quatro mundos discursivos (BRONCKART, 1999/2009, p.155):

1) mundo do expor implicado;

2) mundo do expor autônomo;

3) mundo do narrar implicado;

4) mundo do narrar autônomo.

Verifica-se nos mundos discursivos os tipos de discurso, sendo assim, concretizam-se: o discurso interativo no eixo do expor implicado, o discurso teórico no eixo do expor autônomo, o relato interativo no eixo do narrar implicado e a narração no eixo do narrar autônomo. Desse modo, os quatro tipos de discurso estão representados no quadro abaixo:

\begin{tabular}{|l|l|l|l|}
\cline { 3 - 4 } \multicolumn{2}{c|}{} & \multicolumn{2}{c|}{ Coordenadas gerais dos mundos } \\
\cline { 3 - 4 } \multicolumn{2}{c|}{} & $\begin{array}{l}\text { Conjunção } \\
\text { EXPOR }\end{array}$ & $\begin{array}{l}\text { Disjunção } \\
\text { NARRAR }\end{array}$ \\
\hline $\begin{array}{l}\text { Relação ao ato de } \\
\text { produção }\end{array}$ & IMPLICAÇÃO & Discurso interativo & Relato interativo \\
\cline { 3 - 4 } & AUTONOMIA & Discurso teórico & Narração \\
\hline
\end{tabular}


A seguir, para melhor entendimento sobre os tipos de discursos, apontaremos alguns exemplos, com base no texto de entrevista retirado do site Nova Escola.

Com relação aos tipos de discurso, verificamos no texto a alternância da conjunção ou disjunção da situação de produção do enunciador (expor ou narrar), assim como, da implicação ou autonomia do enunciador (implicado ou autônomo). Com exceção da narração, todos os outros tipos de discurso foram identificados em nosso texto. A seguir, apresentamos alguns exemplos:

- discurso interativo (mundo do expor implicado)

Quais as descobertas de sua pesquisa mais recente, ainda em curso, sobre a aproximação das universidades com a escola na formação de professores?

Nas cinco instituições universitárias em que estou fazendo o estudo, os graduandos têm experiências positivas: são bem acompanhados na escola por um educador experiente, que desempenha o papel de tutor, e recebem muitas informações sobre como atuar em sala de aula

Por pertencer ao gênero textual entrevista, o trecho acima é caracterizado por dois agentes (o entrevistador e a professora entrevistada) que alternam a tomada de turno em um mesmo espaço e tempo. A presença de elementos ligados diretamente aos agentes da interação (sua, estou) reafirma a implicação dos interlocutores no ato de produção. Além disso, o uso de verbos no presente do indicativo, por exemplo, indica que não há distância entre o mundo ordinário da interação e o mundo discursivo.

- discurso teórico (mundo do expor autônomo)

Não há consenso sobre isso. Muitos autores se baseiam no tempo de docência e defendem que os três primeiros anos são considerados os mais difíceis para quem está começando

O discurso teórico caracteriza-se pela ausência do agente de produção, apresentando autonomia em relação ao ato de produção. Observa-se ainda que não há distância entre o mundo discursivo e o mundo ordinário, assim como indicam os verbos no presente do indicativo.

- relato interativo (mundo do narrar implicado)

Em minha pesquisa anterior (O Papel das Práticas de Licenciatura na Constituição da Identidade Profissional de Futuros Professores), realizada antes do Pibid, identifiquei que os estagiários tinham grandes dúvidas sobre permanecer ou não na carreira. 
Neste exemplo, percebemos a distância entre os fatos narrados e o momento da produção do texto. Essa distância é marcada pelos tempos verbais, neste caso o pretérito perfeito e o organizador temporal (antes). Nota-se também a implicação do enunciador no ato de produção, caracterizada, nesse excerto, pelo verbo conjugado em primeira pessoa do singular (identifiquei) e pronome possessivo (minha).

Não identificamos o tipo de discurso narração no texto. Apesar da presença de tempos verbais e organizadores temporais indicando o passado (mundo do narrar), o texto não apresenta uma relação de autonomia com produtor do texto. Sendo assim não há a relação dos mundos do narrar autônomo.

As sequências são outra dimensão da infraestrutura textual, têm como função organizar de modo linear ou sequencial o conteúdo temático. As sequências podem ser: narrativa, descritiva, argumentativa, explicativa, dialogal, injuntiva, o script (grau zero da sequência narrativa) e a esquematização (grau zero das sequências argumentativa e explicativa). Com base nos estudos de Adam (1992), Bronckart (1999/2009, p.218) define as sequências como "unidades estruturais relativamente autônomas, que integram e organizam macroproposições, que por sua vez, combinam diversas proposições, podendo a organização linear do texto ser concebida como o produto da combinação e da articulação de diferentes tipos de sequências". Considerando que Bronckart (1999/2009) compreende a noção de macroproposição pela noção de fase, a seguir, descrevemos, brevemente, os protótipos, ou seja, "construtos teóricos" de cada sequência explicitada por Bronckart (1999/2009), apoiado nos estudos como o de Labov e Waletzky (1996), Grize (1981b) e, sobretudo, de Adam (1992).

a) narrativa: só há sequência narrativa quando a organização da história é sustenta por um recurso de intriga, que seleciona e organiza os acontecimentos para formar um todo com início, meio e fim. Nesse sentido, o modelo de sequência narrativa proposto por Bronckart (1999/2009, p.220), a partir de Adam (1992), Labov e Waletzky (1996), é constituído pelas seguintes fases de sucessão obrigatória: fase de situação inicial (exposição do estado de coisas “equilibrado"), fase de complicação (cria uma tensão), fase de ações (reúne os acontecimentos desencadeados), fase de resolução (redução da tensão), fase de situação final (explicita o novo estado de equilíbrio). Bronckart (1999/2009, p.221) acrescenta mais duas fases menos restritas na posição da sequência, são elas: fase de avaliação (comentário sobre o desenrolar da história) e fase da moral (significação global da história). 
b) descritiva: diferentemente da sequência narrativa, as fases da sequência descritiva não se organizam de forma linear obrigatória, o que ocorre é uma combinação de fases que se encaixam em ordem hierárquica ou vertical. Essa sequência é composta por três fases principais: fase de ancoragem (tema da descrição), fase de aspectualização (aspectos do tema são enumerados) e a fase de relacionamento (elementos descritos assimilados a outros) (BRONCKART, 1999/2009, p.222-223).

c) argumentativa: o protótipo da sequência argumentativa apresenta-se em quatro fases: fase de apresentação de argumentos (elementos que orientam para uma conclusão), fase de apresentação de contra-argumentos (restrição à orientação argumentativa) e fase de conclusão ou de nova tese (soma os efeitos dos argumentos e contra-argumentos) (BRONCKART, 1999/2009, p.227).

d) explicativa: o protótipo da sequência explicativa é composto por quatro fases: fase de constatação inicial (introduz um fenômeno não contestável), fase de problematização (explicita uma questão da ordem do porquê ou do como, de contradição), fase de resolução (introduz elementos para responder às questões) e fase de conclusãoavaliação (reformula e completa a constatação inicial) (BRONCKART, 1999/2009, p.229).

e) dialogal: essa sequência se apresenta apenas em segmentos de discurso interativo dialogado, suas três fases gerais são: fase de abertura (os interactantes entram em contato), fase transacional (o conteúdo temático é co-construído) e fase de encerramento (fim da interação) (BRONCKART, 1999/2009, p.231).

f) injuntiva: na sequência injuntiva o agente produtor pretende fazer $o$ destinatário agir. É caracterizada por verbos no imperativo ou no infinitivo e ausência de elemento espacial ou hierárquico (BRONCKART, 1999/2009, p.237).

g) script: no script, as sequências dos acontecimentos e ações da história são dispostas em ordem cronológica, mas não há nessa organização um processo de tensão. Considera-se, portanto, que o script constitui grau zero da planificação dos seguimentos da ordem do narrar (BRONCKART, 1999/2009, p.238).

h) esquematização: a organização dos segmentos na esquematização se realiza de forma não convencional, mas por meio de esquematização como por exemplo: enumeração, definição, enunciado de regras etc. (BRONCKART, 1999/2009, p.239).

A análise do texto da revista do site da Nova Escola com o modelo do ISD, permitiu observar que as sequências textuais predominantes no texto analisado são as 
sequências dialogal e explicativa, visto que a entrevista é estruturada em seguimentos do discurso interativo e a professora entrevistada tem o papel de explicar o que lhe é perguntado, demonstrando sua opinião sobre os fatos. Abaixo, apresentamos os protótipos dessas duas sequências:

O protótipo da sequência dialogal do texto analisado pode ser representado da seguinte forma:

- fase de abertura: considerando que se trata de uma entrevista escrita em uma revista, a fase de abertura corresponde a uma introdução do tema abordado:

\section{O que define um professor iniciante?}

MARLI ANDRÉ Não há consenso sobre isso [...]

- fase transacional: o conteúdo temático é co-construído ao longo da entrevista, sendo que, o entrevistador é quem vai guiando os assuntos abordados no texto, com suas perguntas, e o entrevistado não apenas responde, mas também explica o assunto, já que é o interlocutor que mais desenvolve os conteúdos. A partir da introdução do tema central - o início da carreira de professor, a entrevista vai desenvolvendo-se, delineando o perfil desses professores no Brasil, as dificuldades por eles enfrentadas no contex to de trabalho, as possíveis soluções e o que já tem sido feito como melhorias.

- fase de encerramento: nesta fase, mostra o que já é feito no Brasil, para melhorar as condições dos professores no início do trabalho docente.

O protótipo da sequência explicativa do texto analisado pode ser representado da seguinte forma:

- fase de constatação inicial: "A equipe gestora deve acolher e ajudar o professor iniciante";

- fase de problematização: "Mas isso não acontece nas redes de modo formal e com a frequência desejável”

- fase de resolução: "É possível criar grupos de tutoria nos quais cada jovem educador passa a receber a orientação de um colega que tem mais tempo de docência. Outra possibilidade é organizar periodicamente reuniões para que seja realizada a discussão da prática de sala de aula"

- fase de conclusão-avaliação: Existem pouquíssimas iniciativas dessa natureza. Uma delas acontece em Sobral (a 248 quilômetros de Fortaleza). Nesse município, segundo a lei, o profissional que está começando recebe $25 \%$ de salário a mais todos os meses para participar de um curso de formação durante o estágio probatório (...)”. 
Como parte desta pesquisa é composta por dados orais, na entrevista de Instrução ao Sósia, a sequência predominante que encontramos foi a dialogal. Sendo assim, seguindo as próprias orientações de Bronckart (2010), procuramos complementar o modelo de análise com alguns conceitos mais específicos desenvolvidos por Marcuschi (2001) sobre a análise da conversação. O autor define cinco características básicas da conversação, são elas (MARCUSCHI, (2001, p.15):

1) interação entre pelo menos dois falantes;

2) ocorrência de pelo menos uma troca de falantes;

3) presença de uma sequência de ações coordenadas;

4) execução numa identidade temporal;

5) envolvimento numa "interação centrada".

Com base nessas cinco características básicas, Marcuschi (2001), em conformidade com Dittmann (1979), afirma que "tais características permitem-nos tomar a conversação como sendo uma interação verbal centrada, que se desenvolve durante o tempo em que os dois ou mais interlocutores voltam sua atenção visual e cognitiva para uma tarefa comum" (2001, p.15).

A partir da definição das características da conversação, Marcuschi (2001) propõe o estudo de suas operações, acentuando a importância de organizadores como: a tomada de turno, as falas simultâneas ou sobrepostas, as pausas, os silêncios e as hesitações. A respeito da tomada de turnos, Sacks, Schgloff e Jefferson (1974 apud MARCUSCHI, 2001) montam um modelo elementar para a conversação, em que consideram a tomada de turno uma operação básica da conversação e o turno, um dos componentes centrais do modelo. Sendo assim, segundos esses autores, qualquer comunicação será apresentada da seguinte forma (SACKS, SCHGLOFF, JEFFERSON, 1974 apud MARCUSCHI, 2001, p.18):

\footnotetext{
a) a troca de falantes recorre ou pelo menos ocorre;

b) em qualquer turno, fala um de cada vez;

c) ocorrências com mais de um falante por vez são comuns, mas breves;

d) transições de um turno a outro sem intervalo e sem sobreposição são comuns; longas pausas e sobreposições extensas são a minoria;

e) a ordem dos turnos não é fixa, mas variável;

f) o tamanho do turno não é fixo, mas variável;
} 
g) a extensão da conversação não é fixa nem previamente especificada;

h) o que cada falante dirá não é fixo nem previamente especificado;

i) a distribuição dos turnos não é fixa;

j) o número de participantes é variável;

1) a fala pode ser contínua ou descontínua;

m) são usadas técnicas de atribuição de turnos;

n) são empregadas diversas unidades construidoras de turno: lexema, sintagma, sentença etc.

o) certos mecanismos de reparação resolvem falhas ou violação das tomadas.

Se o turno é considerado como uma das unidades centrais da organização conversacional, a tomada de um turno, ou seja, a passagem de um turno para outro, tem papel fundamental. Para Marcuschi (2001) a tomada de turno não se dá de forma caótica, mas obedece técnicas e regras. Indicamos, a seguir, duas técnicas, segundo Sacks, Schgloff e Jefferson (1974 apud MARCUSCHI, 2001, p.20) do mecanismo de tomada de turno:

Técnica I: o falante corrente escolhe o próximo falante, e este toma a palavra iniciando o próximo turno;

Técnica II: o falante corrente para e o próximo falante obtém o turno pela autoescolha.

Existem algumas regras para a operação dessas técnicas, a saber: o falante corrente escolhe um próximo falante pela técnica I; o falante corrente não escolhe a técnica I, então qualquer participante pode autoescolher-se pela técnica II; o falante corrente não escolhe o próximo e nenhum outro falante se autoescolhe, então o falante pode prosseguir falando; se o falante prosseguir falando, então as regras anteriores replicam-se até que se opere a transição (MARCUSCHI, 2001).

Outro fator importante sobre a organização conversacional são as falas simultâneas e as sobreposições de vozes. Marcuschi (2001, p.25) faz a seguinte distinção entre elas: i) fala simultânea: dois turnos superpostos e ii) sobreposição de vozes: a fala durante o turno de outro. O surgimento de falas simultâneas pode se verificar quando ocorre a autoescolha do próximo falante, assim ocorre sucessivamente: a) alguém toma a palavra; b) ninguém toma a palavra; c) ocorre a múltipla autoescolha. Quando acontece a fala simultânea, há alguns marcadores metalinguísticos que podem aparecer, como: 
"espera aí", "deixe eu falar”, "é a minha vez”, “um momento minha gente”, “depois você fala", "licença", "por favor" etc. A respeito da sobreposição de vozes, uma das formas mais comuns de se dar é quando o ouvinte concorda, discorda, endossa etc. o falante com produções como: “sim”, “tá bom”, “é”, “ahã”, “claro” etc.

Também são organizadores importantes, conforme Marcuschi (2001), as pausas, os silêncios e as hesitações. As pausas são vistas de diferentes modos, dependendo da sua posição estrutural. Apoiado em Rath (1979), Marcuschi (2001, p.63) propõe a seguinte divisão das pausas:

\section{1) pausas sintáticas:}

a) de ligação: funcionam para construção interna da unidade, sem iniciar uma nova. Podem vir no lugar de conectores (“e”, "então", "mas" etc.)

b) de separação: servem para separar ou delimitar unidades comunicativas, aparecem após um sinal de fechamento de unidade ou baixamento de tom de voz

\section{2) pausas não-sintáticas:}

a) de hesitação: podem ser idiossincráticas ou estarem servindo para o planejamento verbal, têm motivação principalmente cognitiva

b) de ênfase: são sinalizadores do pensamento, que o reforçam ou chamam a atenção, aparecem, muitas vezes, entre o artigo e o nome ou no interior de um sintagma

A diferença entre a hesitação e os outros sinais está no fato dos fenômenos da hesitação serem caracterizados como "indicadores da esfera do planejamento cognitivo do texto" (MARCUSCHI, 2001, p.64). As hesitações ou pausas preenchidas são definidas por Marcuschi como momentos que servem para (2001, p.27):

\footnotetext{
organização e planejamento interno do turno e dão tempo ao falante de se preparar. São muitas as formas de se manifestarem, mas geralmente são reduplicações de artigos, de conjunções ou mesmo de sons não lexicalizados, como "ah ah ah" ou "ah:: eh::" e outros. Às vezes funcionam para o ouvinte como um pedido de socorro.
}

No que diz respeito ao silêncio, Marcuschi (2001) diz que se ele aparecer após uma pergunta pode ser encarado como um desconhecimento de resposta, no caso, por exemplo, do silêncio em uma sala de aula, após uma pergunta do professor. Outro 
exemplo mostrado por esse autor é quando o silêncio é encarado como uma resposta interpretada pelo parceiro da conversação, nesse caso o silêncio é interpretado como um turno. Marcuschi (2001, p.28) exibe um exemplo desse caso:

L. A. M. - Recife - 1984

(Contexto: I. e N. falavam a propósito de uma discussão que N. tivera com outras pessoas.)

I: por que você não disse pra ele que você era contra"

$\mathrm{N}$ : (3.0) ((permanece de cara fechada))

I: então tu é a favor é"

N: ((dando uma banana)) tá aqui a favor,

I: então tu tava com medo é"

\subsubsection{Mecanismos de textualização}

O segundo nível do folhado textual está ligado à coerência global dos textos, sendo constituído pelos mecanismos de textualização formados pela conexão, coesão nominal e coesão verbal.

Para melhor entendimento da função dos mecanismos de textualização, propomos uma definição de texto, segundo Bronckart (1999/2009, p.259, grifo nosso), um texto "constitui um todo coerente, uma unidade comunicativa articulada a uma situação de ação e destinada a ser compreendida e interpretada como tal por seus destinatários". A respeito dessa coerência geral, os mecanismos de conexão marcam as relações entre as articulações da progressão temática, realizadas por organizadores textuais. Por sua vez, os mecanismos de coesão marcam as relações de dependência ou descontinuidade dos constituintes que são internos às estruturas de frases (BRONCKART, 1999/2009).

A partir dessa distinção, expomos como são marcadas essas relações. A marcação dos mecanismos de conexão é feita por unidades linguísticas, que são agrupadas em quatro categorias:

a) subconjunto de advérbios ou de locuções adverbiais (de fato, depois, primeiramente etc.)

b) subconjunto de sintagmas preposicionais (depois de três dias..., para concretização desse projeto..., para realizar esse projeto... etc.)

c) as coordenativas (e, ou, nem, mas etc.) 
d) as subordinativas ou conjunções de subordinação (antes que, desde que, porque etc.)

A marcação dos mecanismos de coesão nominal é feita por sintagmas nominais ou pronomes, estabelecendo como função introduzir uma unidade de significação nova ou retomar essa "unidade-fonte" no texto (BRONCKART, 1999/2009). Já os mecanismos de coesão verbal são marcados pela escolha dos constituintes dos sintagmas verbais.

$\mathrm{Na}$ entrevista analisada, podemos destacar como conexão as conjunções coordenativas e de subordinação explicativas, utilizadas pelo produtor para explicar suas ideias, opiniões, como por exemplo: que, porque, ou seja:

As instituições de Ensino Superior também estão sendo impactadas pelo programa?
MARLI Sim. Os futuros docentes estão exigindo mais da estrutura universitária. Quem leciona relata
que os estudantes dão trabalho: eles perguntam muito e querem mais materiais para estudar. Ou seja, o
Pibid está proporcionando a formação continuada dos docentes do Ensino Superior, porque eles
precisam se atualizar cada vez mais para atender os alunos.

A respeito da coesão nominal, a entrevista é marcada pelo uso de anáforas que se referem ao sujeito pertencente ao tema da entrevista: o professor iniciante. Assim, podemos citar como exemplos: "jovem”, "novato", “jovem docente”, “jovem educador”, “jovem professor", “o aprendiz” etc.

Como vimos, a coesão verbal colabora com as relações de continuidade do texto. Por se tratar de uma entrevista, constituída pelo discurso interativo, predominam no texto verbos e locuções verbais no presente do indicativo:

\footnotetext{
Ele geralmente não é visto pelos colegas que têm mais tempo de carreira como o aprendiz que de fato é, alguém que precisa de apoio e estímulo. A maioria o julga um profissional idealista. Os pais da criançada também não se sentem seguros diante de um educador muito jovem. Ele, por sua vez, encara os colegas como pessoas acomodadas, que não são inovadoras.
}

\subsubsection{Mecanismos enunciativos}

No terceiro e último nível do folhado textual, localizamos os mecanismos enunciativos, que contribuem para a coerência pragmática dos textos, revelando "as diversas avaliações (julgamentos, opiniões, sentimentos) que podem ser formuladas a respeito de um ou outro aspecto do conteúdo temático" (BRONCKART, 1999/2009, 
p.319), assim como, "as fontes dessas avaliações" (2009, p.319). Nesse sentido, consideramos, respectivamente, as modalizações e as vozes.

As modalizações têm por finalidade manifestar diferentes comentários ou avaliações a respeito dos elementos do conteúdo temático. Sendo assim, Bronckart (1999/2009, p.330) redefine a teoria dos três mundos de Habermas para propor quatro funções de modalização:

a) as modalizações lógicas: são apoiadas em critérios ou conhecimentos; os elementos do conteúdo são apresentados como fatos atestados (ou certo), possíveis, prováveis eventuais, necessário etc. Por exemplo: “卓 evidente que a teoria filosófica da opinião como saber de segunda ordem suporia a existência (as matemáticas serviram de paradigma) de um saber certo" (BRONCKART, 1999/2009, p.331, grifo do autor);

b) as modalizações deônticas: são apoiadas nos valores e opiniões; os elementos do conteúdo temático são apresentados como sendo do domínio do direito, da obrigação social e/ou da conformidade com as normas. Por exemplo: "Semelhante advertência era necessária e jamais deve ser esquecida, pois a agitação suscitada pelo 'espinosismo' exerceu..." (BRONCKART, 1999/2009, p.331, grifo do autor);

c) as modalizações apreciativas: avaliam os elementos do conteúdo temático, apresentando-os como estranhos, infelizes, felizes etc. Por exemplo: "Tentava escrever um poema sobre Angélica Pabst. Infelizmente, versos de W. B. Yeats não cessavam de se interpor entre ele e sua musa, e não achou nada melhor do que adaptá-los a seu próprio caso" (BRONCKART, 1999/2009, p.332, grifo do autor);

d) as modalizações pragmáticas: são apoiadas em aspectos de responsabilidade de uma entidade do conteúdo temático (personagem, grupo); atribuem a esse agente intenções, razões, capacidades de ação. Por exemplo: "Seus dentes rangiam, ela estava cinza: quis dar um passo em direção à janela em busca de um pouco de ar, mas não pôde senão estender os braços, as pernas the faltaram e ela caiu sobre o sofá" (BRONCKART, 1999/2009, p.332, grifos do autor).

Dessas quatro modalizações apresentadas por Bronckart (1999/2009), identificamos três delas na análise da entrevista da revista Nova Escola. São elas: 
a) as modalizações lógicas

Também é essencial um bom ambiente de trabalho na escola e isso diz respeito a muitas coisas: infraestrutura, relações entre a equipe e a comunidade e ainda meios de que a instituição dispõe para valorizar e ajudar o corpo docente - por exemplo [...]

b) as modalizações deônticas:

A equipe gestora deve acolher e ajudar o professor iniciante $O$ que pode ser feito nas escolas para assegurar a troca de experiências? MARLI Elas precisam institucionalizar essa prática.

[...]o Pibid está proporcionando a formação continuada dos docentes do Ensino Superior, porque eles precisam se atualizar cada vez mais para atender os alunos.

c) as modalizações apreciativas:

MARLI Os dados obtidos até agora revelam coisas boas para o futuro da docência no país. Vamos ter profissionais mais bem formados por causa do Programa Institucional de Bolsa de Iniciação à Docência (Pibid)

Quanto às vozes, sabemos que, usando as palavras do autor, "podem ser definidas como as entidades que assumem (ou às quais são atribuídas) a responsabilidade do que é enunciado" (BRONCKART, 1999/2009, p.326). Bronckart (1999/2009) explica que na maioria dos casos, a responsabilidade do dizer é, por exemplo, do próprio narrador ou expositor do texto (dependendo do tipo de discurso). Essa voz pode ser chamada de neutra. No entanto, existem outras vozes que permeiam os textos, essas vozes secundárias podem ser reagrupadas em três categorias gerais, como proposto por Bronckart (1999/2009, p.327):

a) as vozes de personagens: são procedentes de seres humanos ou entidades humanizadas; esses agentes estão implicados nas ações ou acontecimentos que constituem o conteúdo temático.

b) as vozes sociais: são procedentes de personagens, grupos ou instituições que não estão implicados como agentes no percurso temático, sendo assim, são indicados como instâncias externas do conteúdo.

c) a voz do autor: é a voz que aparece da própria pessoa que produz o texto para avaliar alguns aspectos do que é enunciado.

Para aprofundarmos o estudo dos mecanismos enunciativos, baseamo-nos em Maingueneau (2011) que estuda a noção de polifonia em textos, para analisar a presença de várias vozes identificadas simultaneamente em enunciados. Essas diferentes vozes podem se apresentar por meio de alguns recursos, tais como: discurso direto, discurso direto livre, discurso indireto, discurso indireto livre, aspas, itálico, modalização 
autonímica, provérbio etc. No entanto, para esse estudo, concentramo-nos na modalização autonímica e provérbio.

Para definir os provérbios no campo da polifonia, usamos os termos de Maingueneau (MAINGUENEAU, 2011, p.169-170):

\begin{abstract}
A enunciação proverbial é fundamentalmente polifônica; o enunciador apresenta sua enunciação como uma retomada de inumeráveis enunciações anteriores, as de todos os locutores que já proferiram aquele provérbio. Não se trata, porém, de uma citação no sentido habitual do termo, como ocorre, por exemplo, no discurso direto. Proferir um provérbio ("Quem tudo quer, tudo perde", "Tal pai, tal filho" etc.) significa fazer com que seja ouvida, por intermédio de sua própria voz, uma outra voz, a da "sabedoria popular", à qual se atribui a responsabilidade pelo enunciado. $\mathrm{O}$ enunciador não explicita a fonte desse enunciado: cabe ao co-enunciador identificar o provérbio como tal apoiando-se, ao mesmo tempo, nas propriedades linguísticas do enunciado e em sua própria memória.
\end{abstract}

Com base nessa definição, Maingueneau (2011) expõe os fatores que apoiam o co-enunciador a identificar o provérbio: sua memória e algumas propriedades linguísticas. A respeito da memória, o autor esclarece que "o provérbio pertence a um estoque de enunciados conhecidos como tal pelo conjunto de falantes de uma língua" (2011, p.171), é pressuposto, então, que os falantes, assim como conhecem o léxico da sua língua, conheçam os provérbios. Sobre as propriedades linguísticas, apresentamos algumas de suas características, em conformidade com Maingueneau (2011), no entanto com exemplos de provérbios brasileiros. Assim, os provérbios, normalmente, são: curtos e binários (Tal pai/tal filho"), têm frequentes rimas ("Deus ajuda quem cedo madruga"), com simetrias sintáticas ou semânticas entre as partes ("A verdade é amarga, a mentira é doce"), formados por palavras arcaicas ("Viúva rica com um olho chora e com outro repenica") etc.

Quanto ao enunciador do provérbio, Maingueneau (2011) considera-o corresponsável "na medida em que a 'sabedoria popular' é, na realidade, a própria comunidade dos locutores de uma língua" (2011, p.170).

O emprego da modalização autonímica, de acordo com Maingueneau (2011), permite que o enunciador comente sua própria fala durante seu discurso. Para 
exemplificar essa definição o autor utiliza o seguinte excerto (MAINGUENEAU, 2011, p.158):

“A TV naquele tempo não atraía a presença do auditório junto aos estúdios e aquele modesto estúdio da rue Cognacq-Jay tinha um aspecto lamentável. Essa 'boemia televisiva' me faz lembrar de Charles Aznavour"

Diante desse exemplo, vemos que o enunciador ao colocar entre aspas boemia televisiva, propõe um comentário sobre o enunciado. Usando as palavras de Maingueneau a respeito disso (2011, p.158, grifos do autor):

\footnotetext{
Esse tipo de emprego é um exemplo de modalização autonímica, que se caracteriza por englobar o conjunto de procedimentos por meio dos quais o enunciador se desdobra, de uma certa maneira, seu discurso para comentar sua fala enquanto está sendo produzida. Ao comentar sua própria fala o enunciador produz uma espécie de enlaçamento na enunciação.
}

Authier-Revuz (1998), autora que defende a ideia de que a fala é determinada de fora do sujeito, foi a primeira a propor o conceito de modalização autonímica, a partir do qual Maingueneau desenvolve seus estudos. A respeito do que Maingueneu (2011) determina como "comentários do enunciador sobre sua própria enunciação", a autora denomina-os de "não-coincidências do dizer" e classifica "quatro campos de "nãocoincidência' ou de heterogeneidade que o dizer se representa como localmente 'confrontado' com pontos em que, assim 'alterado', ele se desdobra" (AUTHIERREVUZ, 1998, p.20). Nesse sentido, essas quatro categorias são (AUTHIER-REVUZ, 1998, p.20-21, grifos da autora):

\footnotetext{
a) não-coincidência interlocutiva entre os dois co-enunciadores;

b) não-coincidência do discurso consigo mesmo, afetado pela presença em si de outros discursos;

c) não-coincidência entre as palavras e as coisas;

d) não-coincidência das palavras consigo mesmas, afetadas por outros sentidos, por outras palavras, pelo jogo da polissemia, da homonímia etc.
}

No caso da categoria da não-coincidência do discurso consigo mesmo, AuthierRevuz (1998) considera que entre as palavras do enunciador há a presença de palavras de 
um outro discurso, pois, de acordo com o dialogismo bakhtiniano, "toda palavra que, por se produzir no 'meio' do já-dito dos outros discursos, é habitada pelo discurso outro" (1998, p.22, grifos da autora). Nesse sentido, a autora determina o discurso como marcado por uma "fronteira interior/exterior", ou seja, entre si e o outro. Diante de certo número dessas oposições, Authier-Revuz (1998) propõe alguns "tipos de fronteiras entre si e o outro, pelas quais um discurso produz em si mesmo" (AUTIER-REVUZ, 1998, p.23, grifos da autora):

( 1) balizagem ou incerteza do traçado (desde o elemento "citado" com todas as precisões, até a retomada não marcada); (2) exterior "apropriado" ao objeto do dizer (isto é, em que uma palavra "não de si" se impõe como palavra "disto do qual se fala"; por exemplo: palavra de um outro lugar, de uma outra época, de uma outra teoria, de uma outra pessoa, da qual se fala, e que se impõe como apropriada a esse objeto) vs. associado ao discurso (isto é, que se impõe em apoio, conflito, associação de idéias ... ao discurso, a partir do campo de força do interdiscurso ); (3) maneira de dizer outra tomada como "roupagem" outra para um mesmo conteúdo vs. como ponto de vista outro sobre o real; (4) exterioridade de uma palavra ou do sentido de uma palavra $(X$, no sentido cristão, no sentido de Bourdieu); (5) tipo de outro: outra língua, região, época, registro, "socioleto", discurso teórico, posição política ...; (6) o exterior do repetido no singular (imagens da relação com a estereotipia); ...

Apoiamo-nos nesses conceitos, referentes às modalizações e vozes, para apresentar um exemplo de análise do texto "Entrevista com Marli André", que foi retirado da internet no site da revista Nova Escola. Na entrevista analisada duas vozes são bem evidentes, elas pertencem às enunciadoras do texto: a voz da entrevistadora, nas questões do texto, e a voz da entrevistada, nas respostas às perguntas, ambas as vozes compreendem vozes das instituições nas quais cada uma delas trabalha (voz da revista Nova Escola e voz da universidade PUC-SP). A introdução é marcada por um exemplo de polifonia, em que há as vozes das enunciadoras, mas também a voz do senso comum, pois não tem embasamento nas respostas da entrevistada, que enuncia: "Todos os anos, milhares de jovens entram pela primeira vez em uma sala de aula para lecionar".

Além dessas vozes, identificamos também a voz dos professores iniciantes, indicadas pela entrevistada, introduzidas pelo discurso direto, materializado pelo verbo discendi dizer e aspas: 
Prova disso é ser comum encontrar novatos dizendo: "Mesmo com todos os problemas que enfrento, ver o brilho nos olhos dos alunos quando eles aprendem é o que me faz continuar lecionando"

O programa está até atraindo os jovens que não tinham o ensino como primeira opção profissional. Eles dizem: "Nunca pensei em ser professor, mas, depois que comecei a participar desse programa, eu quero!"

Os mecanismos enunciativos compreendem também as modalizações. Nesta entrevista, damos destaque às modalizações deônticas, que se apoiam em opiniões do mundo social para avaliar os elementos do conteúdo temático. A seguir apresentamos, como exemplo, o lead da entrevista, que pode ser interpretado como o tema da entrevista, e mais dois exemplos:

A equipe gestora deve acolher e ajudar o professor iniciante

O que pode ser feito nas escolas para assegurar a troca de experiências?

MARLI Elas precisam institucionalizar essa prática.

[...]o Pibid está proporcionando a formação continuada dos docentes do Ensino Superior, porque eles precisam se atualizar cada vez mais para atender os alunos.

Para complementar o estudo de vozes, haja vista nosso conjunto de dados orais as entrevistas de instrução ao sósia, apresentamos o que Lousada e Dantas-Longhi (2014) chamam de voz da fala egocêntrica e voz da fala egocêntrica reconstituída, que foram identificadas por essas autoras em entrevistas de auconfrontação (AC) e de instrução ao sósia (IS $)^{40}$ em contexto de intervenção sobre o trabalho de jovens professores e formadores. Lousada e Dantas-Longhi (2014) levantam hipótese de que essas duas vozes "são indícios de uma tomada de consciência que se dá por meio da verbalização sobre o trabalho propiciada por essas entrevistas de confrontação" $(2014$, p.2).

As definições de fala egocêntrica e fala egocêntrica reconstituída são apoiadas nos estudos de Vygotski (1934/1997) que, ao retomar os experimentos de Piaget (1923/1968) sobre a fala egocêntrica em crianças, ou seja, sobre uma espécie de diálogo que a criança desenvolve consigo mesma, constata que a fala egocêntrica aumentava quando as crianças eram desafiadas, colocadas em conflito, diante da confrontação com uma atividade. Essa

\footnotetext{
${ }^{40}$ Seção 1.3 .
} 
descoberta faz Vygotski (1934/1997) indicar o discurso egocêntrico com um "instrumento de pensamento".

Nesse sentido, Lousada e Dantas-Longhi (2014) explicam que a formação da fala egocêntrica aparece na sobreposição de dois planos enunciativos distintos no momento das entrevistas de AC e IS. O primeiro plano é o da interação em curso, em que o entrevistador e o entrevistado estão engajados em uma troca comunicativa. $\mathrm{O}$ segundo plano corresponde ao segundo plano enunciativo, assim, o entrevistado se situa nesse outro plano, como se tivesse em situação de trabalho.

Além de constatarem nas entrevistas de AC e IS vozes da sala de aula, que consistem em pequenos diálogos entre professores e seus alunos, Lousada e DantasLonghi (2014) identificaram, também, vozes que ilustram um diálogo do sujeito consigo mesmo, chamadas de voz da fala egocêntrica reconstituída (na autoconfrontação) e voz da fala egocêntrica (na instrução ao sósia). De acordo com Lousada e Dantas-Longhi (2014, p.16):

\begin{abstract}
A voz da fala egocêntrica reconstituída consiste na recriação, sob a forma de uma voz do segundo plano enunciativo, do diálogo interior que o sujeito estabelece consigo mesmo em situação de conflito. Ela se assemelha à fala egocêntrica tal como interpretada por Vygotski ([1934]1997), porque representa o momento em que o indivíduo se encontra em situação de conflito ou de esforço intelectual, servindo de apoio para que se possa resolver um problema ou tomar uma decisão. Quanto a sua forma, ela possui características semelhantes às demais vozes pertencentes ao segundo plano enunciativo.
\end{abstract}

Para exemplificar essas vozes, expomos um excerto dos exemplos propostos pelas autoras (LOUSADA e DANTAS-LONGHI, 2014, p.16, grifos das autoras):

1306P. você acha que eu tava incomodando:: o fato de eu estar filmando assim?

(...)

1316D. pode ser que/pode ser que:: esteja incomodando um pouquinho... mas incomoda é óbvio que incomoda no meu caso, assim tipo, as duas/as duas que estavam ali atrás bem na câmera assim eu falei “putz eu preciso ir lá porque aqui/ali vai dar pra ouvir se elas estão falando certo ou errado” ((risos))

A fala egocêntrica reconstituída aparece introduzida por D. (professor entrevistado) pelo verbo discendi “falei”. Segundo as autoras, o professor D., ao perceber que suas alunas com mais dificuldades faziam as atividades próximas da câmera, pensou 
em verificar se elas estariam fazendo as atividades corretamente. Nesse exemplo, "eu falei" indica um falar consigo mesmo, verbalizado na AC em razão da presença da pesquisadora, mas não necessariamente verbalizado no momento da ação. O método permite que o professor reconstitua, além de suas ações, seu pensamento e o diálogo consigo mesmo na situação de trabalho.

Apesar das semelhanças entre a fala egocêntrica de Vygotski e a fala egocêntrica reconstituída, as autoras pontuam algumas diferenças (LOUSADA e DANTASLONGHI, 2014, p.17 e 18):

Em relação a sua forma, a voz da fala egocêntrica reconstituída não corresponde exatamente à fala egocêntrica vygotskiana. Ela não é lacunária, pois sua função comunicativa não pode ser abandonada, uma vez que ela é dirigida ao mesmo tempo: i) para si mesmo, pois é uma maneira de relembrar a experiência vivida, procurando compreender como as decisões sobre a aula foram tomadas; ii) para um destinatário exterior (a pesquisadora, o outro professor presente na entrevista), pois o enunciador não perde de vista a situação de AC, em que precisa explicar os motivos de sua ação a quem está compartilhando as imagens do vídeo [...]

Em relação a sua função, a voz da fala egocêntrica reconstituída também não corresponde exatamente à fala egocêntrica vigotskiana, pois é posterior e não simultânea ao conflito vivido. Essa voz não surge no diálogo da autoconfrontação para auxiliar as tomadas de decisão dos trabalhadores, mas para ajudar a reviver o momento vivido, propiciando a recriação do objeto em outra situação, como uma maneira de adquirir novas possibilidades de ação em relação a essa situação. Não se trata, assim, de uma verbalização espontânea motivada pelo conflito, mas de uma representação, no presente da enunciação, do diálogo interior do sujeito nas situações em que arbitragens foram necessárias, por isso a consideramos "reconstituída".

\subsubsection{As figuras de ação}

Com base nos estudos do interacionismo sociodiscursivo (BRONCKART, 1999/2009, 2006, 2008) e da Clínica da Atividade (CLOT, 1999, 2001), Bulea e Fristalon (2004) propõem a noção de Figuras de Ação (BULEA, 2010; BULEA e BRONCKART, 2010). Essa noção complementa a análise de entrevistas produzidas por trabalhadores, no sentido de colaborar com a observação do posicionamento de profissionais diante da 
tarefa a ser realizada, podendo servir de base para compreensão das representações desses profissionais sobre o seu trabalho.

A partir de análises de textos de entrevistas com enfermeiras, Bulea e Fristalon (2004) identificam cinco figuras de ação, a saber: ação ocorrência, ação acontecimento passado, ação experiência, ação canônica e ação definição. Em conformidade com Bulea (2010), explicaremos cada uma dessas figuras a seguir.

A figura de ação ocorrência é caracterizada por um forte grau de contextualização, pois o agir-referente está ligado à sua textualização. A construção dessa figura mobiliza elementos acessíveis no entorno do actante: "tal enfermeira, administrando cuidado a tal paciente, em tais condições" (BULEA, 2010, p.124). Do ponto de vista de sua organização enunciativa, a figura de ação ocorrência aparece principalmente nos segmentos do discurso interativo, sua referência temporal é a da situação de interação e o actante, representado por pronomes pessoais de primeira pessoa (eu), está implicado, assim como no exemplo proposto por Bulea (2010, p.124):

N: então eu vou fazer / então ela teve uma : : colecistectomia mas era uma intervenção delicada / então é por isso que ela tem dores hum importantes em pós-op / ela tem uma transver- sim uma transversa subcostal [...]

A figura de ação acontecimento passado apresenta-se como uma retomada "retrospectiva do agir". Essa figura caracteriza o agir com valor ilustrativo, trata-se de uma espécie de história de um evento para ilustrar o que se fala na situação de interação. A respeito de sua organização discursiva, essa figura de ação aparece em segmentos do relato interativo, seu eixo temporal é anterior ao da situação da entrevista, assim o conteúdo temático mobilizado está distanciado da situação de interação. Além disso, a figura é marcada por expressões temporais como por exemplo: "a última vez", "outro dia" (2010, p.133). Para melhor entendimento, expomos um exemplo dessa figura de ação com alguns destaques apresentados por Bulea (2010, p.132):

N: (...) a última vez por exemplo tu vês eu devia retirar fios em um paciente / e : : // ele tinha / um acúmulo de / de líquido seroso no nível da cicatriz eu tenho a cicatriz que se abriu // na extremidade da cicatriz / tinha uma mediana / era a ponta da cicatriz que se abriu [...] 
A figura de ação experiência é constituída por uma "compreensão da atividade sob o ângulo de cristalização pessoal de várias ocorrências das atividades vivenciadas" (BRONCKART e BULEA, 2010, p.55, tradução nossa). Essa figura de ação propõe, segundo Bulea (2010), um balanço do estado da experiência atual do actante em relação à tarefa relacionada, esse balanço é baseado em uma síntese da repetição da prática da tarefa em diferentes situações. A organização enunciativa dessa figura é sob a forma do discurso interativo, marcada pela presença de advérbios generalizantes, como: "sempre", "normalmente" etc. ou por sintagmas preposicionais e nominais: "de qualquer jeito", "todo o tempo" e de organizadores temporais: "depois", "após" etc. A seguir, apresentamos um exemplo dessa figura de ação em que a autora destaca um advérbio generalizante (BULEA, 2010, p.137-138):

J: quando tu abres teu curativo tu olhas a ferida / para ver bem hum efetivamente como ela está hum // sim para ver como ela está o que vais fazer com / mas depois hum / quando tu começas a limpar a / tu tentas ver teu / tu tentas olhar // um pouquinho o paciente para ver se tu lhe fazes mal para ver um pouquinho as reações que ele / que ele pode ter (...) eu creio que / enfim / eu sei (...) eu sempre tenho o olhar mais ou menos em direção à cara () para ver a cara do paciente para ver se / se tudo está bem se ele aceita se ele não aceita se ele acha isso FEIO se // ver um hum /() ver a reação hum.

A figura de ação canônica identifica o agir sob a forma de construção teórica. Essa figura expõe a tarefa a-contextualizada determinada por uma instância normativa exterior ao actante. A organização da figura de ação canônica se organiza no eixo do expor, sendo assim, apresenta-se como discurso teórico ou um misto de discurso teóricointerativo. Seu eixo temporal não é marcado ou delimitado, o actante é indicado por formas impessoais, como por exemplo: "a gente" ou o tu/você com valor genérico, assim como no exemplo de Bulea (2010, p.142):

A: (...) a gente entra em contato com os pacientes pois a gente tenta sempre segurá-los ao levantar quando eles ainda não se levantaram () então bom dia a gente aperta a mão / a gente pergunta como passou a noite o que deseja para o dia o que deseja para o asseio.

A figura de ação definição verifica o agir-referente como objeto de reflexão, tratase de uma tentativa de (re)definição do agir por parte do actante. Assim como a ação canônica, também é uma figura descontextualizada. O que difere essa figura de todas as 
outras é o fato de não possuir marcas de agentividade e não tematizar os gestos ou atos (BULEA, 2010, p.145). Como exemplo dessa figura de ação, apresentamos um excerto com alguns elementos destacados por Bulea (2010, p.145):

S: (...) pior é sempre um momento quando hum xxx permite discutir um pouquinho justamente / com o paciente // o o curativo é um cuidado que permite hum / que sempre é um cuidado que permite entrar em contato com o paciente eu acho / um momento um pouco mais sim (...) é um cuidado que é pouco mais longo // que que outros cuidados [EB: hum hum] que (...) eu digo o curativo porque o curativo é um ato que é um pouco mais longo ou um branco

Após o estudo do modelo de arquitetura textual do ISD, de Bronckart (1999/2009, 2006, 2008), juntamente com os conceitos de outros teóricos para complementar esse quadro teórico-metodológico, é importante dizer que o folhado textual tem recebido mudanças e complementações (BRONCKART, 2013). Essas alterações devem ser encaradas como naturais, já que para Bronckart (2013), a estruturação interna desse modelo textual é propensa para ser complementada e ajustada. Assim, abaixo, apresentamos um quadro com as alterações realizadas pelos recentes estudos de Bronckart (2013), que não foram plenamente consideradas para esta pesquisa pelo fato de não contarmos com publicações que esclareçam todos os pontos alterados.

\begin{tabular}{|c|c|c|}
\hline $\begin{array}{c}\text { Infraestrutura } \\
\text { Organização } \\
\text { temática } \\
\text { Temática } \\
\text { Agonística } \\
\text { Planificação } \\
\text { Organização } \\
\text { Discursiva } \\
\text { Tipos de } \\
\text { Discurso } \\
\text { Modos de } \\
\text { Articulação }\end{array}$ & $\begin{array}{c}\text { Mecanismos de } \\
\text { Textualização } \\
\text { Figura 3: O modelo de arquitetura textual reajustado de acordo com recentes mudanças no ISD }\end{array}$ \\
\hline
\end{tabular}

${ }^{41}$ Figura adaptada de Bronckart (2013), tradução nossa. 


\section{CAPÍTULO ॥ - METODOLOGIA DE PESQUISA}

Neste capítulo, apresentaremos os procedimentos metodológicos que foram utilizados para realizar este trabalho. Primeiramente, tratamos do contexto em que ocorreu a pesquisa - os cursos Extracurriculares de francês - assim como dos participantes deste estudo: Mariana, Flávia e a professora-pesquisadora. Em seguida, explicamos as etapas de coleta e geração de dados, para, posteriormente, descrevermos como foi feita a seleção desses dados coletados. Com isso, mostramos que optamos por uma situação de geração única de dados a partir de dois contextos diferentes para duas pesquisas de mestrado (a presente pesquisa e a de Mariana); para este estudo, o foco das análises foi nos dados de apenas um dos contextos: o de Mariana, professora iniciante de FLE, participante da pesquisa. Por fim, abordamos os procedimentos utilizados para a análise dos dados.

\section{1. $O$ contexto}

Nesta seção, mostramos o contexto onde desenrolou a pesquisa, para isso apresentamos o local de produção dos dados e os participantes envolvidos.

\subsection{Os cursos Extracurriculares de francês}

Nossa pesquisa investiga o trabalho do professor iniciante de FLE no contexto de trabalho da professora Mariana, participante desta pesquisa, ou seja, os cursos Extracurriculares de francês, oferecidos pelo Serviço de Cultura e Extensão Universitária $^{42}$ da Faculdade de Filosofia, Letras e Ciências Humanas (FFLCH) da Universidade de São Paulo (USP). Para definir esse contexto, apoiamo-nos nos trabalhos desenvolvidos pelos participantes do grupo de pesquisa ALTER-AGE-CNPq, como, por exemplo, Guimaraes-Santos, 2012; Dantas-Longhi, 2013; Melão, 2014; Añez-Oliveira, 2014; Rocha, 2014; Silva, 2015; Menezes, 2015, que também têm pesquisas realizadas nesse contexto.

${ }^{42}$ Para maiores informações: 〈http://sce.fflch.usp.br/> (consultado 20/01/2016). 
Os cursos Extracurriculares de francês oferecem aulas de francês à comunidade interna e externa da USP. Com o objetivo de desenvolver habilidades orais e escritas dos alunos em língua francesa em situações do cotidiano, os cursos são destinados aos alunos graduandos e pós-graduandos, professores da rede pública e particular, funcionários da universidade, estudantes e demais interessados na língua estrangeira. O único prérequisito exigido é ter o ensino médio completo, sendo assim, o perfil dos alunos dos cursos é bem heterogêneo, o que significa que em uma mesma sala é possível encontrar pessoas com diferentes idades, formação educacional, interesses etc. Os cursos são gratuitos para docentes e funcionários da FFLCH e para os beneficiados com bolsas de estudo, sorteadas na matrícula para a comunidade USP e pessoas da terceira idade. Além disso, são oferecidos descontos para graduandos e pós-graduandos da FFLCH, professores ativos da Rede Pública, pessoas com idade superior a 60 anos e monitores bolsistas e estagiários da FFLCH.

A carga horária total de cada curso oferecido pelos cursos Extracurriculares de francês, por semestre, é de 45 horas distribuídas em 15 aulas para os que fazem uma vez por semana e 30 aulas para os que fazem duas vezes por semana. Para as turmas de 30 aulas, os cursos são oferecidos no horário do almoço de segundas e quartas ou terças e quintas com duração de 1 hora e 30 minutos cada aula. Já as turmas de 15 aulas têm uma vez por semana uma aula de 3 horas no período da tarde (de segunda a sexta-feira e ao sábado de manhã). Esses horários são determinados desse modo, pois os cursos são oferecidos nas salas do prédio de Letras, que durante os períodos matutino e noturno são ocupadas pelos alunos de graduação em Letras.

Durante as férias de início e meio de ano, os cursos Extracurriculares de francês oferecem cursos intensivos, ministrados geralmente de segunda à quinta-feira com a duração de 3 horas cada aula.

Os livros utilizados pelos cursos de francês são o "Alter Ego +" 1, 2 e 3, da editora Hachette e o "Le Nouvel Edito" B2, da editora Didier. As turmas são distribuídas em 14 níveis, sendo organizadas da seguinte maneira ${ }^{43}$ :

\footnotetext{
${ }^{43}$ Retirado do site: <http://sce.fflch.usp.br/node/1759> (consultado em 05/09/2014).
} 


\begin{tabular}{|l|c|}
\hline \multicolumn{1}{|c|}{ Níveis } & Livros \\
\cline { 1 - 1 } Nível 1 & \multirow{2}{*|}{ Alter Ego + 1 } \\
\hline Nível 2 & \\
\hline Nível 3 & Alter Ego + 2 \\
\hline Nível 4 & \\
\hline Nível 5 & Alter Ego + 3 \\
\hline Nível 6 & \\
\hline Nível 7 & Le Nouvel Edito B2 \\
\hline Nível 8 & Le Nouvel Edito B2 \\
\hline Nível 9 & Le Nouvel Edito B2 \\
\hline Nível 10 & Le Nouvel Edito B2 \\
\hline Nível 11 & \\
\hline Nível 12 & \\
\hline Nível 13 & ---- \\
\hline \begin{tabular}{l|l|} 
Aspectos da \\
cultura \\
francófona
\end{tabular} & \\
\hline
\end{tabular}

Quadro 7: Tabela de níveis das turmas dos cursos Extracurriculares

Os cursos de francês são organizados em semestres, cada nível corresponde a um semestre de curso. O pré-requisito para cursar níveis acima do nível 1 é ter sido aprovado no nível anterior. Caso contrário, os alunos só podem cursar um nível acima do nível 1 se forem aprovados no teste de nível, realizado com um professor-monitor dos cursos.

Os professores que dão as aulas nos cursos Extracurriculares de francês têm estatuto de monitores para a universidade, pois são, na verdade, alunos de graduação ou pós-graduação que recebem uma bolsa-monitoria, assim como outros alunos que desempenham alguma atividade na USP com carga horária reduzida. Assim, eles não possuem vínculo empregatício com a instituição e suas atividades são remuneradas por uma bolsa que corresponde às horas-aula. Por essas razões, os professores dos cursos Extracurriculares são considerados como professores-monitores.

O trabalho do professor-monitor de francês inclui, além das aulas de francês, como é o caso em outras instituições, a preparação do material pedagógico complementar e as correções das avaliações. Além disso, quando há atividades complementares, como a elaboração de novas avaliações e dos testes de nível dos alunos, elas são remuneradas

${ }^{44}$ Não há um livro utilizado para este nível. 
separadamente. Para ser um professor-monitor dos cursos Extracurriculares de francês é preciso ser aprovado no processo de seleção que compreende: exame de curriculum vitae, realização de prova escrita e entrevista com três docentes da área de Estudos Linguísticos, Literários e Tradutológicos em francês. Pode se inscrever para o processo seletivo o candidato que possui diploma de graduação e vínculo com a USP (graduação ou pósgraduação). Assim, o grupo de professores-monitores pode ser formado por bacharéis cursando a licenciatura ou um segundo curso de graduação e alunos de mestrado ou doutorado.

Como expomos na introdução, se considerarmos o professor iniciante como aquele que tem menos de quatro anos de carreira, como define Huberman (1992), podemos dizer que o perfil de grande parte dos professores-monitores é de iniciante na profissão docente, pois muitos desempenham essa carreira pela primeira vez ou estão em seus primeiros anos de atividade. De acordo com Dantas-Longhi (2013), no ano de 2012, os professores-monitores dos cursos Extracurriculares com pouca ou nenhuma experiência totalizavam 35\%, já aqueles com um ou dois anos de experiência eram representados por $18 \%$, os professores-monitores com dois a quatro anos de experiência eram $35 \%$ e aqueles com mais de quatro anos de experiência eram $12 \%$.

Além do compromisso com o ensino dos alunos, os cursos Extracurriculares de francês visam também à formação contínua de professores-monitores. Sabendo disso, alguns professores recém-formados procuram trabalhar nesse contexto, para continuar os estudos sobre ensino-aprendizagem, com a oportunidade de refletir sobre teoria e prática. Além disso, aqueles que são alunos de iniciação científica, mestrado e doutorado podem aplicar as pesquisas desenvolvidas em seus projetos nesses cursos.

Guimarães-Santos (2012) aponta que há encontros mensais (reuniões pedagógicas) dirigidos pela coordenadora dos cursos, que é professora da USP do programa de Estudos Linguísticos, Literários e Tradutológicos em Francês. Nessas reuniões, ocorrem discussões sobre o andamento das aulas, leituras e debates de textos, apresentações de atividades elaboradas pelos professores-monitores, entre outras atividades. Os encontros são remunerados por uma bolsa, da mesma forma que as aulas. Ao final de cada semestre, a coordenadora solicita aos professores-monitores um relatório de atividades realizadas, redigido em francês. 
A professora participante desta pesquisa, Mariana, professora iniciante em FLE e aluna de mestrado e de licenciatura em Letras da Universidade de São Paulo atua como monitora dos cursos extracurriculares de francês.

\subsection{Os participantes}

Como já apontamos na introdução, esta pesquisa teve início em 2013 com a formação de um coletivo de trabalho constituído no grupo de pesquisa ALTERAGE/CNPq da USP. Três integrantes desse grupo de pesquisa participaram da geração de dados: i) Mariana, monitora professora dos cursos extracurriculares de francês; ii) Flávia, professora que conduziu as Instruções ao Sósia e seus retornos e iii) Fernanda, a professora pesquisadora ${ }^{45}$.

\section{i) Mariana, monitora professora dos cursos extracurriculares de francês}

No desenvolvimento da pesquisa, Mariana era professora-monitora dos cursos extracurriculares de francês desde julho de 2013, mesmo período em que ingressou no curso de mestrado da FFLCH da área de Estudos Linguísticos, Literários e Tradutológicos em Francês. Bacharela em Letras, com habilitação em português e francês, pela FFLCH da USP. Além disso, cursava licenciatura em Letras, também com habilitação em português e francês, na Faculdade de Educação (FE) da USP.

Antes de seu ingresso no mestrado, Mariana desenvolveu três projetos de iniciação científica sob orientação da mesma professora que orienta sua pesquisa de mestrado, esses projetos são intitulados: "Aprender a língua francesa na universidade: uma proposta a partir de gêneros textuais" (2009 - 2010); "O ensino do francês na universidade: organização do currículo baseado em gêneros textuais" (2010 - 2011) e "Aprendizagem da produção de gêneros textuais da esfera acadêmica na universidade: resumo e resenha" (2011 - 2012). Percebemos que seus três projetos de iniciação científica centraram-se no estudo sobre os gêneros textuais, no entanto, para a sua pesquisa de mestrado, Mariana direcionou sua investigação em torno de outro viés: o trabalho do professor iniciante. Isso porque, como explicamos na introdução, Mariana estava interessada em compreender questões relacionadas ao ensino do FLE. Assim, sua pesquisa de mestrado tem como título "O trabalho do professor iniciante de FLE: prescrições, desafios e formação".

\footnotetext{
45 Mesmo sem um comitê de ética em nossa faculdade, Flávia e Mariana assinaram um termo de consentimento livre e esclarecido sobre a participação no presente estudo.
} 
As primeiras experiências de Mariana como docente começaram em agosto de 2010 na escola de idiomas Wizard, onde permaneceu até o final de novembro do mesmo ano. Em janeiro de 2011 iniciou suas atividades na Skill e encerrou-as em fevereiro de 2012. Em março de 2012, começou a lecionar no CAVC idiomas, onde trabalhava durante o desenvolvimento da pesquisa ${ }^{46}$.

Mariana também atuou com o ensino de português como língua estrangeira no ano escolar de 2012/2013, quando trabalhou como professora-assistente para o Ministério da Educação Nacional da França na cidade Bordeaux.

\section{ii) Flávia, professora que conduziu as Instruções ao Sósia e seus retornos}

Flávia tem experiência como professora de FLE desde 1996, no processo de geração dos dados, trabalhava no Centro de Línguas da Secretaria de Educação do Estado do Paraná e era aluna de doutorado do programa de Estudos Linguísticos, Literários e Tradutológicos em Francês da FFLCH da USP.

Com pesquisa também ligada ao trabalho do professor de FLE, Flávia utilizou, em sua tese de doutorado, um dos métodos indiretos desenvolvidos pela ergonomia da atividade e pela clínica da atividade: a autoconfrontação, procedimento já explicado na fundamentação teórica. Mais recentemente, pôde aprofundar o estudo sobre os métodos indiretos, visto que esteve na Université Aix-Marseille, no laboratório $\mathrm{ADEF}^{47}$ com a equipe ERGAPE, sob co-orientação do professor Frédéric Saujat. Por estar inserida nesse contexto, foi convidada para dirigir as duas instruções ao sósia e seus retornos, assumindo o papel de sósia.

O contexto de pesquisa de doutorado de Flávia é o do CELEM - Centro de Línguas Estrangeiras Modernas do estado do Paraná, onde um grupo de professores participou de um projeto de elaboração de um livro didático público para o ensino da língua francesa. O objetivo de sua pesquisa é estudar a relação do professor com sua atividade profissional diante das orientações/prescrições para seu trabalho, a percepção que eles têm de seu agir profissional e o papel que o ensino com gêneros textuais pode desempenhar na atividade de trabalho docente. Para tanto, ela analisa textos produzidos

\footnotetext{
46 Vale ressaltar que antes de 2013, Mariana não possuía graduação em bacharelado em Letras Português/Francês. Portanto, consideramos que suas experiências profissionais anteriores a essa data são de aluna de graduação. Não temos como intenção desconsiderar essas experiências. Contudo, essa informação é relevante, pois é uma evidência de que Mariana é professora (graduada) iniciante em FLE. 47 Para mais informações: http://adef.univ-amu.fr/fr (consultado em 26/01/2016).
} 
sobre o processo de elaboração por vários protagonistas (instituição, professores formadores, professores elaboradores) e textos produzidos pelos professores durante o trabalho em sala de aula.

\section{iii) A professora pesquisadora}

Formei-me no curso de Letras português-francês pela Universidade Estadual Paulista Júlio de Mesquita Filho (UNESP) em 2009. A partir de 2010, comecei a lecionar francês e português em escolas estaduais e particulares.

Minha trajetória como professora de FLE iniciou-se na escola de idiomas Wizard, onde trabalhei alguns meses. Em seguida, de 2011 a 2012, lecionei na escola de idiomas Skill e, ao mesmo tempo, em um centro de línguas de uma escola particular. No primeiro semestre de 2012, trabalhei no projeto desenvolvido pela Secretaria da Educação do Estado de São Paulo, o Centro de Estudo de Línguas (CEL) ${ }^{48}$. Não foi possível prosseguir o trabalho nesse projeto, pois no mesmo ano mudei-me de cidade, assim comecei a trabalhar em uma escola privada de ensino de FLE, onde trabalhei até 2014. Com exceção dessa última escola, em todas as outras eu era a única professora de FLE. Além de não ter com quem compartilhar as questões sobre o trabalho, havia poucas orientações sobre o que fazer no contexto de trabalho e, portanto, as questões relativas ao ensino do FLE estavam sempre presentes em meu cotidiano. Em duas dessas escolas, não havia sequer materiais didáticos para o professor e os alunos. Diante desses problemas, inscrevi-me na disciplina de Metodologia de Pesquisa em Didática e Ensino-Aprendizagem de Línguas Estrangeiras, como destaquei no capítulo de introdução.

O contato com a disciplina de metodologia e com os estudos sobre o trabalho chamou-me atenção para esse campo de estudos. Concomitantemente, meu interesse pelo ensino de francês foi aumentando, pois percebia uma maior motivação dos alunos pela aprendizagem da língua francesa do que pela língua portuguesa. Essa motivação tornava meu trabalho mais prazeroso e fortalecia minha intenção, já existente desde a graduação, de continuar os estudos na área de ensino de língua estrangeira.

Por essa razão, em 2013, ingressei no curso de mestrado do programa de Estudos Linguísticos, Literários e Tradutológicos em Francês da FFLCH da USP com a intenção

\footnotetext{
${ }^{48}$ Para mais informações: http://www.educacao.sp.gov.br/portal/projetos/centros-de-estudos-de-linguas (consultado em 05/09/2014).
} 
de estudar sobre o professor de FLE com pouca experiência, para refletir sobre o trabalho desse professor ao mesmo tempo em que aprendia meu próprio trabalho.

\section{Etapas de coleta e geração de dados}

Nesta seção, descrevemos como foram realizadas a coleta e geração de dados, indicando suas etapas e os procedimentos utilizados.

A coleta e geração de dados obedeceram quatro etapas apresentadas a seguir: i) coleta do documento prescritivo no contexto dos cursos Extracurriculares de francês; ii) produção de diários de aulas escritos pela participante; iii) realização de duas instruções ao sósia (IS), gravadas em áudio, com a participação das três integrantes do grupo de pesquisa ALTER-AGE e iv) retornos às instruções ao sósia (discussão dos comentários produzidos a partir das transcrições das IS, também gravada em áudio).

A coleta e a geração de dados iniciaram-se no segundo semestre de 2013. Nessa época, reunimos os documentos que orientam o trabalho da professora-monitora nos cursos Extracurriculares de francês, além disso, solicitamos a Mariana a produção de diários de aulas e realizamos duas entrevistas de instrução ao sósia e um retorno a uma das entrevistas. No primeiro semestre de 2014, coletamos os diários de aulas e realizamos o último retorno à instrução ao sósia. O quadro abaixo mostra as etapas e as datas da coleta e da geração de dados:

\begin{tabular}{|c|l|l|l|}
\hline \multirow{4}{*}{ Coleta de dados } & \multicolumn{1}{|c|}{ Data } & \multicolumn{1}{c|}{ Dados } & \multicolumn{1}{c|}{ O que são } \\
\hline & $\begin{array}{l}\text { Segundo semestre de } \\
2013\end{array}$ & Guide du Moniteur & $\begin{array}{l}\text { Documento prescritivo do } \\
\text { contexto da professora iniciante } \\
\text { dos cursos Extracurriculares de } \\
\text { francês }\end{array}$ \\
\hline \multirow{5}{*}{$\begin{array}{c}\text { Geração de } \\
\text { dados }\end{array}$} & $\begin{array}{l}\text { Segundo semestre de } \\
2013 \text { (solicitação); } \\
\text { Primeiro semestre de } \\
2014 \text { (coleta) }\end{array}$ & Diários de aulas & $\begin{array}{l}\text { Textos escritos pela professora } \\
\text { iniciante após suas aulas, } \\
\text { registrando suas reflexões sobre } \\
\text { elas }\end{array}$ \\
\cline { 2 - 4 } & novembro de 2013 & Instruções ao Sósia & $\begin{array}{l}\text { Entrevistas realizadas com a } \\
\text { professora iniciante }\end{array}$ \\
\cline { 2 - 4 } & $\begin{array}{l}\text { Novembro de 2013 e } \\
\text { abril de 2014 }\end{array}$ & $\begin{array}{l}\text { Retornos às } \\
\text { Instruções ao Sósia }\end{array}$ & $\begin{array}{l}\text { Discussões dos comentários } \\
\text { produzidos a partir das entrevistas }\end{array}$ \\
\hline
\end{tabular}

Quadro 8: Data de coleta e geração de dados 


\subsection{O "Guide du Moniteur"49 dos cursos Extracurriculares de francês}

Consideramos os conceitos trabalhados na fundamentação teórica sobre o trabalho prescrito (CLOT e YVON, 2004; BERTHET e CRU, 2003; BAZET, 2002; DAGUZON e GOIGOUX, 2007; BARRICELLI, 2012), para analisamos um dos documentos prescritivos ${ }^{50}$ do trabalho da professora participante: o Guide du Moniteur, presente na instituição de ensino selecionada - os cursos Extracurriculares de francês.

O Guide du Moniteur é um documento prescritivo que foi pensado para auxiliar o trabalho dos professores-monitores, pois antes de sua existência, as informações contidas nele eram passadas oralmente em reuniões de ingresso de novos monitores-professores (MENEZES, 2015). Sendo assim, desde de sua produção, esse documento é entregue a todos esses monitores ingressantes. Escolhemos analisar o Guide du Moniteur ${ }^{51}$, pois ele se destina, principalmente, aos professores-monitores recém-chegados aos cursos Extracurriculares de francês, ou seja, aos professores iniciantes, nosso alvo de estudo.

\subsection{Os diários de aulas}

Os diários de aula são textos escritos pela professora participante da pesquisa, a nosso pedido. Neles são relatadas as experiências vivenciadas pela professora no ensino de FLE. No início do primeiro semestre de 2013, pedimos a Mariana para começar com as produções dos diários após suas aulas, explicando que a proposta não era de produzir mecanicamente a cada aula um diário, mas escrever a partir de aulas ou momentos mais significativos, que a fizessem refletir sobre seu trabalho.

Mariana produziu quatro diários escritos em francês, digitados e enviados por email, no primeiro semestre de 2014, para a professora-pesquisadora. Os diários de aula foram produzidos nos seguintes dias:

\footnotetext{
${ }^{49} \mathrm{O}$ Guia do Monitor.

${ }^{50}$ Um documento que orienta o trabalho do professor de FLE é o Cadre Européen Commun de Références (CECR). Nesta pesquisa não o analisamos por se tratar de documento bem abrangente no que se refere aos destinatários, já que é referência para todos os interessados em ensino de línguas estrangeiras em vários países. Além disso, ele não se define como documento prescritivo, mas como uma referência para o ensino; por isso, o CECR traz "recomendações” para o ensino-aprendizagem (Conseil de l'Europe, 2001: 5).

51 A coleta para a análise do Guide du Moniteur foi autorizada pela coordenadora dos cursos Extracurriculares de francês.
} 


\begin{tabular}{|c|c|}
\hline Diários & Data \\
\hline Diário I & $28 / 03 / 2014$ \\
\hline Diário II & $30 / 03 / 2014$ \\
\hline Diário III & $17 / 04 / 2014$ \\
\hline Diário IV & $24 / 04 / 2014$ \\
\hline
\end{tabular}

Quadro 9: Diários de aulas e as datas de suas produções

\subsection{Instruções ao sósia e retornos às instruções ao sósia}

As entrevistas de instruções ao sósia (IS) e os retornos às IS foram produzidos no segundo semestre de 2013 e primeiro semestre de 2014 e contaram com a participação da professora-pesquisadora (Fernanda), da professora-monitora dos cursos Extracurriculares (Mariana) e da professora que conduziu as IS e seus retornos, a sósia (Flávia).

Como já apontamos na seção sobre os participantes da pesquisa, Flávia, Mariana e eu éramos alunas de pós-graduação da mesma universidade e faculdade. No entanto, diferentemente de Mariana, Flávia e eu não moramos em São Paulo. Esse fato influenciou na escolha das datas de produções das entrevistas e seus retornos, pois tivemos que contar com a coincidência de estarmos, nós três, em São Paulo.

Todas as instruções ao sósia e os seus retornos desenvolveram-se na Universidade de São Paulo em dois prédios diferentes da FFLCH. A primeira IS e o seu retorno aconteceram em salas do prédio do curso de Letras, no mês de setembro e novembro de 2013, respectivamente. A segunda IS ocorreu no mês de novembro do ano de 2013, também em uma sala do prédio de Letras e o seu retorno só foi possível em abril de 2014, em uma sala do prédio de Filosofia.

No quadro abaixo, é possível ver as datas das produções das entrevistas e seus retornos e a duração total de cada etapa.

\begin{tabular}{|l|c|c|}
\hline \multicolumn{1}{|c|}{ Procedimento } & Data do procedimento & Duração total \\
\hline $\mathbf{1}^{\mathbf{a}}$ Instrução ao Sósia & $30 / 09 / 2013$ & $01: 24: 16$ \\
\hline Retorno à 1a Instrução ao Sósia & $11 / 11 / 2013$ & $00: 52: 51$ \\
\hline $\mathbf{2}^{\text {a }}$ Instrução ao Sósia & $27 / 11 / 2013$ & $01: 18: 52$ \\
\hline Retorno à $\mathbf{2}^{\mathbf{a}}$ Instrução ao Sósia & $24 / 04 / 2014$ & $00: 34: 59$ \\
\hline
\end{tabular}

Quadro 10: Datas e duração dos procedimentos instruções ao sósia 
Tanto as entrevistas de IS quanto seus retornos foram produzidos em língua francesa, por ser a língua que utilizamos em nossos trabalhos. Essa decisão foi tomada por mim e Mariana antes da gravação da primeira IS, quando Flávia perguntou se preferíamos dar as instruções a ela (sósia) em português ou francês.

\section{A constituição do coletivo e os procedimentos de seleção de dados}

Nesta seção, apresentaremos os procedimentos utilizados para a seleção de dados. Para tanto, baseamo-nos no modelo de pesquisa em contexto de trabalho proposto por Bronckart (2008), que orienta a organização dos conjuntos de dados. Desse modo, nossa pesquisa reflete alguns conjuntos de dados organizados conforme o quadro a seguir:

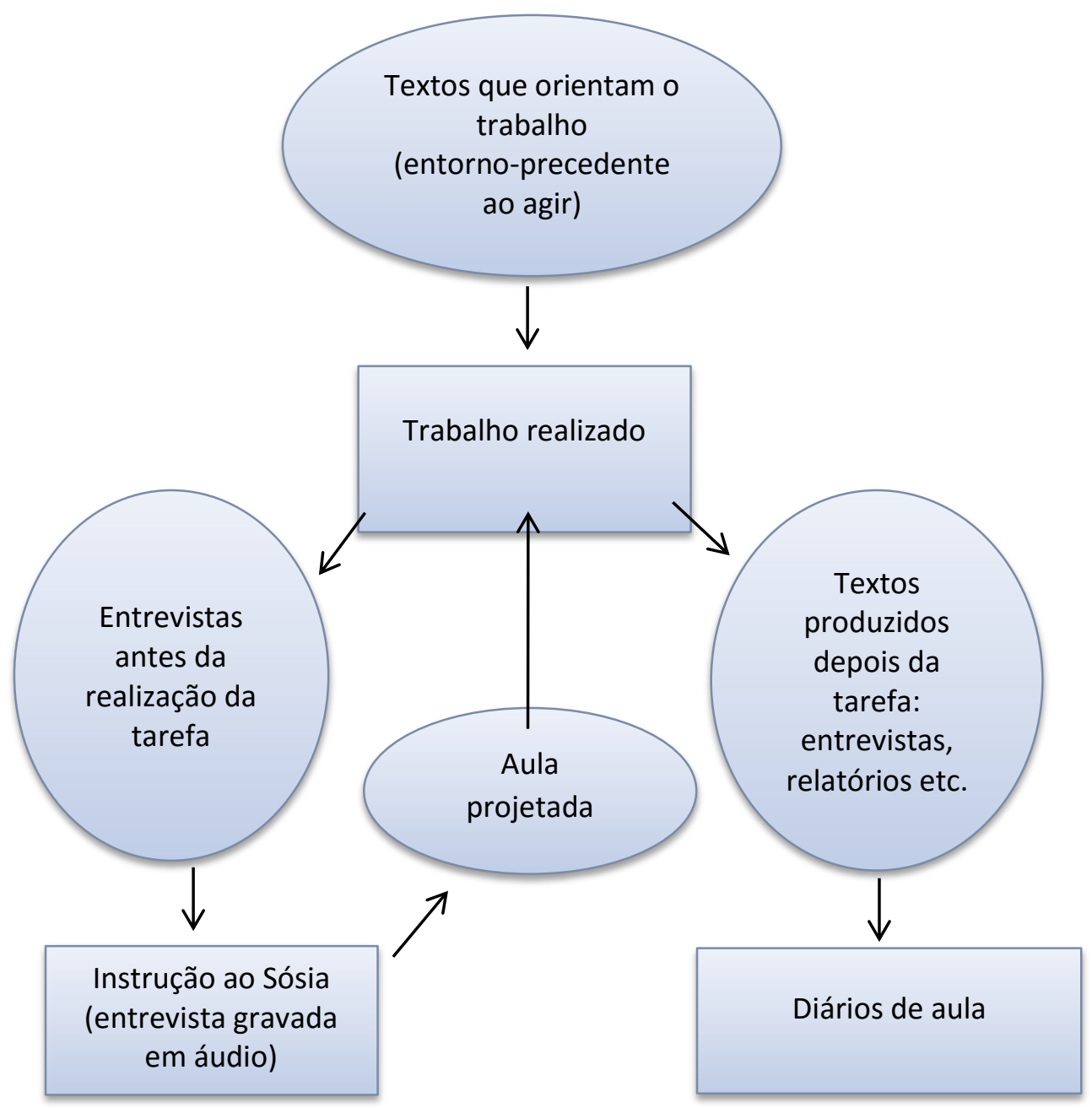

Figura 4: Conjunto central dos dados de nossa pesquisa, com base em Bronckart (2008, p.132) 
O esquema nos mostra que o conjunto central dos dados é constituído pelo trabalho realizado, ou seja, a aula dada. Nesta pesquisa, não há registros do trabalho realizado, o que há é um resgate pela memória desse trabalho que é projetado para o futuro (entrevistas de instrução ao sósia) e também uma reflexão sobre o trabalho realizado (diários de aula).

Outro conjunto de dados pertence ao que Bronckart (2008, p.132) chama inicialmente de "trabalho prescrito", passando a denominá-lo de "entorno-precedente do agir”. Esse conjunto é representado em nossa pesquisa pelo documento que orienta o trabalho da professora participante: o Guide du Moniteur.

O terceiro conjunto, de acordo com Bronckart (2008), é composto por textos produzidos pelo trabalhador antes e depois de sua tarefa. No caso dos textos produzidos depois da tarefa, coletamos os diários de aulas escritos pela professora. No que diz respeito aos textos produzidos antes da tarefa, podemos considerar o método indireto de instrução ao sósia, que é uma entrevista ocorrida antes da tarefa, em que o professorinstrutor projeta a aula que ainda será realizada.

Para a análise dos dados, fizemos um recorte para que fosse possível responder as questões desta pesquisa. Assim, quase todos os dados foram analisados em sua totalidade, com exceção das instruções ao sósia.

Como discutido nos pressupostos teóricos, a instrução ao sósia é um procedimento de entrevista gravada em áudio desenvolvida pela Clínica da Atividade e Ergonomia da Atividade (CLOT, 2001b; AMIGUES, 2004; SAUJAT, 2004, 2005), com base no método inicialmente proposto por Oddone (1981) em que os participantes assumem os papeis de instrutores e de sósia, sendo que o instrutor, imaginando que será substituído em seu trabalho, deve instruir o sósia para que ninguém perceba a mudança, enquanto que o sósia deve conseguir o máximo de informações possíveis sobre o contexto de trabalho e as atividades do instrutor.

Em nossa pesquisa, quem desempenhou o papel de sósia foi Flávia, pois já era uma pesquisadora mais experiente, doutoranda e conhecedora do método indireto de autoconfrontação, ao passo que Mariana e eu fomos as instrutoras de Flávia. Essa configuração da IS justifica-se pelo modo como nosso pequeno coletivo foi formado dentro de um grupo de pesquisa: duas professoras iniciantes de FLE (eu e Mariana), que querem aprender o seu próprio métier e estão iniciando a pesquisa de Mestrado, reúnem- 
se com uma professora mais experiente em FLE (Flávia) que já estuda para sua pesquisa de doutorado linhas das Ciências do Trabalho.

Desse modo, optamos por uma situação de geração única de dados a partir de dois contextos diferentes de trabalho para duas pesquisas de mestrado. Assim, Mariana é a participante desta pesquisa, juntamente com o contexto dos Cursos Extracurriculares, ao passo que eu sou a participante da pesquisa de Mariana, juntamente com o contexto de escola particular em que trabalhava. Para desenvolver as IS era preciso a presença de alguém para mediar as entrevistas, assim como as discussões desenvolvidas, já que tanto eu quanto Mariana nos posicionamos como instrutoras, portanto Flávia foi nossa sósia.

A escolha pelo método da IS, ao invés da autoconfrontação (método já utilizado por Flávia), pareceu-nos mais apropriada por dois motivos: primeiramente, porque nossas aulas não seriam filmadas, não trazendo tanta exposição para nós duas que estávamos iniciando a carreira docente, assim ficamos mais confortáveis com a opção de a entrevista de IS ser registrada somente em áudio e posteriormente transcrita. O segundo motivo diz respeito ao meu contexto de trabalho, que, por se tratar de uma escola particular, não estava habituada com a situação de pesquisa e, muito provavelmente, teria impedido a filmagem das aulas.

A opção pela situação de geração única de dados responde a várias indagações e suscita outras, que explicaremos a seguir:

- tanto Mariana quanto eu estávamos muito interessadas em compreender a aprendizagem do trabalho de professor de FLE, pois passávamos por esse processo. No entanto, ao nos basearmos no método da IS e na Clínica da Atividade e Ergonomia da Atividade, sabíamos que faríamos o que é chamado de intervenção: ou seja, trata-se de intervir em uma situação de trabalho externa a nossa, propiciando uma possível transformação da prática e, com isso, gerar dados que podem ser posteriormente analisados em pesquisa. Sendo assim, tínhamos claro que, ao adotar essa perspectiva teórico-metodológica, faríamos uma análise da situação de trabalho de outro professor, o que não impediria, por outro lado, que nossa situação de trabalho fosse analisada por outro membro do coletivo ou, até mesmo, do grupo de pesquisa.

- estávamos, ao mesmo tempo, iniciando a carreira docente e aprendendo a fazer pesquisa, com os métodos indiretos: portanto, pareceu-nos interessante aproveitar essa situação para, ao mesmo tempo, aprendermos a fazer pesquisa e nos formarmos pela análise do trabalho; 
- ao convivermos, percebemos as diferenças de nossos contextos de trabalho para a aprendizagem do trabalho educacional, portanto, pensamos que seria interessante, para nossa própria aprendizagem, se pudéssemos compará-los e contrastá-los;

- por outro lado, sabemos que essa escolha pode suscitar questionamentos, já que não estamos tão isentas e tão isoladas da situação de geração de dados que estamos analisando. No entanto, julgamos que isso não é um verdadeiro problema para a pesquisa, pois procuramos guardar inúmeras instâncias de discussão com pares externos à situação de trabalho e de distanciamento que nos possibilitaram analisar com propriedade os dados.

Sendo assim, recortamos nossos dados de modo a selecionar as partes em que Mariana era foco da intervenção. Dessa forma, a primeira etapa das IS está dividida em três partes: a primeira, pelas instruções de Mariana; a segunda, pelas minhas instruções e a terceira, por um breve debate das três participantes, que tomam a palavra livremente. Já a segunda etapa da IS - o retorno à IS - apresenta uma discussão, realizada após a transcrição da IS juntamente com comentários por escrito. Nessa etapa, todos os participantes têm liberdade para tomar a palavra quando quiserem. Com essas circunstâncias, centramos nossa análise nas produções de Mariana, por isso trabalhamos somente com uma parte das etapas da IS (parte em que Mariana é instrutora e o breve debate). Para a análise dos retornos, consideramos a gravação em sua íntegra, apesar disso, buscamos nos centrar nas questões ligadas ao trabalho de Mariana. No esquema abaixo, representamos a constituição do coletivo, os textos que fazem parte do contexto de trabalho de cada professora e os textos produzidos pelas professoras, assim como os textos de instruções ao sósia. No entanto, buscando dar maior clareza aos dados desta pesquisa, destacamos em cinza, os elementos que são fundamentais para as análises desta pesquisa: a professora iniciante de FLE Mariana, o documento que orienta seu trabalho o Guide du Moniteur, seus diários de aula e as instruções ao sósia e seus retornos centrados em Mariana e seu contexto de trabalho: 


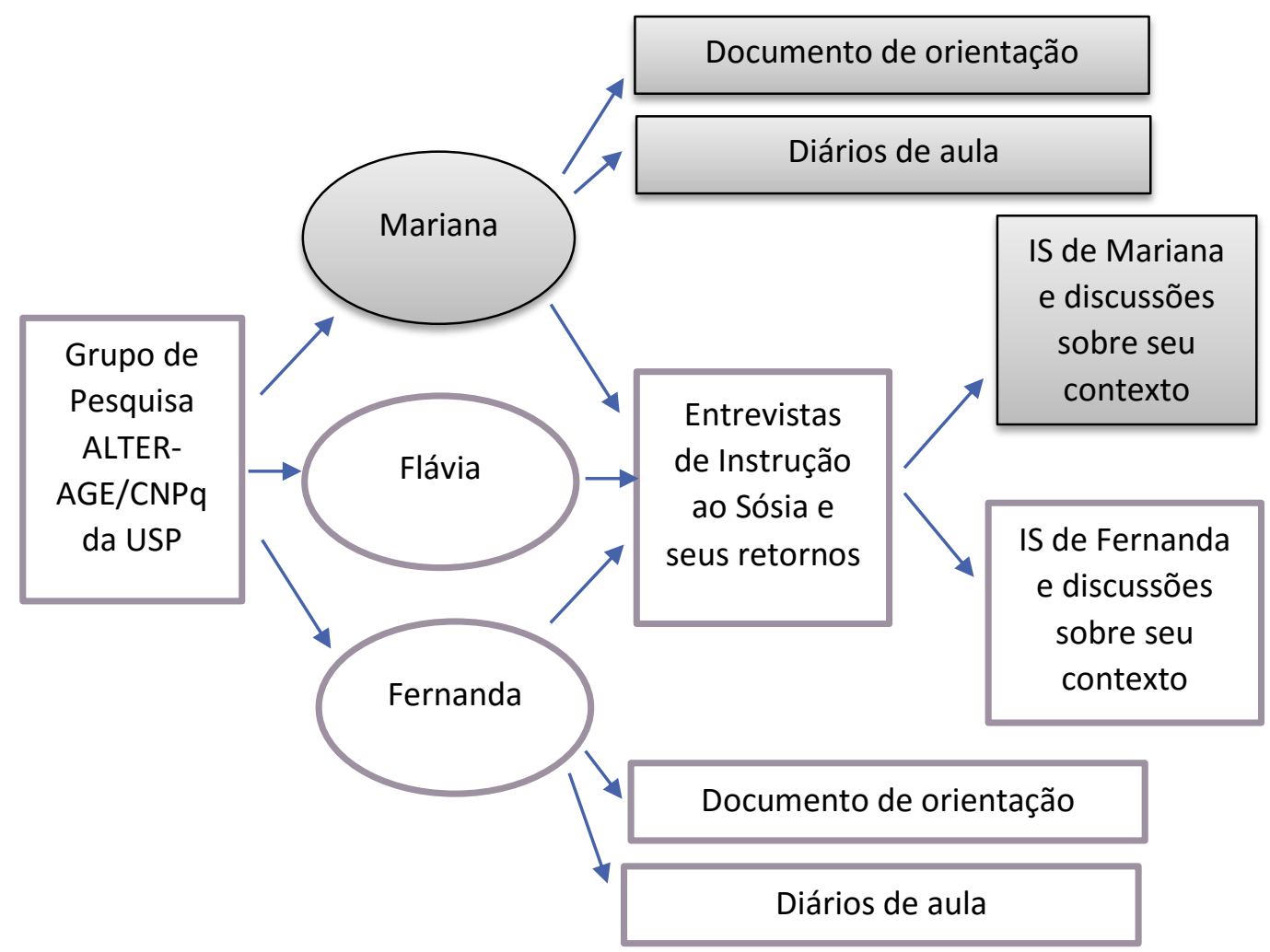

Figura 5: Formação do coletivo e os procedimentos de seleção de dados

Dessa forma, podemos dizer que, apesar das entrevistas de IS serem constituídas pelas instruções de duas professoras iniciantes em contextos diferentes, tivemos como intenção observar apenas os trechos produzidos por uma das professoras: Mariana.

Abaixo apresentamos uma síntese de todos os dados coletados ou gerados e os dados que foram analisados:

\begin{tabular}{|l|c|c|}
\hline \multicolumn{1}{|c|}{ Dados } & Totalidade dos Dados & Dados analisados \\
\hline Guide du Moniteur & 16 páginas & Todas as páginas \\
\hline Diários de aula & 4 diários (2 páginas) & Todos os diários \\
\hline Instruções ao Sósia & $\begin{array}{c}\text { Instruções de Mariana; } \\
\text { instruções da professora- } \\
\text { pesquisadora e breve } \\
\text { debate }\end{array}$ & $\begin{array}{c}\text { Instruções de Mariana e } \\
\text { breve debate }\end{array}$ \\
\hline $\begin{array}{l}\text { Retornos às Instruções ao } \\
\text { Sósia }\end{array}$ & $\begin{array}{c}\text { Discussão dos textos- } \\
\text { comentários produzidos } \\
\text { após a IS }\end{array}$ & $\begin{array}{c}\text { Discussão completa, } \\
\text { análise centrada em } \\
\text { Mariana }\end{array}$ \\
\hline
\end{tabular}

Quadro 11: Síntese dos dados coletados ou gerados e dos dados analisados 


\section{Forma de análise dos dados}

Analisamos os textos coletados de acordo com o modelo de análise textual do interacionismo sociodiscursivo (ISD), proposto por Bronckart (1999) e apresentado nos pressupostos teóricos. Fizemos uma seleção das categorias desse modelo que poderiam ser úteis para nossa análise, assim como acrescentamos a categoria das figuras de ação, propostas por Bulea (2010). Além disso, incluímos categorias de análise próprias da Análise da Conversação, como sugere o próprio Bronckart (2010). Para tanto, utilizamos os trabalhos de Marcuschi (2001). As categorias efetivamente utilizadas são detalhadas abaixo.

Para a análise dos textos orais, as entrevistas e os retornos foram gravados em áudio e transcritos segundo as normas de transcrição propostas pelo projeto NURC/SP (PRETI, 1999). A seguir, apresentamos um quadro com as categorias do modelo do ISD utilizadas nas análises, juntamente com as contribuições de Marcuschi (2001), Maingueneau (2011), Authier-Revuz (1998) e Bulea (2010):

\begin{tabular}{|c|c|}
\hline O contexto de produção do texto & $\begin{array}{l}\text { a) enunciador } \\
\text { b) destinatário } \\
\text { c) objetivo } \\
\text { d) momento } \\
\text { e) lugar social }\end{array}$ \\
\hline Infraestrutura geral do texto & $\begin{array}{l}\text { a) plano global do texto } \\
\text { b) tipos de discurso } \\
\text { c) sequências: sobretudo as sequências } \\
\text { dialogais, com base em Marcuschi (2001) }\end{array}$ \\
\hline Mecanismos de textualização & a) coesão nominal \\
\hline Mecanismos enunciativos & $\begin{array}{l}\text { a) modalizações } \\
\text { b) vozes: com base em Maingueneau (2011) e } \\
\text { Authier-Revuz (1998) }\end{array}$ \\
\hline Figuras de ação (BULEA, 2010) & $\begin{array}{l}\text { a) figura de ação ocorrência } \\
\text { b) figura de ação acontecimento passado } \\
\text { c) figura de ação experiência } \\
\text { d) figura de ação canônica } \\
\text { e) figura de ação definição }\end{array}$ \\
\hline
\end{tabular}

Quadro 12: Categorias do modelo de análise do ISD usadas para as análises dos dados de pesquisa

Os dados foram coletados, analisados e relacionados com as questões desta pesquisa à luz dos pressupostos teóricos. A seguir apresentamos as perguntas de pesquisa, 
os textos utilizados para respondê-las e as categorias do modelo de análise do ISD empregadas para as análises de cada texto:

\begin{tabular}{|c|c|c|}
\hline Perguntas & Textos & Categorias de análise \\
\hline $\begin{array}{l}\text { 1. Quais são as } \\
\text { prescriç̃̃es no trabalho } \\
\text { do professor iniciante de } \\
\text { língua estrangeira de um } \\
\text { curso extracurricular em } \\
\text { uma universidade de São } \\
\text { Paulo? Qual o seu papel? } \\
\text { São explícitas ou } \\
\text { implícitas? }\end{array}$ & $\begin{array}{c}\text { Guide du Moniteur, } \\
\text { Instruções ao Sósia e } \\
\text { Diários de aulas }\end{array}$ & $\begin{array}{l}\text { - Contexto de produção do texto } \\
\text { - Infraestrutura geral do texto } \\
\text { - Mecanismos de textualização } \\
\text { - Mecanismos enunciativos } \\
\text { - Figuras de ação }\end{array}$ \\
\hline $\begin{array}{l}\text { 2. Como o professor } \\
\text { iniciante concebe seu } \\
\text { trabalho? Quais são as } \\
\text { representações sobre seu } \\
\text { trabalho, sobre si } \\
\text { enquanto professor e } \\
\text { sobre os participantes da } \\
\text { situação de trabalho? }\end{array}$ & $\begin{array}{c}\text { Instruções ao Sósia e } \\
\text { Diários de aulas }\end{array}$ & $\begin{array}{l}\text { - Contexto de produção do texto } \\
\text { - Infraestrutura geral do texto } \\
\text { - Mecanismos de textualização } \\
\text { - Mecanismos enunciativos } \\
\text { - Figuras de ação }\end{array}$ \\
\hline $\begin{array}{l}\text { 3. Quais elementos } \\
\text { caracterizam a situação } \\
\text { de trabalho em um curso } \\
\text { extracurriculares de } \\
\text { francês? Quais são as } \\
\text { soluções encontradas pelo } \\
\text { professor para executar } \\
\text { seu trabalho nessa } \\
\text { situação? }\end{array}$ & $\begin{array}{c}\text { Instruções ao Sósia e } \\
\text { Diários de aulas }\end{array}$ & $\begin{array}{l}\text { - Contexto de produção do texto } \\
\text { - Infraestrutura geral do texto } \\
\text { - Mecanismos de textualização } \\
\text { - Mecanismos enunciativos } \\
\text { - Figuras de ação }\end{array}$ \\
\hline
\end{tabular}

Quadro 13: As questões da pesquisa e as categorias de análise. 


\section{CAPÍTULO III - RESULTADOS DAS ANÁLISES}

Este capítulo visa a apresentar os resultados obtidos pelas análises dos textos presentes no contexto de trabalho da professora participante da pesquisa e dos textos produzidos por essa professora em situação de trabalho. Para tanto, dividimos este capítulo em três seções. Na primeira seção, centramo-nos nos resultados da análise do Guide du Moniteur, documento que orienta o trabalho da professora participante, iniciante em FLE. Na segunda seção, trabalhamos com os resultados da análise dos quatro diários de aula produzidos pela própria professora. E, na terceira seção, dedicamo-nos aos resultados da análise de duas entrevistas de instrução ao sósia (IS) e seus retornos ${ }^{52}$.

\section{Análise do Guide du Moniteur}

Esta seção propõe expor os resultados da análise desenvolvida sobre o documento de orientação presente no contexto de trabalho de Mariana, ou seja, o texto que orienta seu trabalho nos cursos Extracurriculares de francês. Para isso, baseados no modelo de análise do ISD, proposto por Bronckart (1999/2009), dividimos esta seção em quatro subseções: a primeira busca compreender o contexto de produção do documento; a segunda mostra a análise da infraestrutura geral do texto; a terceira preocupa-se com os mecanismos de textualização e a última subseção propõe apresentar os mecanismos enunciativos presentes no texto.

\subsection{Contextos}

Primeiramente, analisamos o contexto de produção do Guide du Moniteur dos Cursos Extracurriculares de Francês sob ponto de vista físico (emissor, receptor, momento e lugar físico), em seguida, do ponto de vista sociossubjetivo (enunciador, destinatário, objetivo e lugar social) (BRONCKART, 1999/2009).

\footnotetext{
${ }^{52}$ Os dois textos de IS compreendem: instruções ao sósia de duas professoras e discussões relacionadas ao trabalho de ambas, já os dois textos de retorno às IS são compostos pela leitura dos comentários e discussões com as duas professoras. No entanto, analisamos as instruções de uma das professoras - Mariana - e os comentários e discussões, dando enfoque ao contexto de trabalho dessa professora.
} 
O Guide du Moniteur foi produzido na Faculdade de Filosofia, Letras e Ciências Humanas da Universidade de São Paulo, por um emissor não explicitado no texto, portanto, não há registro de quem assina o documento. Entretanto, no cabeçalho de todas as páginas há a referência de um órgão institucional que "responde" pelo documento, como mostra abaixo:

\section{FFLCH/USP - Serviço de Cultura e Extensão Cursos Extracurriculares de Francês}

É possível pensar, então, que este cabeçalho indica o emissor do texto - alguém que pertence ao contexto desse órgão institucional explicitado. O receptor do documento é evidenciado já no título "Guide du moniteur", indicando que o texto foi escrito para o monitor dos cursos Extracurriculares de francês. Para mais informações sobre esse documento de orientação, consultamos a dissertação de Mestrado de Menezes (2015), que, além de ser um dos monitores dos cursos Extracurriculares de francês, também analisou esse documento. De acordo com Menezes (2015), o Guide du Moniteur é encontrado em forma digital, em uma plataforma de comunicação (Tecno Moodle, plataforma disponível na USP) entre a coordenadora dos cursos e seus monitores ${ }^{53}$. Sua primeira versão tem data de julho de 2010, no entanto não é possível localizar essa informação no texto, a única referência que ele nos fornece é a data de sua versão atual, por nós analisada: agosto de 2013, encontrada no nome do arquivo (guide_du_moniteur_août2013).

Pela ótica do contexto sociossubjetivo, é possível dizer que o documento foi produzido por um enunciador que pertence ao contexto dos cursos Extracurriculares de francês, visto que, ao acolher o destinatário, demonstra já estar inserido no mesmo local. Para tanto, o enunciador faz uso de pronomes possessivos, como por exemplo em "nosso curso" e "nossa coordenadora" no excerto abaixo:

40 Dans ce guide vous trouverez des informations essentielles à propos de l'organisation

41 de notre cours. Pour plus d'information, vous pouvez toujours contacter notre

42 coordinatrice Eliane Lousada (elousada@usp.br) ou les assistants à la coordination :

43 Emily Caroline da Silva (emilycsilva@gmail.com) ou Simone Dantas

44 (simonedantas@gmail.com).

\footnotetext{
${ }^{53}$ Nos capítulos anteriores, usamos o termo professor-monitor, para deixar evidente os dois papeis do participante: o de professor, para os alunos e o de monitor, para a Universidade; nesta seção utilizaremos o termo monitor por ser o mais recorrente no Guide du Moniteur.
} 
O uso dos pronomes possessivos acompanhados dos termos "curso" e "coordenadora" implica o enunciador na situação de produção e permite levantar algumas hipóteses: i) o enunciador pode ser um monitor dos cursos Extracurriculares de francês; ii) o enunciador pode não ser a coordenadora, pois, provavelmente, ela não se trataria por "nossa coordenadora"; iii) a opção por escrever "os assistentes de coordenação", ao invés de nossos assistentes de coordenação (como em "nossa coordenadora"), levanta a hipótese de que o enunciador pode ser um dos (ou os dois) assistentes de coordenação.

Supondo que o enunciador seja um monitor e/ou um assistente de coordenação, imaginamos ser alguém mais experiente que os demais monitores, já que produziu um texto que orienta o trabalho dos monitores.

Para confirmar essas hipóteses, consultamos, mais uma vez, a dissertação Menezes (2015), conforme esse autor, o texto foi inicialmente produzido por uma monitora mais experiente, no entanto, ele sofreu e ainda sofre várias alterações desde sua primeira produção. $\mathrm{O}$ documento é regularmente modificado (a cada um ano, mais ou menos) por alguns dos monitores, principalmente por aqueles mais implicados no contexto dos cursos Extracurriculares de francês, ele também é verificado pela coordenadora dos cursos, ou seja, o Guide du Moniteur é produzido coletivamente por monitores, com o aval e as correções da coordenadora. Essas alterações são solicitadas pelos próprios monitores e/ou pela coordenadora, pois algumas informações precisam de atualizações. Com isso, a produção do Guide du moniteur pode ser vista como coletiva, ou seja, o documento teve um primeiro enunciador, depois foi e é alterado por vários coenunciadores. Portanto, compreendemos que há um macroenunciador do Guide du Moniteur que é representado por várias pessoas que o produziram e/ou o avalizaram monitores, ex-monitores, assistentes da coordenação e a coordenadora.

Os destinatários do Guide du Moniteur são os monitores recém-chegados aos cursos Extracurriculares de francês, mas também, aqueles que já estão há algum tempo no contexto de trabalho e que podem consultar esse documento para se lembrar de algumas informações. Com esse cenário, notamos que, de certa forma, os enunciadores desse texto prescritivo também são seus próprios destinatários. No entanto, nem todos os destinatários são enunciadores e, alguns dos enunciadores, não se colocam efetivamente como destinatários (como por exemplo, a coordenadora dos cursos).

No capítulo II, explicamos que para ser monitor dos cursos Extracurriculares de francês é preciso ter vínculo acadêmico, mais precisamente, ser aluno de pós-graduação 
na USP ou matriculado em curso de licenciatura ou bacharelado na FFLCH-USP. Isso significa que o Guide du Moniteur é destinado a alguém que já faz parte do contexto mais geral de sua produção - a universidade. O que nos faz pensar que esse destinatário pode já estar familiarizado com informações, espaços do ambiente de trabalho, com pessoas envolvidas com os cursos, entre outros. Esse é o caso de nossa participante da pesquisa, Mariana - monitora dos cursos Extracurriculares de francês, bacharela em Letras, com habilitação em português e francês, pela FFLCH da USP, mestranda pela mesma faculdade e aluna de licenciatura em Letras da Faculdade de Educação (FE) da USP. Vale ressaltar que a professora que orienta sua pesquisa de Mestrado também é coordenadora dos cursos Extracurriculares de francês.

No capítulo I, vimos que os textos prescritivos atendem tanto às demandas da instituição de trabalho quanto às necessidades dos trabalhadores, que precisam saber quais atividades devem desempenhar (GOIGOUX, 2002). A partir disso, vemos que o Guide du Moniteur foi produzido com o objetivo de facilitar aos monitores o acesso às informações, que anteriormente eram transmitidas oralmente, nas primeiras reuniões do semestre, com o coordenador dos cursos e os monitores (MENEZES, 2015). Abaixo, apresentamos um exemplo de como esse documento pode ajudar os recém-chegados. São os primeiros passos que o monitor deve seguir, caso ele não tenha uma conta bancária no Banco do Brasil.

\begin{tabular}{|l|l|}
\hline 52 & Documentation \\
53 & \\
54 & C'est votre première démarche à régler. Faites-la le plus tôt possible. \\
55 & Si vous n'avez pas un compte bancaire à la banque Banco do Brasil, prenez votre lettre de \\
56 & recommandation au Département Personnel (Serviço Pessoal - rhfflch@usp.br) au bâtiment \\
57 & de l'administration de la FFLCH..
\end{tabular}

Nesse excerto, as informações que auxiliam o monitor são: a documentação necessária para abrir a conta, onde consegui-la e o seu endereço eletrônico.

O Guide du moniteur não contribui apenas com os monitores recém-chegados, mas também com o órgão institucional que administra os cursos, assim, se os monitores estiverem bem informados sobre os passos a seguir, esse órgão institucional não terá grandes problemas para resolver neste contexto. 


\subsection{Infraestrutura geral}

Após o estudo do contexto de produção do documento de orientação para o trabalho da professora participante desta pesquisa, passemos para a análise da infraestrutura geral do texto, que compreende a organização dos conteúdos abordados no texto. O Guide du Moniteur é um documento escrito em francês em fonte Futura Bk, tamanho 12 no formato word. Ele é composto por 16 páginas, distribuídas da seguinte maneira: capa, sumário e seus conteúdos, que se organizam entre informações administrativas e pedagógicas dos cursos Extracurriculares de francês.

O texto é iniciado com um breve acolhimento aos novos monitores, seguido de uma sucinta explicação sobre o que o monitor encontrará no documento e os endereços eletrônicos ligados à coordenação dos cursos. Em seguida, são apresentadas questões sobre o âmbito administrativo, como os passos necessários para abrir e regulamentar uma conta bancária e sobre como é calculado o pagamento dos monitores. A próxima seção procura descrever o contexto de trabalho dos monitores, que inclui não apenas explicações sobre o trabalho ligado ao ensino (salas de aula, sala dos monitores, materiais pedagógicos etc.), mas também, sobre o contexto de trabalho no âmbito geral, como por exemplo, os espaços físicos que o monitor pode ocupar (a copa é um desses espaços).

Há ainda uma explicação sobre algumas etapas administrativas e etapas pedagógicas (reuniões, calendário etc.) dos cursos. Também encontramos informações sobre as avaliações e os testes de níveis dos alunos. Logo em seguida, há o pedido para a realização dos relatórios, que os monitores devem produzir e entregar à coordenação, além disso, encontramos os passos a seguir para continuar ou encerrar as atividades nos cursos Extracurriculares de francês. Por fim, o texto é encerrado com alguns contatos que podem ser úteis aos monitores.

Predomina no Guide du Moniteur o discurso interativo, portanto o texto pertence ao mundo discursivo do expor implicado. De acordo com Bronckart (1999/2009, p.168), a interação no discurso interativo é marcada pela predominância de frases não declarativas, ou seja, de frases interrogativas, imperativas e exclamativas. Não encontramos frases interrogativas no Guide du Moniteur, no entanto há um total de 05 frases exclamativas como "Soyez le(a) bienvenu(e)!" e "on est fiers de vous !", essas frases têm como objetivo encorajar o monitor recém-chegado, mas há também frases que o advertem, como por exemplo: “Attention!'. Localizamos ainda, um total de 44 frases 
imperativas no plano da ordem, como: "Prenez soin des matériaux et des équipements mis à votre disposition et n'oubliez jamais de fermer toutes les portes à clé".

O caráter conjunto implicado do Guide du Moniteur é caracterizado pela presença de nomes próprios, pronomes de primeira e segunda pessoa do plural que rementem aos protagonistas do texto:

\begin{tabular}{|l|l|}
\hline 8 & Pour plus d'information, vous pouvez toujours contacter notre coordinatrice Eliane \\
9 & Lousada (elousada@usp.br) ou les assistants à la coordination : Emily Caroline da Silva \\
10 & (emilycsilva@gmail.com) ou Simone Dantas (simonedantas@gmail.com). \\
\hline
\end{tabular}

Cinco nomes próprios aparecem no Guide du Moniteur, três estão ligados à coordenação dos cursos Extracurriculares de francês, um deles é da professora coordenadora e os outros são das assistentes de coordenação. Os outros dois são nomes de funcionários da Universidade (funcionário do departamento pessoal e da responsável pela Copa). Esses nomes representam alguns dos participantes da situação de trabalho de Mariana, que provavelmente estão presentes no texto por serem figuras importantes para o contexto de trabalho.

Os pronomes que remetem aos protagonistas no Guide du Moniteur são vous, nous e on. O vous indica os monitores recém-chegados, ou seja, o destinatário do texto. Esse pronome corresponde a segunda pessoa do plural e, em francês, pode indicar uma pessoa, em uma situação formal, ou mais de uma pessoa em um contexto tanto formal quanto informal. Nesse caso, por se tratar de um documento institucional, o texto traz traços de formalidade e o vous pode se referir a um ou mais monitores.

Os pronomes nous e o on indicam o macroenunciador, aquele que produziu e/ou avalizou o texto (monitores, ex-monitores, assistentes da coordenação e coordenadora). Esse enunciador ora inclui, ora exclui os monitores recém-chegados. Os excertos abaixo são exemplos de inclusão desses monitores:

74 Comme chaque cours a 45 heures par semestre et nous avons 15 heures de 75 réunion par semestre (3 heures de réunion par mois, 5 fois par semestre), votre 76 paiement mensuel peut être calculé selon l'équation suivante:

\begin{tabular}{|l|l|}
\hline 334 & Les élèves ne peuvent pas garder les évaluations. Après la \\
335 & correction, on les leur montre et on les garde dans notre armoire \\
335 & (mettez les évaluations dans une enveloppe avec votre nom, le \\
336 & niveau du groupe, l'horaire, la date et le semestre \\
337 & correspondant).
\end{tabular}


Percebemos que nesses dois casos os assuntos abordados estão diretamente ligados ao trabalho do monitor. De acordo com os excertos, os monitores têm 15 horas de reunião por semestre e não podem entregar as avaliações aos alunos, mas apenas mostrar e guardar. Diferentemente desses casos, as ocorrências dos pronomes on e nous, que não incluem o monitor recém-chegado, podem revelar o trabalho dos assistentes de coordenação, como por exemplo: encorajar e animar os recém-chegados ("on est fiers de vous !" - linha 395), organizar o trabalho de todo o grupo de monitores, entre outros.

A respeito das sequências, pode-se dizer que a mais empregada no Guide $d u$ Moniteur é a injuntiva, caracterizada pelas frases imperativas afirmativas ("Faites-la le plus tôt possible") e negativas ("N'oubliez pas de rejoindre notre espace virtuel"), pois possui um total de 44 ocorrências, como já dissemos. Na sequência injuntiva, o objetivo do agente produtor é fazer o destinatário agir (ou não agir) de um certo modo (BRONCKART,1999/2009).

A análise do contexto de produção e da infraestrutura geral do Guide du Moniteur possibilita algumas reflexões sobre esse documento de orientação. Uma delas diz respeito ao seu enunciador, o qual chamamos de "macroencunciador", pois é formado por seus produtores e avalizadores. Apesar desse "macroencunciador" compreender também a coordenadora (que o avalizou), fica claro que os enunciadores mais expressivos são aqueles que produziram esse texto: os monitores e ex-monitores. Essa afirmação pode ser confirmada pelo fato da coordenadora não estar indicada como enunciadora do que é enunciado ("nossa coordenadora").

Parece-nos interessante, também, pensar no caráter de proximidade entre enunciadores e destinatários do Guide du Moniteur. Isso ocorre porque, como vimos, os enunciadores do documento de orientação são monitores assim como seus destinatários. Os pronomes on e nous indicam um enunciador difuso, que ora se coloca separadamente dos monitores recém-chegados, ora se coloca junto deles. Esse fato mostra que não há uma separação tão acentuada entre os papeis ocupados no contexto de trabalho (todos são professores). Apesar dessa tentativa de atenuação do caráter prescritivo desse documento, as análises que apresentamos acima mostram que há tarefas prescritas aos monitores, dessa forma, como aponta Amigues (2004), existe uma hierarquia entre os monitores: os monitores mais experientes prescrevem a tarefa aos monitores recém-chegados. Vemos esse movimento de distanciamento do enunciador como fundamental para caracterizar o 
Guide du Moniteur como documento prescritivo, pois, de acordo com Amigues (2004), a tarefa dos trabalhadores é determinada por uma hierarquia.

Finalmente, ressaltamos o valor injuntivo desse documento de orientação, caracterizado pela grande quantidade de frases imperativas (44) que expressam ordem, conselho, sugestão, orientação, aviso etc. Assim, há um espaço reduzido para malentendidos, os destinatários podem identificar, com facilidade, o que é preciso (ou não) ser feito.

\subsection{Mecanismos de textualização}

Nossa pesquisa voltou-se para a análise do trabalho do professor iniciante e, como já dissemos, o perfil do monitor dos Extracurriculares de francês é de iniciante, por isso, nossa proposta nesta subseção foi de identificar como o monitor é abordado na progressão dos conteúdos temáticos do Guide du Moniteur. Sobre esse aspecto, identificamos como coesão nominal a predominância de alguns termos para referir-se: ao professor iniciante e ao métier de professor. Vimos na seção anterior, que os pronomes vous, nous e on podem indicar o monitor dos cursos Extracurriculares de francês, além deles encontramos os substantivos moniteur(s) e professeur(s). Para comparar e compreender seus usos no Guide du Moniteur, fizemos um levantamento da quantidade de cada um dos vocábulos e analisamos suas diferenças.

Comparando em quantidade o uso dos termos moniteur(s) e professeur(s), notamos que o Guide du Moniteur emprega com mais frequência o termo moniteur(s) (29 ocorrências), do que o termo professeur(s) (11 ocorrências). Isso pode revelar que, ainda que o Guide du Moniteur tenha sido produzido coletivamente por monitores e com o aval e as correções da coordenadora, que pertencem a uma esfera mais pedagógica do que administrativa, ele está integrado a uma instância institucional da Universidade, que não os considera como professores, mas como alunos e, portanto, monitores. Abaixo apresentamos um excerto retirado do Guide du Moniteur, em que fica claro como o monitor é reconhecido em seu contexto de trabalho fora da sala de aula:

\begin{tabular}{|l|l|}
\hline 158 & Vous avez le droit d'utiliser la Copa (par exemple : pour garder une marmite au \\
159 & frigo et la chauffer aux micro-ondes ou pour prendre un peu de café), mais \\
160 & n'oubliez pas de vous présenter à la responsable (Cida): dites que vous êtes \\
161 & moniteur aux Cursos Extras.
\end{tabular}


Nesse excerto, o enunciador do texto diz a seu destinatário para não se esquecer de se apresentar para a responsável pela Copa (Cida) e acrescenta a seguinte frase imperativa: "diga que você é monitor dos Cursos Extras". Essa frase deixa explícito como o professor é reconhecido pela universidade. Percebemos que o professor dos Extracurriculares de francês é visto como monitor não apenas pelo órgão institucional que administra os cursos Extracurriculares de francês, mas também por funcionários de outros setores presentes no dia-a-dia do monitor.

O termo professeur(s) presente no texto, pode estar associado ao métier de professor, como nos exemplos abaixo:

\begin{tabular}{|l|l|}
\hline 35 & C'est avec un grand plaisir que nous vous recevons dans le groupe des moniteurs des \\
36 & Cursos Extracurriculares de Francês. Nous espérons que vous profiterez de cette \\
37 & expérience pour échanger et interagir avec nous en vue d'apprendre ce beau métier \\
38 & de professeur de français. Soyez le(a) bienvenu(e)! \\
\hline 278 & Il y a une réunion à chaque mois, le vendredi de 9 h30 à 12h30. En général, les \\
279 & réunions sont composées de trois parties : les questions administratives; la formation \\
280 & des professeurs; ; la présentation d'activités. \\
\hline
\end{tabular}

Os vocábulos destacados estão ligados ao métier de professor. Assim, para manter o mesmo sentido não seria possível substituí-los por moniteur. De acordo com o dicionário francês virtual Larousse ${ }^{54}$, métier é uma atividade social que se define por seu objeto e suas técnicas. Se a atividade de um monitor de francês é a mesma de um professor de francês (ensinar a língua francesa), concluímos que não é possível dizer "métier de moniteur", já que é consolidado "métier de professeur". Com esse mesmo sentido, também não é possível falar em “formation de moniteur”, pois a formação não diz respeito às atividades específicas de um monitor, mas sim de um professor, neste caso, um professor de FLE.

Por outro lado, em outras passagens do texto, o enunciador ora opta por moniteur(s) ora por professeur(s) sem distinguir explicitamente as diferenças, como destacamos no excerto abaixo:

196 Dans le but de construire un fonds collectif d'activités, nous comptons sur la 197 collaboration de tous les moniteurs. Quand vous créez une activité pour votre 198 groupe, présentez-la dans nos réunions et/ou envoyez-la à Emily 199 (emilycsilva@gmail.com) et à Eliane (elianelousada@gmail.com) pour enrichir

\footnotetext{
${ }^{54} \mathrm{http} / / /$ www.larousse.fr/dictionnaires/francais/m\%C3\%A9tier/50997?q=m\%C3\%A9tier\#50887 (consultado 06/01/2016).
} 
200 notre fichier. Après une révision et mise en page, votre activité sera disponible en 201 ligne pour les autres professeurs. C'est à la fois une façon de diminuer le travail et 202 de partager vos idées avec les collègues.

Nas linhas 197 e 201, o enunciador inclui, em "todos os monitores" e "os outros professores", os monitores recém-chegados e os monitores mais antigos. Assim, os dois termos estão associados ao coletivo de trabalho, que é ora visto como um coletivo de professores, principalmente no contexto pedagógico (aluno, coordenação pedagógica etc.) e ora visto como um coletivo de monitores, sobretudo pelo contexto administrativo.

Com isso, entendemos que o monitor é abordado tanto como moniteur quanto professeur no texto analisado, sendo que o primeiro termo predomina, por se tratar de um texto ligado a um órgão institucional da universidade, que vê o monitor dos Cursos Extracurriculares de francês como aluno.

\subsection{Mecanismos enunciativos}

As modalizações predominantes no Guide du Moniteur são as chamadas deônticas que, conforme Bronckart (1999/2009, p.331), são apoiadas em valores, opiniões e regras do mundo social. Assim, o conteúdo do texto é apresentado como sendo do domínio da conformidade com as normas, do direito e da obrigação social.

Encontramos o verbo pouvoir - poder, em francês - conjugado na segunda pessoa do plural com o intuito de indicar aos monitores quais são seus direitos e possibilidades, ou seja, o que é permitido fazer dentro dos cursos Extracurriculares de francês. Assim, o enunciador comunica que os monitores têm o direito de:

- contatar três pessoas ligadas à coordenação para mais informações;

- abrir uma conta bancária universitária na própria faculdade;

- ter uma redução do valor do material didático, dependendo da editora;

- gravar os áudios do material didático utilizados nos cursos;

- consultar atividades preparadas em reuniões;

- imprimir as avaliações dos alunos de duas formas: pessoalmente, no local de impressão ou por e-mail. Os monitores podem se organizar para pedir cópias das avaliações, também, de dois modos: individualmente ou em grupos (verificando o número total de avaliações para impressão); 
- avaliar no meio do semestre todas as habilidades desenvolvidas pelos alunos ou dividilas em duas avaliações;

- ter uma longa permanência nos cursos.

Abaixo trazemos duas das ocorrências do verbo pouvoir conjugado na segunda pessoa do plural, que se encontram no domínio do direito e da possibilidade:

\begin{tabular}{|l|l|}
\hline 173 & Pour les acquérir, vérifiez avec la coordinatrice si vous pouvez bénéficier d'un \\
174 & spécimen (cela dépend des disponibilités des maisons d'édition). Vous trouverez les CD \\
175 & audio et les DVD dans l'armoire des moniteurs. Tous les enregistrements du CD sont \\
176 & également dans l'ordinateur portable de la salle des moniteurs, vous pouvez les \\
177 & copier sur votre clé USB ou sur un CD. \\
\hline 426 & De la même manière, vous pouvez être amenés à continuer pendant longtemps dans \\
427 & les cours extracurriculares de français [...] \\
\hline
\end{tabular}

Após uma primeira análise do uso do verbo pouvoir, percebemos que ele é empregado para demonstrar os direitos que os monitores têm dentro do contexto de trabalho, e, em alguns casos, as possibilidades (linha 426). O uso desse verbo pode indicar para o monitor certa flexibilidade ou até mesmo liberdade de escolha para o cumprimento de suas tarefas. No entanto, esses direitos não foram escolhidos aleatoriamente, vemos que os coenunciadores ofertam ao monitor direitos que, independente da escolha do monitor, não acarretarão problemas graves para a coordenação, nem para administração ou para os alunos. Em alguns dos casos, se a escolha não for adequada, pode prejudicar apenas o próprio monitor.

Encontramos ainda, como modalizações deônticas o uso do verbo devoir, que significa "dever" em francês, conjugado na segunda pessoa do plural no presente e no futuro e a expressão il faut também no presente e futuro, que pode ser traduzida como: é preciso, é necessário. $\mathrm{O}$ uso de ambos não está associado às possibilidades de escolhas do monitor, mas às orientações que ele precisa seguir. Provavelmente, se o monitor deixar de cumprir estas regras, ele próprio terá problemas, assim como a coordenação dos cursos, os alunos e o órgão institucional. Apresentamos abaixo algumas das ocorrências do verbo devoir e da expressão il faut conjugados na segunda pessoa do plural:

\begin{tabular}{|l|l|}
\hline 106 & Nos cours ont généralement lieu dans le bâtiment de Lettres, mais certains \\
107 & groupes peuvent éventuellement avoir cours d'autres bâtiments de la Faculté selon \\
108 & la disponibilité de salles. Vous devez informer le numéro de patrimoine de votre \\
109 & lecteur de CD aux gardiens à chaque fois que vous le sortez et le rentrez du \\
110 & bâtiment. \\
\hline 111 & Les salles de classe sont désignées par le Département de Lettres Modernes. Si \\
112 & jamais vous tombez sur une salle trop petite pour votre groupe, vous devez \\
113 & \\
\hline
\end{tabular}




\begin{tabular}{|l|l|}
\hline 114 & $\begin{array}{l}\text { contacter : le service de Cultura e Extensão (agenda@usp.br) et leur expliquer la } \\
\text { situation. }\end{array}$ \\
\hline 169 & - les copies des clés dont vous aurez besoin (il faut les rendre quand vous ne serez \\
170 & plus moniteur). \\
\hline 297 & Au cas où personne ne pourrait échanger un cours, vous devrez trouver avec les \\
298 & élèves une date ou quelques minutes avant ou après le cours pour rattraper les \\
299 & heures perdues (attention : il ne faut jamais déranger les activités et les horaires \\
300 & de la faculté ; il ne faut jamais porter préjudice aux élèves en diminuant leurs $45 \mathrm{~h}$ \\
301 & de cours par semestre). \\
\hline
\end{tabular}

A partir desse levantamento das modalizações deônticas encontradas no Guide $d u$ Moniteur, concluímos que a quantidade das modalizações ligadas aos deveres (17 ocorrências) é maior do que as ligadas aos direitos (11 ocorrências). Isso se justifica pelo fato de se tratar de um documento prescritivo, ou seja, um texto que diz o que o trabalhador deve fazer em seu contexto de trabalho.

Ainda no plano dos mecanismos enunciativos, identificamos algumas vozes que permeiam o texto que, de acordo com Bronckart (1999/2009), podem ser agrupadas em três categorias: vozes de personagens, vozes sociais e a voz do autor. Como já dissemos, não temos um único autor em nosso texto, mas várias pessoas que contribuíram para ele se tornar o que é atualmente.

A voz predominante no Guide du Moniteur é a voz dos coenunciadores (como já explicamos: o enunciador é representado por um "macroencunciador"). Essa voz acolhe e encoraja o monitor recém-chegado ("C'est avec un grand plaisir que nous vous recevons dans le groupe des moniteurs des Cursos Extracurriculares de Francês"), desejando que o monitor possa aproveitar desta nova experiência para aprender o métier de professor de FLE, já que neste contexto ele terá reuniões dedicadas à sua formação enquanto professor ("Nous espérons que vous profiterez de cette expérience pour échanger et interagir avec nous en vue d'apprendre ce beau métier de professeur de français”). Destacamos que essa voz se utiliza de uma modalização apreciativa para determinar o métier de professor como belo/bonito ("ce beau métier"), colaborando com a argumentação sobre as vantagens de ser monitor dos cursos Extracurriculares de francês.

A voz dos enunciadores pode se unir às vozes sociais, como por exemplo, à voz da instituição em que os cursos Extracurriculares de francês estão presentes (voz da faculdade e/ou da universidade). Neste caso, a união de vozes pode aparecer para advertir os monitores, para que eles não prejudiquem o andamento das atividades da faculdade, 
como as aulas de licenciatura, mestrado e doutorado. ("Attention! Les salles multimédia sont d'usage prioritaire des cours de licence, master et doctorat de la faculté. Ne les réservez pas plus de deux fois par semestre”).

Identificamos ainda, como vozes sociais, a voz do órgão institucional que regula e organiza os cursos Extracurriculares de francês ("Ouvrez un compte bancaire régulier à la banque Banco do Brasil (les comptes épargnes (poupança) ne sont pas acceptés). Vous pouvez ouvrir un compte Universitaire à l'agence Cidade Universitária". Essa voz pôde ser identificada pelo conteúdo veiculado e pela presença do nome do banco com o qual a instituição tem acordo: Banco do Brasil.

Outra voz identificada no texto foi a da didática de línguas estrangeiras, representada pelos termos que compõem o jargão da área da didática: compreensão oral e escrita, expressão e produção oral e escrita. A identificação do jargão da área é possível por meio da categoria proposta por Authier-Revuz (1998), através da qual notamos: “ $A$ chaque évaluation, on évalue la compréhension orale et écrite, l'expression et la production orale et écrite, chaque habileté (CO, CE, PO, PE) vaut $25 \%$ de la note totale. La première évaluation équivaut à $40 \%$ et la deuxième à $60 \%$ de la moyenne finale". Esses termos que compõe o jargão profissional são encontrados no documento que regula o ensino de línguas estrangeiras: o Cadre Européen Commun de Référence (CECR $)^{55}$. É interessante observar que há uma explicação de quais habilidades o monitor deve avaliar, no entanto, não podemos encontrar no texto uma explicação detalhada sobre essas habilidades. Acreditamos que há uma prescrição implícita no Guide du Moniteur: o monitor deve ter conhecimentos prévios das habilidades propostas pelo CECR.

Essas últimas seções sustentam a questão, já levantada, sobre a existência de uma proximidade que o Guide du Moniteur busca com seu destinatário, que pode ser vista:

i) pela presença de algumas frases exclamativas com tom amigável e às vezes humorístico, para encorajar o recém-chegado (“Soyez le(a) bienvenu(e) !”; "on est fiers de vous!");

ii) pela presença de pronomes usados pelo enunciador para, em alguns momentos, incluir seu destinatário ("nous avons 15 heures de réunion par semestre");

iii) pelas modalizações que expressam os direitos ou permissões ("vous pouvez les copier sur votre clé USB ou sur un CD");

${ }^{55}$ Quadro Europeu Comum de Referência (QECR). 
iv) pelo fato do enunciador se colocar às vezes como monitor, fazendo parte, assim, do coletivo de trabalho.

Diante disso, podemos dizer que essa proximidade visa a atenuar o caráter prescritivo do Guide que, no fundo, tem um lado injuntivo mais forte, pois, como vimos, apresenta mais ocorrência de frases imperativas e modalizações no campo dos deveres.

Compreendemos que o monitor dos Cursos Extracurriculares de francês precisa organizar seu trabalho. Sabendo disso, propomos apresentar na próxima seção os resultados das análises dos diários da professora-monitora participante desta pesquisa.

\section{Análise dos Diários de Aula}

Como já expusemos, o presente estudo propõe também apresentar uma análise dos diários de aulas produzidos pela professora iniciante na atividade docente, para refletir principalmente sobre como esse professor organiza seu trabalho.

Para isso, foram analisados quatro diários da professora participante que estava em seus primeiros anos de carreira, utilizamos como perspectiva teórica as ideias propostas pelo quadro teórico-metodológico do interacionismo sociodiscursivo (ISD) de Bronckart (1999/2009, 2006, 2008), sobretudo no que diz respeito à análise de textos do ISD e aos gêneros textuais.

\subsection{Contextos}

Pelo ponto de vista físico da situação de produção dos diários, podemos dizer que quem os escreveu foi Mariana, professora-monitora dos cursos Extracurriculares de francês. Por se tratar de um diário, Mariana escreve para ela mesma, sendo assim, ela é a própria receptora de seu texto. Seus diários foram produzidos nos dias 28 e 30 de março e 17 e 24 de abril de 2014, todos eles foram escritos em sua casa.

Pelo âmbito sociossubjetivo, a enunciadora dos diários pode assumir diferentes papeis dependendo da situação: professora, monitora, aluna etc. Acreditamos que para a produção dos diários, Mariana assume predominantemente o papel de professora dos cursos Extracurriculares de francês, visto que seus diários relatam suas experiências no ensino de FLE com uma determinada turma. No entanto, veremos adiante que Mariana 
pode assumir o papel de aluna, por exemplo, para refletir sobre algumas questões relacionadas ao seu trabalho.

Mariana tem bacharelado em português-francês e atualmente trabalha com o ensino de FLE, possivelmente, é vista como professora pelos seus alunos dos cursos Extracurriculares de francês. No entanto, seu contexto de trabalho está vinculado a uma universidade, onde ela exerce função de monitora; diferentemente dos professores da universidade, os monitores têm vínculo com a instituição como alunos e seus contratos como monitores são por tempo determinado. Com isso, além de ser vista pela universidade como monitora, também é vista como aluna de licenciatura em Letras e aluna do curso de Mestrado.

Os diários de aula de Mariana foram produzidos a pedido da professora que é, ao mesmo tempo, sua orientadora de pesquisa de Mestrado e coordenadora dos cursos Extracurriculares de francês. Sendo assim, não podemos desconsiderar a existência de uma hierarquia. A solicitação dos diários ocorreu no contexto de pesquisa de Mariana, e não no contexto dos cursos Extracurriculares de francês, logo no início de seu Mestrado em 2013, após sua decisão de estudar sobre o trabalho do professor. Antes mesmo de suas produções, Mariana já sabia que seus diários seriam analisados nesta pesquisa, que aborda o professor iniciante. Então, podemos dizer que as produções dos diários tiveram dois objetivos: em primeiro lugar, Mariana escreveu os diários para refletir sobre seu próprio trabalho, visto que sua pesquisa de Mestrado é voltada para isso, e, em segundo lugar, fornecer dados para esta pesquisa. É possível que esse último objetivo tenha se destacado mais, pois, como dissemos, a solicitação para a escrita do diário ocorreu em seu contexto de pesquisa, não no de trabalho.

A partir disso, pensamos em alguns possíveis destinatários dos diários de Mariana, como por exemplo, a professora orientadora/coordenadora, que tem dois diferentes contextos de relação com Mariana: de pesquisa e de trabalho docente. Eu também, como pesquisadora que busca analisar suas produções, sou uma provável destinatária do seu texto. Além disso, podemos utilizar os diários para apresentações e publicações de trabalhos acadêmicos, portanto, pressupomos que os textos de Mariana podem ainda ter como destinatários implícitos os leitores e/ou ouvintes interessados nos assuntos propostos por esta pesquisa. Para concluir a questão dos possíveis destinatários, percebemos que os diários de aulas podem ser destinados, ainda, para outros 
pesquisadores interessados em analisá-los, como, por exemplo, os integrantes do grupo de pesquisa, no qual fazemos parte.

Com isso, verificamos que os diários de aula tiveram como situação de produção o contexto acadêmico, o que provavelmente influenciou a produção escrita de Mariana, pois diferentemente de um diário íntimo, Mariana pode ter tomado mais cuidado com a linguagem, estilo, conteúdos abordados, entre outros.

\subsection{Infraestrutura geral}

Após refletirmos sobre o contexto de produção, passemos para a análise da infraestrutura geral do texto, que vai tratar da organização dos conteúdos temáticos presentes nos diários. Sabemos que as especificações, por parte de sua orientadora, de como deveriam ser os diários de aulas, foram sobre não os produzir mecanicamente a cada aula, mas escrevê-los a partir de aulas ou momentos mais significativos, que a fizessem refletir sobre seu trabalho. Isso significa que eles foram produzidos livremente, com característica principal de relatar as impressões sobre as aulas e as experiências vivenciadas em sala de aula.

Sobre a organização dos conteúdos, Mariana escreveu e organizou seus textos da maneira como achou melhor, pois não foi imposto um modelo a se seguir. Seus quatro diários foram escritos em francês no formato word, fonte Calibri e tamanho 11. Os diários ocupam duas páginas do documento intitulado "Journal des Cours Extras".

O primeiro diário está com a data de 28 de março de 2014, ele foi dividido em cinco parágrafos e cada um deles está organizado com os seguintes conteúdos temáticos:

\begin{tabular}{|l|l|}
\hline Parágrafos & \multicolumn{1}{c|}{ Conteúdos temáticos } \\
\hline Parágrafo 1 & início do semestre e novas turmas \\
\hline Parágrafo 2 & $\begin{array}{l}\text { alunos das novas turmas mais “fortes" que seus alunos do semestre anterior, } \\
\text { fato que a perturba }\end{array}$ \\
\hline Parágrafo 3 & $\begin{array}{l}\text { "menos trabalho" para a preparação de aulas, por já ter trabalhado no } \\
\text { semestre anterior com mesmo nível }\end{array}$ \\
\hline Parágrafo 4 & $\begin{array}{l}\text { comparação do desenvolvimento do trabalho no semestre anterior com o } \\
\text { semestre atual }\end{array}$ \\
\hline Parágrafo 5 & reflexão sobre a estratégia adotada para as explicações do conteúdo \\
\hline \multicolumn{1}{|c|}{ Quadro 14: Os conteúdos temáticos do diário de aula I de Mariana } \\
\hline
\end{tabular}

O diário de aula do dia 30 de março de 2014 está dividido em três parágrafos, com os conteúdos abaixo: 


\begin{tabular}{|l|l|}
\hline \multicolumn{1}{|c|}{ Parágrafos } & \multicolumn{1}{c|}{ Conteúdos temáticos } \\
\hline Parágrafo 1 & $\begin{array}{l}\text { reflexão sobre as aulas do semestre anterior e decisão de organizar, de outro } \\
\text { modo, os conteúdos a trabalhar }\end{array}$ \\
\hline Parágrafo 2 & explicação sobre como foi o novo modo de trabalhar os conteúdos \\
\hline Parágrafo 3 & $\begin{array}{l}\text { comparação do desenvolvimento das duas turmas; incompreensão do motivo } \\
\text { de não ter saído como planejado e reflexão sobre isso; explicação do que foi } \\
\text { feito e do que será feito }\end{array}$ \\
\hline
\end{tabular}

Quadro 15: Os conteúdos temáticos do diário de aula II de Mariana

O diário de 17 de abril foi escrito em dois parágrafos, cujos conteúdos são:

\begin{tabular}{|l|l|}
\hline Parágrafos & \multicolumn{1}{c|}{ Conteúdos temáticos } \\
\hline Parágrafo 1 & $\begin{array}{l}\text { avanço do conteúdo e a aproximação do exame; a importância da organização } \\
\text { do calendário no começo do semestre; sobre os alunos que faltam na prova e a } \\
\text { insatisfação com este fato }\end{array}$ \\
\hline Parágrafo 2 & $\begin{array}{l}\text { impressão de ter mais tranquilidade e clareza com a explicação dos conteúdos } \\
\text { gramaticais; reflexão se os alunos deste semestre são melhores ou se foi a } \\
\text { prática de ensino que melhorou }\end{array}$ \\
\hline
\end{tabular}

Quadro 16: Os conteúdos temáticos do diário de aula III de Mariana

O último diário, de 24 de abril de 2014, é constituído por um único parágrafo que aborda:

\begin{tabular}{|c|l|}
\hline \multicolumn{1}{|c|}{ Parágrafos } & \multicolumn{1}{c|}{ Conteúdos temáticos } \\
\hline Parágrafo único & $\begin{array}{l}\text { questão sobre a correção dos exercícios, mais precisamente, sobre a } \\
\text { insatisfação do momento da correção de exercícios de tarefa }\end{array}$ \\
\hline
\end{tabular}

Quadro 17: Os conteúdos temáticos do diário de aula IV de Mariana

O tipo de discurso predominante nos diários analisados foi o relato interativo, que se justifica pela presença de unidades que indicam disjunção (eixo do narrar), como as fórmulas temporais (o semestre passado quando, ontem, da outra vez) e os tempos verbais passé composé e imparfait, que, em português, correspondem ao pretérito perfeito e pretérito imperfeito respectivamente. Destacamos abaixo algumas destas características: 


\begin{tabular}{|l|l|}
\hline 22 & [...] je me suis souvenue que ça a été la folie le semestre dernier quand l'ai commencé à \\
23 & travailler le passé composé versus l'imparfait sans faire une bonne révision de chaque temps \\
24 & verbal séparément [...] \\
\hline
\end{tabular}

Diário de aula II

$35 \quad[. .$.$] Ensuite, j'ai commencé à travailler avec eux hier le passé composé versus l'imparfait, et cela$

36 n'a pas très bien marché comme je pensais [...]

Diário de aula II

15 [...] les comparaisons et la révision du passé composé ont mieux marché que de l'autre fois que

16 je les ai donnés semestre dernier. Mon tableau est aussi plus organisé, j'en suis fière quand on

17 fait la pause et je vois quelque chose de clair, schématisé.

Diário de aula I

Além disso, temos algumas unidades que indicam implicação, como o pronome je (eu) e suas formas verbais (acho, estava, tinha, tenho, posso) apresentadas em destaque:

\begin{tabular}{|l|l}
\hline 34 & {$[. .$.$] celles qui éxistaient étaient surtout par rapport aux participes passés, je pense.$}
\end{tabular}

Diário de aula II

3 Le semestre a commencé et de nouveaux groupes aussi, ce qui m’a encouragé parce que j'étais

$4 \quad$ un peu déjà fatiguée de ceux que j’avais le semestre dernier.

\section{Diário de aula I}

$5 \quad$ Ce semestre j'ai deux groupes du même niveau, niveau 4. Ils sont un peu différents mais j'ai

6 l'impression qu'ils sont plus forts que les élèves que j’ai eu au niveau 4 le semestre dernier - ce

7 qui m'inquiétait ou - je peux même dire - dérangeait un peu.

Diário de aula I

29 Ce qui m'a attiré l'attention ça a été que pas mal d'élèves n'avaient aucune idée de comment

30 conjuger les verbes pronominaux au passé composé et ils me l'ont dit lors de la correction. C'est

31 vrai qu'il a été un cours fatigant, j'étais épuisée à la fin, mais j’espère que cela aidera le bon

32 déroulement des prochains cours et leurs apprentissages.

Diário de aula II

De acordo com Machado (1998), a implicação do enunciador nos discursos é característica predominante nos diários. Acreditamos que esta implicação aproxima a enunciadora da situação relatada, sendo possível avaliar e refletir sobre suas atividades. No último excerto, por exemplo, Mariana relata seu cansaço por ter trabalhado com um conteúdo que apresentava dificuldade para os alunos, mas que só foi revelado durante a correção. Apesar de seu cansaço, Mariana espera que a aula tenha ajudado seus alunos.

Predominam nos diários de Mariana as sequências descritivas. Assim, ela descreve suas ações de trabalho (organização do calendário, conteúdo preparado, avaliações etc.), assim como, seu ambiente de trabalho, mais precisamente, os 
participantes do contexto de trabalho (seus alunos antigos e atuais etc.). Para exemplificar, retiramos dois excertos, o primeiro pertence ao diário I e o segundo, ao diário III.

\begin{tabular}{|l|l|}
\hline 5 & Ce semestre j'ai deux groupes du même niveau, niveau 4. Ils sont un peu différents mais j'ai \\
6 & l'impression qu'ils sont plus forts que les élèves que j'ai eu au niveau 4 le semestre dernier - ce \\
7 & qui m'inquiétait ou - je peux même dire - dérangeait un peu. \\
8 & J'ai déjà tous les cours préparés, ce qui est ravissant - moins de travail. C'est vrai que je sais qu'il \\
9 & y a des choses encore à améliorer, des activités qui n'ont pas très bien marché le semestre \\
10 & dernier, mais même avec cela c'est moins de travail que tout étudier, connaitre les règles pour \\
11 & bien les leur expliquer et trouver des activités intéressantes. \\
\hline 44 & À propos des cours, on avance avec le contenu parce que la date de l'examen partiel s'approche. \\
45 & J'aime bien organiser au début du semestre le calendrier avec les dates des examens écrits et \\
46 & oraux et aussi les activités extras - l'activité lecture, par exemple, pour dire en avance aux élèves \\
47 & pour qu'ils s'organisent. Si jamais il y a quelqu'un qui sait qui ne pourra pas être présent lors \\
48 & d'une de ces dates, je leur dis déjà pour me prévenir en avance pour que je reorganise ce que \\
49 & la personne va faire - venir à un de mes cours pendant la semaine ou à d'un collègue. C'est vrai \\
50 & que cette histoire de rater un examen ou une activité importante m'agace : je sais bien que \\
51 & chaque cas c'est un cas mais je n'ai pas le temps de prendre soin de la vie de tous les élèves, \\
52 & voilà pourquoi j'insiste qu'il faut vraiment faire des efforts pour ne pas rater les dates \\
53 & importantes du cours. \\
\hline
\end{tabular}

Diários I e III

\subsection{Mecanismos de textualização}

Quanto à coesão nominal, nos textos analisados, tentamos avaliar principalmente como se dá a retomada das figuras humanas principais dos textos. Verificamos os seguintes elementos principais:

\begin{tabular}{|l|l|}
\hline Enunciadora & je, moi, me, ma, mon, mes \\
\hline Aluno(s) & $\begin{array}{l}\text { il, ils, leur, leurs, eux, les, l'élève, les élèves, } \\
\text { nouveaux groupes, deux groupes, mon } \\
\text { groupe, la personne, vous }\end{array}$ \\
\hline Professores & un collègue \\
\hline Enunciadora e os alunos & On \\
\hline
\end{tabular}

Quadro 18: As figuras humanas presentes nos diários de aula

Abaixo, retiramos alguns excertos para exemplificação. No primeiro excerto, Mariana usa "meu grupo de sábado", referindo-se aos seus alunos. No segundo exemplo, a enunciadora está implicada em "para me prevenir" e em "minhas aulas". Mariana ainda indica os alunos com o pronome "lhes" e o substantivo "pessoa" e os outros professoresmonitores como "um colega". No último excerto, destacamos o uso do pronome francês "on" empregado como nosso "nós", que compreende os alunos e a professora. 
33 Avec mon groupe du samedi j'ai eu l'impression qu'ils avaient moins de difficultés [...] Diário de aula II

48 [...] je leur dis déjà pour me prévenir en avance pour que je reorganise ce que la 49 personne va faire - venir à un de mes cours pendant la semaine ou à d'un collègue [...]

Diário de aula III

72 [...] e leur ai déjà dit cela : " on a fait un accord : si vous n'avez pas fait l'exercice, tant 73 pis pour vous, faites-le au moment de la correction pour qu'on ne perde plus de 74 temps ». Je ne sais pas ce que les éléves pensent de cette attitude, ils font des visages 75 un peu sérieux, mais ça a été ça que j’ai juge le mieux à faire à ce moment-là.

Diário de aula IV

Com o objetivo de compreender o trabalho do professor iniciante pelo ponto de vista do próprio professor, aprofundamos a análise de como a enunciadora se refere a si mesma em seu texto. Além dos pronomes, já citados, observamos que a enunciadora se retoma no texto como aluna em dois momentos:

\begin{tabular}{|l|l|}
\hline 35 & Ensuite, j'ai commencé à travailler avec eux hier le passé composé versus l'imparfait, et cela n'a \\
36 & pas très bien marché comme je pensais. À mon avis, la différence d'usage de deux temps verbaux \\
37 & est bien claire, je ne sais pas pourquoi tant de questions. Je ne parle pas cela comme prof, mais \\
38 & si parce que je me rappelle quand j'étais étudiante de français et j'ai appris ce contenu, c'est \\
39 & comme en portugais. Bref, on a fait beaucoup d'exercices aussi et je leur ai demandé un texte à \\
40 & me rendre la semaine prochaine, pour que je voie s'ils commencent à maîtriser ce contenu ou \\
41 & non. Je compte à faire des activités orales pour travailler les deux temps verbaux ensemble, je \\
42 & dois encore y réflechir. \\
\hline
\end{tabular}

Diário de aula II

\begin{tabular}{|l|l|}
\hline 68 & Fraînchement (sic), je n'aime pas la correction d'exercices. J'ai la sensation que je rate le temps \\
69 & du cours où je pourrais faire des activités plus intéressantes et qui leur provoqueraient plus de \\
70 & progrès. Quand l'élève n'a pas fait l'exercice et me dit ça au moment de la correction, c'est encore \\
71 & pire. En tant qu'élève, quand je ne fais pas le devoir j'essaie de le faire au moment de la \\
72 & correction pour au moins y participer. Je leur ai déjà dit cela : « on a fait un accord : si vous n'avez \\
73 & pas fait l'exercice, tant pis pour vous, faites-le au moment de la correction pour qu'on ne perde \\
74 & plus de temps ». Je ne sais pas ce que les éléves pensent de cette attitude, ils font des visages un \\
75 & peu sérieux, mais ça a été ça que j'ai juge le mieux à faire à ce moment-là.
\end{tabular}

Diário de aula IV

Nesses dois excertos, a enunciadora se coloca na posição de aluna para se comparar com seus alunos, buscando refletir sobre o processo de ensino-aprendizagem. No primeiro exemplo, Mariana apresenta um problema: ela não compreende o porquê de tantas questões de seus alunos a respeito de um conteúdo que é claro. Para essa afirmação, ela assume o papel de aluna, não de professora: "eu não falo isso como prof, mas sim porque eu me lembro que quando eu era estudante de francês e aprendi esse conteúdo, é 
como em português". Diante desse problema, Mariana usa o passado para relembrar sua experiência enquanto estudante. Em busca de uma solução, ela expõe algumas alternativas, como exercícios escritos e orais e produção textual, no entanto, ela não parece satisfeita com isso: "eu devo ainda refletir"

Já no segundo exemplo, Mariana apresenta outro obstáculo para seu trabalho: ela não gosta da correção de exercícios e é ainda pior quando um aluno que não fez o exercício dizer que não o fez no momento da correção. Nesse caso, Mariana não se coloca no passado, mas assume o papel de aluna no presente, e assim, aproxima-se de seus alunos para fazer uma comparação: “Como aluna, quando eu não faço o exercício de casa eu tento fazêe-lo no momento da correção para ao menos participar". Diante do problema, Mariana apresenta uma estratégia utilizada para tentar solucioná-lo, ela fez um acordo com seus alunos: "eu lhes disse: 'façamos um acordo: se vocês não fizerem o exercício, pior para vocês, façam no momento da correção para que não se perca mais tempo"”.

Podemos interpretar essas soluções encontradas por Maniana com o que Saujat (2004) chama por recursos intermediários, ou seja, recursos elaborados por professores iniciantes para superarem as dificuldades ligadas ao não domínio de formas estáveis de agir dos professores mais experientes, que são consolidadas pelo meio profissional. Com isso, observamos que esses recursos são uma tentativa, não garantida, de superar os obstáculos. No diário IV, por exemplo, o acordo feito com seus alunos não garante que Mariana resolva os problemas abordados: o fato de ela não gostar da correção de exercícios e dos alunos não realizarem a lição de casa.

Parece-nos interessante destacar o movimento de reflexão feito por Mariana em seus diários: posicionar-se como aluna para refletir sobre o processo de ensinoaprendizagem de seus alunos. A experiência como aluno está presente, pois o professor iniciante está muito próximo de sua vida como aluno. Desse modo, podemos concordar com aafirmação de que diários produzidos por professores "reflete problemas sobre as construções feitas sobre o que é uma sala de aula e qual o papel do professor dentro dela" (Deen, 1987 apud LIBERALI, 1999).

Ainda pensando no trabalho do professor iniciante, verificamos como se apresenta a figura do métier de professor de FLE nos diários de Mariana. Para tanto, verificamos a coesão nominal e verbal ligadas ao métier de professor. Assim, identificamos predominância dos seguintes elementos destacados: 
8 J'ai déjà tous les cours préparés, ce qui est ravissant - moins de travail. C'est vrai que je sais qu'il y a

9 des choses encore à améliorer, des activités qui n'ont pas très bien marché le semestre dernier, mais

10 même avec cela c'est moins de travail que tout étudier, connaître les règles pour bien les leur

11 expliquer et trouver des activités intéressantes.

Diário de aula I

12 Il y a des contenus un peu délicait pour travailler au niveau 4 et je me sens, ce cette fois-ci, plus sûre

13 de moi pour les travailler avec les élèves, mes explication sont plus claires. Le semestre est encore

14 au début mais j'ai l'impression qui les cours où on a travailler le discours rapporté au présent, les

15 comparaisons et la révision du passé composé ont mieux marché que de l'autre fois que je les ai

16 donnés semestre dernier.

Diário de aula I

21 Quand j'ai planifié ce semestre en partageant les jours de cours et le contenu que je travaillerai dans

22 chaque séance, je me suis souvenue que ça a été la folie le semestre dernier quand l'ai commencé à

23 travailler le passé composé versus l'imparfait sans faire une bonne révision de chaque temps verbal

24 séparément. Alors, j'ai décidé de changer ce semestre et " perdre » des cours pour les réviser et

25 seulement ensuite travailler l'un versus l'autre. Aussi, je me suis rappellée qu'on va travailler bientôt

26 le « Plus-que-parfait » et il faut que les élèves aient les temps du passé déjà connus bien clairs pour

27 pouvoir bien avancer.

Diário de aula II

33 Avec mon groupe du samedi j'ai eu l'impression qu'ils avaient moins de difficultés avec le

34 passé composé que celui de la semaine, celles qui éxistaient étaient surtout par rapport aux participes

35 passés, je pense. Ensuite, j’ai commencé à travailler avec eux hier le passé composé versus

36 l'imparfait, et cela n'a pas très bien marché comme je pensais. À mon avis, la différence d'usage de

37 deux temps verbaux est bien claire, je ne sais pas pourquoi tant de questions. Je ne parle pas cela

38 comme prof, mais si parce que je me rappelle quand j'étais étudiante de français et j'ai appris ce

39 contenu, c'est comme en portugais. Bref, on a fait beaucoup d'exercices aussi et je leur ai demandé

40 un texte à me rendre la semaine prochaine, pour que je voie s'ils commencent à maîtriser ce contenu

41 ou non. Je compte à faire des activités orales pour travailler les deux temps verbaux ensemble, je

42 dois encore y réflechir.

Diário de aula II

No primeiro excerto, Mariana mostra que o fato de já ter a aula preparada faz com que ela tenha "menos trabalho". Em seguida, ela aponta o que poderia ser uma definição de trabalho para ela: "estudar, conhecer as regras para bem explicá-las e encontrar atividades interessantes". Com isso, temos como hipótese que, para o professor iniciante, conhecer bem a língua antes de ensinar, faz parte do seu trabalho, enquanto que, talvez, para um professor mais experiente, isso não apareça como parte de trabalho.

No segundo exemplo, Mariana revela estar mais segura naquele momento para explicar os conteúdos de determinado nível de turma do francês, do que no semestre anterior. Essa segurança se revela importante para o seu trabalho e parece estar associada ao fato de ser iniciante. O conteúdo a que ela se refere diz respeito aos aspectos linguísticos da língua francesa, assim como, no último excerto em que temos "eu comecei a trabalhar com eles ontem o passado composto versus o imperfeito, e isso não deu muito 
certo como eu imaginava"). Dessa forma, vemos que o conhecimento linguístico da língua ensinada é parte integrante do trabalho do professor iniciante.

Por fim, no terceiro excerto, identificamos que Mariana organiza seu trabalho em relação aos conteúdos linguísticos, como por exemplo, o "passé composé" e o "imparfait": ("eu organizei este semestre dividindo os dias de aula e o conteúdo que trabalharia em cada seção [...]").

O que esses excertos nos revelam é o que é considerado trabalho para Mariana, pois, fica clara a relação de trabalho com domínio dos conteúdos linguísticos, dominar esses conteúdos parece ser parte do trabalho do professor iniciante de língua estrangeira. Sendo assim, uma das características desse professor é a preocupação com o domínio da língua ensinada, visto que ele pode não ter tanta segurança quanto a isso ("je me sens plus sûre"). Além disso, os conteúdos linguísticos aparecem como um organizador da atividade desse professor, já que, como vimos, Mariana distribui as aulas de acordo com esses conteúdos. A estratégia utilizada por Mariana diante da insegurança do domínio dos conteúdos, é estudar, organizar os conteúdos linguísticos, redefinindo, assim, seu próprio trabalho. Nesse sentido, Amigues, 2004, p.52) ressalta que:

\begin{abstract}
as atividades de concepção, organização e regulação das diferentes situações fazem do professor um ator, um produtor de significação de situações e de finalização de sua própria ação que não corresponde absolutamente à imagem de um executor ou de profissão de média importância que lhe costuma atribuir.
\end{abstract}

\title{
2.4. Mecanismos enunciativos
}

A análise dos mecanismos enunciativos permite verificar como o agir dos envolvidos é avaliado por meio das vozes e modalizações (MAZZILLO, 2006). Neste caso, observamos a ocorrência de algumas modalizações que estão diretamente relacionadas com o trabalho da professora-enunciadora. Percebemos o uso mais frequente das modalizações apreciativas destacadas abaixo: 
8 J'ai déjà tous les cours préparés, ce qui est ravissant - moins de travail.

16 Mon tableau est aussi plus organisé, j'en suis fière quand on fait la pause et je vois

17 quelque chose de clair, schématisé.

Diário de aula I

44 À propos des cours, on avance avec le contenu parce que la date de l'examen partiel

45 s'approche. J'aime bien organiser au début du semestre le calendrier avec les dates des

46 examens écrits et oraux et aussi les activités extras - l'activité lecture, par exemple, pour

47 dire en avance aux élèves pour qu'ils s'organisent.

Diário de aula III

$63 \quad$ (...) Je ne sais pas si les élèves de ce semestre sont plus fort ou si moi, j'ai amélioré ma 64 pratique, mais vraiment j'ai l'impression que cela va mieux. Même mes tableaux sont 65 plus jolis et organisés, j'en suis fière.

66

Diário de aula III

68 Fraînchement (sic), je n'aime pas la correction d'exercices. J'ai la sensation que je rate le

69 temps du cours où je pourrais faire des activités plus intéressantes et qui leur

70 provoqueraient plus de progrès.

Diário de aula IV

A presença dessas modalizações, confirma o que Machado (1998) diz predominar nesse gênero "o universo temático da experiência pessoal, incluindo-se aí ações, sentimentos, sensações e pensamentos relacionados a essa vivência" (1998, p.28). Mariana faz uma avaliação positiva e negativa de questões relacionadas ao seu trabalho. Os julgamentos positivos dizem respeito a: suas aulas já preparadas, sua lousa mais organizada e a organização do calendário semestral, a respeito desse último, notamos que ele faz parte das prescrições presentes no documento de orientação para seu trabalho: "Élaborez avec les autres moniteurs du même niveau un calendrier pour le déroulement du semestre" (Guide du Moniteur, linha 269).

Os elementos organizacionais, como calendário e aulas preparadas, são apreciados positivamente por Mariana: ("eu gosto de organizar no início do semestre o calendário com as datas das avaliações escritas e orais e também as atividades extras"). Isso pode revelar a importância desses elementos no trabalho do professor iniciante. Ao mesmo tempo, preparar as aulas mostra ser algo muito importante, já que ter as aulas já preparadas é visto de forma positiva: ("eu já tenho todas as aulas preparadas, o que é maravilhoso - menos trabalho"). Isso também mostra que, de fato, o trabalho do professor extrapola a sala de aula, como já mostrado em outras pesquisas (LOUSADA, 2006; MACHADO, 2007) 
Por outro lado, encontramos uma avaliação negativa sobre uma outra prescrição/orientação, que não se encontra no Guide du Moniteur, mas aparecerá no retorno à segunda instrução ao sósia: a correção de exercícios. Ao invés de fazer a correção, Mariana diz que poderia fazer outras atividades mais interessantes e que estimulassem mais o progresso dos alunos. A correção de exercícios é uma prescrição/orientação implícita para o trabalho de Mariana, pois sabemos que ela faz parte do trabalho de um professor, está inscrita na memória transpessoal do métier (Clot, 2007). Mesmo que não esteja explícito em documentos oficiais ou manuais pedagógicos, os professores sabem que é preciso corrigir os exercícios. Isso significa que a correção está associada ao gênero profissional (CLOT et al. 2000), ou seja, são "formas de fazer mais ou menos difundidas na profissão" (FAÏTA, 2004, p.64). Talvez seja por esse motivo que Mariana realiza as correções, mesmo não lhe agradando.

Passando para a análise das vozes, encontramos três vozes distintas nos textos. A primeira é a voz da professora-enunciadora dos textos - Mariana. Como vimos na análise das modalizações, Mariana não apenas relata as experiências de ensino, mas comenta, avalia o que é enunciado no texto. A voz do enunciador é predominante nos diários, no entanto, outras vozes podem surgir para se unir à voz do enunciador, o que torna os diários polifônicos. Uma dessas vozes é a dos alunos, que aparece em dois momentos, ambos marcados pelo verbo discendi (dit) "eles me disseram" e "o aluno [...] me diz":

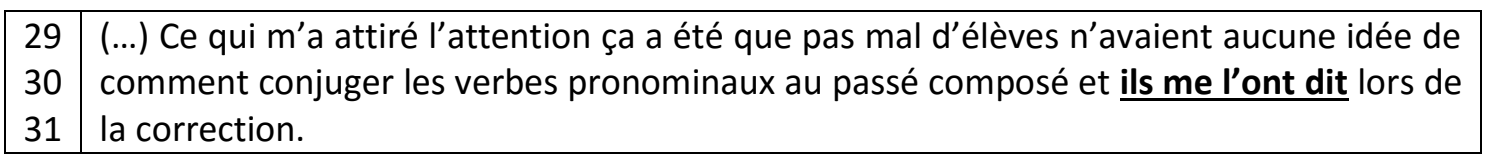
Diário de aula II

68 Fraînchement (sic), je n'aime pas la correction d'exercices. J'ai la sensation que je rate le 69 temps du cours où je pourrais faire des activités plus intéressantes et qui leur 70 provoqueraient plus de progrès. Quand l'élève n'a pas fait l'exercice et me dit ça au 71 moment de la correction, c'est encore pire.

Diário de aula IV

Nesse sentido, os diários de aula guardam semelhanças com os relatórios de estágio, já que, segundo Lousada (2011), a voz dos alunos está bastante presente nos relatórios. Sobretudo quando comparamos os diários e os relatórios de estágio com outros documentos, como os prescritivos, vemos que a voz dos alunos é muito mais presente nesses textos. 
Assim como no Guide du Moniteur, também foi possível verificar a voz da didática de línguas nos diários de Mariana. Essa voz está marcada pelo jargão (AuthierRevuz, 1998) do uso da metalinguagem (discours rapporté, comparaisons etc.):

$14 \quad[\ldots]$ j'ai l'impression qui les cours où on a travailler le discours rapporté au présent, les

15 comparaisons et la révision du passé composé ont mieux marché que de l'autre fois

16 que je les ai donnés semestre dernier.

Diário de aula I

Como dissemos no início desta seção, Mariana pode assumir alguns papéis (monitora, professora, aluna etc.), dependendo do contexto da situação. No caso dos diários, Mariana assume predominantemente o papel de professora, propondo algumas reflexões sobre a profissão. No entanto, identificamos nos diários de aula a voz da enunciadora na posição de aluna. Essa voz está indicada abaixo:

\begin{tabular}{|l|l|}
\hline 37 & [...] je ne sais pas pourquoi tant de questions. Je ne parle pas cela comme prof, mais si \\
38 & parce que je me rappelle quand j'étais étudiante de français et j'ai appris ce contenu, \\
39 & c'est comme en portugais [...] \\
\hline \multicolumn{2}{|c|}{ Diário de aula II } \\
\hline 71 & [...] En tant qu'élève, quand je ne fais pas le devoir j'essaie de le faire au moment de la \\
72 & correction pour au moins y participer [...]
\end{tabular}

Diário de aula IV

Explicamos esses dois excertos na análise dos mecanismos de textualização, quando abordamos sobre a retomada da própria enunciadora nos diários com o uso de "étudiante" e "élève". Aqui eles são retomados para entender o que a voz da enunciadora, enquanto aluna, expressa nesses diários. No primeiro exemplo, Mariana não sabe o motivo de tantas perguntas dos alunos sobre um determinado conteúdo, pois não há diferença desse conteúdo em português. No segundo excerto, Mariana explica que, enquanto aluna, quando ela não faz a tarefa, ela tenta fazer no momento da correção. $O$ que é interessante notar, nesse caso, é que Mariana utiliza o tempo presente do indicativo para falar sobre uma ação (não fazer a tarefa, fazer a tarefa na aula) que teria supostamente ocorrido no passado (quando era aluna). Percebemos, assim, o quanto a vida de aluna está presente no cotidiano da vida de professora de Mariana.

Nos dois casos, a voz da enunciadora enquanto aluna busca refletir sobre o ensinoaprendizagem de FLE. Esta reflexão está apoiada em exemplos da sua própria aprendizagem como ex-aluna e aluna. Imaginamos que, por ser professora iniciante, 
Mariana não deve ter experiências anteriores com muitos alunos, muitas classes para comparar com a situação atual, vivida em sala de aula. Sua experiência com aprendizagem de FLE mais próxima é como aluna e não como professora, o que explica a presença de sua voz enquanto aluna em seus diários.

\section{Análise das Instruções ao Sósia}

No capítulo II, explicamos os procedimentos para seleção dos dados da pesquisa, mostramos que dentre eles temos dois textos de entrevista de Instrução ao Sósia (IS) e dois textos de retorno às suas respectivas entrevistas de IS. Lembramos que cada texto de IS compreende as instruções de Mariana e uma discussão final. Nesta seção, temos como objetivo apresentar os resultados das análises desses textos, respeitando sua ordem de produção. Para isso, apresentaremos inicialmente o resultado das análises do texto da primeira entrevista de Instrução ao Sósia e seu retorno e, em seguida, o resultado das análises da segunda entrevista de Instrução ao Sósia e seu retorno ${ }^{56}$.

Como já afirmamos, analisamos os textos conforme o modelo de análise de textos proposto pelo quadro teórico do ISD de Bronckart (1999/2009). Para apresentarmos os resultados dessa análise, organizamos esta seção em subseções. Primeiramente, exporemos o contexto de produção das entrevistas. Para só, então, abordarmos a organização dos conteúdos temáticos tratados nos textos, os resultados das análises dos mecanismos de textualização e dos mecanismos enunciativos. Por fim, apresentaremos a análise das figuras de ação presentes nos textos.

\subsection{Primeira Instrução ao Sósia}

Iniciaremos a apresentação dos resultados da primeira IS e seu retorno, conforme explicado acima, pelo contexto de produção dos textos.

\footnotetext{
${ }^{56}$ Relembramos que as entrevistas de Instrução ao Sósia compreendem minhas instruções e as de Mariana, no entanto, nesta pesquisa centramo-nos apenas na análise das instruções de Mariana.
} 


\subsubsection{Contextos}

Nosso primeiro plano para a análise dos textos das entrevistas de Instrução ao Sósia (IS) e dos textos de retorno à IS é o contexto físico e o contexto sociossubjetivo de produção. No que diz respeito ao contexto físico, as entrevistas de Instrução ao Sósia e seus retornos tiveram como lugar de produção diferentes salas dos prédios da Faculdade de Filosofia, Letras e Ciências Humanas da Universidade de São Paulo (FFLCH/USP), três deles no prédio de Letras e um encontro no prédio de Filosofia. Nesta época, nós três cursávamos a mesma disciplina de pós-graduação, por isso os encontros foram marcados ou após as aulas ou após outros compromissos ligados ao curso de pós-graduação.

O momento de produção da primeira IS ocorreu no dia 30 de setembro de 2013, por volta das 15 horas, em uma sala do prédio de Letras. A entrevista completa tem duração de 1 hora, 24 minutos e 16 segundos, sendo que podemos dividi-la em três partes, que correspondem às minhas instruções, às de Mariana e à discussão final ${ }^{57}$. As instruções de Mariana duraram 30 minutos e 34 segundos, com início aos 26 minutos e 18 segundos da entrevista e as discussões finais duraram 27 minutos e 24 segundos.

O retorno à primeira entrevista de IS ocorreu quase dois meses depois da mesma, no dia 11 de novembro de 2013, por volta das 14 horas, em outra sala do prédio de Letras. A duração total do retorno à IS foi de 52 minutos e 51 segundos, os comentários de Mariana iniciam em 29 minutos e 37 segundos da gravação, há a leitura dos comentários de Mariana interrompidos por reflexão e discussão que se estende a uma discussão geral.

Os textos foram gerados por Flávia (que conduziu as entrevistas) por mim e Mariana (instrutoras das entrevistas). Dessa forma, no primeiro momento, eu fui a emissora do texto e Flávia e Mariana, as receptoras. No segundo momento, Mariana foi a emissora e eu e Flávia fomos receptoras. Já no terceiro momento, nós três assumimos o papel de ora emissoras ora receptoras do texto, isso ocorre no final das entrevistas de IS, que consiste em uma discussão logo após a entrevista, assim como, nos textos de retorno às IS, que se tratam de leitura dos comentários produzidos a partir das transcrições das IS e discussão.

Para melhor compreender o contexto de produção dos textos aqui apresentados, analisamos também o contexto sociossubjetivo, a começar pelo lugar social para geração

\footnotetext{
${ }^{57}$ Como já dissemos, esta pesquisa procurou analisar o contexto de trabalho de Mariana, portanto não analisamos minhas instruções e as discussões que envolvem o meu contexto de trabalho.
} 
dos dados. O espaço escolhido para os encontros é comum a nós três, por estarmos ligadas ao curso de pós-graduação da FFLCH. Com exceção da sala do prédio de Filosofia, todas as outras salas são espaços em que já tivemos aulas na pós-graduação, reuniões com o grupo de pesquisa, encontros individuais com nossa orientadora ou ainda participação em eventos. Para Mariana, o lugar é ainda mais familiar por ter estudado nas salas da FFLCH durante o curso de Graduação, além disso, as salas do prédio de Letras da FFLCH fazem parte do local de trabalho de Mariana, já que são usadas pelos cursos Extracurriculares de francês para as aulas de francês.

Como já explicamos, tanto eu quanto Mariana éramos professoras iniciantes de FLE e estudantes do curso de Mestrado e Flávia, professora de FLE desde 1996 e estudante de doutorado, todas matriculadas na mesma universidade no programa de pósgraduação. Nós três nos conhecemos no grupo de pesquisa ALTER-AGE, que é coordenado por nossa orientadora de pesquisa e tínhamos um contato mais frequente no período das entrevistas, pois cursávamos a mesma disciplina de pós-graduação.

Também explicamos que houve uma geração única de dados para duas pesquisas de Mestrado - minha e de Mariana. Essa proposta partiu de nossa orientadora, que fez o convite a Flávia, para assumir o papel de sósia, por ter uma experiência com os métodos de intervenção, mais precisamente, da autoconfrontação, utilizada em sua pesquisa de doutorado. Além disso, Flávia demonstrou interesse em conhecer melhor o método da IS para usá-lo posteriormente em formaçao de professores. Essa configuração faz com que Mariana saiba, antes mesmo das entrevistas, que suas instruções seriam analisadas por mim, assim como ela analisaria minhas instruções.

Sabendo dessa organização, podemos dizer que Mariana e eu somos as enunciadoras das entrevistas de IS, no entanto centramo-nos na análise das instruções de Mariana, assim como nas discussões sobre seu contexto de trabalho, reflexões, questionamentos etc. Apesar disso, não desconsideramos minha presença no momento da entrevista. Assim, Mariana é a enunciadora dos textos analisados, o papel social que desempenha durante as IS e seus retornos é de professora-monitora dos cursos Extracurriculares de francês, que hipoteticamente será substituída por seu sósia e precisa explicar o que ele deve fazer em seu contexto de trabalho. No entanto, não podemos desconsiderar os papeis sociais de Mariana no contexto universitário, já que eles podem influenciar na interação em curso. Como já dissemos, Mariana trabalha nos cursos Extracurriculares de francês desde 2013, durante a entrevista, tinha pouco tempo de 
experiência como docente. Ela é vista como professora-monitora para a universidade, mas para seus alunos seu papel é de professora. Além disso, ela é aluna de licenciatura e de Mestrado orientada pela professora que é ao mesmo tempo sua coordenadora, portanto Mariana possui diferentes papeis: monitora, professora e aluna que podem aparecer durante as entrevistas.

Mariana pode possuir vários destinatários nas IS e seus retornos. Durante o momento das entrevistas ela tem duas destinatárias: eu e Flávia. Podemos confirmar que Flávia é o destinatário direto pelo o uso dos pronomes que indicam a segunda pessoa do singular, como observamos logo abaixo em um excerto da primeira IS:

$10 \mathrm{M}$ : oui... bon je t'explique exactement ce que tu dois faire pour un groupe... samedi

$11 \mathrm{~S}: \mathrm{d}^{\prime}$ accord

Excerto da Primeira Instrução ao Sósia

Flávia (S) ${ }^{58}$, o destinatário explícito, tem o papel de sósia da IS, por isso, seu objetivo é de guiar as instruções de Mariana (M), isso se confirma pela introdução desta entrevista, que se apresenta da seguinte maneira:

$01 \mathrm{~S}$ : et alors on passe à :: Mariana... juste un moment... Mariana

$02 \mathrm{M}$ : [oui... oui

$03 \mathrm{~S}$ : on imagine la situation suivante...

$04 \mathrm{M}$ : [oui

$05 \mathrm{~S}:$ (...) demain je vais te remplacer...

$06 \mathrm{M}: \mathrm{d}^{\prime}$ accord

$07 \mathrm{~S}$ : (...) dans ta salle de classe... tu vas m'expliquer tout ce que je dois faire... pour que les gens ne se rendent pas compte...

$08 \mathrm{M}$ : d'accord

09 S : que tu es/que tu es remplacée par moi

Excerto da Primeira Instrução ao Sósia

Mariana precisa fornecer o máximo de informações sobre seu trabalho, pois ela é a única pessoa capaz de transmitir os detalhes mais precisos sobre sua atividade, enquanto Flávia deve prestar atenção nas instruções de Mariana e pedir-lhe o máximo de

\footnotetext{
${ }^{58}$ Usamos as seguintes legendas nas transcrições das IS e retornos: M: Mariana, S: Sósia e F: Fernanda
} 
informações para compreender o que é preciso ser feito para ter uma boa atuação durante a substituição hipotética do dia seguinte.

Como eu estou presente no momento das instruções de Mariana, posso ser vista como seu segundo destinatário, mas um destinatário implícito, já que não há nos textos de IS marcas de minha presença. Isso não ocorre nos textos de discussão e de retorno às IS, pois há marcas que indicam que sou, assim como a sósia, uma destinatária direta, como no excerto abaixo:

139M. tu y travailles toujours ou non ? a travaillé ? (sic)

140F. non... j'ai travaillé...

141M. d'accord

Excerto do Retorno à Primeira Instrução ao Sósia

Mariana se dirige diretamente a mim usando pronomes da segunda pessoa do singular (no exemplo acima "tu”), tanto nas discussões após à IS e no retorno.

Além disso, assim como os diários de aula, podemos pensar que Mariana pode ter ainda como destinatários (indiretos) outras pessoas que não estavam conosco no momento da IS e dos retornos, mas que ela sabia que teriam um contato futuro com seu texto, como por exemplo, pessoas que se interessam por questões ligadas à nossa pesquisa. Outro destinatário indireto é a professora que orienta os trabalhos acadêmicos de nós três. Ela tem papel significativo nesse contexto, pois além de orientadora do curso de Mestrado de Mariana é também coordenadora dos cursos Extracurriculares de francês. Assim, Mariana instruiu a sósia sabendo que sua orientadora/coordenadora teria acesso aos seus textos de IS, sobretudo porque a professora também é orientadora desta pesquisa.

É importante destacar que os enunciadores e os destinatários das discussões finais e do retorno são alternados entre as professoras-instrutoras e a sósia, visto que se trata de uma discussão.

Bronckart (1999/2009) define o objetivo de uma produção textual como o efeito que o texto pode causar no destinatário. Apoiamo-nos nessa definição para mostrar que Mariana pode ter vários objetivos, já que há diferentes destinatários (diretos ou indiretos) em seus textos. Assim, ela tem como objetivo principal, durante as instruções, fornecer as informações necessárias para que seu sósia possa compreender seu contexto de trabalho e as atividades desempenhadas. É necessário reconhecer, entretanto, que Mariana tem uma destinatária indireta (professora coordenadora/orientadora) que pode influenciar seus objetivos de produção devido à existência da relação hierárquica entre 
elas. Mariana sabia que esta professora teria acesso a seus textos e auxiliaria com análises, por ser também orientadora desta pesquisa. Com isso, imaginamos que Mariana pode ter direcionado as instruções pensando no que sua coordenadora/orientadora poderia e/ou gostaria de saber sobre seu trabalho.

\subsubsection{Infraestrutura geral}

Após a compreensão do contexto de produção dos textos de Instrução ao Sósia, passemos agora para a análise das IS a partir do ponto de vista do primeiro nível de análise: a infraestrutura geral do texto, que compreende o plano global e os tipos de discurso do texto.

É interessante observar que todos os textos foram gerados em língua francesa. Isso foi decidido antes da gravação da primeira IS, quando Flávia perguntou se preferíamos realizá-las em francês ou português; nós duas escolhemos o francês, por ser a língua utilizada em nosso contexto de trabalho.

A primeira entrevista de IS e o retorno à IS foram organizados da seguinte maneira: eu iniciei as instruções à sósia sobre o meu contexto de trabalho e Mariana acompanhou em silêncio; Mariana forneceu as instruções à sósia a respeito de seu trabalho, enquanto eu apenas observava; começamos uma discussão sobre as duas instruções, neste momento nós três questionamos tanto o meu contexto de trabalho quanto o de Mariana. No retorno à primeira IS, estruturamos deste modo: eu li meus comentários a respeito de alguns dos temas da IS; nós três discutimos as questões por mim levantadas; Mariana fez a leitura de seus comentários; discutimos esses comentários. Sabendo desta configuração, parece-nos importante apontar que Mariana foi a segunda enunciadora dos textos, por isso eles podem ter recebido algum tipo de influência da instrução anterior, como por exemplo, a escolha de alguns conteúdos abordados.

Sabendo que o plano global do texto corresponde à organização dos conteúdos abordados, ou seja, representa um "resumo" do texto, apresentamos a seguir o plano global dos conteúdos temáticos da primeira IS, da discussão e de seu retorno, assim como o enunciador e o turno que corresponde ao tema abordado: 


\section{Plano Global dos Conteúdos Temáticos da Primeira Instrução ao Sósia}

\begin{tabular}{|c|c|c|}
\hline Temas & Enunciador & Turno \\
\hline Situação hipotética de substituição no contexto de trabalho de Mariana & Sósia & $01 \mathrm{~S}$ \\
\hline $\begin{array}{l}\text { Chegada ao ambiente de trabalho (turma, dia e horário, sala dos } \\
\text { monitores, saudação) }\end{array}$ & Mariana & $10 \mathrm{M}$ \\
\hline Utilização do espaço comum dos monitores (o uso do armário) & Mariana & $54 \mathrm{M}$ \\
\hline $\begin{array}{l}\text { Percurso da sala dos monitores até a sala de aula (acompanhado de um } \\
\text { amigo) }\end{array}$ & Mariana & $82 \mathrm{M}$ \\
\hline $\begin{array}{l}\text { Chegada à sala de aula (alunos, organização do material, estratégia para } \\
\text { aguardar os alunos atrasados) }\end{array}$ & Mariana & $97 \mathrm{M}$ \\
\hline $\begin{array}{l}\text { Utilização de uma ficha preparada antes da aula (elaboração, suas } \\
\text { divisões, sua importância, o trabalho antes e depois da ficha) }\end{array}$ & Mariana & $137 \mathrm{M}$ \\
\hline $\begin{array}{l}\text { Correção dos exercícios de tarefa (modo de corrigir e como pedi-los aos } \\
\text { alunos) }\end{array}$ & Mariana & $221 \mathrm{M}$ \\
\hline $\begin{array}{l}\text { Explicação sobre o intervalo da aula (o momento de fazê-lo, sua } \\
\text { importância para os alunos e professor) }\end{array}$ & Sósia & $250 S$ \\
\hline Organização da segunda parte da aula & Sósia & $344 S$ \\
\hline O uso de jogos na sala de aula & Sósia & $350 \mathrm{~S}$ \\
\hline $\begin{array}{l}\text { Retomada do assunto a respeito da segunda parte da aula (organização } \\
\text { dos alunos, tempo para as atividades) }\end{array}$ & Mariana & $367 \mathrm{M}$ \\
\hline Explicação sobre o horário de término da aula & Sósia & $426 S$ \\
\hline $\begin{array}{l}\text { Retomada do tema sobre a importância do intervalo para os alunos e } \\
\text { professores }\end{array}$ & Sósia & $440 \mathrm{~S}$ \\
\hline Modos para encerrar a aula & Mariana & $529 \mathrm{M}$ \\
\hline Reflexão sobre a maneira como os alunos se despedem do professor & Mariana & $537 \mathrm{M}$ \\
\hline Procedimento para responder os e-mails enviados pelos alunos & Mariana & $557 \mathrm{M}$ \\
\hline Questão a respeito de elogiar os alunos & Sósia & $592 S$ \\
\hline $\begin{array}{l}\text { Existência de uma avaliação sobre o trabalho do professor, respondida } \\
\text { pelos alunos }\end{array}$ & Mariana & $603 \mathrm{M}$ \\
\hline Procedimentos de como guardar o material didático no armário & Sósia & $624 S$ \\
\hline
\end{tabular}

Quadro 19: Síntese do Plano Global dos Conteúdos Temáticos da $1^{\text {a }}$ Instrução ao Sósia

\section{Discussão da primeira Instrução ao Sósia}

\begin{tabular}{|l|l|l|}
\hline \multicolumn{1}{|c|}{ Temas } & Enunciador & Turno \\
\hline Explicação de como será a discussão & Sósia & $01 S$ \\
\hline Maneira como é realizada a preparação de aulas & Fernanda & $59 \mathrm{~F}$ \\
\hline Explicação sobre o que é o "tutorat” & Mariana & $65 \mathrm{M}$ \\
\hline Discussão sobre a organização do tempo para as atividades & Mariana & $76 \mathrm{M}$ \\
\hline Diferenças entre um professor de outro & Mariana & $106 \mathrm{M}$ \\
\hline Oganização da lousa & Mariana & $223 \mathrm{M}$ \\
\hline $\begin{array}{l}\text { Língua usada para comunicação entre os professores de língua } \\
\text { estrangeira }\end{array}$ & Mariana & $276 \mathrm{M}$ \\
\hline
\end{tabular}

Quadro 20: Síntese do Plano Global dos Conteúdos Temáticos da Discussão da $1^{\text {a }}$ Instrução ao Sósia 


\section{Retorno à primeira Instrução ao Sósia}

\begin{tabular}{|l|l|l|}
\hline \multicolumn{1}{|c|}{ Temas } & Enunciador & Turno \\
\hline Organização dos alunos para atividades conjuntas & Mariana & $196 \mathrm{M}$ \\
\hline Despedida dos alunos com um beijo no rosto do professor & Mariana & $198 \mathrm{M}$ \\
\hline Papel do aluno e do professor na sala de aula & Mariana & $200 \mathrm{M}$ \\
\hline Retomada do assunto sobre organização dos alunos em grupos & Mariana & $208 \mathrm{M}$ \\
\hline Reflexão sobre o professor como uma autoridade em sala de aula & Mariana & $227 \mathrm{M}$ \\
\hline $\begin{array}{l}\text { Oposição entre como Mariana se vê nas instruções ao sósia e como se vê } \\
\text { na sala de aula }\end{array}$ & Mariana & $241 \mathrm{M}$ \\
\hline Reflexão a respeito da utilização da língua francesa entre os professores & Mariana & $284 \mathrm{M}$ \\
\hline Uso do armário da sala dos monitores & Mariana & $309 S$ \\
\hline Divisão da aula antes e após o intervalo & Mariana & $320 \mathrm{M}$ \\
\hline $\begin{array}{l}\text { Retomada do fato dos alunos se despedirem do professor com um beijo } \\
\text { em seu rosto }\end{array}$ & Mariana & $330 \mathrm{M}$ \\
\hline Liberdade entre alunos e professor & Mariana & $336 \mathrm{M}$ \\
\hline Maneira como Mariana gostaria de ser vista por seus alunos & Mariana & $352 \mathrm{M}$ \\
\hline As relações entre Mariana e seus alunos & Mariana & $359 \mathrm{M}$ \\
\hline
\end{tabular}

Quadro 21: Síntese do Plano Global dos Conteúdos Temáticos do Retorno à $1^{\text {a }}$ Instrução ao Sósia

Depois desse estudo sobre o plano global do texto, abordaremos os tipos de discurso presentes no texto. A Instrução ao Sósia pertence ao gênero textual entrevista ${ }^{59}$. Como já dissemos no capítulo II, esta entrevista foi gravada e transcrita, nossa análise foi feita a partir do texto transcrito. O gênero entrevista é articulado em uma situação de ação de linguagem implicada pelos interlocutores que alternam o turno em um espaço de tempo comum (Bronckart, 1999/2009). Com isso, observamos que há uma prevalência do discurso interativo, ou seja: do mundo do expor implicado.

O discurso interativo, neste texto, é o que Bronckart (1999/2009) define por "primário", em que a fala é tomada diretamente pelos interlocutores caracterizados por marcas de referências, como je, tu, on, nous e suas formas verbais.

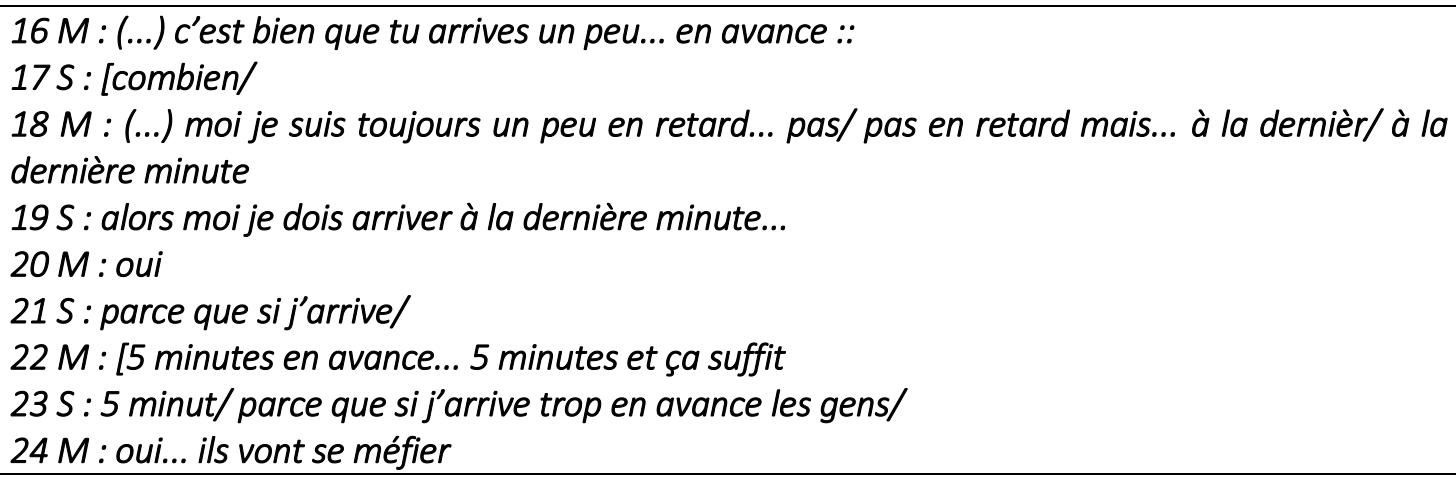

${ }^{59}$ Adotamos a noção de gênero textual de Bronckart (1999/2009) 
Nesse excerto, podemos ver que Mariana faz o uso do "tu" para instruir a sósia; essa técnica da entrevista de Instrução ao Sósia colabora para que o sujeito - no caso o professor - se coloque no lugar do outro, para que ele possa ver, com outros olhos, sua atuação em situação de trabalho (SAUJAT, 2005). No entanto, como mostra esse excerto, durante a IS Mariana muda algumas vezes o "tu" para o "je"; nesses momentos, a professora deixa de instruir a sósia para dizer o que ou como ela faz no contexto de trabalho, aproximando-se da situação relatada.

Há 194 ocorrências do "je”" na primeira IS, sendo que 66 são de Mariana e 128 da sósia. Isso nos indica que a sósia insistiu na retomada da situação de instrução, como no excerto abaixo:

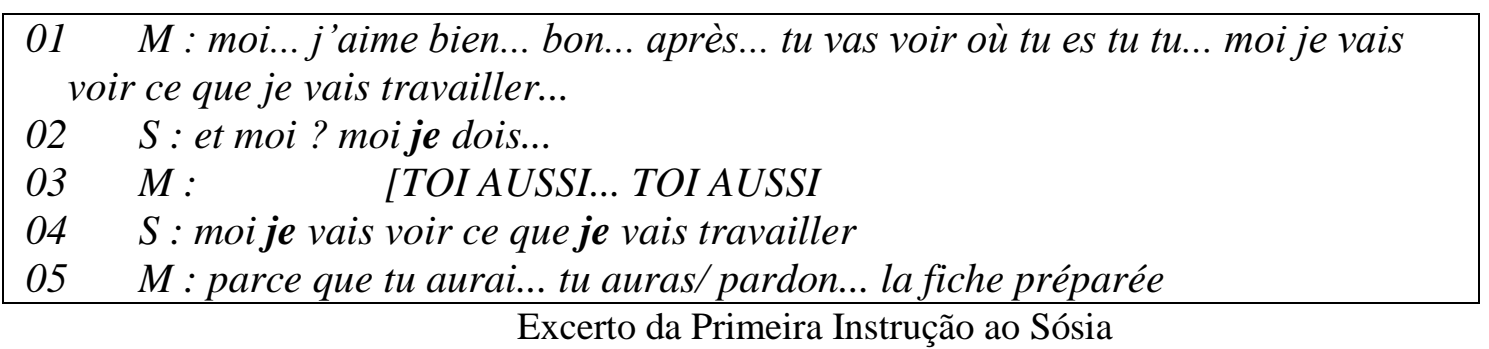

Apesar de 66 ocorrências de "je" nas instruções de Mariana, há 220 usos de "tu" na entrevista de instrução ao sósia, sendo que apenas 3 deles são da sósia, que os utiliza no início da entrevista quando introduz a substituição hipotética. Com isso, podemos dizer que o método de IS foi bem empregado ${ }^{60}$, visto que o objetivo principal é fazer com que o professor/instrutor veja com os olhos de outro suas experiências, para tanto, a linguagem é dirigida a outro (“tu”) (CLOT, 2001).

Constatamos também uma forte presença do relato interativo (mundo do narrar implicado), principalmente, quando Mariana faz referências às situações sobre o seu trabalho situadas no passado:

$200 \mathrm{~S}$ : ah, d'accord

$201 \mathrm{M}$ : mais... c'est vrai que là... je suis un peu plus habituée mais avant... enfin... quand j'étais/ quand j'ai vraiment commencé à faire cours... je notais tout... exactement... 202 S : uhn uhn

Excerto da Primeira Instrução ao Sósia

${ }^{60} \mathrm{O}$ método de IS foi utilizado conforme sugerido pelos pesquisadores da Clínica da Atividade e Ergonomia da Atividade. 
O uso de "avant" (antes, em português) seguido do emprego do passado composto e do imperfeito destaca a distância entre o mundo discursivo e a ação da linguagem.

Por se tratar de textos nos quais predomina o discurso interativo, em que os interlocutores estão engajados em uma conversação, observamos que todos os textos se organizam em uma sequência dialogal (Bronckart, 1999/2009). Os textos são estruturados em turnos de fala assumidos pelos interlocutores dos textos, de modo que nas instruções os turnos são alternados entre a instrutora (Mariana) e a sósia (Flávia), já no excerto de discussões da IS e no texto de retorno os turnos são divididos entre mim, Mariana e a sósia, como mostra a tabela abaixo:

\begin{tabular}{|l|l|l|l|l|}
\hline $\begin{array}{l}\text { 1a IS e } \\
\text { Retorno à 1a IS }\end{array}$ & Mariana & Sósia & Fernanda & Total de turnos \\
\hline $\begin{array}{l}\text { Instruções de } \\
\text { Mariana }\end{array}$ & 325 turnos & 324 turnos & -- & 647 turnos \\
\hline Discussão & 115 turnos & 55 turnos & 127 turnos & 298 turnos \\
\hline Retorno à 1a IS & 140 turnos & 151 turnos & 94 turnos & 385 turnos \\
\hline
\end{tabular}

Sabendo que a tomada de turno obedece técnicas e regras (MARCUSCHI, 2001), consideramos, as duas regras abordadas por Marcuschi (2001, p.20) para compreender os turnos da IS e seu retorno:

- Técnica I: o falante corrente escolhe o próximo falante, e este toma a palavra iniciando o próximo turno;

- Técnica II: o falante corrente para e o próximo falante obtém o turno pela autoescolha.

A IS desenvolve-se da seguinte maneira: a sósia escolhe a instrutora Mariana, que, por sua vez, toma a palavra desenvolvendo os próximos turnos, que são intercalados de duas formas: por sobreposição de vozes da sósia, que ocorre quando esta concorda com Mariana (“sim”, “tá bom”, "é”, “ahã”, “claro” etc.) e por questionamentos, característicos do método de IS (por exemplo: como eu explico isso?). Já nas discussões, na IS e em seus retornos, os turnos são tomados com a combinação das duas regras desenvolvidas por Marcuschi (2001):

a) Mariana escolhe Fernanda pela técnica I; Fernanda escolhe Mariana pela técnica I; A sósia escolhe ora Mariana ora Fernanda pela técnica I; 
d) Mariana ou Fernanda ou a sósia não escolhe a técnica I, então qualquer participante autoescolhe-se pela técnica II;

e) Mariana ou Fernanda ou sósia não escolhe o próximo e nenhum outro falante se autoescolhe, então Mariana ou Fernanda ou sósia pode prosseguir falando.

A função dos turnos da sósia é pedir explicações, explicitações à instrutora, portanto parte dos atos de fala da sósia é composta por questões. Além disso, muitos dos turnos da sósia têm como função concordar com a instrutora: "uhun", "ahan", "d'accord" etc. A instrutora, por sua vez, precisa explicar com detalhes o que a sósia deve fazer para substituí-la. Com essa configuração, fica evidente que a instrutora tem turnos mais longos que os da sósia. Nos textos em que há o debate (trecho da discussão e texto do retorno), a função do enunciador não é mais instruir a sósia, mas refletir, juntamente com o coletivo, sobre sua atividade de trabalho e a atividade do outro professor/instrutor. No quadro acima, vemos que os turnos de falas são bastante variados.

Em alguns turnos de fala, encontramos algumas pausas não-sintáticas (MARCUSCHI, 2001), mais precisamente, as hesitações, que podem ser identificadas, por exemplo, por pausas, repetições, dúvidas etc. Acreditamos que nesses momentos pode haver uma reflexão do que se fala sobre o trabalho, ou talvez, uma tomada de consciência, a exemplo do que nos apresentam Lousada e Dantas-Longhi (2011). Para exemplificar, retiramos um excerto da primeira IS em que Mariana explica o que sua sósia deve fazer no final da aula. O que nos interessa é observar quando Mariana relata que os alunos vão se despedir da sósia com beijos no rosto. Neste momento, ela revela achar estranha esta situação:

$537 \mathrm{M}$ : tu prends tes/ tu prends tes affaires... tu prends ton sac... tu tu mets des choses là dedans... les plus sympa... vont te dire " au revoir "... vont te faire la bise...

$538 \mathrm{~S}:$ uhn

$539 M:(.$.$) ça c'est bizarre$

540 s: uhn?

$541 \mathrm{M}:$ tu... mais tu dois...

$542 \mathrm{~S}$ : ils vont faire la bise et moi je trouve ça bizarre?

$543 \mathrm{M}$ : oui oui oui oui oui... beaucoup de/ beaucoup d'amour ((risos))

$544 \mathrm{~S}:$ uhn

$545 \mathrm{M}$ : mais... tu tu ((risos)) tu vas le/ tu vas les remercier... tu vas leur dire... " ah oui... c'est gent/ $546 \mathrm{~S}$ : [je vais faire la bise quand même?

$547 \mathrm{M}$ : oui parce que... oui ((risada))

548 S : d'accord

Excerto da Primeira Instrução ao Sósia 
Após essa revelação, vemos que Mariana tem várias hesitações: ela tenta retomar a instrução, mas não segue adiante, apresentando duas pausas (linha 541); depois disso, ela exprime muitas repetições e aparecem mais pausas (543 e 545), ao tentar justificar seu estranhamento e ao voltar à instrução ao sósia; por fim, há a introdução do que seria uma explicação para a questão da sósia (547), mas Mariana não deu prosseguimento. Essas hesitações preenchidas (MARCUSCHI, 2001) com reduplicações (“oui oui oui oui oui... beaucoup del beaucoup d'amour"), podem ser interpretadas como um momento de reflexão, em que Mariana busca entender o motivo de achar estranho a maneira como os alunos se despedem. Podemos levantar a hipótese de que ela começa a ver a situação e ela mesma de um ponto de vista externo, o que pode estar na base de uma tomada de consciência.

No texto de retorno à IS, Mariana retoma este tema abordado revelando um paradoxo: ela gosta e acha gentil os alunos se despedirem com um beijo em seu rosto, mas ainda acha estranho. Na IS Mariana parece não entender o motivo de achar estranho este gesto, assim, as hesitações funcionam como "organização e planejamento interno do turno e dão tempo ao falante de se preparar" (MARCUSCHI, 2001), neste caso, elas podem indicar a busca por uma explicação, que talvez apareça no retorno à IS: ela nunca se despediu de seus professores com beijo no rosto:

332.M. ça c'est vrai j'ai pas changé... mais le truc-là de reine je sais pas quoi... ils me font la bise... j'aime bien ça... c'est c'est c'est gentil

333.S. oui

334.M. mais c'est bizarre quand même... j'ai jamais fait des bises... à mes profs...

Excerto do retorno à primeira instrução ao sósia

Nesse excerto, podemos compreender o que Saujat (2005) afirma quando menciona que a IS é um momento em que o professor/instrutor passa a se ver de um ponto de vista externo, já que Mariana dá a entender que nunca havia pensado nesse fato antes. É possível compreendermos esse distanciamento como um início de tomada de consciência, já que, para Clot (2001), baseado em Vigotski (1997), a consciência é a experiência vivida de uma experiência vivida. Tomar consciência, para Clot (2001, p.24) não é encontrar um passado intacto, mas fazer com que o passado seja revivido em novo contexto, na ação presente. 


\subsubsection{Mecanismos de textualização}

Sobre a coesão nominal, observamos o uso dos pronomes pessoais e sintagmas nominais que representam os interlocutores e outros indivíduos citados na entrevista.

A enunciadora - Mariana - é retomada pelos pronomes de primeira pessoa do singular (je, moi):

$10 \mathrm{M}$ : oui... bon je t'explique exactement ce que tu dois faire pour un groupe... samedi $11 \mathrm{~S}:$ d'accord

Excerto da Primeira Instrução ao Sósia

196. S. tu lis aussi les commentaires

197. M. d'accord... Bon.. le passage qui m'a attiré le plus mon attention a été celle où on parle du cours juste après la pause... quand on fait des exercices en groupe... à deux... etc... moi j'ai dit... moi Mariana... " moi, ce que j'ai apperçu et tu peux faire c'est des discussions et aussi des...

Excerto do Retorno à Primeira Instrução ao Sósia

A sósia, quando indicada no texto por ela mesma, faz o uso de pronomes de primeira pessoa do singular (je, moi), no entanto ela é retomada pela enunciadora por pronomes de segunda pessoa do singular (tu, toi).

108 S : ah... d'accord... je dois avoir une conversation... avec des argots :: des mots comme ça... $109 \mathrm{M}$ : [oui parce quel

$110 \mathrm{~S}:$ (...) pour animer la conversation ?

$111 \mathrm{M}$ : oui... pendant la conversation tu ranges tes affaires

$112 \mathrm{~S}$ : ah... je parle en m'organisant les trucs?

Excerto da Primeira Instrução ao Sósia

Também encontramos sintagmas nominais que nos auxiliaram a identificar as representações da professora participante da pesquisa sobre si mesma, sobre seus alunos e seu contexto de trabalho, mais especificamente, a sala de aula. Tanto na primeira IS quanto em seu retorno, aparece a figura da "rainha" para representar a professora, a figura dos "subordinados" representando os alunos e "uma pequena sociedade" indicando as relações entre esses sujeitos em sala de aula. Na primeira IS, Mariana explica que a sósia receberá e-mails enviados por alunos para tirar dúvidas. Assim, a sósia é instruída a não responder esses e-mails e dizer aos alunos a levarem as dúvidas para sala de aula. A partir disso, Mariana explica que há um acordo com os alunos, apesar de não explicitar esse 
acordo, acreditamos que se trata dos alunos não enviarem as dúvidas por e-mail, mas perguntarem na aula. Após isso, Mariana propõe algumas metáforas: "a sala de aula é uma pequena sociedade [...] você é a rainha dessa sociedade [...] e os outros... eles são os:: um pouco os subordinados":

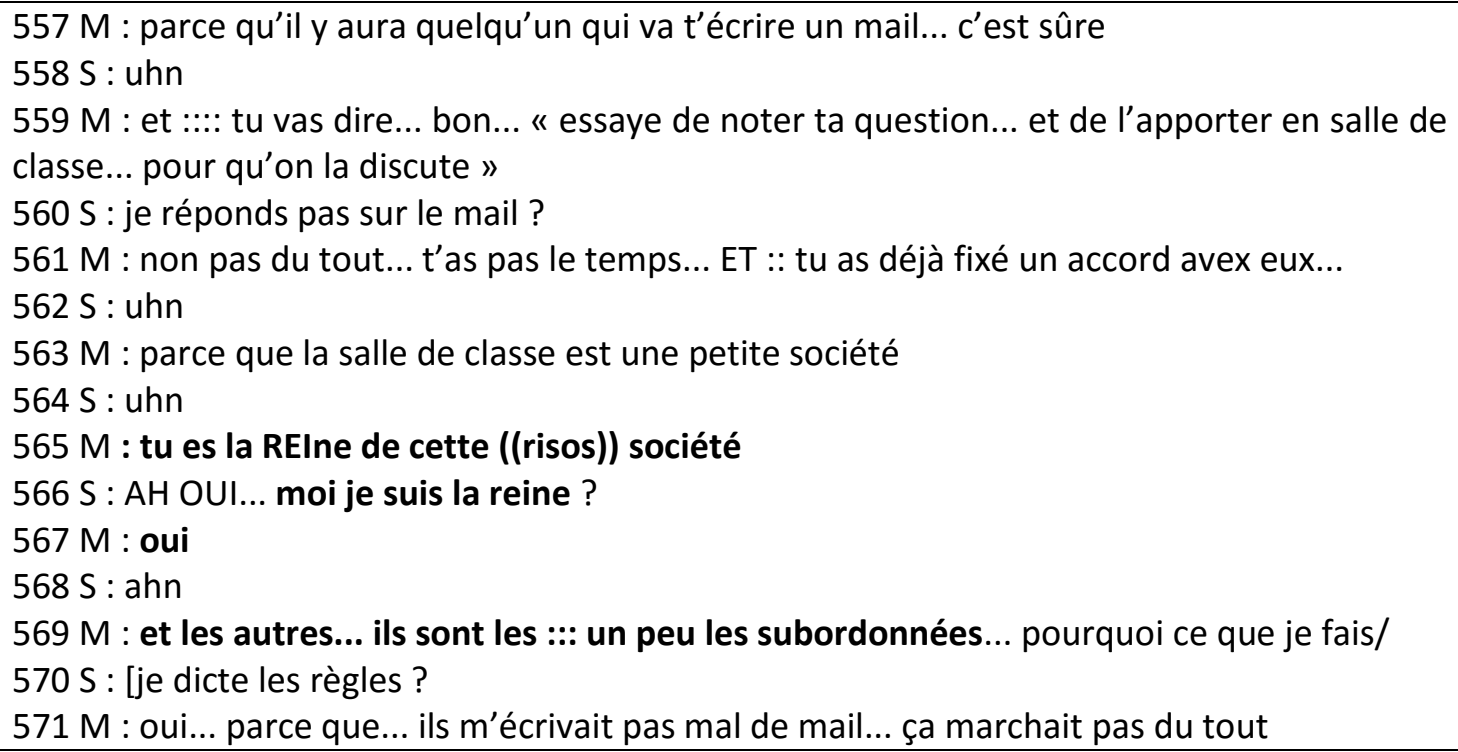

A próxima ocorrência do termo rainha aparece na leitura do comentário de Mariana, assim como nas discussões durante o retorno à primeira IS. Na leitura do comentário, ela aponta o que chamou sua atenção quando se ouviu na gravação e que lhe pareceu um pouco ridículo dizer "eи sou a rainha da pequena sociedade que é a sala de aula". Ela acrescenta que a imagem do professor (no geral) não é a mesma que sua imagem: "o professor não é o rei”, então ela conclui que sua imagem como rainha é algo "pessoal" de sua "personalidade", pois apesar de uma aula de francês precisar de alguém para organizá-la, o professor não é rei, ou seja, não precisa ser autoritário.

201 M. [...] après... quand on parle... que je ne réponds pas les questions des élèves sur le sur le mél parce que j'ai pas le temps... juste après j'explique à Flávia que je ne réponds pas parce que... ça a été un accord déjà fixé avec eux... et je répĖTE que je suis la reine de la petite société qui est la salle de classe... tout ça m'a semblé un peu ridicule... c'est vrai ((risos de Mariana)) qu'un cours de français a besoin de quelqu'un qui organise... les démarches... mais le prof n'est pas du tout le roi... mais ici... je vois quelque chose de personnel et de ma personnalité... qui se reflète dans ma pratique.... NON... ça a été ridiCULE ((risos de Flávia))

Excerto do retorno da primeira instrução ao sósia

A figura da rainha contribuiu para uma imagem que Mariana fez de si mesma ao

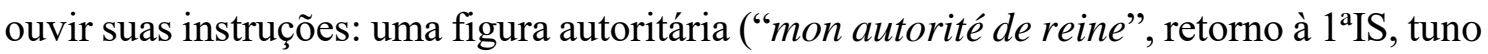


242.M.), o que não lhe agrada. Essa imagem foi construída com ajuda de outras observações sobre suas próprias instruções, como por exemplo: a frase imperativa: "você deve ser autoritária"; sua resposta afirmativa quando a sósia diz "eu sou impositiva nesse momento"; a maneira "autoritária" de agrupar os alunos; o fato de achar estranho os alunos se despedirem com um beijo em seu rosto etc.

199. M. et alors... mon commentaire... « là... ce qui m'a attiré l'attention a été le vocabulaire utilisé par moi... " tu dois être autoritaire " et mon accord avec Flávia quand elle dit « je suis impositive en ce moment "... j'avais jamais pensé à ma façon autoritaire de partager les élèves en les mélangeant pour que les plus forts puissent aider les plus faibles et leur faire interagir... je sais bien qu'il y a d'autres formes de les organiser... avec de petits bouts de papier par exemple... c'est vrai que je ne fais jamais ça... c'est toujours moi qui concentre le pouvoir et je les partage... comme je veux. J'ai pas aimé découvrir ça... entre guillemets découvrir en fait parce que je le savais déjà...((risos de todas)) c'est comme si j'étais la reine et mes élèves, mes sujets... je continue... quand je parle aussi que je trouve bizarre que les élèves me faissent la biSE... ça m'a surpris... à la fin :: on parle de la situation de... de... de la prise de congé...

Excerto do retorno da primeira instrução ao sósia

No entanto, durante as discussões, Mariana começa a se afastar da imagem, antes estabelecida, de rainha autoritária, diante da seguinte pergunta: "você acha que os alunos têm medo da rainha?". Agora, Mariana se vê "apressada" e conclui: "uma rainha jamais estaria atrasada... ela estaria bem vestida... com sapatos de salto alto [...]":

239.F. et tu penses que les élèves... ont peur de la reine ?

240.M. non... pas DU TOUT...

241.F. non ((concordando com a resposta))

242.M: MAIS ils n'ont ils n'ont... ((respira)) ils pouvaient en avoir... mais je pense qu'ils n'en ont pas... parce que je suis... fin... j'arrive un peu pressée... tu vois ? des choses un peu comme ça qui qui... fin... qui retirent un peu de mon autorité de reine... parce qu'une reine serait jaMAIS en retard... elle serait toujours bien habillée... à talon... des choses comme ça... je pense que si j'étais comme ça...

243.S. très rigolote

244. M. oui... oui... ((risos de Fernanda))... je pense que si j'étais comme ÇA... ils en aurons (sic)... de la peur... mais vu que je suis pas comme ça... ils n'en ont pas... ouais

Excerto do retorno da primeira instrução ao sósia

A imagem de Mariana distanciada daquela da rainha autoritária continua no excerto a seguir, em que ela cita um exemplo: mesmo sentindo-se incomodada com uma aluna que sempre faz perguntas, ela dá atenção essa aluna, incentivando-a a fazer a pergunta. Aqui Mariana diz "mesmo se eu quero ser a rainha... eu não sou impositiva". 
quoi... après on avance... après il y a toujours... il y a une dame qui demande touJOURS -- elle commence à me déranger un peu -- ET je dis « oui Lourdes... dis-nous ce que tu veux parler "... « non... non... non... laisse pour après "... « non Lourdes on veut écouter ta question » et on ne veut pas ((diminui o tom de voz)) moi... au moins... je veux pas ((risos de Fernanda)) mais je dois le faire... et donc... oui... même si j'ai... ahn... j'ai vu qu'il y a quelque chose-là... même si je veux être la reine... je suis pas impositive... j'essaye de...fin comment je... j'essaye de les réussir avec de petites stratégies

269.S. uhun ((concordando))

270.M. pour leur plaire

Excerto do retorno da primeira instrução ao sósia

Esses excertos mostram-nos uma grande preocupação que Mariana tem com sua postura diante dos alunos: ser ou não ser autoritária/impositiva? Vemos a autoridade associada a organização do trabalho de Mariana: "é verdade ((risos de Mariana)) que uma aula de francês precisa de alguém que organiza... as etapas..." (retorno à $1^{\mathrm{a}}$ IS, turno 201). Também pode-se associar a autoridade ao controle da situação ensinoaprendizagem, é possível que um aluno que pergunta demais contribua para aula tomar outro rumo, não planejado pelo professor, ele, ainda, pode perder o controle da sala, se deixar os próprios alunos decidirem com quem vão fazer as atividades em grupos; por isso pode ser mais confortável o próprio professor escolher os grupos. É possível que, diante de um professor autoritário (que dificilmente seria cumprimentado com um beijo pelos alunos), os alunos não tenham coragem de fazer tantas questões.

O quadro descrito acima vai ao encontro dos resultados de análises do trabalho de professores iniciantes propostos por Félix e Saujat (2007), pois, para os autores, o centro de preocupações dos professores iniciantes está em estabelecer regras e técnicas de controle da sala de aula, essas preocupações estão ligadas às dificuldades que os iniciantes têm em pôr em prática as atividades didáticas dos alunos. A coanálise do trabalho pelo método da IS e seu retorno, permitiu a Mariana ver outras maneiras possíveis de fazer e/ou ser: "eu jamais tinha pensado na minha maneira autoritária de separar os alunos misturando-os para que os mais fortes possam ajudar os mais fracos, fazendo-os interagir... eu sei bem que há outras formas de organizá-los... com bolinhas de papel por exemplo... é verdade que eu nunca fiz isso... sou sempre eu que controlo o

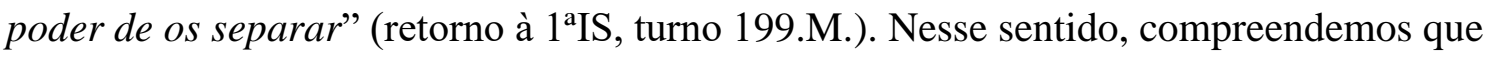
a IS é um método que permite a intervenção na situação de trabalho, fazendo com que a professora tome consciência de algo que não estava claro para si. Dessa forma, ela poderia desenvolver outras maneiras de agir na situação, ou, nos dizeres de Clot (2008), poderia 
desenvolver seu "poder de agir" em relação a maneiras de fazer que a incomodam, pelo fato de reviver a experiência vivida.

Ainda sobre os mecanismos de textualização, examinamos a presença dos pronomes "nous" e “on". O primeiro pronome não foi utilizado pela instrutora, nem pela sósia, em nenhum momento durante a primeira IS. Já o "on" foi usado durante as instruções por Mariana para indicar os grupos de seu contexto de trabalho, esses grupos podem ser representados pela enunciadora em combinação com outras figuras humanas presentes no texto. Além disso, o pronome "on" pode ser também indefinido, quando evoca o professor em geral. Para exemplificar os usos desse pronome, retiramos do texto da primeira IS algumas ocorrências e organizamos em um quadro com significados de "on" em cada turno:

\begin{tabular}{|c|c|}
\hline Os significados do pronome "on" & Exemplos \\
\hline Mariana + professores-monitores & $\begin{array}{l}247 M \text { : elle finit à midi... mais on doit rattraper les } \\
\text { quinze minutes de pause }\end{array}$ \\
\hline Mariana + seus alunos & $\begin{array}{l}221 M \text { : et :: et bon... donc ::: si/s'il y a eu le } \\
\text { devoir... on va le corriger... mais pas tous les } \\
\text { exercices... les plus importants à mon avis }\end{array}$ \\
\hline Os alunos & $\begin{array}{l}365 M:(. . .) \text { au début du semestre... et il y avait } \\
\text { quelques-uns qui ont dit ((intonação diferente)) } \\
\text { " on n'aime pas trop les jeux " }\end{array}$ \\
\hline Pronome indefinido & $\begin{array}{l}209 M: \text { " non "... " répétez... élève } X \text { » et là il } \\
\text { répète... on essaye d'expliquer :.... on essaye de } \\
\text { voir s'il y a... d'autres questions }\end{array}$ \\
\hline
\end{tabular}

Quadro 23: Os significados do pronome on na Primeira IS

A análise da coesão nominal dos textos auxiliou a identificar as representações dos participantes da situação de trabalho de Mariana. Verificamos que a enunciadora faz uma distinção do grupo de professores do seu contexto de trabalho entre: aqueles que são seus colegas mais próximos e aqueles que são menos próximos. Os professores mais próximos são retomados nos textos pelos termos: um prof., seu amigo, alguém, meu amigo, seu amigo prof. etc. Abaixo, temos excertos da IS como exemplo:

$90 \mathrm{M}:(. .$.$) mais si c'est un prof qui est ton ami... peu importe... tu parles..$

$91 \mathrm{~F}:$

[d'accord

$92 \mathrm{M}$ : (...) français... portugais... peu importe... moi... j'essaye toujours de partir avec :: quelqu'un qui est mon ami... pour être plus/plus agréable

Excerto da Primeira Instrução ao Sósia 
$621 \mathrm{M}$ : et à la fin tu vas rencontrer ton ami prof

Excerto da Primeira Instrução ao Sósia

Os outros professores são retomados no texto de forma distanciada do enunciador e do destinatário, como podemos verificar abaixo:

$88 \mathrm{M}: \quad$ [bon... si c'est un prof à qui tu n'es pas trop proche... tu parles en français pour faire/ pour faire un peu l'intello... parce qu'il y a des gens qui aiment ça...

$89 \mathrm{~S}:$ d'accord

Excerto da Primeira Instrução ao Sósia

Em um dos excertos do momento da discussão na IS, Mariana explica que em seu contexto de trabalho há um programa de tutoria, através do qual os professores mais experientes auxiliam os iniciantes. Nessa explicação, podemos verificar os sintagmas nominais utilizados para retomar os participantes que fazem parte deste programa e que, portanto, estão presentes no contexto de trabalho de Mariana. Além disso, destacamos o uso de alguns sintagmas nominais para retomar o programa de tutoria. Abaixo inserimos um excerto do início da explicação desse programa:

$58 \mathrm{M}$ : ALORS... bon... vu que je suis débuTANte... ici on a un programme de tutorat $59 \mathrm{~F}:$ uhn uhn $60 \mathrm{M}$ : comment ça marche... il y a des profs plus expérimentés :: qui seront les tutrices... je parle tutrices parce qu'il n'y a que des filles... et les tuTRIces... elles vont te tutorer... nous... les débutANts....ah :.::: par exemple... moi je suis LÀ... c'est mon premier semestre... MAIS mon :::... mon :: collègue... l'autre tutoré -- parce que on fait le tutorat nous deux :: plus la tutrice... on est trois - mon :::: collègue... l'autre tutoré... c'est son quatrième semestre... regardez ((exclamação)) quatrième semestre ((risos)) il est là... on est là... et ::.:: donc ce tutorat-là c'est le moment pendant la semaine ... on a un rendez-vous pendant la semaine... et là on essaie d'organiser le cours suivant.... MAIS on organise avec des idées mais MOI... enfin... je prends ma feuille... je fais un schéma je partage en colonne... et je le prépare... pour profiter du temps qu'on est là en discutant... Mais par exemple...pour mes autres groupes... que je ne fais pas de tutorat ::.... je prépare moi ::.... chez moi ::..... C'est/ c'est un travail un peu solitaire je dirais... mais ça va parce que... elle met... enfin... elle guide mon travail et elle marche aussi comme une mémoire... parce que le semestre prochain... je ne vais pas me rappeler tout ce que j'ai travaillé... donc c'est enregistré... mais c'est à moi ce registre-là... c'est pas personne

Excerto da Discussão da Primeira Instrução ao Sósia

Ao descrever o programa de tutoria, Mariana indica a existência de dois grupos: o grupo de professoras tutoras, que são mais experientes no ensino de FLE e o grupo de 
professores iniciantes chamados "tutorés", que participam da tutoria. Apresentamos na tabela abaixo os termos que Mariana utiliza para retomar os participantes (inclusive a própria enunciadora) dos dois grupos existentes neste programa:

\begin{tabular}{|l|l|}
\hline Os participantes da tutoria & Retomada dos participantes \\
\hline As tutoras & $\begin{array}{l}\text { des profs plus expérimentés/ une prof plus } \\
\text { expérimentée }\end{array}$ \\
& les tutrices \\
elles/elle \\
\hline Os "tutorés" & nous \\
& les débutants \\
& moi / je \\
une tutorée \\
mon collègue \\
l'autre tutoré \\
il \\
\hline
\end{tabular}

Quadro 24: Os participantes da situação de trabalho de Mariana

Mariana está inserida no segundo grupo, dos “tutorés", ou seja, dos professoresmonitores iniciantes. É interessante observar o uso de "mon collègue" para se referir a um "tutoré", o que pode indicar uma aproximação maior com o grupo em que ela está inserida do que com o grupo das tutoras.

O programa de tutoria é retomado pelos seguintes sintagmas nominais:

\begin{tabular}{|l|l|}
\hline O programa de tutoria & un programme de tutorat \\
& $\begin{array}{l}\text { le tutorat } \\
\text { un rendez-vous } \\
\text { une réunion informelle }\end{array}$ \\
\hline
\end{tabular}

Quadro 25: O programa de tutoria retomado na IS

Ao utilizar o termo "uma reunião informal" para indicar o programa de tutoria, Mariana, provavelmente, está tentando diferenciar a reunião de tutoria da reunião mensal com a coordenadora e os monitores dos cursos Extracurriculares de francês, indicada no Guide du Moniteur. Não há informações nesse documento de orientação sobre as reuniões de tutoria, no entanto, de acordo com as explicações de Mariana, elas são encontros semanais, em que há três pessoas, todos são professores do mesmo contexto, sendo que uma é a tutora, professora mais experiente, e dois são os "tutorés", monitores iniciantes. Mariana diz que a professora tutora auxilia os outros dois professores iniciantes a organizar as aulas, a guiar o trabalho e dar ideias. 
Além da referência dos participantes do contexto de trabalho, a enunciadora faz referência a outras figuras humanas no texto, como por exemplo, aos alunos com o uso do pronome eles (ils) e os termos: um grupo, todo mundo, aluno, (un groupe, tout le monde, élève) como nos excertos a seguir:

$131 \mathrm{M}$ : parce que comme ça aussi tu brises la glace... parce que vu qu'ils se voient une fois par semaine... ils ne se connaissent pas trop... et c'est un groupe vraiment hétérogène donc... ils commencent à papoter un peu... ça... ça devient plus sympa... quoi

Excerto da Primeira Instrução ao Sósia

$207 \mathrm{M}$ : je peux arrêter tout le monde et « attention... écoutez... est-ce que vous avez écouté la question de l'élève/ de l'élève $X$ ?"

Excerto da Primeira Instrução ao Sósia

Além da identificação das retomadas das figuras humanas, buscamos analisar como Mariana se refere ao seu trabalho. Com isso, pretendemos compreender o trabalho do professor iniciante. Assim, encontramos o seguinte excerto:

$201 \mathrm{M}$ : mais... c'est vrai que là... je suis un peu plus habituée mais avant... enfin... quand j'étais/ quand j'ai vraiment commencé à faire cours... je notais tout... exactement...

Excerto da Primeira Instrução ao Sósia

Notamos que Mariana escolhe o termo "faire cours" para indicar seu métier de professora. O significado dessa expressão, de acordo com o dicionário virtual Larousse ${ }^{61}$ é: "enseigner sa matière, en parlant d'un professeur" "2 . Mariana poderia ter usado outros termos para substituir o termo destacado como, por exemplo: "quando eu realmente comecei" a trabalhar, a ensinar etc. No entanto, Mariana opta por "faire cours", que pode ser traduzido em português como "dar aulas". Essa escolha mostra como a enunciadora vê sua atividade de trabalho, neste caso, a palavra aula (cours) recebe destaque. Com isso, é possível pensar que dentre todas as atividades desenvolvidas por Mariana em seu trabalho, sua preocupação maior é com a aula.

Aqui cabe a observação de que Mariana, ao falar sobre seu métier, compara sua atuação passada com a presente. Isso pode revelar uma reflexão sobre seu trabalho, pois

\footnotetext{
${ }^{61} \mathrm{http}: / / \mathrm{www}$. larousse.fr/dictionnaires/francais/cours/19939/locution?q=faire+cours\#154243 consultado em 21/10/2014.

62 ensinar sua matéria, tratando-se de um professor (tradução nossa).
} 
a IS permite que Mariana reviva sua experiência para poder viver outras experiências, como aponta Clot (2001).

\subsubsection{Mecanismos enunciativos}

Sobre os mecanismos enunciativos, encontramos modalizações apreciativas de cunho positivo, ligadas às opiniões do enunciador ou dos alunos. Apresentamos abaixo um exemplo de uma apreciação positiva do enunciador:

250 S : à quel moment on fait la pause ? je vais dire/ je vais choisir le moment de la pause ?
$251 \mathrm{M}$ : oui... moi ce que j'aime bien c'est... le cours commence à 9 heures... j'aim/ i'aime bien faire la
pause onze heures moins le quart

Excerto da Primeira Instrução ao Sósia

A modalização apreciativa do exemplo é utilizada pela enunciadora para se referir ao horário exato em que ela gosta de fazer o intervalo da aula. Esta apreciação positiva sugere como Mariana prefere organizar seu trabalho, deixando-o mais agradável.

Outra modalização apreciativa positiva aparece no excerto em que Mariana explica sobre o uso de uma ficha preparada antes de sua aula. Essa ficha tem função de auxiliar seu trabalho em sala, principalmente, no caso de acontecer algum um imprevisto e a aula sair do que estava planejado. Com o uso da ficha é possível retomar o que é preciso ser feito:

$191 \mathrm{M}$ : parce qu'elle est bien parce que même si tu leur parles quelque chose rien à voir avec le cours... par exemple ::: je sais pas si/ s'il y a une nouvelle passée... quelque chose comme une catastrophe et tout le monde est en train d'en parler... $192 \mathrm{~S}$ : uhun $193 \mathrm{M}: \mathrm{tu} / \mathrm{tu} / \mathrm{tu}$ te remets à ce que tu dois faire en regardant la fiche

Excerto da primeira Instrução ao Sósia

A ficha é preparada pela professora para indicar o que precisa ser feito em sala de aula. Assim, entendemos que a ficha utilizada por Mariana é o que Amigues (2009) chama por "re-conception", é a transformação da prescrição, existente no contexto de trabalho, para que ela seja apropriada conforme os recursos disponíveis, para seu contexto de trabalho.

Vemos uma avaliação positiva de Mariana sobre o uso de uma ficha que é a reelaboração da atividade que deve ser feita. Isso mostra que a ficha traz um conforto para seu trabalho, ela não deixa a professora se perder, mesmo com um imprevisto. 
Imaginamos que se Mariana utilizasse apenas as prescrições já existentes para desenvolver sua atividade, como por exemplo, o manual de orientação do material didático, não seria suficiente para trazer este conforto em seu trabalho.

A análise das modalizações deônticas, mostrou-nos uma forte presença das modalizações que representam o domínio do direito, da obrigação social. Elas se apresentam com o emprego dos verbos dever e poder no presente do indicativo. Encontramos estas modalizações também associadas ao conteúdo temático sobre o intervalo de aula, destacando a importância do intervalo para o trabalho de Mariana:

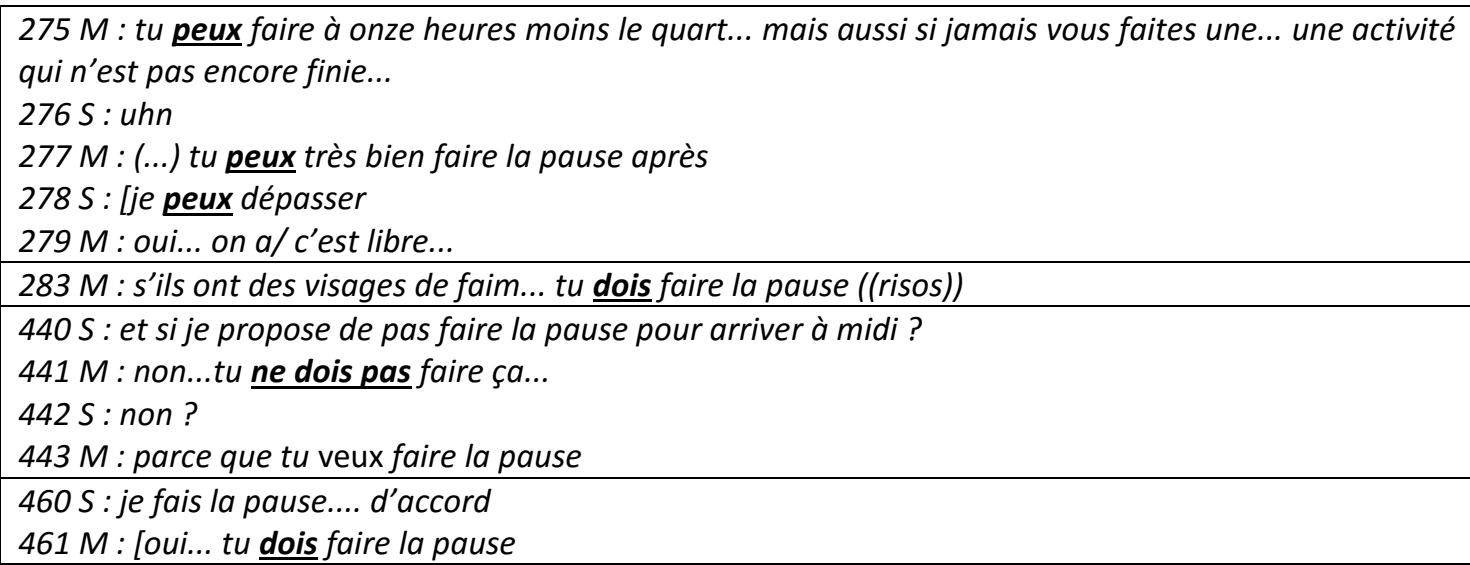

Excertos da Primeira Instrução ao Sósia

Nos excertos acima, observamos que as modalizações destacam a importância do intervalo (pause) para Mariana. No primeiro excerto, a enunciadora indica à sósia quando pode ser feito o intervalo, explicando que a escolha do horário é livre. Em seguida, há a instrução do intervalo ser feito de acordo com a fisionomia dos alunos (fome, cansaço). Por fim, a sósia pergunta se é possível não fazer o intervalo; para responder que isso não é possível, Mariana usa uma modalização apreciativa: "você quer fazer o intervalo" e uma modalização deôntica: "você deve fazer o intervalo".

Também estão presentes no texto modalizações lógicas que nos auxiliaram a identificar algumas das opiniões de Mariana, como as destacadas abaixo:

$221 \mathrm{M}$ : et :: et bon... donc ::: si/s'il y a eu le devoir... on va le corriger... mais pas tous les exercices... les plus importants à mon avis

$229 \mathrm{M}$ : (...) et vu que vous avez les corrigés... vous allez confirmer... avec vos corrigés et si jamais vous avez des questions... vous me les posez la semaine prochaine " mais je ne sais pas s'ils le font... je

pense que non... eh ::

Excertos da Primeira Instrução ao Sósia 
O uso das modalizações lógicas mostra o julgamento que a enunciadora faz sobre o conteúdo abordado. Os dois excertos abordam a questão da tarefa (devoir) e correção de tarefa. Mariana instrui a sósia a corrigir a tarefa, mas não todos os exercícios de tarefa, somente os que ela acha mais importantes. A enunciadora também expõe sua opinião: ela acha que seus alunos não fazem a tarefa.

Ainda analisando os mecanismos enunciativos, constatamos a presença de algumas vozes nos textos. Primeiramente, encontramos as vozes da professora enunciadora do texto - e de seus alunos. O recurso utilizado para apresentação das vozes é o discurso direto:

$105 \mathrm{M}:$ (...) il y a un monsieur qui est pasteur de l'église donc... il est là/

$106 \mathrm{~S}:$ : [ah... il sera surement à l'heure

$107 \mathrm{M}$ : oui... il va me dire « bonjour Mariana... comment allez-vous ? » et je vais dire " oui ca va nickel

et vous? "; " qu'est-ce que c'est nickel ? " ((risos)) eh ::

Excerto da Primeira Instrução ao Sósia

Ainda encontramos a voz da didática das línguas, representada pelo jargão profissional do professor de língua estrangeira (Authier-Revuz, 1998). Esta voz aparece quando Mariana explica sobre a produção da ficha preparada antes da aula. Em sua ficha, ela anota as habilidades que precisam ser desenvolvidas em LE (compreensão oral e escrita e produção oral e escrita), que podem ser encontradas no documento com orientações sobre ensino e aprendizagem de línguas: o CECR:

155 M : NON... pardon pardon... le type d'habi/ habileté... compréhension orale... production orale... compréhension écrite... production écrite

Excerto da Primeira Instrução ao Sósia

Deparamo-nos, ainda, com a voz dos professores do contexto de trabalho da enunciadora, introduzida pelo verbo dire seguido do discurso direto:

$48 \mathrm{M}$ : oui... oui... donc tu seras animée... c'est sûr qu'il y aura quelqu'un qui va te dire ((mudou o tom da voz)) "non, mais tu es trop animée, regarde, c'est samedi matin. "

Excerto da Primeira Instrução ao Sósia

Neste caso, a voz dos professores aparece para reprovar uma atitude de Mariana: estar muito animada em um sábado de manhã.

A seguir destacamos outro exemplo de voz da equipe de professores: 
288. M. et ::: après... quand j'ai écouté l'Instruction au Sosie... je me me suis rendue compte que ça existe... c'est un peu dommage mais ça existe quand même... " non... on parle français... on est du français ...on parle français... je veux voir ton niveau de langue parce que tu as habité en France "... ça j'ai senti juste après

289. S. ah oui ?

290. M. mon arrivée... mon retour ((hesita procurando o melhor termo))

291. S. ton retour de France

292. M. mon retour de... ma rentrée ... j'ai senti... il y avait pas mal de gens qui voulaient me parler en franÇAIS pour voir mon... nouveau niveau... disons

293. S. ah bon?

294. M. et j'ai dit " non... j'ai... j'ai marre de parler en français...parce que j'ai parlé HUIT MOIS en parlant français " et les personnes ((faz voz diferente da habitual)) " non mais on continue "... et c'était PAS pour me faire plaisir

295. S. ouais ((concordando))

296. M. C'était pour VOIR... et donc... ça c'est pas bien... parmi une équipe de profs... un collègue va essayer de vérifier l'autre ? Ça c'est pas bien... et ça me dérange... je savais un peu... mais après I'Instruction au Sosie ça m'a dérangé PLUS

\section{Excerto do retorno da Primeira IS}

Identificamos a voz dos professores do contexto de trabalho estudado exposta para mostrar a existência da prática de alguns desses professores de avaliar o nível de língua dos próprios colegas de trabalho. Na situação relatada, a enunciadora diz que após ter voltado da França, onde ficou por oito meses, sentiu uma insistência de alguns professores em conversarem em francês para verificar seu nível de francês, atitude esta, que lhe incomoda.

\subsubsection{Figuras de ação}

A análise das figuras de ação permitiu observar o posicionamento da professora, enunciadora da IS, diante do trabalho a ser realizado, servindo como base para compreender as representações sobre o seu trabalho. Verificamos que predomina no texto da primeira IS a ação experiência, marcada pelo discurso interativo, e em alguns casos, por advérbio de tempo (toujours) e organizadores temporais (après, donc).

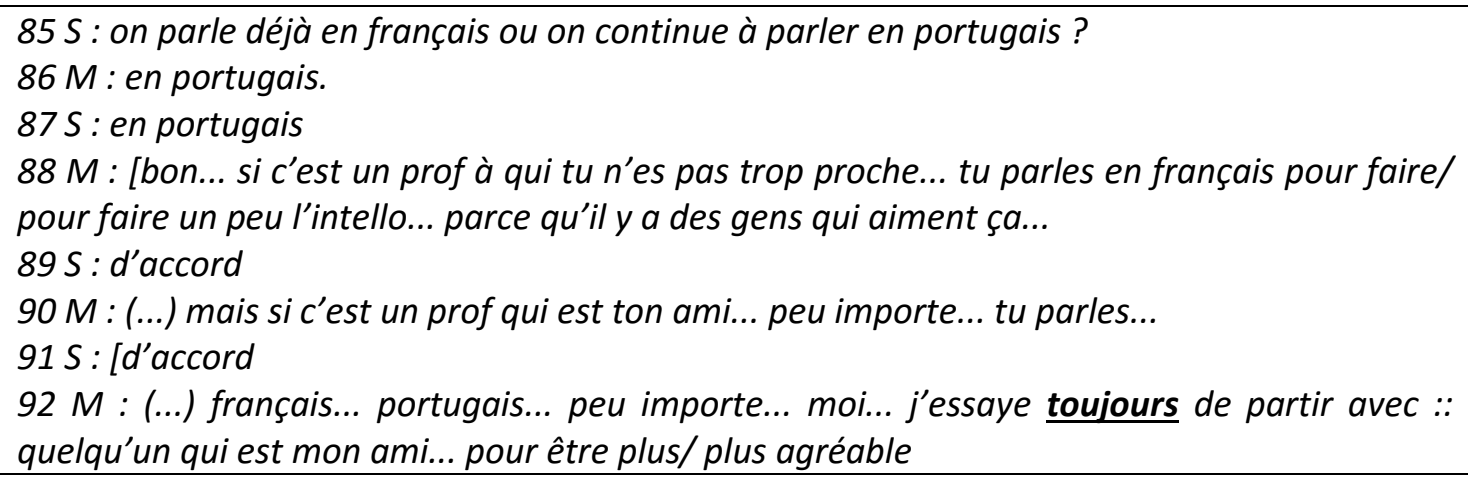

Excerto da Primeira Instrução ao Sósia 
Segundo Bulea (2010), a figura de ação experiência retrata a cristalização pessoal de acontecimentos, ou seja, vemos a experiência do professor pela repetição de uma mesma tarefa. No excerto acima, Mariana explica que tenta ir sempre, no trajeto da sala dos monitores à sala de aula, acompanhada por um professor que é seu amigo, pois acha mais agradável a situação. Ao longo da primeira IS, a figura de ação experiência é formada por conteúdos temáticos semelhantes ao do excerto acima, que não estão ligados diretamente ao ensino, mas à organização do ambiente de trabalho, para que ele seja prático e/ou agradável. Isso pode ser uma característica do professor iniciante, já que, como dissemos, para Saujat (2004b), o professor que é iniciante busca compensar as dificuldades provisórias para resolver os problemas com recursos intermediários, como por exemplo, técnicas de controle da sala de aula. Isso porque o professor preocupa-se com um ambiente em que seja possível a aprendizagem dos alunos, mas também sua própria aprendizagem.

A figura de ação ocorrência, caracterizada por um forte grau de contextualização, tem seu agir-referente ligado à sua textualização (Bulea, 2010). Assim, apresenta-se principalmente em segmentos do discurso interativo, com o actante implicado, representado por pronomes pessoais de primeira pessoa. Para compreender o trabalho de Mariana, buscamos essa figura de ação, principalmente nos excertos em que ela contextualiza seu ambiente de trabalho. Para exemplificar esta figura de ação, destacamos o segmento abaixo, em que Mariana contextualiza a sala de aula com informações sobre os seus alunos, ou seja, os participantes envolvidos em situação de trabalho. Mariana explica à sósia que a maioria dos alunos aguarda por sua chegada na sala de aula, sobretudo um senhor que é pastor:

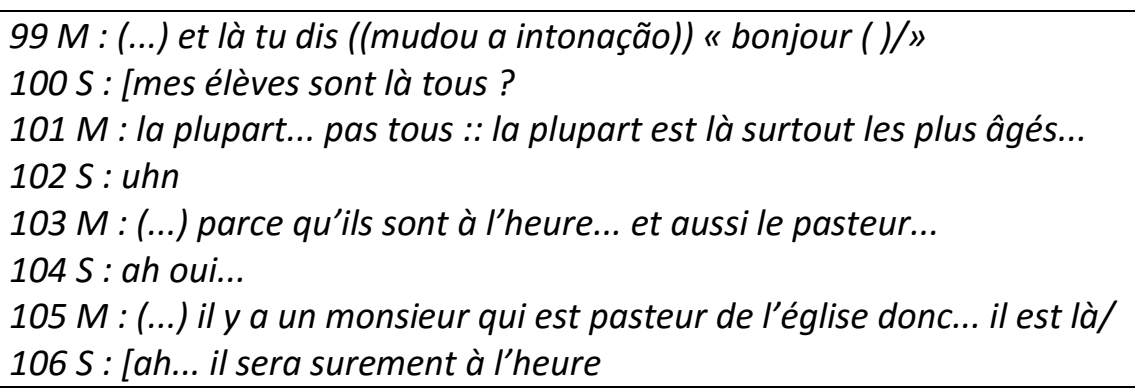

Excerto da Primeira Instrução ao Sósia

Destacamos também, a presença da figura de ação canônica, que expõe a regra, a prescrição determinada por uma instância normativa exterior ao actante (BULEA, 2010). 
Apresentamos um excerto em que essa figura aparece quando Mariana esclarece à sósia como deve ser explicada uma regra de pronúncia ("plus" ou "pluS") em frases comparativas. Por se tratar de um conteúdo linguístico, essa regra vem de uma instância normativa exterior ao actante (Mariana) e a seu ambiente de trabalho:

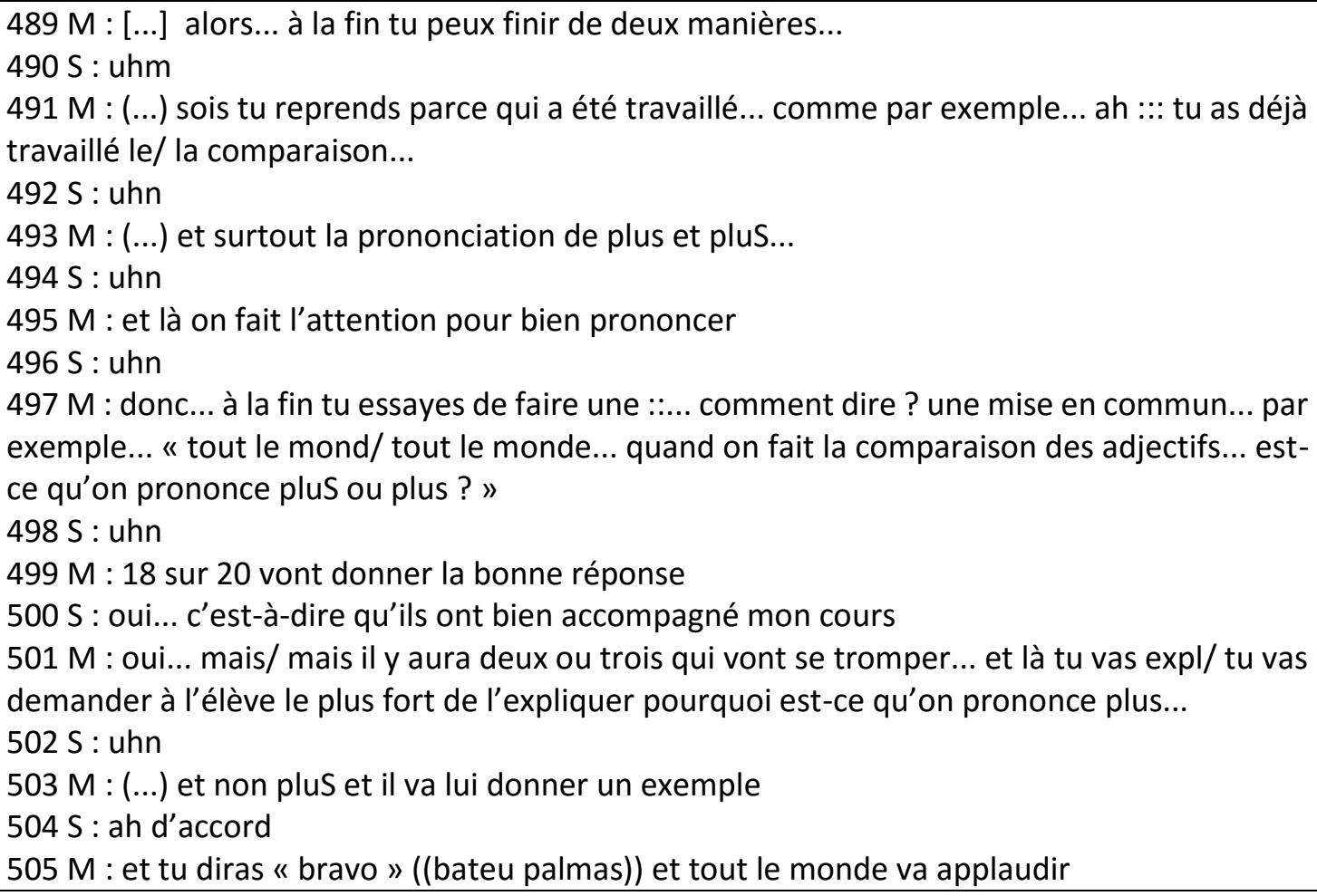

A figura de ação acontecimento passado "propõe uma apreensão retrospectiva do agir" (BULEA, 2009, p.144). Essa figura foi encontrada nos excertos em que a enunciadora se posiciona no passado para comparar o início da sua atividade profissional com o momento atual da carreira profissional. Para isso, ela desloca o eixo temporal para um momento preciso no passado, como destacado abaixo:

$171 \mathrm{M}:$ (...) parce qu'avant/avant d'apprendre à faire cette fiche... je faisais des brouillons... $172 \mathrm{~S}:$ uhn

$173 \mathrm{M}:(. .$.$) pour organiser un peu ce que j'allais travailler...$

Excerto da Primeira Instrução ao Sósia

$74 M$ : parce que/ une chose qui/ une chose importante que la fiche m'a apporté :: c'est de minuter parce que... avant quand je ne minutais pas j'étais anxieuse... grâce/ à cause de deux problèmes soit mon cours finirait avant...

$75 F$ : uhn 
76M : quelque chose comme demie heure avant... et je ne savais pas du tout quoi faire $(($ rindo))... soit j'aurais trop de travail... ils seront débordés et :.:.: je ferais pas tout ce qu'était prévu... donc minuter - c'est vrai que je n'arrive pas faire exactement le minute prévu - c'est vrais que minuter... ça me donne une idée :: de combien de minutes je vais dépenser

Excerto da Primeira Instrução ao Sósia - Discussão

Nos dois excertos, a enunciadora recorre ao passado para retomar o início de sua carreira, quando não utilizava uma ficha, que é preparada por ela para organizar seu trabalho. Essa ficha é vista como uma aprendizagem que se deu com base em suas experiências do passado ("antes de aprender a fazer essa ficha [...]"). O trabalho de Mariana passa a ser mais organizado para ela mesma, dessa forma, ao lado de Saujat (2004b), vemos a preocupação de um professor iniciante em organizar seu contexto de trabalho, para que ele seja um ambiente possível para a aprendizagem dos alunos, mas também para sua própria aprendizagem.

\subsection{Segunda Instrução ao Sósia}

A seguir apresentamos os resultados da análise dos textos de segunda Instrução ao Sósia (instruções de Mariana e discussão) e retorno à segunda IS. Além disso, em alguns casos, julgamos interessante apresentarmos uma comparação dos resultados desta análise com os dos textos da primeira IS.

\subsubsection{Contextos}

Referente ao contexto físico, os textos gerados da segunda entrevista de Instrução ao sósia e de seu retorno foram produzidos pelas mesmas participantes da primeira IS por mim, Mariana e Flávia, sendo assim, eles têm os mesmos emissores e receptores. Todos esses textos, como já explicamos, foram produzidos em diferentes salas dos prédios da FFLCH na USP, sendo que a segunda IS tem como lugar de produção, mais precisamente, uma sala do prédio do curso de Letras, no dia 27 de novembro de 2013, por volta das 19 horas. Já o retorno à segunda IS deu-se em uma das salas do prédio de Filosofia, pois não encontramos nenhuma sala disponível no prédio de Letras. O retorno aconteceu quase cinco meses depois da IS, em 24 de abril de 2014, isso porque, como parte deste período corresponde às férias escolares, não havíamos mais aulas toda a semana, o que dificultou a escolha de um dia em que fosse possível nosso encontro. 
O tempo de produção da IS foi de 1 hora, 18 minutos e 52 segundos, sendo que as primeiras instruções foram de Mariana que começaram em 01 minuto e 39 segundos e terminaram em 31 minutos e 32 segundos de entrevista. As discussões tiveram início após 01 hora, 01 minuto e 11 segundos de entrevista. No que diz respeito ao retorno à segunda IS, seu tempo total foi de 34 minutos e 59 segundos, divididos entre leitura dos comentários de Mariana com breves reflexões (que durou por volta de 12 minutos), leitura dos meus comentários, também com breve reflexão (por volta de 05 minutos), e discussão sobre os nossos comentários.

O contexto sociossubjetivo da segunda IS e seu retorno já foi explicado anteriormente na parte em que aborda a primeira IS e seu retorno, visto que o lugar social, os objetivos e a posição social do emissor e destinatário são os mesmos nos textos de IS e retornos. No entanto, é preciso dizer que há uma diferença no contexto de produção da primeira IS com a segunda IS. Antes da produção da segunda IS, decidimos instruir a sósia a explicar as atividades de francês que seriam trabalhadas na aula da substituição hipotética. Isso diferenciou significativamente os conteúdos temáticos abordados nas duas etapas de instruções ao sósia: na primeira IS, eles são mais voltados ao contexto geral de trabalho, já na segunda IS, às atividades desenvolvidas em sala de aula com os alunos.

\subsubsection{Infraestrutura geral}

Apresentamos a seguir o plano global dos conteúdos temáticos da segunda IS e de seu retorno, assim como o enunciador e o turno que correspondente ao tema abordado:

Plano Global dos Conteúdos Temáticos da Segunda Instrução ao Sósia

\begin{tabular}{|l|l|l|}
\hline \multicolumn{1}{|c|}{ Temas } & Enunciador & Turno \\
\hline Explicação sobre o assunto que será abordado na entrevista & Sósia & $3 . S$ \\
\hline Escolha de quem iniciará a entrevista & Sósia & $17 . S$ \\
\hline Situação hipotética de substituição no contexto de trabalho de Mariana & Sósia & $23 . S$ \\
\hline Contextualização do curso (turma, livro, conteúdo) & Mariana & $36 . \mathrm{M}$ \\
\hline Maneira de começar a aula & Sósia & $43 . S$ \\
\hline $\begin{array}{l}\text { correção dos exercícios (como corrigir os erros, revisão, quais exercícios } \\
\text { corrigir) }\end{array}$ & Mariana & $56 . \mathrm{M}$ \\
\hline Maneira de passar de uma atividade para outra & Sósia & $221 . S$ \\
\hline uso da lousa & Sósia & $235 . S$ \\
\hline Procedimentos utilizados para leitura e interpretação de texto & Mariana & $260 . M$ \\
\hline
\end{tabular}




\begin{tabular}{|l|l|l|}
\hline Atividade de verdadeiro/falso (como fazer e como corrigir) & Mariana & $330 . \mathrm{M}$ \\
\hline Mudança de uma atividade para outra & Sósia & $375 . S$ \\
\hline Explicação gramatical (superlativo) & Mariana & $396 . \mathrm{M}$ \\
\hline
\end{tabular}

Quadro 26: Síntese do Plano Global dos Conteúdos Temáticos da $2^{\mathrm{a}}$ Instrução ao Sósia

\section{Discussão da segunda Instrução ao Sósia}

\begin{tabular}{|l|l|l|}
\hline \multicolumn{1}{|c|}{ Temas } & Enunciador & Turno \\
\hline Introdução da discussão & Sósia & $1 . S$ \\
\hline uso exclusivo do livro didático & Fernanda & $5 . F$ \\
\hline Pronome de tratamento usado com os alunos & Mariana & $105 . M$ \\
\hline uso da língua portuguesa em aula de FLE & Mariana & $171 . \mathrm{M}$ \\
\hline $\begin{array}{l}\text { Finalização da discussão e explicação sobre o próximo passo antes da } \\
\text { reunião do retorno à instrução ao sósia }\end{array}$ & Sósia & 223.5 \\
\hline
\end{tabular}

Quadro 27: Síntese do Plano Global dos Conteúdos Temáticos da Discussão da $2^{\text {a }}$ Instrução ao Sósia

\section{Retorno à primeira Instrução ao Sósia}

\begin{tabular}{|c|c|c|}
\hline Temas & Enunciador & Turno \\
\hline Explicação de como será o retorno & Sósia & 5.5 \\
\hline $\begin{array}{l}\text { Leitura do texto comentário (a correção dos exercícios de tarefa, sobre o } \\
\text { modo de passar as instruções ao Sósia (o uso de je e tu), o uso da lousa, } \\
\text { a utilização exclusiva do livro didático, pronome de tratamento usado } \\
\text { com os alunos, as diferentes escolhas de um professor para outro) }\end{array}$ & Mariana & 30.M \\
\hline Reflexão sobre a correção dos exercícios de tarefa & Sósia & 35.5 \\
\hline Preparação das explicações de exercícios & Fernanda & $95 . \mathrm{F}$ \\
\hline Experiência real de substituição de aula & Mariana & 129.M \\
\hline $\begin{array}{l}\text { Reflexão sobre a diferença entre as instruções dadas a um professor que } \\
\text { substituirá e ao sósia }\end{array}$ & Fernanda & 139.F \\
\hline Objetivo da instrução ao sósia & Sósia & $153 . S$ \\
\hline Mudança de um tema para outro na sala de aula & Mariana & 208.M \\
\hline Discussão sobre avaliações orais & Mariana & 219.M \\
\hline
\end{tabular}

Quadro 28: Síntese do Plano Global dos Conteúdos Temáticos do Retorno à $2^{\text {a }}$ Instrução ao Sósia

Como nos primeiros textos de IS, o tipo de discurso predominante nos textos gerados nesta segunda etapa é o discurso interativo, pois os interlocutores estão implicados no ato da produção dos textos em um espaço/tempo comum. Os interlocutores são caracterizados por marcas de referência (je, tu, on e nous) e suas formas verbais.

Como já dissemos, a enunciadora do texto da IS deve fazer o uso do pronome $t u$ para instruir a sósia, técnica que permite um distanciamento de sua própria atividade, para vê-la com os olhos de outro. Fizemos um levantamento do uso de tu e je na primeira IS, com o intuito de verificar qual dos pronomes predomina nas instruções. Neste momento, podemos comparar o levantamento dos pronomes utilizados nas duas IS: 


\begin{tabular}{|c|c|c|c|c|}
\cline { 2 - 5 } \multicolumn{1}{c|}{} & \multicolumn{2}{c|}{ Primeira Instrução ao Sósia } & \multicolumn{2}{c|}{ Segunda Instrução ao Sósia } \\
\cline { 2 - 5 } \multicolumn{1}{c|}{} & Je & Tu & Je & Tu \\
\hline Mariana & 66 & 217 & 38 & 231 \\
\hline Sósia & 128 & 03 & 114 & 06 \\
\hline Total & 194 & 220 & 152 & 237 \\
\hline \multicolumn{2}{|c}{ Quadro 29: os pronomes "je" e "tu" utilizados nas duas Instruções ao Sósia } \\
\multicolumn{2}{|c}{}
\end{tabular}

Apesar da ocorrência maior do pronome tu na segunda IS, conferimos que a enunciadora usou majoritariamente o $t u$ nas duas IS, o que indica que a técnica de instrução ao sósia foi aplicada como proposto pela Clínica da Atividade, já que, a partir de uma substituição hipotética, o professor/instrutor deve dizer ao seu sósia tudo o que é preciso ser feito em seu contexto de trabalho, para que ninguém perceba a substituição. Para tanto, é necessário que as instruções sejam dirigidas ao sósia com a utilização do pronome $t u$. O uso de $t u$ permite que o enunciador tenha um certo distanciamento de sua própria atividade, dessa maneira, o professor/instrutor pode ver sua atividade com os "olhos de outro" (CLOT, 2001; SAUJAT, 2015). Por sua vez, a sósia usa predominantemente o je para que a professora-instrutora não se esqueça, durante as instruções, da situação hipotética de substituição.

Nos resultados da análise da primeira IS, destacamos o uso de je ligado aos momentos em que Mariana interrompe as instruções para explicar ou exemplificar o que ela faz ou fez em sala de aula, aproximando-se da situação de trabalho. Na segunda IS, a ocorrência do pronome je está mais associada ao professor e aos alunos (em discurso direto) em situação de ensino-aprendizagem. Além disso, há a presença do je, sem estar vinculado a uma pessoa determinada, isso ocorre em explicações do conteúdo, exemplos, questões e respostas de exercícios:

72. $\mathrm{M}$ :

à propos des questions versées

[c'est six exercices pas très simples... c'est

73. $S$ : uhum

74. M: [et::: des pronoms indéfinis des adverbes... un peu comme::... "tu vas quelque part? non:: je ne vais nulle part... tu as connu quelqu'un? non:: je n'ai connu perso::nne"

75. S: uhum

76. M: alors tu vas corriger::

Excerto da Segunda Instrução ao Sósia 
176. M: parce que... ahn:: Ma/éh:: "Mariana tu vas pas (sic) corriger le:: l'exercice b?" tu dis "non désolée on n'a pas le temps si vous voulez je l'envoie::... je vous envoie par mèl les corrigés"

177. $S$ :

[uhum

178. $\mathrm{M}$ :

[( ) MAIS...

si la personne dit "vraiment j'ai une question très ponctuelle je voudrais que tu fasses cet exercice"... là tu dis:: "bon allez vite fait ((palma))" et tu le fait au tableau

179. S : d'accord

\section{Excerto da Segunda Instrução ao Sósia}

Estas ocorrências são mais frequentes na segunda instrução ao sósia ao compararmos com a primeira, acreditamos que este fato está associado aos temas abordados nas IS, pois diferentemente da primeira, na segunda IS, o enunciador tem como foco dar as instruções sobre o conteúdo e as atividades a serem trabalhadas na aula do dia seguinte. Portanto, o enunciador, usando o discurso direto, coloca-se em situação de trabalho para explicar o conteúdo para seus alunos, que, por sua vez, respondem o que foi solicitado pelo professor.

Assim como na primeira, na segunda IS há excertos em relato interativo. Vimos que na primeira IS Mariana se distancia da ação de linguagem para comparar o que ela fazia no início da carreira com o que ela faz atualmente. Na segunda IS, a enunciadora também se distancia do mundo discursivo da ação de linguagem para fazer uma comparação, mas desta vez, ela compara a aprendizagem de seus alunos com sua própria aprendizagem quando era aluna de francês:

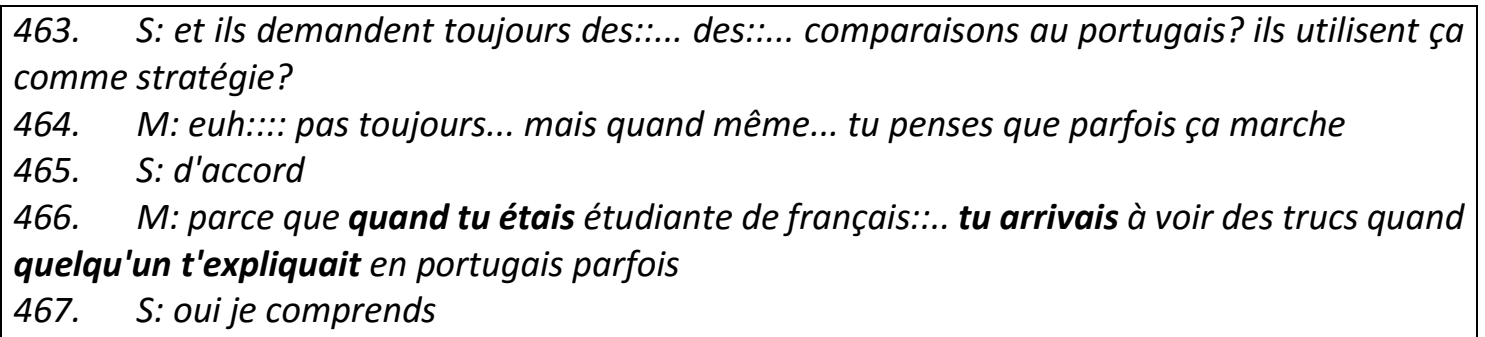

Excerto da Segunda Instrução ao Sósia

Mariana instrui a sósia a fazer comparações do francês com o português, se isso for solicitado por algum aluno, em seguida, a sósia pergunta se os alunos sempre solicitam este recurso. Mariana indica que isso não acontece sempre e, utilizando-se de um organizador temporal (quando) seguido de verbos no imperfeito (era, conseguia), demonstra usar como estratégia a comparação com a língua materna, por ser algo que facilitava sua compreensão quando ela era aluna. 
Como já dissemos, os textos analisados (as IS e os retornos) são organizados em sequências dialogais que se estruturam em turnos assumidos pelos interlocutores na interação verbal. Nos textos de IS, analisamos apenas as instruções de Mariana, assim os turnos são alternados entre Mariana e a sósia, já nas discussões e nos textos do retorno, os turnos são tomados por três interlocutores (Mariana, Fernanda e a sósia). No quadro abaixo indicamos a quantidade total de turnos dos textos analisados e a quantidade de turnos de cada uma das participantes em cada texto:

\begin{tabular}{|c|c|c|c|c|}
\hline $\begin{array}{c}\text { 2a IS e } \\
\text { Retorno à 2a IS }\end{array}$ & Mariana & Sósia & Fernanda & Total de turnos \\
\hline $\begin{array}{c}\text { Instruções de } \\
\text { Mariana }\end{array}$ & 232 turnos & 232 turnos & -- & 464 turnos \\
\hline Discussão & 100 turnos & 37 turnos & 96 turnos & 233 turnos \\
\hline Retorno à 2a IS & 129 turnos & 123 turnos & 89 turnos & 341 turnos \\
\hline
\end{tabular}

Quadro 30: Quantidade de turnos na $2^{\mathrm{a}}$ IS e no Retorno da $2^{\mathrm{a}} \mathrm{IS}$

Como acontece na primeira IS, os turnos da sósia são menores, pois seu objetivo é pedir explicações, explicitações à instrutora, já os turnos da instrutora são mais longos, por explicar com detalhes o que a sósia deve fazer para substituí-la. Além disso, muitos dos turnos da sósia têm como função concordar com a instrutora: "uhun", "ahan", “d'accord” etc. Os turnos dos textos em que há um debate, são divididos entre mim, Mariana e Flávia sendo que a quantidade de turnos pode variar.

Também nos atentamos às hesitações, explicadas como pausas não-sintáticas por Marcuschi (2001) presentes na segunda IS. Retiramos um excerto em que Mariana inicia a instrução ao sósia. O que nos interessa observar são as pausas, repetições e dúvidas:

\begin{tabular}{|c|c|}
\hline je $\mathrm{d}$ & $\begin{array}{l}\text { [alors tu vas me raconter... tous ce que je dois faire tous les activit/ tous ce que } \\
\text { en classe... le samedi }\end{array}$ \\
\hline M: & [oui \\
\hline p.S : d & \\
\hline p.M: $\mathrm{C}$ & out à fait... alors... ce samedi-là tu auras un niveau quatre \\
\hline P : : d & \\
\hline Ego & $\begin{array}{l}\text { urs il est avec le livre... bon tu/ tu auras le livre sur toi... le livre:.... celui-là l'Alter } \\
\text { IX }\end{array}$ \\
\hline P.S : u & \\
\hline & travailler le dernier contenu... parce que le semestre finira bientôt \\
\hline $\begin{array}{l}\text { M: } \\
\text { com } \\
\text { soix }\end{array}$ & $\begin{array}{l}\text { tu... tu commences par::... ahn::: c'était quoi déjà?... c'était... ce/ce::... tu } \\
\text { par la correction des exercices... c c'est/donc c'est la pa::ge::... soixante-six et } \\
\text { ze et tu vas pas corriger tous les exercices parce qu'il y a peu de temps:: }\end{array}$ \\
\hline
\end{tabular}

Excerto da segunda IS 
Acreditamos que as hesitações ocorrem no momento em que o enunciador está refletindo sobre o seu trabalho. No caso acima, Mariana procura refletir sobre qual é a primeira atividade da aula, percebemos que após as pausas, as repetições e uma dúvida (“c'était quoi déjà?”), ela expõe como a aula será iniciada: pela correção dos exercícios. Veremos nos resultados do estudo dos mecanismos enunciativos que Mariana não gosta de fazer a correção de exercícios/tarefa. Parece importante adiantarmos essa informação, para pensarmos que as hesitações preenchidas por repetições, do exemplo anterior, podem ter relação com este fato.

\subsubsection{Mecanismos de textualização}

Assim como na primeira IS, a análise da coesão nominal dos textos de segunda IS também permitiu a identificação das representações dos participantes da situação de trabalho de Mariana. No entanto, como a segunda IS foi voltada para as instruções das atividades desenvolvidas em sala de aula, os participantes presentes nestes textos são majoritariamente alunos. A retomada dos alunos nos textos se apresenta com pronomes, nomes próprios e alguns sintagmas nominais, alguns exemplos são: ele(s), alunos, a(s) pessoa(s), colegas, um grupo, todo mundo, alguns etc. Abaixo, temos um excerto com algumas retomadas dos alunos:

319. S: ah:: comment je ferais ça?

320. M: parce que... tu verras il y a:: trois ou quatre élèves qui prennent tou-jours la parole 321. S: uhum

322. M: eh:: Carlos... un monsieur:: ((risos))... bon tu verras... qui c'est... Carlos... ahn::.:.: un monsieur très gentil mais qu'arrive pas à faire une phrase::... sans fau::te ahn:::

323. S:

[mais il parle toujours?

324. M: oui il parle il parle il essaye de participer il est gentil... une fille un peu qui sait rien... de ce qu'elle parle... et::: une autre... une dame-là... donc:: ils vont prendre la parole tu les écoutes quand même mais tu dis aux/à ceux qui sont silencieux tu demandes à ceux qui sont silencieux... "et toi Iziel?" parce qu'Iziel il est toujours en silence... "et toi Iziel qu'est-ce que tu en penses?" "ah le même que mes collègues" "oui mais raconte-nous ce que tes collègues:: viennent de dire"

325. S: ah oui alors là je nomme et je pose les demandes et je... et quand même je j'essaye de:: extraire une réponse là?

326. M: oui parce que si tu fais pas (sic) ça:: ils vont pas dire même parler... parce que les autres... ils sont un gros groupe ils sont dix-huit

327. S: uhum

328. M: les autres prennent toujours la parole

Excerto da segunda Instrução ao Sósia 
Neste excerto, é possível compreender que Mariana classifica seus alunos como aqueles que tomam a palavra e os que não tomam a palavra. Para retomar o primeiro grupo, Mariana escolhe os seguintes termos: alunos; Carlos; um senhor; ele; uma moça; uma senhora; eles; os outros. Já o segundo grupo é retomado por: aqueles que são silenciosos; Iziel; ele(s). Para se referir a todos os alunos, Mariana usa: um grupo grande e eles. Vale ressaltar que neste excerto a enunciadora utiliza o discurso direto para instruir o que a sósia tem que dizer aos alunos e como o aluno pode responder ao professor. Neste momento, estão presentes a voz do professor e de um aluno, este último retoma o grupo de amigos que falam bastante com o uso de meus colegas, já a professora fala diretamente com um aluno que que pertence ao grupo não muito falante, retomando o aluno com o termo você e refere-se ao grupo dos que falam bastante com o uso de seus colegas:

\begin{tabular}{|c|c|c|c|}
\hline $\begin{array}{c}\text { Alunos mais } \\
\text { falantes }\end{array}$ & $\begin{array}{c}\text { Voz da Enunciadora } \\
\text { ele; uma moça; uma } \\
\text { senhora; eles; os outros }\end{array}$ & $\begin{array}{c}\text { Voz do aluno (discurso } \\
\text { direto) }\end{array}$ & $\begin{array}{c}\text { Voz da professora } \\
\text { (discurso direto) }\end{array}$ \\
\hline $\begin{array}{c}\text { Alunos menos } \\
\text { falantes }\end{array}$ & Iziel; ele(s) & -- & Seus colegas \\
\hline $\begin{array}{c}\text { Todos os alunos } \\
\text { da sala }\end{array}$ & um grupo grande; eles & -- & Você \\
\hline
\end{tabular}

Quadro 31: A retomada das figuras humanas da segunda IS

\subsubsection{Mecanismos enunciativos}

Como já explicamos, segundo Bronckart (1999/2009), as modalizações deônticas estão apoiadas em valores, opiniões e regras do mundo social. Acreditamos que com a análise destas modalizações, podemos verificar quais são as prescrições implícitas e explícitas no contexto de trabalho de Mariana. Nesta segunda instrução ao sósia, a professora-enunciadora utiliza-se de algumas modalizações deônticas para indicar que:

- a sósia deve fazer uma revisão assim que o primeiro aluno apresentar uma resposta errada durante a correção dos exercícios;

- a sósia deve fazer todo mundo falar, deve ouvir a voz de todos;

- a sósia deve primeiro falar e depois escrever quando explicar algo;

- é preciso ter paciência para corrigir os exercícios de casa.

Abaixo listamos alguns excertos em que estão presentes as modalizações deônticas: 
362.M: tu dois faire tout le monde parler... même si c'est... tout peu

363.S: oui

364.M: tu dois écouter la voix de tout le monde... une fois au moins ((risos))

365.S: ça c'est un critère qui doit... que je dois faire beaucoup d'attention

366.M:

[oui

Excerto da segunda Instrução ao Sósia

476.M:

[oui... ahn::: quand tu exPLlique tu dois écrire... ET parler

477.S: en même temps?

478.M: non:: d'abord tu par::les et après tu écris

Excerto da segunda Instrução ao Sósia

58.M: donc:: parfois ils disent "non:: ça va tranquille on a très bien fait" et c'était tout mauvais... donc il faut corriger je sais qu'il faut corriger... mais c'est triste parce que quand j'arrive en salle de classe je prends mon planning je vois qu'il faut faire la correction... mon dieu je sou::ffre et je dis non il y aura je vais dépenser quinze vingt... une demi-heure peutêtre... pour corriger les exerClces.. tout le monde seras fatigué à la fin... pour moi c'est fatigant la correction à la fin de la correction des exercices... et:: j'aime pas j'aime/je déteste en fait la correction des exercices... dans les cursos extras il y a un deux trois je sais pas combien de réunion où on parlais:: la correction des exerc/exercices... je pense que c'est c'est un:: c'est je sais même pas:: le proverbe en portugais ossos/ossos do ofício ou ócios do ofício?

Excerto do retorno à segunda Instrução ao Sósia

No último excerto, identificamos uma prescrição que já apareceu nos diários de aula: a correção dos exercícios, que foi por nós considerada uma prescrição/orientação implícita para o trabalho de Mariana, pois está associada ao gênero profissional (CLOT et al. 2000), por se tratar de uma maneira de se fazer que é difundida na profissão (FAÏTA, 2004). O verbo devoir, dever em francês, e a expressão il faut, que pode ser traduzida como é preciso, é necessário, indicam que corrigir os exercícios é uma prescrição forte para o trabalho de Mariana.

Mariana sabe que é preciso fazer as correções dos exercícios, no entanto, ela usa modalizações apreciativas para indicar que não gosta desta atividade de trabalho. Destacamos dois excertos a respeito desta questão:

36.M: en fait si je suis... franchement je pense un peu ça parce que:: je leur ai demandé de faire l'exercice ils savent qu'ils doivent le faire pour... bon pour étudier pour travailler pour apprendre... et:: ils ne font pas les exercices... et ils arrivent en cours on commence la correction déjà la correction je l'aime pas:: vraiment c'est quelque chose qui me déran::ge il faut avoir de la patien::ce là là là

Excerto do retorno à segunda Instrução ao Sósia

58. M: donc:: parfois ils disent "non:: ça va tranquille on a très bien fait" et c'était tout mauvais... donc il faut corriger je sais qu'il faut corriger... mais c'est triste parce que quand j'arrive en salle de classe je prends mon planning je vois qu'il faut faire la correction... mon dieu je sou::ffre et je dis non il y aura je vais dépenser quinze vingt... une demi-heure peut-être... pour corriger les exerClces.. tout le monde 
seras fatigué à la fin... pour moi c'est fatigant la correction à la fin de la correction des exercices... et:: j'aime pas j'aime/je déteste en fait la correction des exercices... dans les cursos extras il y a un deux trois je sais pas combien de réunions où on parlais:: la correction des exerc/exercices... je pense que c'est c'est un:: c'est je sais même pas:: le proverbe en portugais ossos/ossos do ofício ou ócios do ofício?

Excerto do retorno à segunda Instrução ao Sósia

Assim como no diário de aula IV, Mariana expõe uma avaliação negativa sobre a correção de exercícios (eu detesto, eu sofro, é cansativo etc.). Nesse caso, percebemos que essa prescrição implícita traz sofrimento para o seu trabalho.

Ainda analisando os mecanismos enunciativos, constatamos a presença de algumas vozes nos textos. A voz predominante nas instruções e discussões é a voz do professor/enunciador, que se apresenta, em alguns excertos, em discurso direto. Também encontramos em discurso direto as vozes dos alunos. No exemplo abaixo, destacamos a voz de um aluno e do professor:

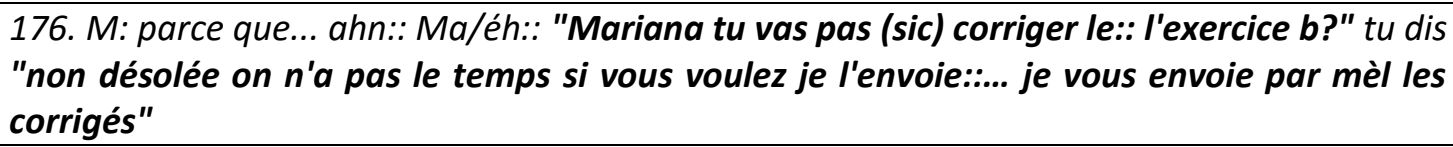

Excerto da segunda Instrução ao Sósia

As vozes representadas acima mostram a professora e os alunos em situação de ensino-aprendizagem, a enunciadora usa o recurso do discurso direto para mostrar o que a sósia deve dizer diante de um questionamento de um aluno sobre a correção de um exercício.

A voz do enunciador também se configura de outras maneiras nos textos, como nos casos abaixo, em que podemos identificar a voz da fala egocêntrica, tal como identificada por Lousada e Dantas-Longhi (2014):

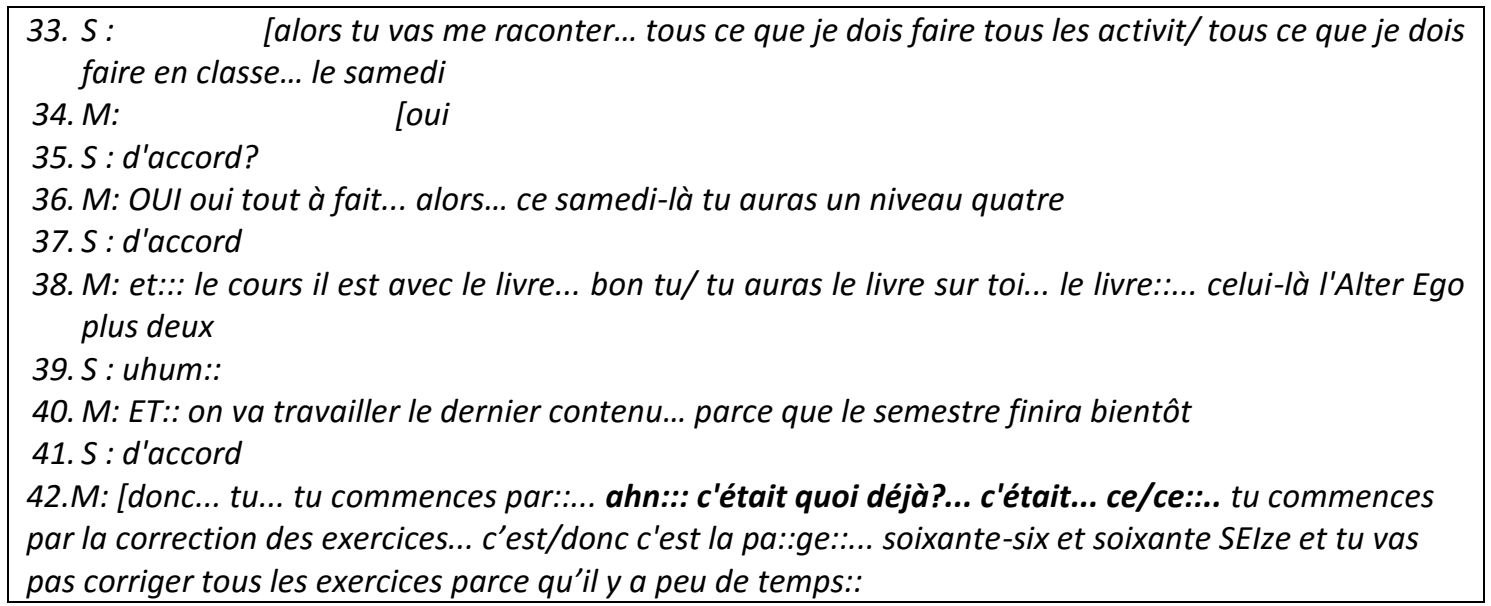

Excerto da segunda Instrução ao Sósia 
221. S : je dis::... éh:: comment je dis? comment je passe ça... d'une activité à l'autre?

222. M: après avoir demandé... "allez tout le monde est-ce que c'est claire? est-ce que:: vous avez toujours des questions? ah:: profitez-en... là c'est le moment::" et::... s'il y a personne tu dis "bon... alors... on avance d'accord? d'accord"

223. $S$ : uhum

224. M: et::: là tu mettras au tableau parce qu'il y a toujours ceux qui sont... () perdus... et tu mettras:: pa::ge soixante... souligné... sou-li-gné

225. $S$ : [souligné?

226. M: oui

227. $S$ : d'accord

228. M: [avec même avec un:: carré... au tour

229. S : il y a/ il y a de positons là? ah:: parce que là je dois mettre... ahn:: les les les exe/les petites phrases là:: des:: des rappels... ahn::

230. $M$ : [ah:: oui

231. S: dans ce coin vers SUR le tableau

232. M: $\quad$ [oui

233. S : là je dois mettre la page... alors il y a une disposition?

234. $M$ :

[bonne question... oui

235. $S:$ (...) ou je mets comme ça? peu importe

236. M: alors... tu/ah/il y aura le tableau... et le tableau il est pas (sic) trop grand... tu le partages en deux

237. S: oui::

238. M: c'est vrai... je sais pas (sic) pourquoi mais tu commences le tableau...ahn:: eh:: de... droi::te... à droit/non... tu commences le tableau par le coin... à droite et tu vas vers la gauche parfois... c'est un peu bizarre

239. S: oui

240. M: tu verras que tu vas commencer les explications enfin les petits rappels des questions versées

241. $S$ :

[uhum

242. M: (...) au coin à droite

243. S: $\quad$ [je vais mettre ça à droite?

244. M: oui

245. S: oui?

246. M: et après:: tu mettras page soixante où tu commenceras le contenu... à la partie gauche en haut

247. $S$ : oui::

248. M: mais pendant que tu mets:: les trucs en haut... tu effaces les petits rappels... et comme ça tu auras le:: tableau tout propre

249. $S$ :

250. M: oui

[ah:: j'efface l'autre côté?

251. $S:$ d'accord

252. M: oui parce que le tableau:: tout propre il il... il te::: il te plait

253. $S$ : d'accord:: je/je ne laisse pas les notes les rappels?

254. $M$ :

[non:: non

255. $S$ :

[j'efface tout?

256. $M$ :

[tu l'efface... oui

257. $S$ : oui et je recommence une:: une nouvelle histoire

258. M: oui... oui le tableau effacé

259. $S$ : d'accord

260.M: là::: ce/qu'est-ce que c'est déjà? ah c'est le superlatif

261.S: uhum

262.M: et::: on parle de::: de Paris:: de la province française... donc ils ont un petit TEXte là un extrait de::... un extrait de:: le Parisien

Excerto da segunda Instrução ao Sósia 
288.M: ET::.. ils/ils sont un peu paresseux enfin ils sont flemmards et:: c'est samedi matin j'insiste et donc:.... tu/après avoir passé/être/non/après... uh:: fugiu... après une minute... d'avoir commencé la lecture... tu leur demandes... "allez c'est fini?" "non::: Mariana::: calme-toi::" et tu dis "bon... on a du travail dépêchez-vous"

Excerto da segunda Instrução ao Sósia

Nos excertos em negrito, identificamos a voz da fala egocêntrica, o que significa que o professor/instrutor deixa de ter como destinatário o sósia e passa a ser seu próprio destinatário (LOUSADA e DANTAS-LONGHI, 2014). Nos dois primeiros excertos a fala egocêntrica opera como um organizador do pensamento, Mariana esquece algo e pergunta a si mesma, tentando se lembrar. No primeiro excerto, ao começar as instruções ao sósia, Mariana não se lembra exatamente qual o conteúdo que deve iniciar a aula, então faz uma pergunta a si mesma (“ahn.:. c'était quoi déjà?... c'était... ce/ce.:..”). Na sequência, Mariana se recorda ("tu commences par la correction des exercices"). É interessante observar que o conteúdo que Mariana se esqueceu é justamente o que ela diz não gostar/detestar em seus diários e nas entrevistas de IS: a correção dos exercícios.

No segundo excerto, Mariana instrui a sósia a anotar a página do livro na lousa para começar um novo conteúdo, então a sósia pergunta em qual parte da lousa ela deve fazer essa anotação. A partir dessa questão, Mariana explica a organização da lousa; porém, como essa explicação é um pouco longa, ela se esquece por um momento do conteúdo que seria abordado, assim pergunta e responde a si mesma, após se lembrar: “qu'est-ce que c'est déjà? ah c'est le superlatif”. Neste momento, há uma breve interrupção das instruções de Mariana à sósia e uma reorganização do seu pensamento, ou seja, a voz da fala egocêntrica apresenta-se para ajudar Mariana a se lembrar qual seria o conteúdo a ser trabalhado no momento descrito nas instruções. Vemos, tal como proposto por Lousada e Dantas-Longhi (2014), que a voz da fala egocêntrica serve como um instrumento para que Mariana aja sobre si-mesma na situação de instrução ao sósia e tenha acesso a aspectos do seu trabalho.

A voz da fala egocêntrica do último excerto apresenta uma diferença em relação aos dois primeiros: a língua utilizada. Mariana interrompe a instrução à sósia (produzida em língua francesa) com uma interjeição acompanhada de um termo em português "uh:: fugiu...". Isso ocorre no momento em que ela busca palavras em francês para se expressar “tu/après avoir passé/être/non/après...”. Fica claro que Mariana fala consigo mesma, já que em toda a entrevista ela se dirige à sósia em francês. A sua língua materna aparece diante da dificuldade de encontrar as palavras da língua estrangeira. Aqui podemos nos 
indagar sobre a língua de realização dos métodos de intervenção e sobre o papel da língua materna como via de acesso à língua estrangeira. Embora haja apenas duas ocorrências dessa voz e como não se trata de nosso objetivo nesta pesquisa, não nos alongaremos nessa discussão. Porém, parece-nos interessante notar essa ocorrência para futuros estudos.

Ainda sobre a análise das vozes, vimos que os resultados da análise dos diários de aula de Mariana mostram o recurso utilizado para pensar em seu trabalho: ela se coloca no lugar de aluna (tanto no passado quanto no presente) para comparar sua aprendizagem com a dos alunos. Encontramos este recurso também na segunda IS e no retorno à segunda IS.

462.M: (...) du Brésil... et alors:: ils vont voir entre eux... ET ils vont:: peut-être ils vont te demander:: "et en portugais ?" tu dis "bon en portugais quand on fait des comparaisons de:: et on emploie un superlatif c'est un peu la même chose... c'est qui change en français c'est l'article"

463.S: et ils demandent toujours des::... des::... comparaisons au portugais? ils utilisent ça comme stratégie?

464.M: euh:::: pas toujours... mais quand même... tu penses que parfois ça marche 465.S: d'accord

466.M: parce que quand tu étais étudiante de français::.. tu arrivais à voir des trucs quand quelqu'un t'expliquait en portugais parfois

Excerto da segunda Instrução ao Sósia

Mariana coloca-se no passado para instruir a sósia ("quando você era aluna de francês”) para pensar em estratégias de ensino. Esse recurso pode estar associado à falta de experiência profissional de Mariana, pois ao escolher a melhor estratégia de ensino, foi necessário comparar a aprendizagem dos seus alunos com sua própria aprendizagem, aparecendo a voz de Mariana-aluna.

A voz de Mariana-aluna também aparece em um excerto do retorno à segunda IS: 
36.M: en fait si je suis... franchement je pense un peu ça parce que:: je leur ai demandé de faire l'exercice ils savent qu'ils doivent le faire pour... bon pour étudier pour travailler pour apprendre... et:: ils ne font pas les exercices... et ils arrivent en cours on commence la correction déjà la correction je l'aime pas:: vraiment c'est quelque chose qui me déran::ge il faut avoir de la patien::ce là là là et:: et quand j'appelle je sais pas (sic) "Carmen:: l'exercice cinq s'il te plaît" "a:: mais j'ai pas fait (sic)" ((barulho)) ((risos)) les oui ah:: "oui mais essaye" "non j'ai pas fait je sais pas (sic)" vraiment ce que je pense c'est "je m'en fiche si tu n'as pas fait:: ((palmas)) vas -y::" c'est un peu comme ((palmas)) "dégage-toi allez allez allez" MAIS quand même en tant que/là:: peut-être là je pense ça en tant que sa collègue comme si j'aurais fait l'exercice... je :: voudrais bien faire attention à la correction et elle... elle dérange un peu le rythme du cours 37.S: uhum

38.M: MAIS quand même je suis pas (sic) sa collègue je suis sa prof... et:: même si je m'en Flche je dois pas (sic) m'en ficher/enfin c'est c'est quelque chose de/de/c'est un conFLIT ((risos))

Excerto do retorno à segunda Instrução ao Sósia

Neste excerto, Mariana revela que não gosta de fazer a correção de exercícios de tarefa, em seguida demonstra a falta de paciência com os alunos que não fazem esses exercícios e recusam-se a os fazer no momento da correção. Diante disso, ela explica que sua impaciência pode ser justificada pelo fato de ela se colocar na posição de uma colega de classe, que faz as tarefas: "eu penso nisso como sua colega". Mariana finaliza este trecho revelando um "conflito": "eu não sou sua colega eu sou sua prof”. A reflexão de Mariana mostra que seu conflito está associado a sua identidade que se divide entre Mariana-aluna e Mariana-professora.

Parece-nos importante destacar que Mariana refere-se como aluna para abordar o mesmo conteúdo temático - a correção dos exercícios - presente no diário II e no retorno da segunda IS. Isso ocorre, provavelmente, por dois motivos: i) devido à proximidade das produções do diário, escrito em 30 de março de 2014, e do retorno da segunda IS, gerado em 24 de abril de 2014 e ii) pelo movimento de reflexão na posição de aluno ser uma característica do professor iniciante, que não tem experiências como docente suficientes para superar os obstáculos encontrados.

\subsubsection{Figuras de ação}

Também analisamos as figuras de ação da segunda IS, procurando observar o posicionamento da professora participante diante da tarefa a ser realizada. Essa análise serviu de base para compreender quais são as representações de Mariana sobre o seu trabalho. Assim como no texto da primeira IS, na segunda IS também predomina a ação 
experiência. No entanto, diferentemente da primeira IS, em que o conteúdo não estava ligado ao ensino, mas à organização do ambiente de trabalho, a segunda IS é marcada por figuras de ação de experiência ligadas ao ensino-aprendizagem de FLE. Abaixo, retiramos um excerto para exemplificar a figura de ação experiência:

378. M: AH::: il y a une chose... pendant qu'ils pendant qu'ils:: ferons l'exercice trois celui des vrais faux... tu mettras au tableau tes phrases tes exem::ples ces trucs là comme ça tu profites le temps et/et ils restent pas (sic) sans rien faire

379.S: ah:: pendant qu'ils travaillent moi je je:: vais met/mettre les exemples au tableau? 380. M: oui exactement

381.S: et ils ont l'habitude que je fasse ça?

382. M: oui oui tu le fais toujours

383.S: d'accord

Excerto da Segunda Instrução ao Sósia

A figura de ação experiência retrata a cristalização de uma ação de Mariana, tal como Bulea (2010) o indica: enquanto seus alunos fazem os exercícios, ela escreve os exemplos da próxima explicação na lousa, para ganhar tempo e para os alunos que terminam a lição, não ficarem sem o que fazer. O que caracteriza a figura de ação experiência, neste excerto, é o discurso interativo e o uso do advérbio de tempo sempre (toujours), indicando a frequência de realização da tarefa.

Encontramos também a presença da figura de ação ocorrência, sobretudo em trechos com forte grau de contextualização do ambiente de trabalho e dos participantes. Nesta IS, a enunciadora centrou-se nas explicações das atividades realizadas em sala de aula, por isso, ela contextualiza o local com informações sobre os seus alunos, ou seja, os participantes envolvidos em situação de trabalho:

320.M: parce que... tu verras il y a:: trois ou quatre élèves qui prennent tou-jours la parole 321.S: uhum

322. M: eh:: Carlos... un monsieur:: ((risos))... bon tu verras... qui c'est... Carlos... ahn::.:: un monsieur très gentil mais qu'arrive pas à faire une phrase::... sans fau::te ahn:::

323.S:

[mais il parle toujours?

324.M: oui il parle il parle il essaye de participer il est gentil... une fille un peu qui sait rien... de ce qu'elle parle... et::: une autre... une dame-là... donc:: ils vont prendre la parole tu les écoutes quand même mais tu dis aux/à ceux qui sont silencieux tu demandes à ceux qui sont silencieux... "et toi Iziel?" parce qu'Iziel il est toujours en silence... "et toi Iziel qu'est-ce que tu en penses?" "ah le même que mes collègues" "oui mais raconte-nous ce que tes collègues:: viennent de dire"

Excerto da Segunda Instrução ao Sósia

Mariana apresenta dois grupos de alunos: os que vão "tomar a palavra" e os "silenciosos". A instrução é para que a sósia estimule os alunos mais quietos a falarem o 
que eles pensam sobre o assunto discutido. No entanto, Mariana apresenta um problema: esses alunos podem falar que pensam o mesmo que seus colegas, evitando prolongar uma discussão sobre o assunto. Diante disso, a solução encontrada é fazer com que eles expliquem o que estes colegas disseram. Assim, Mariana revela quem e como são os participantes envolvidos em situação de trabalho e os problemas e soluções encontrados neste contexto.

A figura de ação canônica é caracterizada no texto de segunda IS pela presença das regras e normas do contexto de trabalho de Mariana. Como exemplo, apresentamos um excerto em que Mariana indica a prescrição de correção de atividades:

58.M : donc :: parfois ils disent "non :: ça va tranquille on a très bien fait" et c'était tout mauvais... donc il faut corriger je sais qu'il faut corriger... mais c'est triste parce que quand j'arrive en salle de classe je prends mon planning je vois qu'il faut faire la correction... mon dieu je sou::ffre et je dis non il y aura je vais dépenser quinze vingt... une demi-heure peutêtre... pour corriger les exerClces.. tout le monde seras fatigué à la fin... pour moi c'est fatigant la correction à la fin de la correction des exercices... et:: j'aime pas j'aime/je déteste en fait la correction des exercices... dans les cursos extras il y a un deux trois je sais pas combien de réunion où on parlais:: la correction des exerc/exercices... je pense que c'est c'est un:: c'est je sais même pas:: le proverbe en portugais ossos/ossos do ofício ou ócios do ofício?

Excerto do retorno à segunda Instrução ao Sósia

Como já dissemos na análise das modalizações, a correção de exercícios aparece como uma prescrição para o trabalho de Mariana, que apesar de não lhe agradar, sabe que é preciso cumpri-la. Mariana define a correção dos exercícios "como ossos do ofício", tarefa que não é agradável, mas que não pode deixar de ser feita. "Ossos do oficio" revela a voz popular, que aparece por meio de um provérbio (MAINGUENEAU, 2011). É um mecanismo de inserção de vozes que mostra a sabedoria popular, manifestando, portanto, o que Clot (2007) nomeia de dimensão transpessoal do métier, ou seja, algo que está na história do métier, pelo fato de todos associarem ao trabalho do professor a correção de exercícios.

Assim como foi exposto na análise das figuras de ação da primeira IS, na segunda, a figura de ação acontecimento passado também foi encontrada nos excertos em que a enunciadora se posiciona no passado para comparar algo do passado com o presente. $\mathrm{Na}$ primeira IS, Mariana compara o início de sua atividade profissional com o momento atual, abordando os recursos utilizados (ficha e planejamento do tempo de cada atividade) que organizam seu trabalho. Já na segunda IS, Mariana analisa as estratégias de ensino- 
aprendizagem, refletindo sobre suas experiências no passado enquanto aluna. Para melhor compreender, retiramos um excerto da segunda IS:

463. S: et ils demandent toujours des::... des::... comparaisons au portugais? ils utilisent ça comme stratégie?

464. M: euh:::: pas toujours... mais quand même... tu penses que parfois ça marche

465. S: d'accord

466. M: parce que quand tu étais étudiante de français::.. tu arrivais à voir des trucs quand quelqu'un t'expliquait en portugais parfois

Excerto da Segunda Instrução ao Sósia

O posicionamento do enunciador no passado é caracterizado pela fórmula temporal "quand", seguido de verbo no tempo verbal imparfait, que corresponde ao pretérito imperfeito: "quando eu era aluna de francês (...)". Mariana revela uma estratégia de ensino, praticada atualmente, baseada em sua experiência como aluna. 


\section{CAPÍTULO IV - DISCUSSÃO DOS RESULTADOS}

Neste capítulo, propomos uma discussão a partir dos resultados das análises de nosso conjunto de dados (Guide du Moniteur, diários de aulas, instruções ao sósia e seus retornos) à luz dos pressupostos teóricos, relacionando-os com as nossas questões de pesquisa. Para tanto, organizamos essa discussão com nossas três questões apresentadas a seguir:

\section{1) Quais são as prescrições no trabalho do professor iniciante de língua estrangeira de um curso extracurricular em uma Universidade de São Paulo? Qual o seu papel? São explícitas ou implícitas?}

A maior parte das prescrições do contexto estudado é encontrada no documento de orientação do Guide du Moniteur. É o perfil do seu destinatário que configura todo esse documento a começar pela língua de produção do texto - o francês - que limita o acesso do leitor. Assim, o Guide du Moniteur não pode ser usado, por exemplo, por professores-monitores de outras línguas estrangeiras, ou até mesmo, por iniciantes no idioma, pois é voltado para aqueles que têm domínio da língua que será ensinada. É por esse motivo que, para compreendermos quais são as prescrições no trabalho da professora participante desta pesquisa, vemos a importância de mostrar como é vista essa professora no contexto estudado, porque acreditamos que as prescrições são definidas a partir de uma imagem que se tem do seu destinatário.

O resultado da análise do contexto de produção do Guide du Moniteur permite dizer que seus destinatários são bem específicos, diferentemente de outros documentos que orientam o trabalho do professor de francês, como no caso do $\mathrm{CECR}^{63}$, que define seus destinatários de forma abrangente, assim como aponta Menezes (2015, p.116): “Os destinatários do documento são os interessados no ensino e aprendizagem de língua francesa, quer sejam aprendizes, professores, coordenadores pedagógicos, diretores de escolas e gestores em geral, além do grande público que também possa se interessar pelo estudo da língua francesa". Ao contrário, os destinatários do Guide du Moniteur são bem precisos: são monitores ingressantes dos cursos Extracurriculares de francês com vínculo como alunos na mesma universidade onde se encontram esses cursos.

\footnotetext{
${ }^{63}$ Cadre européen commun de référence pour les langues
} 
Sabendo disso, as orientações e prescrições neste texto foram delineadas de acordo com o perfil do destinatário, caracterizado não como professor, mas como aluno, que está de passagem pela universidade e em um período de formação profissional: "vous êtes à l'Université de passage" (linha 329).

Assim como explicamos nos resultados das análises dos mecanismos de textualização, a imagem que a instituição tem da professora participante é construída no texto pelo emprego predominante do termo moniteur(s) (29 ocorrências), usado para designar o destinatário do texto, limitando o uso de professeur(s) (11 ocorrências) para indicar o métier de professor, como por exemplo em: "formation des professeurs" (Guide du Moniteur, linha 279). Parece-nos interessante apontar para o fato de que os monitores dos cursos Extracurriculares de francês podem ter formação superior na área de atuação (Letras-francês), mesmo assim seu estatuto é de aluno de licenciatura ou de pósgraduação; esse fato, embora característico do estatuto desses monitores no local em que os cursos acontecem, já que se trata de alunos para a Instituição, não ocorre em outros contextos, como por exemplo, em escolas de ensino de LE, onde mesmo aquele sem formação específica na área é definido como professor.

Para definir as prescrições do Guide du Moniteur, também levamos em conta o resultado de análise da infraestrutura geral do texto, mais precisamente, o plano global dos conteúdos temáticos, que gira em torno de questões sobre a organização para o trabalho nos cursos Extracurriculares de francês (abertura de conta, pagamentos, salas de aulas, materiais para a aula etc.). Considerando as informações expostas até aqui, concluímos que predominam no Guide du Moniteur as prescrições administrativas, sendo que, as prescrições de cunho pedagógico circulam em reuniões pedagógicas mensais, indicadas tanto no Guide du Moniteur, quanto nas entrevistas de IS.

Considerando, ainda, as prescrições do Guide du Moniteur, constatamos a predominância das prescrições explícitas, definidas por Barricelli (2012), com base em alguns estudiosos do trabalho (AMIGUES, 2004), como tarefas claramente estabelecidas pela instituição ou pelos manuais, isto é, normas efetivamente declaradas. Sabendo disso, as prescrições do documento analisado são marcadas pela predominância de frases imperativas, identificadas na análise do discurso interativo, e pelas modalizações deônticas, (devoir e il faut).

A presença de prescrições explícitas e de muitas informações administrativas configuram o Guide du Moniteur como documento injuntivo, caracterizado por conter 
informações claras e diretas sobre o que o monitor deve/precisa fazer em seu contexto de trabalho, sem deixar muito espaço para interpretações subjetivas ou mal-entendidos por parte do monitor.

No capítulo dos pressupostos teóricos, em que abordamos o que são as prescrições no quadro das Ciências do Trabalho, vimos que a tarefa não é determinada pelo sujeito que a desempenha, mas por uma autoridade em posição hierárquica (AMIGUES, 2004; BERTHET e CRU, 2003; DANIELLOU, 2000). Com base nisso, investigamos o enunciador do Guide du Moniteur, que se revelou no resultado das análises ser um macroenunciador, formado por produtores e avalizadores do texto (monitores, exmonitores, assistentes da coordenação e coordenadora). Apesar desse macroenunciador englobar também a coordenadora (que o corrigiu), vimos que os coenunciadores mais expressivos são aqueles que produziram o texto: os monitores e ex-monitores, já que a coordenadora não se coloca como enunciadora no texto ("nossa coordenadora", Guide du Moniteur, linha 41). Dessa forma, apesar da distância hierárquica entre enunciadores e destinatários, característica de textos prescritivos no ambiente de trabalho, o Guide du Moniteur mostrou uma particularidade: seu caráter de proximidade entre enunciadores e destinatários. Isso ocorre porque os enunciadores do documento desempenham a mesma função dos seus destinatários: todos são monitores.

Os elementos linguísticos podem comprovar essa proximidade, pois, pelo resultado da análise dos pronomes on e nous, observamos um enunciador difuso, que ora se coloca separadamente dos monitores recém-chegados, ora se coloca junto deles, fazendo parte do coletivo de trabalho. Além disso, há a presença de algumas frases exclamativas com tom amigável, para encorajar o recém-chegado ("Soyez le(a) bienvenu(e)!'”; “on est fiers de vous !’). Essas características mostram que não há uma separação tão acentuada entre os papeis ocupados no contexto de trabalho, ou seja, todos são monitores-professores de FLE. No entanto, é o movimento de distanciamento do enunciador e as características já expostas aqui, que caracterizam o Guide du Moniteur como um documento prescritivo, ainda que as prescrições veiculadas no documento não sejam tão explícitas.

Algumas prescrições foram identificadas também nos textos gerados pela professora participante, sobretudo por meio da análise das modalizações deônticas, já que estão apoiadas em valores ou regras do mundo social (BRONCKART, 1999/2009). A correção de exercícios/tarefa, que aparece em seus diários de aulas, na segunda IS e no 
retorno da segunda IS, é um exemplo dessas prescrições. Sabemos que a correção de exercícios faz parte do trabalho de um professor. Mesmo que não esteja explícito em documentos oficiais ou manuais pedagógicos, os professores sabem que é preciso corrigir os exercícios. Nesse sentido, consideramos que a correção de exercícios se encaixa no conceito de prescrição implícita, tratado por Barricelli (2012), à luz de outros estudos (AMIGUES, 2004), já que as prescrições implícitas estão no plano do subentendido, como por exemplo, o modo de se vestir, a postura esperada do profissional etc.

Em nossos dados, vimos que Mariana sabe o que deve ser feito e o indica por meio de modalizações deônticas com forte grau de injunção:

58.M: donc:: parfois ils disent "non:: ça va tranquille on a très bien fait" et c'était tout mauvais... donc il faut corriger je sais qu'il faut corriger... mais c'est triste parce que quand j'arrive en salle de classe je prends mon planning je vois qu'il faut faire la correction... mon dieu je sou::ffre (...)

Excerto do retorno à segunda Instrução ao Sósia

Mesmo sem estar explicitamente determinado, a correção de exercícios é encarada por Mariana como algo importante para seu trabalho. Sua preocupação pode revelar o que Saujat (2005) define como subentendidos da atividade dos professores experientes. Assim, entendemos que existe algo consolidado pelo coletivo, que faz parte do gênero profissional ou gênero da atividade, determinado por alguns autores (CLOT e FAÏTA, 2000; CLOT et al., 2000; FAÏTA, 2004) pela produção de "formas de fazer mais ou menos difundidas na profissão" (FAÏTA, 2004, p.64).

Porém, apesar de Mariana conhecer a importância da correção de exercícios, essa prescrição lhe causa insatisfação em seu trabalho:

58.M: (...) pour moi c'est fatigant la correction à la fin de la correction des exercices... et:: j'aime pas j'aime/je déteste en fait la correction des exercices... dans les cursos extras il y a un deux trois je sais pas combien de réunions où on parlais:: la correction des exerc/exercices... je pense que c'est c'est un:: c'est je sais même pas:: le proverbe en portugais ossos/ossos do ofício ou ócios do ofício?

Excerto do retorno à segunda Instrução ao Sósia

Ela usa modalizações apreciativas de valor negativo (eu não gosto, eu detesto, é cansativo) para expressar o que pensa sobre as correções. Assim, pensamos que a correção 
é uma maneira de fazer específica do gesto profissional (SAUJAT, 2005), que faz parte do gênero profissional, mas da qual Mariana ainda não se apropriou, o que lhe causa desconforto em seu trabalho.

Ainda com base no excerto acima, Mariana utiliza um provérbio em português para definir o que representa a correção de exercícios no trabalho do professor: "são ossos do ofício", ou seja, por mais que, para ela, seja uma tarefa incômoda ou desagradável, é uma tarefa obrigatória e necessária. Esse provérbio acolhe uma voz que pertence à "sabedoria popular" (MAINGUENEAU, 2001) indicando que a correção é algo que já faz parte da história do métier de professor. Isso mostra, portanto, a dimensão transpessoal do métier, que segundo Clot (2007), caracteriza o métier para além dos sujeitos e ao longo da história.

A correção de atividade pode ser vista também como uma prescrição vaga (AMIGUES, 2003), isto é, Mariana sabe o que ela precisa fazer, mas não é explicitado como ela deve fazer. Segundo Amigues (2003), o fator que contribui para aumentar a imprecisão da prescrição é a pluralidade de canais de sua difusão; no trabalho do professor, temos livros pedagógicos, documentos prescritivos, reuniões pedagógicas etc. A partir disso, para que seu trabalho seja possível, o professor precisa organizar as prescrições vagas (AMIGUES, 2004), redefinindo-as para que o trabalho possa ser realizado (DAGUZON e GOIGOUX, 2007). Sendo assim, há um trabalho de reconcepção da tarefa (AMIGUES, 2009) que a transforma em uma autoprescrição. No caso da correção de exercícios, sabemos que há exercícios para casa nos livros didáticos, mas em nenhum local é indicado como corrigi-los, então Mariana faz uma autoprescrição dessa tarefa apoiando-se em seus próprios recursos.

Com isso, destacamos algumas outras prescrições implícitas, que podem ser consideradas como uma autoprescrição de Mariana para seu trabalho. Todas elas são expressadas por modalizações. As primeiras são identificadas nas frases que aparecem na segunda IS: "você deve fazer todo mundo falar" e "você deve escutar a voz de todo mundo":

362. M: tu dois faire tout le monde parler... même si c'est... tout peu 363.S: oui

364. M: tu dois écouter la voix de tout le monde... une fois au moins ((risos))

365.S: ça c'est un critère qui doit... que je dois faire beaucoup d'attention 366.M:

[oui

Excerto da segunda Instrução ao Sósia 
Assim como no caso da correção de exercícios/tarefas, geralmente, não é preciso dizer explicitamente aos professores de FLE para fazer todos os seus alunos participarem ativamente da aula, pois essa ideia já está implícita para eles. O material didático do professor, por exemplo, já traz informações de como organizar a turma para todos se expressarem em determinado exercício, ou seja, implicitamente há uma prescrição de que todos devam falar. No entanto, não são todos os professores que se propõem a cumprir essa prescrição. O caso de Mariana é diferente, pois, ao contrário do que ocorre com as correções, que ela diz saber que é preciso fazer, nesse caso, ela diz que deve fazer e deve ouvir todo mundo falar. Nesse sentido, consideramos essas últimas autoprescrições que ela impõe a si-mesma a partir das prescrições gerais sobre o trabalho do professor, com as quais ela concorda, diferentemente do que ocorre com as correções de exercícios.

Outra autoprescrição no contexto de Mariana aparece na primeira IS, revelada nas frases: "parce que tu veux faire la pause" ( $1^{\mathrm{a}} \mathrm{IS}$, turno $\left.443 \mathrm{M}\right) \mathrm{e}$ "... tu dois faire la pause" ( $1^{\text {a }}$ IS, turno $\left.461 \mathrm{M}\right)$, destacando o intervalo no contexto de trabalho. As afirmações querer e dever fazer o intervalo são ditas logo após a sósia perguntar se era possível não fazer o intervalo para a aula acabar mais cedo, já que Mariana diz que tem que repor o tempo do intervalo. Diante disso, vemos uma prescrição implícita (fazer o intervalo) não obrigatória para o trabalho do professor, que pode (ou não) cumpri-la. No caso de Mariana, fazer o intervalo é um dever e um querer.

Notamos que essa prescrição tem duas motivações, ambas vindas de Mariana. A primeira tem foco na qualidade do ensino-aprendizagem, já que Mariana diz que o intervalo deve ser feito para que o ritmo da aula não diminua "et... sinon... tu verras que : le rythme... il/ il commence à ((expirou)) dev/ il devient pire...” ( $1^{\mathrm{a}} \mathrm{IS}$, turno $\left.451 \mathrm{M}\right)$. Além disso, o momento do intervalo deve ser escolhido de acordo com o que a fisionomia dos alunos revela (fome, cansaço etc.) "s'ils ont des visages de faim... tu dois faire la pause" (1 ${ }^{\mathrm{a}} \mathrm{IS}$, turno $283 \mathrm{M}$ ). Nesse exemplo, vemos a razão pela qual o métier é interpessoal (CLOT, 2007), isto é, a atividade de Mariana não é isolada, ela tem como destinatários seus alunos. A segunda motivação tem foco em suas próprias decisões: vemos a prescrição de fazer o intervalo ligada ao “querer", pois é um momento de repouso para Mariana tomar um café, ir ao banheiro etc.: "( ) tu dois prendre un café... tu dois aller aux toilettes..." ( $1^{\mathrm{a}} \mathrm{IS}$, turno $\left.449 \mathrm{M}\right)$. Com isso, podemos dizer que Mariana organiza seu trabalho de tal maneira para criar um ambiente que favoreça sua própria aprendizagem, característica, segundo Amigues (2003), do trabalho do professor 
iniciante. Além disso, a preocupação de Mariana com o intervalo pode ter relação com uma preocupação com sua própria saúde, já que a saúde no trabalho está ligada à ideia de fabricação de novas normas criadas pelos trabalhadores diante das dificuldades enfrentadas (SAUJAT, 2007). Usando os termos de Clot (2003, p.5): "Diremos, então, agora que a luta contra as "doenças do trabalho" consiste menos em suprimir as doenças e mais em cuidar da saúde, ou seja, desenvolver "entre as coisas" relações que não surgiriam sem nós, que são o produto da atividade humana". Nesse sentido, podemos dizer que Mariana tem a percepção de que precisa do momento do intervalo aparentemente para os alunos, mas, de maneira mais profunda, para si-mesma, já que saber que os alunos estão contentes com sua aula pode contribuir para sua saúde, em sentido amplo, no trabalho.

Uma vez tendo respondido à primeira pergunta de pesquisa, passemos para a segunda.

\section{2) Como o professor iniciante concebe seu trabalho? Quais são as representações sobre} seu trabalho, sobre si enquanto professor e sobre os participantes da situação de trabalho?

Com o estudo dos elementos linguísticos e discursivos dos diários de aula, vimos que Mariana pode assumir dois papéis em seus textos: professora e aluna. Enquanto professora, ela aborda questões sobre seu métier: como organizou a aula, o que e como explicou a seus alunos etc. Seu perfil como professora é assumido quando trata de questões sobre seu trabalho. Para tanto, em alguns casos, estão presentes o substantivo travail (trabalho) e verbos do infinitivo travailler (trabalhar) para indicar as atividades desempenhadas. Sobre esse aspecto, consideramos que Mariana poderia ter utilizado outros termos, como por exemplo: explicar, ensinar. No entanto, a escolha por trabalho e trabalhar pode indicar sua perspectiva sobre a atividade de um professor, que vai além da sala de aula com os alunos (AMIGUES, 2004), onde ele explica e ensina. Essa visão está provavelmente associada aos seus estudos, já que as linhas de sua pesquisa no Mestrado são as mesmas da presente pesquisa - consideram o ensino como trabalho (AMIGUES, 2004; FAÏTA, 2004; SAUJAT, 2004)

A respeito da visão de Mariana sobre seu trabalho, o resultado da análise dos mecanismos de textualização de seus diários de aula permite fazer as seguintes reflexões: i) para o professor iniciante de LE é importante dominar os conteúdos linguísticos, 
inclusive a organização do seu trabalho pode se desenvolver em relação a esses conteúdos; ii) o trabalho do professor vai além das atividades desenvolvidas em sala de aula com os alunos (AMIGUES, 2004). Para exemplificar essas ideias, trazemos alguns excertos dos diários de Mariana, em que ela define o que é trabalho: "estudar, conhecer as regras para bem explicá-las e encontrar atividades interessantes" (diário de aula I, linhas 10) e relaciona os conteúdos linguísticos com o trabalho "eu comecei a trabalhar com eles ontem o passado composto versus o imperfeito, e isso não deu muito certo como eu imaginava" (diário de aula II, linha 35).

A preocupação de estar bem preparado antes das aulas, estudar, conhecer as regras, conceitos, entre outros, mostra uma característica do professor iniciante de LE: a preocupação com o domínio da língua ensinada, visto que ele pode não ter tanta segurança quanto a isso, assim como Mariana: "eu me sinto, desta vez, mais segura de mim mesma para trabalhar com os alunos". Buscando superar os obstáculos encontrados na situação de ensino, Mariana estuda, organiza e redefine seu trabalho (AMIGUES, 2004).

A enunciadora ainda assume o papel de professora nos diários quando aproveita a experiência que teve com sua turma anterior, que estava no mesmo nível de sua turma atual, para refletir sobre as práticas que deram certo e as que não deram certo. Em um dos excertos, por exemplo, Mariana recorda-se de como ela organizou suas aulas com a turma anterior e, a partir disso, explica o que ela fará de diferente para melhorar a aprendizagem dos alunos. Esse trecho pode manifestar uma característica do professor iniciante, já que Mariana está diante de uma situação de ensino que será, provavelmente, vivida pela segunda vez. Nesse caso, ela se apoia nessa única experiência para organizar seu trabalho, tentando fazer diferentemente do que foi feito antes, mas sem a certeza de que vai dar certo.

Foi a análise dos diários, da segunda IS e seu retorno que permitiu um olhar mais atento para as representações que Mariana tem de si própria. A análise mostrou principalmente as comparações realizadas pela enunciadora entre sua aprendizagem e a aprendizagem de seus alunos, revelando-nos a figura de Mariana-aluna. Mariana colocase no presente ou desloca-se para o passado (quando era aluna) para comparar sua aprendizagem com a de seus alunos. Essa comparação é usada como estratégia de ensino, ela procura ensinar da forma que achou mais fácil aprender. Em um dos trechos da segunda IS, Mariana diz para a sósia explicar alguns conteúdos fazendo comparações do francês com o português, pois era dessa maneira que ela compreendia alguns assuntos. 
Como suas referências de ensino são baseadas em sua própria aprendizagem, acreditamos que é difícil verificar uma distância significativa entre Mariana aluna e professora.

Em determinada passagem de seu diário de aula IV, Mariana coloca-se no passado denominando-se "étudiante de français". Segundo o dicionário virtual Larousse ${ }^{64}$ o termo étudiant faz referência ao estudante que frequenta curso superior. Sabemos que Mariana aprendeu o francês no curso de graduação em Letras, por isso podemos deduzir que o uso do passado acompanhado de étudiante indica o momento em que Mariana era aluna universitária, ou seja, quando ela se preparava para ser professora e ao mesmo tempo aprendia a língua estrangeira.

Em outro excerto, a posição de Mariana como aluna está no presente e nesse caso ela se refere como élève, termo em francês mais abrangente para dizer: aluno ${ }^{65}$. Como já dissemos, durante o processo de geração de dados, Mariana era aluna de Mestrado e terminava sua licenciatura em Letras. A partir disso, podemos pensar que o fato de Mariana ainda se ver como aluna para se comparar com seus alunos, evidencia mais ainda a pouca distância em que existe entre Mariana-aluna e Mariana-professora. É possível que um professor com uns 30 anos de carreira, por exemplo, não precise usar esse recurso (ver-se como aluno) para refletir sobre o processo de aprendizagem de seus alunos.

A voz de Mariana-aluna se apresenta no texto para refletir sobre questões de ensino-aprendizagem de FLE. Um dos temas abordados, como já dissemos, é a correção de exercícios. Como vimos, Mariana expressa que não gosta de corrigir exercícios/tarefas: "je n'aime pas la correction d'exercices" (Diário de aula IV, linha 68) e acrescenta que é pior quando o aluno não faz a tarefa e não tenta fazer no momento da correção. Também vimos que a enunciadora expõe uma avaliação negativa sobre a correção de exercícios no retorno da segunda IS, usando termos como: "eu detesto", "eu sofro" e "é cansativo", no entanto ela tem consciência de que esta atividade faz parte de seu trabalho, já que, como já dissemos acima, se trata da dimensão transpessoal do métier, proposta por Clot (2007).

Diante do conflito de não gostar das correções, Mariana compara sua atitude, enquanto aluna, com a de seus alunos. Diferentemente deles, quando ela não faz a tarefa, ela tenta ao menos fazer no momento da correção. Percebemos que a comparação que

\footnotetext{
${ }^{64}$ http://www.larousse.fr/dictionnaires/francais/\%C3\%A9tudiant/31593?q=\%C3\%A9tudiant\#31526 (acesso em 26/10/2014) ${ }^{65} \mathrm{http} / / / \mathrm{www}$. larousse.fr/dictionnaires/francais/\%C3\%A91\%C3\%A8ve/28394?q=\%C3\%A91\%C3\%A8ve\# 28257 (acesso em 26/10/2014).
} 
Mariana faz não colabora para solucionar o problema do incômodo que a correção lhe traz. Na verdade, a solução esperada por Mariana é que os alunos façam como ela faz (no papel de aluna).

Outras representações construídas por Mariana sobre si mesma enquanto professora, sobre seus alunos e o espaço de trabalho, são encontradas no resultado das análises dos mecanismos de textualização da primeira instrução ao sósia e seu retorno, nas seguintes metáforas: "a sala de aula é uma pequena sociedade [...] você é a rainha dessa sociedade [...] e os outros... eles são os:.: um pouco os subordinados" ( $1^{\text {a }}$ IS, turnos $565 \mathrm{M}$ e 569M). A figura da rainha representa para Mariana a imagem de uma professora autoritária/impositiva reconhecida por ela mesma no retorno à IS. Essa imagem aparece para organizar seu trabalho e controlar as situações de ensino-aprendizagem. A organização do trabalho de Mariana aparece já no início da primeira IS, com a preparação de uma ficha utilizada pela professora para não "se perder" nas aulas. Também encontramos essa preocupação com a regulação do trabalho em seus diários: a organização de calendários com as datas das provas, o estudo das regras dos conteúdos linguísticos, entre outros.

No entanto, algumas situações podem colaborar para a desestabilização desse controle. Um aluno que não faz os exercícios/as atividades de casa, por exemplo, prejudica o ambiente seguro criado pela professora; para manter esse controle, Mariana impõe um acordo: os alunos que não fizerem os exercícios devem tentar fazer no momento da correção. Outro fator, indicado pela professora, que pode prejudicar a gestão das atividades de um professor iniciante, é representado pelo aluno que pergunta demais durantes as aulas ("há uma senhora que sempre faz perguntas - ela começa a me atrapalhar um роисо [...]"); acreditamos que esse aluno pode levar a aula para um rumo não programado pela professora, fazendo perguntas que não tem nada a ver com os conteúdos ensinados no dia e isso contribui para o desconforto do professor. Justamente pelo fato de Mariana ser uma professora iniciante, ela parece não apreciar quando a aula toma um rumo inesperado por ela.

Ao escutar-se nas instruções dadas à sósia, Mariana depara-se com algo que ela nunca havia pensado: "eu jamais tinha pensado na minha maneira autoritária de separar os alunos misturando-os para que os mais fortes possam ajudar os mais fracos, fazendoos interagir... eu sei bem que há outras formas de organizá-los... com bolinhas de papel por exemplo... é verdade que eu nunca fiz isso... sou sempre eu que controlo o poder de 
os separar" (retorno à 1"IS, turno 199.M.). Com isso, como já dissemos nos resultados das análises, compreendemos que a IS é um método que permite a intervenção na situação de trabalho, Mariana tomou consciência de algo que não estava claro para si. Dessa forma, ela pode desenvolver outras maneiras de agir na situação, ou, nos dizeres de Clot (2008), poderia desenvolver seu "poder de agir" em relação a maneiras de fazer que a incomodam, pelo fato de reviver a experiência vivida.

A análise dos mecanismos de textualização e dos mecanismos enunciativos nos textos de IS e retornos também indicam as representações dos participantes presentes no trabalho de Mariana. O grupo de professores-monitores é dividido pela enunciadora entre aqueles que são seus colegas mais próximos e aqueles menos próximos. A distinção é marcada ao dizer o que faz para que seu ambiente de trabalho fique mais agradável: ela escolhe os colegas mais próximos, denominados de "amigos", para acompanhá-la em alguns trajetos, como por exemplo, da sala dos monitores até a sala de aula e para ir embora dos cursos. Os professores-monitores que não são seus colegas próximos são representados no texto da primeira IS por vozes que incomodam Mariana em dois aspectos: primeiro, por reprovarem sua atitude de chegar animada na sala dos monitores aos sábados de manhã; segundo, por passarem a impressão de avaliarem seu nível de francês ao insistirem em uma conversa em LE, mesmo quando Mariana demonstra não estar interessada em conversar em LE.

Ao escolher seus colegas de trabalho mais próximos - os seus amigos - para as interações nos momentos em que está fora da sala de aula, é possível pensar que essas conversas não são necessariamente relacionadas ao ensino do FLE e, provavelmente, são assuntos mais informais e em português. Nesse sentido, tratamos da "linguagem no trabalho" abordada por Nouroudine (2002, p.24):

\footnotetext{
conversar sobre a vida pessoal de um ou de outro, sobre os problemas da política atual, fazer observações sobre as ferramentas empregadas no setor vizinho ou na empresa concorrente, comentar o jogo de futebol da véspera etc. - todos esses assuntos fazem parte da linguagem no trabalho, uma vez que favorecem trocas na situação de trabalho.
}

Segundo Nouroudine (2002), por mais que a "linguagem no trabalho" não participe diretamente da atividade específica, em nosso caso o ensino de FLE, ela é necessária no ambiente de trabalho, pois pode contribuir para atenuar os efeitos de fadiga mental e/ou física. 
Outra divisão dos participantes é entre os monitores-tutores e os monitores"tutorés"; o primeiro grupo é visto por Mariana com um grupo formado por professores mais experientes: "des profs plus expérimentés" (discussão da IS1, turno 60); o segundo, ela considera como um grupo de iniciantes em ensino de FLE e é nesse grupo que ela se inclui: "vu que je suis débuTANte... ici on a un programme de tutorat" (discussão da IS1, turno 59). Mariana explica que os professores se reúnem para que os tutores auxiliem os "tutorés" a organizar as aulas, a guiar o trabalho e dar ideias: "on a un rendez-vous pendant la semaine... et là on essaie d'organiser le cours suivant" (discussão da IS1, turno 59). No entanto, o programa de tutoria não ajuda na preparação de todas as turmas dos "tutorés"; sendo assim, Mariana precisa preparar as outras aulas sozinha; esse trabalho de preparação fora do programa de tutoria é considerado por Mariana "um trabalho um pouco solitário": "pour mes autres groupes... que je ne fais pas de tutorat $: . . .$. je prépare moi ...... chez moi ....... C'est/ c'est un travail un peu solitaire je dirais" (discussão da IS1, turno 59).

Sabendo dessa configuração do contexto de trabalho de Mariana, consideramos, ao lado de Clot (2007), que a atividade de trabalho não é isolada, por isso o autor propõe o conceito de dimensão interpessoal do trabalho. Nesse sentido, o professor se relaciona com seus alunos, mas, também, com seus colegas de profissão. Esse coletivo de trabalho é importante, como explica Amigues (2003), no sentido de que ele organiza o ambiente de trabalho, mobilizando-se para desenvolver uma resposta comum às prescrições (AMIGUES, 2004), redefinindo, assim, as tarefas. Portanto, para Amigues (2003, p.11): “esses coletivos podem assegurar, dependendo da instituição, várias funções: uma mediação entre o prescrito e o realizado, uma fonte de autoprescrição, um meio de construir ferramentas, um apoio ao engajamento pessoal, etc." ${ }^{.66}$.

Após termos respondido à segunda pergunta de pesquisa, apresentaremos, a seguir, a resposta à terceira pergunta.

\footnotetext{
66 Tradução nossa do original: ces collectifs peuvent assurer, selon les établissements, diverses fonctions : un relais entre le prescrit et le réalisé, une source d'auto-prescription, un moyen de construire des outils, un soutien à un engagement personnel, etc.
} 
3) Quais elementos caracterizam a situação de trabalho nos cursos Extracurriculares de francês? Quais são as soluções encontradas pelo professor para executar seu trabalho nessa situação?

A respeito dos elementos que caracterizam a situação de trabalho da participante, notamos, com o resultado da análise da primeira IS, que Mariana se atém a uma ficha preparada antes de sua aula. Nela há informações sobre o conteúdo, o tipo de habilidade, o tipo de interação, a marcação do tempo de cada atividade etc. Não há referência a essa ficha no Guide du Moniteur, mas imaginamos que ela pode estar presente em reuniões pedagógicas ou ainda em encontros do programa de tutoria, visto que, na discussão da primeira IS, Mariana diz que aprendeu a fazer essa ficha, e que antes dela fazia rascunhos: "parce qu'avant/ avant d'apprendre à faire cette fiche... je faisais des brouillons..." (1 ISS, turno 171M). Sabendo que um dos propósitos dos cursos Extracurriculares é oferecer formação continuada aos professores (GUIMARAES-SANTOS, 2012; ROCHA, 2014; MELAO, 2014;), provavelmente, essa aprendizagem ocorreu neste contexto de trabalho. Mariana define a ficha como um esquema do curso e acrescenta um uso bem particular desta ficha:

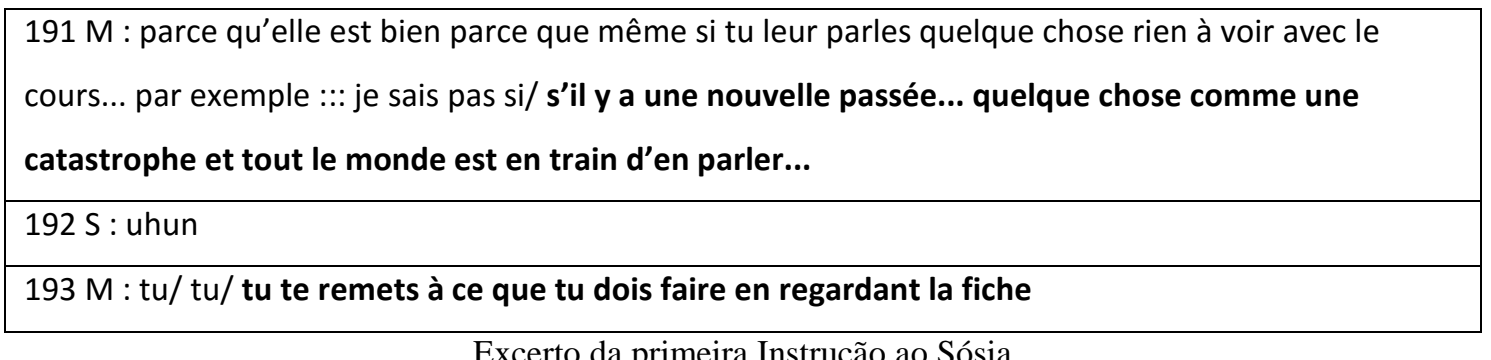

A enunciadora explica à sósia que se ela falar alguma coisa que não tem nada a ver com a aula ou, se acontecer um imprevisto, ela retoma o que tem que ser feito, olhando para ficha. Para exemplificar, Mariana cita um exemplo: acontece "alguma coisa como uma catástrofe e todo mundo está falando”. Diante desse exemplo, é possível imaginar que isso já pode ter acontecido com Mariana, que resolveu o problema com o uso da ficha, indicando que ela está presente em seu trabalho como um auxílio, não somente para organizá-lo, mas para dar segurança à Mariana, para que ela não fique perdida durante a aula. Ou seja, mesmo que, por algum motivo, o assunto/tema da aula seja direcionado para outro rumo, Mariana, com ajuda de sua ficha, retoma o que está previsto para sua aula.

Outro aspecto abordado sobre o contexto de trabalho de Mariana é o intervalo de aula presente na primeira IS. Ela explica à sósia que o curso tem 3 horas de duração mais 
15 minutos de intervalo, quem decide o melhor momento para se fazer essa pausa é o professor. Estes 15 minutos devem ser recuperados, portanto, a aula começa às $9 \mathrm{~h}$ e termina às $12 \mathrm{~h} 15$. A sósia, em determinado momento, pergunta se é possível não ter o intervalo para sair às $12 \mathrm{~h}$. Mariana diz que não, e nesse momento, revela a importância do intervalo para ela mesma e para seus alunos: "tu ne dois pas faire ça..." (turno 441) "tu veux faire la pause" (turno 443), "tu dois prendre un café... tu dois aller aux toilettes..." (turno 449).

Como dissemos, essa pausa para "tomar um café", "ir ao banheiro" permite, segundo Mariana, que o ritmo da aula não diminua. Assim, o tempo de pausa é considerado por ela fundamental. Isso é comprovado pela grande quantidade de modalizações deônticas ligadas ao dever ( $t u$ dois) e pela modalização apreciativa querer (tu veux). Com isso, concluímos que o intervalo é uma prática bem aceita por Mariana, usada como solução de um problema: a redução do ritmo da aula provocada pelo cansaço dos alunos e do professor. Nesse sentido, o métier é, segundo Clot (2007), pessoal, visto que cada situação é única, isto é, a prática de fazer o intervalo não é algo que deve ser esperado em todos os contextos de ensino de FLE nem de todos os professores, mas, para Mariana, é visto como algo vital para a execução do seu trabalho.

Uma das características do contexto estudado, e que pode ser vista como um problema enfrentado por Mariana, é a heterogeneidade dos alunos dos cursos, principalmente no desenvolvimento em sala de aula, pois há alguns que tomam a palavra e aqueles que praticamente não falam. Já dissemos que uma das prescrições implícitas para Mariana é fazer com que todos da turma interajam: "você deve fazer todo mundo falar"; "você deve escutar a voz de todo mundo". Diante dessa prescrição, para fazer com que os alunos mais quietos participem da discussão, Mariana diz que a sósia deve interrogá-los, envolvê-los na situação, perguntando sua opinião, por exemplo.

Outro elemento característico do contexto estudado é o grupo de professoresmonitores. Como já abordamos, Mariana divide o grupo de professores entre aqueles que ela tem mais afinidade e aqueles que são mais distantes. Para que o ambiente de trabalho fique mais agradável, ela escolhe seus colegas de trabalho mais próximos para conversar nos diferentes espaços que formam o local de trabalho. Mais uma vez, o que Mariana faz é uma característica do professor iniciante, que busca compensar as dificuldades provisórias para resolver os problemas com recursos intermediários (SAUJAT 2004b). 
Ou seja, para desenvolver seu trabalho, é importante para Mariana estar em um ambiente agradável, com pessoas que a deixem à vontade.

Com o exposto, vemos que Mariana encontra soluções que a preservam no contexto de trabalho, ou seja, que diminuem seu stress nesse contexto. Vemos, também, que o local de trabalho se caracteriza por trazer algumas características pré-estabelecidas, mas que, aparentemente, podem ser reformuladas. 


\section{CONSIDERAÇÕES FINAIS}

Esta pesquisa partiu de minha motivação pessoal em aprender a ensinar o francês como língua estrangeira, visto que no início dela, eu me encontrava nos primeiros anos da carreira de professor.

Abordando, agora, a pesquisa desenvolvida, concluímos que, centrado no professor iniciante de francês língua estrangeira (FLE), nosso estudo foi consolidado dentro de um núcleo de pesquisa que considera, ao lado de alguns estudiosos do trabalho (BRONCKART, 2004c; AMIGUES, 2004; FAÏTA, 2004; SAUJAT, 2004), a atividade de ensino como trabalho.

Nesse sentido, foi constituído um pequeno coletivo desenvolvido no núcleo de pesquisa ALTER-AGE/CNPq, formado por duas professoras iniciantes em FLE e alunas de mestrado (Mariana e a pesquisadora) e uma professora mais experiente em ensino de FLE e aluna de doutorado (Flávia). Nesse coletivo, pudemos pensar em questões sobre o trabalho de ensino de língua estrangeira, sobretudo desenvolvido por iniciantes, preocupações ligadas diretamente ao meu trabalho e ao de Mariana e indiretamente ao trabalho de Flávia, que também estuda o trabalho do professor. A constituição desse coletivo foi fundamental em nosso contexto de pesquisa, pois ele possibilitou as trocas de experiências tanto profissionais quanto acadêmicas. Além disso, acreditamos que um dos aspectos que deve ser levado em conta para compreensão do trabalho de modo mais geral é o que os trabalhadores falam sobre seu próprio trabalho (CLOT, 2013, p.8):

\footnotetext{
Uma das principais contribuições do gênero de clínica que fazemos, quando conseguimos fazer um bom trabalho, é que a qualidade do trabalho no contato com o real é considerada, por sua natureza, algo que certamente se discute. E sob essa perspectiva, o que já partilhamos é menos interessante do que aquilo que ainda não partilhamos. Assim, a única boa prática é talvez a prática do "debate profissional" entre "conhecedores" e, então, entre "conhecedores diferentes". Digamos de outro modo o que acabamos de dizer: a melhor maneira de defender um ofício é ainda questioná-lo cultivando os afetos, as técnicas e as emoções que o mantêm vivo.
}

Nessa perspectiva, pareceu-nos importante estabelecer esse coletivo no qual poderíamos ter um debate profissional, nos dizeres de Clot (2013), com "conhecedores" diferentes. Assim, optamos por utilizar esse coletivo para uma geração única de dados 
para duas pesquisas diferentes de Mestrado (esta pesquisa e a de Mariana), já que haveria pontos de vista diversos sobre o trabalho, emitidos pelos diferentes "conhecedores" do trabalho. Dessa forma, esta pesquisa está centrada no estudo do trabalho de Mariana e seu contexto, os cursos Extracurriculares de francês.

Retomada essa configuração da pesquisa, relembramos que temos por objetivo geral compreender o trabalho do professor iniciante de FLE dos cursos Extracurriculares de francês da FFLCH-USP. Mais precisamente, pretendemos: i) estudar o papel das prescrições/orientações no trabalho desse professor, procurando investigar como elas afetam seu trabalho; ii) estudar a atividade do professor a partir do que ele diz sobre seu próprio trabalho e sobre si mesmo como professor nesse contexto. Respondendo a esses objetivos específicos, visamos a refletir, de forma global, sobre como um professor iniciante aprende o trabalho de ensinar.

Apoiamo-nos em Machado e Bronckart (2004) que defendem a compreensão do trabalho educacional vinculada à análise das ações e dos textos que fazem parte de uma rede discursiva. Assim, eles analisam textos produzidos no interior de uma situação de trabalho e textos produzidos em situações "externas", principalmente, aqueles que prescrevem, planejam, avaliam etc. as ações desenvolvidas no contexto de trabalho (BRONCKART e MACHADO, 2004). Por esse motivo, analisamos textos produzidos pela professora participante após suas aulas - diários de aula, entrevistas de instrução ao sósia e seus retornos e um documento de prescrição/orientação do contexto de trabalho de Mariana chamado Guide du Moniteur.

Com base na afirmação de Amigues (2002, p.202) de que "as ações realizadas pelos professores não se limitam a uma simples execução do prescrito, mas a um trabalho de reelaboração do que ele precisa fazer em o que há para fazer nesta situação" 67 , analisamos a atividade do professor levando em conta o que é pedido para este trabalhador realizar, o que ele de fato realizou e também o que queria ter realizado, mas que por algum motivo não realizou (CLOT, 1999).

Após o caminho percorrido nesta pesquisa, apontamos as conclusões a que chegamos a respeito do trabalho do professor iniciante de FLE, além de indicar algumas limitações e nossas contribuições para o campo de estudos ao qual pertence.

\footnotetext{
${ }^{67}$ Tradução nossa do original: Les actions réalisées par les professeurs ne se limitent donc pas à une simple exécution du prescrit, mais à un travail de ré-élaboration de ce qu'il faut faire en ce qu'il y a à faire dans telle situation (destaque do autor).
} 
O contexto de trabalho do professor é caracterizado por prescrições que são vagas (AMIGUES, 2003), sendo assim, diferentemente dos professores mais experientes, apesar dos professores iniciantes saberem o que deve ser feito em seu trabalho, eles não sabem, exatamente, como fazer (LOUSADA, 2011). Essas prescrições estão no âmbito do implícito (AMIGUES, 2004; BARRICELLI, 2012) e podem ser compreendidas como subentendidos da atividade dos professores (SAUJAT, 2005), ou seja, modos de fazer já consolidados pelos professores mais experientes, que caracterizam o gênero profissional docente (CLOT e FAÏTA, 2000; CLOT et al., 2000; FAÏTA, 2004). Nesse sentido, o professor não precisa aprender todas as suas atividades, sempre que for trabalhar: ele pode se apoiar nos modos de fazer já consolidados. Em outras palavras, poderíamos pensar em locais de formação em que os futuros professores entrassem em contato com ações mais esperadas do métier de professor, sujeitas à discussão pelos pares, e não apenas às maneiras de fazer já consolidadas e que não são objeto de "reconcepção" (AMIGUES, 2009).

Justamente, para o iniciante faltam essas maneiras de agir reconhecidas pelo meio profissional. Um exemplo que aparece em nossas análises das IS e dos diários de aula é o da correção dos exercícios/tarefa de casa. O professor iniciante é capaz de reconhecer a correção das atividades como uma prática dos professores, mas ele tem que aprender como desempenhar essa tarefa. Esse processo de aprendizagem, de reconcepção da tarefa, não ocorre sem dificuldades, já que identificamos a insatisfação no trabalho desse professor que ainda não se apropriou do gênero profissional. Diante disso, acreditamos ser fundamental a presença do coletivo de trabalho, pois nele é possível confrontar as diferentes maneiras de fazer, trocar experiências, debater e questionar o próprio trabalho (CLOT, 2013). Isso nos mostra a importância de ter instâncias que assegurem o trabalho do professor que formem de fato um coletivo de professores que poderá atuar de maneira conjunta na integração de novos membros.

Além disso, podemos imaginar que a possibilidade de intervenção na situação de trabalho, por meio da IS, pode trazer um contato com maneiras de fazer que o professor iniciante não necessariamente internalizou. Nesse sentido, ao possibilitar a tomada de consciência, a IS pode ser considerada um interessante método na formação de professores iniciantes.

Como dissemos, para compensar a falta de "formas de fazer mais ou menos difundidas na profissão" (FAÏTA, 2004, p.64), o professor iniciante utiliza recursos 
intermediários como técnicas de controle da sala de aula, assim como já ressaltados por Saujat (2004) e Félix e Saujat (2007). No caso do professor iniciante de FLE, essas técnicas aparecem centradas na organização do contexto de trabalho, como por exemplo, do material para o trabalho (lousa, ficha preparada para o professor não "se perder" na aula), do calendário, dos conteúdos linguísticos, das atividades desenvolvidas em sala (divisão dos alunos para atividades em grupos) etc. O professor iniciante de FLE, para estar no controle, utiliza regras e técnicas, como combinadas e acordadas com os alunos, para que a situação de ensino-aprendizagem não fuja de seu controle, pois algumas situações podem contribuir para desestabilizar o ambiente seguro construído por ele mesmo. Os alunos que questionam demais nas aulas, por exemplo, podem representar uma ameaça para esse professor, já que se perguntarem sobre coisas diferentes do que está sendo ensinado, a aula pode "tomar outro rumo", ou ainda, o professor pode não saber aquilo que não estava programado. Para evitar que isso aconteça, nossa professora iniciante tentou assumir uma postura autoritária em sala de aula, construindo uma barreira entre ela e seus alunos. Ao mencionar essa possibilidade, não estamos apontando que essa é uma atitude a adotar: estamos apenas constatando que se trata de uma maneira de fazer que foi adotada por uma professora iniciante e que pode ser adotada por outros professores. Para evitar que isso aconteça, a instituição pode propor alternativas, sendo que a primeira poderia ser um diálogo aberto sobre as ideias que permeiam a formação de novos professores.

Outro obstáculo destacado no trabalho do professor iniciante de FLE é a falta de experiências anteriores. Assim, para compreender as dificuldades de seus alunos, uma das soluções encontrada pelo iniciante é de se colocar na posição de aluno, já que é a sua referência mais próxima de ensino-aprendizagem, para refletir sobre como ele aprendeu o mesmo conteúdo. Essa estratégia pode ser positiva, pois a comparação (como aprendeu e como seus alunos aprendem) é usada como uma tática de ensino, que procura ensinar da forma como achou mais fácil aprender. Ao mesmo tempo, essa prática pode ser limitada, já que apenas a experiência do professor como aluno não soluciona todos os problemas, principalmente os que estão diretamente ligados à prática docente.

Diante desses problemas, o professor busca recursos para criar um ambiente agradável em seu trabalho. O intervalo, por exemplo, aparece como um momento para relaxar, para estar junto de colegas mais próximos, conversar sobre outros assuntos, contribuindo com trocas na situação de trabalho e com a redução dos efeitos de fadiga 
mental e/ou física (NOUROUDINE, 2002). Essas estratégias podem aparecer como uma autoprescrição para o trabalho, pois acreditamos, baseados em Clot (2003) e Saujat (2007), que quanto mais o professor reconhecer-se em seu trabalho, mais preservada será sua saúde, de forma geral, nesse contexto. Nesse sentido, é fundamental que haja espaço para a elaboração das autoprescrições dos professores, compostas a partir das prescrições gerais sobre seu trabalho, pois é a partir delas que o professor constrói sua competência, saúde, sua identidade (SAUJAT, 2002).

Por fim, podemos dizer que, para o professor iniciante de FLE, é importante dominar os conteúdos linguísticos da LE, confirmando que o trabalho do professor vai além das atividades desenvolvidas em sala de aula com os alunos (AMIGUES, 2004), controlar os diferentes tipos de organização que o ensino de FLE demanda e autoprescrever tarefas que preservam a sua saúde no trabalho.

Conforme apresentamos até agora, nossa pesquisa revelou importantes considerações sobre o trabalho de ensinar uma língua estrangeira. Vejamos, agora, algumas das limitações desta pesquisa.

Para tanto, é necessário retomar como desenvolvemos o procedimento de instrução ao sósia (IS), assim como procedemos na análise desse procedimento. Nossa entrevista de IS não foi gerada tal como proposto por Clot (1999), no que diz respeito ao papel do pesquisador. Enquanto esse autor indica que o pesquisador desempenha a função de sósia (CLOT, 2001), em nossas entrevistas, a pesquisadora não corresponde ao sósia, mas a uma das professoras-instrutoras. Esse modo de configuração das entrevistas está ligado à constituição do nosso coletivo que, formado por duas professoras iniciantes (eu e Mariana) e uma professora mais experiente (Flávia), se propôs a uma geração única de dados para duas pesquisas sobre o trabalho do professor iniciante de FLE (a presente pesquisa e a de Mariana). Sendo assim, nós duas fomos as instrutoras e Flávia a sósia das entrevistas de IS.

No que diz respeito à análise dos dados, consideramos que, na perspectiva por nós adotada, focaliza-se na análise da situação de trabalho vivida por outros. Assim, nosso estudo se concentrou na análise das instruções de Mariana à sósia e das discussões que sugiram sobre sua atividade e sobre o seu contexto de trabalho tanto nas IS, quanto nos retornos às IS. Dessa forma, pensamos que o modo de configuração do procedimento das entrevistas de IS pode suscitar questionamentos, já que estamos diretamente implicadas na situação de geração de dados. No entanto, julgamos que isso não é um verdadeiro 
problema para a pesquisa, pois, considerando somente os dados ligados ao contexto de Mariana, buscamos um distanciamento que nos possibilitou analisá-los com propriedade. Além disso, podemos considerar a própria situação de geração única de dados como um fator inovador para as pesquisas e que pode, inclusive, suscitar futuramente uma comparação entre os dados gerados para ambas as pesquisas.

Outra limitação diz respeito às discussões desenvolvidas nas IS e nos retornos, já que algumas questões não foram apresentadas nos resultados das análises pelo fato de estarem muito atreladas ao meu contexto de trabalho. Ao propormos não analisar as IS e os seus retornos na íntegra, para manter o distanciamento, inevitavelmente, deixamos de lado algumas confrontações e trocas de experiências entre duas professoras de diferentes contextos de trabalho. Porém, esses dados ficam disponíveis, como dissemos, para futuros estudos que possam comparar o trabalho de duas professoras iniciantes em contextos diferentes.

Por outro lado, nosso estudo contribui com o conjunto de pesquisas já desenvolvidas pelo grupo ALTER-AGE-CNPq, no contexto dos cursos Extracurriculares de francês da FFLCH-USP (GUIMARAES-SANTOS, 2012; DANTAS-LONGHI, 2013; MELAO, 2014; ANEZ-OLIVEIRA, 2014; ROCHA, 2014; SILVA, 2015; MENEZES, 2015) e também para o Grupo ALTER-CNPq. Podemos apontar dois diferenciais desta pesquisa em relação às do nosso grupo. O primeiro diz respeito ao olhar mais aprofundado sobre o trabalho de uma professora que é iniciante de FLE dos cursos Extracurriculares de francês, o que é fundamental para compreender esse contexto de trabalho, já que Dantas-Longhi (2013) afirma que muitos professores iniciam suas atividades nesses cursos. Dessa forma, nossos dados podem contribuir com futuras pesquisas nesse mesmo ambiente de trabalho. O segundo diferencial é o uso dos diários de aula, ao lado das entrevistas de IS, como ferramenta para reflexão da atividade de ensino (LIBERALI, 1999), algo que ainda não havia sido desenvolvido em nosso grupo. Assim, nesta pesquisa, propomos uma reflexão sobre o papel de duas ferramentas na formação inicial de professores: o método de intervenção "instrução ao sósia", visto que a IS é um método que permite a intervenção na situação de trabalho, pois o professor pode tomar consciência de algo que não estava claro para si, desenvolvendo outras maneiras de agir, após reviver a experiência vivida (CLOT, 2008), e os diários de aulas, que, segundo o estudo de Liberali (1999) à luz de pesquisadores pertencentes a outras linhas teóricas, 
como Stover (1986), são um meio para, não apenas examinar o conhecimento do professor, mas gerar o conhecimento desse professor.

Finalmente, cabe refletir sobre o papel deste estudo para a professora participante da pesquisa, para a própria pesquisadora e para a sósia. Acreditamos que o fato de Mariana ter podido refletir sobre seu trabalho nas IS e nos diários contribuiu para sua aprendizagem do trabalho de ensinar, pois ambos permitiram que ela tivesse um olhar distanciado sobre seu trabalho o que, nos dizeres de Clot (2008), pode aumentar seu poder de agir. É nessa perspectiva que os pesquisadores da Clínica da Atividade e da Ergonomia da Atividade falam do caráter transformador ou formativo do método da Instrução ao Sósia. Embora reconheçamos que a transformação do professor não é de maneira alguma automática, para Clot (2001), a situação na qual o sujeito vê sua experiência com um outro ponto de vista, já pode ser considerada como uma transformação da atividade. Nesse sentido, em uma pesquisa futura, seria pertinente analisar a primeira e a última IS, por exemplo, procurando ver se houve mudanças entre uma e outra. Ou, ainda, realizar outra IS com as mesmas professoras e pesquisadoras, para poder ter registros do que elas fizeram do que disseram nas duas primeiras IS.

Acreditamos, enfim, que esta pesquisa contribuiu para o desenvolvimento em geral das três participantes: Mariana, no que diz respeito ao seu trabalho como professora; Flávia, no que diz respeito à intervenção em contexto de trabalho; e meu, enquanto pesquisadora sobre o trabalho do professor iniciante. 


\section{REFERÊNCIAS BIBLIOGRÁFICAS}

ABREU-TARDELLI, L. S. trabalhodoprofessor@chateducacional.com.br- Aportes para compreender o trabalho do professor iniciante em EAD. Tese (Doutorado em Linguística Aplicada e Estudos da Linguagem) - Pontifícia Universidade Católica de São Paulo, São Paulo, 2006.

AMIGUES, R. L'enseignement comme travail. In P. Bressoux (Ed.). Les stratégies d'enseignement en situation d'interaction. Note de synthèse pour Cognitique : Programme Ecole et Sciences Cognitives, pp. 243-262, 2002.

série 1, 5-16, 2003.

Pour une approche ergonomique de l'activité enseignante. Skholê, hors-

. Trabalho do professor e trabalho de ensino. In: MACHADO, A. R. $O$ ensino como trabalho: uma abordagem discursiva. Londrina : Eduel, p. 35-54, 2004.

Le travail enseignant: prescriptions et dimensions collectives de l'activité. Les Sciences de l'éducation - Pour l'ère nouvelle, v. 42, n. 1, p.11-26, 2009. Disponível em <http://www.cairn.info/zen.php?ID_ARTICLE=LSDLE_422_0011>. Acesso em 09/10/2014.

. Vygotski: a consciência como relação. Tradução de Maria Amália Barjas Ramos. Psicologia \& Sociedade, 26(n. spe. 2), 124-139, 2014. Disponível em: < http://www.scielo.br/pdf/psoc/v26nspe2/a13v26nspe2.pdf>. Acesso em 24/01/2016.

. Pour une approche ergonomique de l'activité enseignante. In:

FAÏTA, D.; KHERROUBI, M. (ed.). Métier enseignant, organisation du travail et analyse de l'activité. Marseille. Skholê, 2013, hors série 1, p. 5-16.

AMIGUES R.; FAITA D.; KHERROUBI M. Métier d'enseignant: organisation du travail et analyse de l'activité. SKHOLE, 2003, hors série 1.

AMIGUES, R. ; FÉLIX, C.; ESPINASSY, L. Observer le travail enseignant. Recherche en Éducation, 2014. Disponível em <http://www.recherches-eneducation.net/IMG/pdf/REE-no19.pdf >. Acesso em 28/10/2014.

AÑEZ-OLIVEIRA, R. O fait divers no ensino: influências da sequência didática nas produções escritas de alunos de FLE. 2014. Dissertação (Mestrado em LETRAS) Faculdade de Filosofia, Letras e Ciências Humanas. Universidade de São Paulo. Universidade de São Paulo, 2014.

AUTHIER-REVUZ, J. As não-coincidências do dizer e sua representação metaenunciativa - estudo linguístico e discursivo da modalização autonímica. Palavras incertas - As não coincidências do dizer. Campinas, SP: Editora da UNICAMP, 1998.

BARRICELLI, E. Transformações e conflitos no processo de elaboração, de difusão e de utilização de instruções oficiais de Educação Infantil: um estudo genealógico. 2012. Tese (Doutorado em linguística aplicada e estudos da linguagem). Pontifícia Universidade Católica de São Paulo. 
BATISTA, M. A.; RABELO, L. B. C. Imagine que eu sou seu sósia. Aspectos técnicos de um método em clínica da atividade. Cadernos de Psicologia Social do Trabalho (USP), 2013, v. 16, p. 1-8.

BAZET, I. Le plan ou la prescription de l'engagement. In: Congrès de la SELF, 37, 2002, Provence. Actes... Provence, 2002. p.162-167.

BERTHET M. ; CRU D. Travail prescrit, travail réel et santé au travail, De nouveaux modes d'intervention ergonomique? in Travail et Emploi, $\mathrm{n}^{\circ}$ 96, octobre 2003, pp. 8596.

BOURDET, J.-F.; TEUTSCH P. Réseaux sociaux en ligne et espace distancié d'apprentissage - Quelle transférabilité ? Alsic [En ligne], Vol. 15, $\mathrm{n}^{\circ} 2 \mid 2012$, mis en ligne le 25 juin 2012, Consulté le 12 mai 2014. URL : http://alsic.revues.org/2500; DOI: $10.4000 /$ alsic. 2500 .

BRONCKART, J.-P. (1999). Atividade de linguagem, textos e discursos: por um interacionismo sócio-discursivo. São Paulo: EDUC, 2009.

BRONCKART, Jean-Paul. Pourquoi et comment analyser le travail de l'enseignant(e). In: Il mestiere del'insegnante. Analisi dell'azione docente. Aoste : Assessorato all'Istruzione e Cultura, 2004. p. 9-35.

Les différentes facettes de l'interactionnisme socio-discursif. Calidoscópio. Vol. 3 , n. 3 , p. 149-159, set/dez 2005.

Atividade de linguagem, discurso e desenvolvimento humano. Campinas: Mercado de Letras, 2006.

O agir nos discursos. Das concepções teóricas às concepções dos trabalhadores. Campinas: Mercado de Letras, 2008.

Gêneros de textos, tipos de discurso e sequências. Por uma renovação do ensino

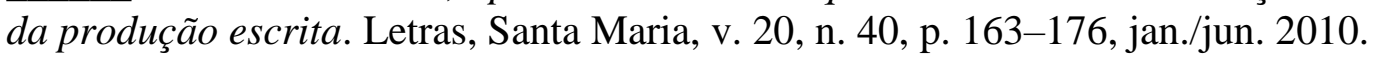

Evolutions récentes de la conception et du statut des genres textuels dans la perspective de l'ISD. Genève, Université de Genève, 2013. Notes de présentation de la Conférence Activités, textes et langues: leur dymanique interactive et ses effets.

Vygotsky, une oeuvre en devenir - In : SCHNEUWLY B. \& BRONCKART J.P. (Ed.), Vygotsky aujourd'hui, Paris, Delachaux \& Niestlé, 1985, 7-21.

BRONCKART, J.-P. \& Groupe LAF (Ed.). Agir et discours en situation de travail. Genève : Université de Genève, 2004. (Cahiers de la Section des sciences de l'Education, $\left.\mathrm{n}^{\mathrm{o}} 103\right)$.

BRONCKART, J.-P.; MACHADO, A. R. Procedimentos de análise de textos sobre o trabalho educacional. In: MACHADO, A. R. (Org.) $O$ ensino como trabalho - Uma abordagem discursiva. Londrina: Eduel, 2004.

BUENO, L. A construção de representações sobre o trabalho docente: o papel do estágio. Tese (Doutorado em Linguística Aplicada e estudos da linguagem). Pontifícia Universidade Católica de São Paulo, São Paulo, 2007. 
BULEA, E. Linguagem e efeitos desenvolvimentais da interpretação da atividade. Tradução de Eulália Vera Fraga Leurquin e Lena Lúcia Espínola Rodrigues Figueirêdo. Campinas: Mercado de Letras, 2010.

BULEA, E.; FRISTALON, I. Agir, agentivité et temporalité dasn des entretiens sur le travail infirmier. In : BRONCKART, J.P. e al. Agir et discours en situation de travail. Cahier nº 103. Genebra, 2004.

Bulea, E. ; Bronckart, J.-P. Les conditions d'exploitation de l'analyse des pratiques pour la formation des enseignants. Linguarum Arena. Revista do Programa Doutoral em Didáctica de Línguas da Universidade do Porto, 2010, vol. 1, n 1, 43-60.

BUZZO, M. G. Os professores diante um novo trabalho com a leitura: modos de fazer semelhantes ou diferentes? São Paulo: 2008.

CHAMBEL, M. J. O stress na profissão professor. IN : Proformar, 2005. Disponível em : http://proformar.pt/revista/edicao_7/pag_2.htm . Acesso em 24/10/2014.

CLOT, Y. La fonction psychologique du travail. Paris: Presses Universitaires de France, 1999.

. Méthodologie en clinique de l'activité: l'exemple du sosie. In: DELEFOSSE, M. S.; ROUAN, G. (Orgs.). Les méthodes qualitatives en psychologie. Paris: Dunod, 2001.

. A função psicológica do trabalho. (2 ${ }^{\mathrm{a}}$ ed.). Petrópolis, RJ. Vozes, 2007.

$\begin{array}{llll}\text {. De l'analyse des pratiques au développement des métiers. Éducation et } \\ \text { didactique, } \quad \text { vol } 1 \quad-\quad \mathrm{n}^{\circ} 1 \mid \text { avril } & 2007 \text {. Disponível em < }\end{array}$ http://educationdidactique.revues.org/106>. Acesso em: 24/01/2016.

. Travail et pouvoir d'agir, Paris : PUF, 2008.

O ofício como Operador de Saúde. Cadernos de Psicologia Social do Trabalho, São Paulo, v.16, n. especial, p.1-11, 2013.

Vygotski: a consciência como relação. Psicologia \& Sociedade, 2014. Trad. M. A. B. Ramos, 26(n. spe. 2), 124-139.

CLOT, Y. ; PROT, B. ; WERTHE, C. Clinique de l'activité et pouvoir d'agir. Éducation permanente, 2001, n ${ }^{\circ} 146,12-37$.

CLOT, Y. (dir.). Vygotski maintenant, Paris, La Dispute, 2012, 414 p.

CLOT, Y. ; FAÏTA, D. Genre et style en analyse du travail, concepts et méthodes. In: Travailler, n. 4, p. 7-42, 2000.

CLOT, Y. et al. Entretiens en autoconfrontation croisée: une méthode en clinique de l'activité. Pistes, v. 1, n. 1, p. 1-7, 2000. Disponível em: http://pistes.revues.org/3833. Acesso em: 24/01/2016.

CLOT, Y, FAÏTA, D. et al. Entretiens en auto-confrontation croisée: une méthode en clinique de l'activité. In : Clinique de l'activité et pouvoir d'agir. Paris, Education Permanente, 2001, n. 146, p. 17-25. 
CLOT, Y.; YVON, F. Apprentissage et développement dans l'analyse du travail enseignant. Psicologia da Educação, 2004, p. 11-38.

Clot, Y. \& Leplat, J. La méthode clinique en ergonomie et en psychologie du travail. Le Travail Humain, 2005, 4 (68), p. 289-316.

CONSEIL DE L'EUROPE. Cadre européen commun de référence pour les langues : Apprendre, Enseigner, Évaluer (CECRL), 2001. Disponível em <http://www.coe.int/t/dg4/linguistic/Source/Framework_fr.pdf>. Acesso em $31 \mathrm{de}$ outubro de 2014.

DAGUZON, M.; GOIGOUX, R. L'influence de la prescription adressée aux professeurs des écoles en formation initiale : construction d'un idéal pédagogique. In: Actualité de la Recherche en Education et en Formation. Strasbourg, 2007.

DANIELLOU, F. Le travail des prescriptions. In Actes du 37ième Congrès de la SELF Nouvelles formes de travail, nouvelles formes d'analyse, Aix en Provence, 2002, pp 916.

DANTAS-LONGHI, S. M. Como os jogos podem revelar outras dimensões do trabalho do professor de língua estrangeira?. 2013. Dissertação (Mestrado em Língua e Literatura Francesa) - Faculdade de Filosofia, Letras e Ciências Humanas, Universidade de São Paulo, São Paulo, 2013. Disponível em: http://www.teses.usp.br/teses/disponiveis/8/8146/tde-30072013-103516/. Acesso em: 2014-10-31.

ENGELS, Friedrich. Sobre o papel do trabalho na transformação do macaco em homem (1876). São Paulo: Rocketedition, 1999.

FAÏTA, D. Análise das práticas linguageiras e situações de trabalho: uma renovação metodológica imposta pelo objeto. In: SOUZA-E-SILVA, M. C. P.; FAÏTA, D. (Org.). Linguagem e trabalho: construção de objetos de análise no Brasil e na França. São Paulo: Cortez, 2002.

Gêneros de discurso, gêneros de atividade, análise da atividade do professor. In: Machado, A. R. (Org.) O ensino como trabalho: uma abordagem discursiva. Londrina: Eduel, 2004, p. 53-80.

FAÏTA, D.; SAUJAT, F. Développer l'activité des enseignants pour comprendre et transformer leur travail : un cadre théorique et méthodologique. In : SAUSSEZ, F \& F. YVON, F. (Eds.) Analyser l'activité enseignante : des outils méthodologiques et théoriques pour l'intervention et la formation. Québec, Presses de l'Université de Laval, 2010, p.41-69.

FAÏTA, D.; VIEIRA, M. Réflexions méthodologiques sur l'autoconfrontation croisée. DELTA: Documentação de Estudos em Lingüística Teórica e Aplicada, 2003, v. 19, p. 123-154.

Félix C. \& Saujat F. (2007) Les débuts dans le métier d'enseignant - Congrès international AREF 2007, Actualité de recherche en éducation et formation. Université Louis Pasteur. Strasbourg, 2007. Actes consultables en ligne : http://www.congresintaref.org/actes_site.php (acesso em 22/01/2016). 
FRIEDRICH, J. Lev Vygotski: médiation, apprentissage et développement: une lecture philosophique et épistémologique. Genève: Université de Genève, 2010. (Carnets des Sciences de 1'Éducation).

GOIGOUX, R. L'évolution de la prescription adressée aux instituteurs : l'exemple de l'enseignement de la lecture entre 1972 et 2002. In: EVESQUE, J.-M.; GAUTIER, A.M. ; REVEST, C. ; et SCHWARTZ, Y. (Eds.) Les évolutions de la prescription. Actes du XXXVIIème congrès de la Société d'Ergonomie de Langue Française. Aix-en-Provence: GREACT, 2002, p. 77-84.

GUARNIERI, Maria Regina (org.). Aprendendo a Ensinar - O Caminho Nada Suave da Docência. 2. ed. São Paulo: Autores Associados, 2005.

GUIMARÃES, A. M de M. O agir educacional nas representações de professores de língua materna. In: GUIMARÃES, A. M., MACHADO, A. R. \& COUTINHO, A. (orgs.). O Interacionismo sociodiscursivo: questões epistemológicas e metodológicas. Campinas: Mercado de Letras, 2007.

GUIMARÃES-SANTOS, L. O gênero itinéraire de voyage para pensar o agir social no ensino-aprendizagem do FLE. Dissertação (Mestrado) Faculdade de Filosofia, Letras e Ciências Humanas. Universidade de São Paulo. Universidade de São Paulo, 2012.

HUBERMAN, M. O ciclo de vida profissional dos professores. In: NÓVOA, António (Org.) Vidas de professores. Lisboa: Porto Editora, 1992. p. 31-61.

KONDER, L. Marx: vida e obra. São Paulo: Paz e Terra, 1999.

LAVILLE, A. Repères pour une histoire de l'ergonomie francophone. In : Comptes rendus du Congrès SELF-ACE 2001 - Les transformations du travail, enjeux pour l'ergonomie. Disponível em <http://www.ergonomie-self.org/documents/36emeMontreal-2001/PDF-FR/v1-01a-laville.pdf >. Acesso em 31/10/2014.

LIBERALI, F. C. O diário como ferramenta para a reflexão crítica. Tese (Doutorado em Lingüística Aplicada) - LAEL, Pontifícia Universidade Católica de São Paulo - PUC, São Paulo, 1999.

LOUSADA, E. G. Os pequenos grandes impedimentos da ação do professor: entre tentativas e decepções. In: MACHADO, A. R. (Org.) $O$ ensino como trabalho: uma abordagem discursiva. Londrina: Eduel, 2004 v.1. p. 271-296.

Entre o trabalho prescrito e o realizado: um espaço para a emergência do trabalho real do professor. Tese (Doutorado em Linguística Aplicada e Estudos da Linguagem) - Pontifícia Universidade Católica de São Paulo, São Paulo, 2006.

A abordagem do interacionismo sociodiscursivo para a análise de textos. In: II EPED - Abordagens metodológicas em estudos discursivos. São Paulo: Editora Paulistana, 2010. p. 11-26.

LOUSADA, E. G.; BARRICELLI, E. Análise comparativa de textos que orientam o trabalho educacional: décadas diferentes, mesmas prescrições. Eutomia (Recife), v. 1, p. 224- 246, 2011. 
. Gêneros textuais e ensino do francês como língua estrangeira. Bauru: USC, 2011. (Comunicação oral).

. Textos na formação inicial de professores: o caso do relatório de estágio. In: BUENO, L.; LOPES, M. A. P. T.; CRISTOVÃO, V. L. L. (Org.). Gêneros textuais e formação inicial. 1ed. Campinas: Mercado de Letras, 2013, v. 1, p. 133-152.

LOUSADA, E. G.; DANTAS-LONGHI, S. M. Vozes em confronto: o papel das entrevistas de confrontação no desenvolvimento do professor e de sua atividade de trabalho. In: Elivra Lopes Nascimento; Roxane Helena Rodrigues Rojo. (Org.). Gêneros de texto/discurso e desafios da contemporaneidade. 1ed. Campinas: Pontes, 2014, v. 1, p. 143-166.

LURIA, A. R. A atividade consciente do homem e suas raízes histórico-sociais. In: Curso de Psicologia Geral: Introdução Evolucionista à Psicologia. Rio de Janeiro: Civilização Brasileira, 1991. Vol.I, p.71-84.

MACHADO, A. R. O diário de leituras: introdução de um novo instrumento na escola. São Paulo: Martins Fontes, 1998.

Por uma concepção ampliada do trabalho do professor. In: GUIMARÃES, A. M. de M.; MACHADO, A. R.; COUTINHO, A. (Orgs.). O Interacionismo sociodiscursivo: questões epistemológicas e metodológicas. Campinas: Mercado de Letras, 2007.

MACHADO, A. R. et al. Relações entre linguagem e trabalho educacional: novas perspectivas e métodos no quadro do interacionismo sociodiscursivo. In: CRISTOVÃO, Vera Lúcia; ABREU-TARDELLI, Lília S. (Org.). Linguagem e educação: o trabalho do professor em uma nova perspectiva. Campinas: Mercado das Letras, 2009.

MAINGUENEAU, D. Análise de textos de comunicação. Tradução de Cecília P. de Souza-e-Silva e Décio Rocha. 6ª ed. São Paulo: Cortez, 2011.

MARCUSCHI, L. A Análise da Conversação. $5^{\mathrm{a}}$ ed. São Paulo: Ática, 2001.

MARX, K. O Capital. Volume $1-$ capítulo 7. 1867. Disponível em 〈https://www.marxists.org/portugues/marx/1867/ocapital-v1/vol1cap07.htm>. Acesso em: 24/01/2016.

MAZZILLO, T. O diário do professor-aluno: um instrumento para a avaliação do agir. In: MACHADO, A. R. (org.) O ensino como trabalho: Uma abordagem discursiva. Londrina: Eduel, 2004. p. 297-325.

MELÃO, P. A. O gênero textual anúncio publicitário no ensino do FLE: o desenvolvimento da capacidade de argumentação por meio de recursos verbais e visuais. 2014. Dissertação (Mestrado) Faculdade de Filosofia, Letras e Ciências Humanas. Universidade de São Paulo. Universidade de São Paulo, 2014.

NASCIMENTO, E. L. A dupla semiotização dos objetos de ensino-aprendizagem: dos gestos didáticos fundadores aos gestos didáticos específicos. Signum. Estudos da Linguagem. Revista do Programa de Pós-graduação em estudos da Linguagem. Universidade Estadual de Londrina, 2011. 
NEBOIT, M. Histoire de l'ergonomie. Disponível em < http://www.preventica.com/docs/self- 07-06.pdf>. Acesso em 24/01/2016.

NOUROUDINE, A. A linguagem: dispositivo revelador da complexidade no trabalho. In: FAÏTA, D.; SOUZA-E-SILVA, M. C. P. (Coord.) Linguagem e trabalho: construção de objetos de análise no Brasil e na França. 1 ed. São Paulo: Cortez, 2002.

PEREIRA, R. C. M. Gêneros textuais e letramento: uma abordagem sociointeracionista da produção escrita de crianças de $1^{a}$ e $2^{a}$ séries. Recife, PE. Tese de Doutorado. Universidade Federal de Pernambuco - UFPE, 2005, 265 p.

ROCHA, S. M. Coerções e liberdades textuais em francês como língua estrangeira: por um desenvolvimento do estilo na produção escrita por meio do gênero textual relato de viagem. Dissertação (Mestrado) - Universidade de São Paulo, 2014.

SAUJAT, F. Co-analyse de l'activité enseignante et développement de l'expérience: du travail de chacun au travail de tous et retour. In: Clinique de l'activité et pouvoir d'agir, Paris, n. 146, p. 87-98, 2001.

Systèmes d'apprentissage: systèmes d'évaluation. 2002. Thèse (Doctorat) - Université de Provence, Provence, 2002.

. Comment les enseignants débutants entrent dans le métier. In: Formation et pratiques d'enseignement en questions, 2004, p. 97-106.

. O trabalho do professor nas pesquisas em educação: Um panorama. In:

MACHADO, A. R. (org.). O ensino como trabalho - Uma abordagem discursiva. Londrina: Eduel, 2004b.

01-07.

Fonction et usages de l'instruction au sosie en formation initiale, 2005, p.

. Enseigner : un travail. In V. Dupriez et G. Chapelle (Eds.). Enseigner. Paris: PUF, 2007, p. 179-188.

SCHNETZLER, R. P. Concepções e alertas sobre formação continuada de professores de Química. Química Nova na Escola, n. 16, p. 15-20, 2002.

SCHNEUWLY, B; DOLZ, J. Des objets enseignés en classe de français. Rennes: Presses Universitaires de Rennes, 2010.

SILVA, E. C. O vivido, o revivido e os possíveis do desenvolvimento em diálogo: um estudo sobre o trabalho do professor de FLE com os conteúdos culturais. Dissertação (Mestrado) Faculdade de Filosofia, Letras e Ciências Humanas. Universidade de São Paulo. 2015.

SOUZA-E-SILVA, M. C. P. A dimensão linguageira em situações de trabalho. In: ; FAÏTA, D. (Org.). Linguagem e trabalho: construções de objetos de análise no Brasil e na França. São Paulo: Cortez, 2002. p. 61-76.

VYGOTSKI, L. S. (1934). Pensée et Langage. Paris: La Dispute, 1997.

La signification historique de la crise en psychologie. Lausanne, Paris : Delachaux et Niestlé, 1927/1999. 
Psicologia Pedagógica. Edição Comentada. Porto Alegre: Artmed, 2003.

. A construção do pensamento e da linguagem. São Paulo: Martins Fontes, 2009. 


\section{Entrevista com Marli André}

\section{"A equipe gestora deve acolher e ajudar o professor iniciante"}

Bruna Nicolielo

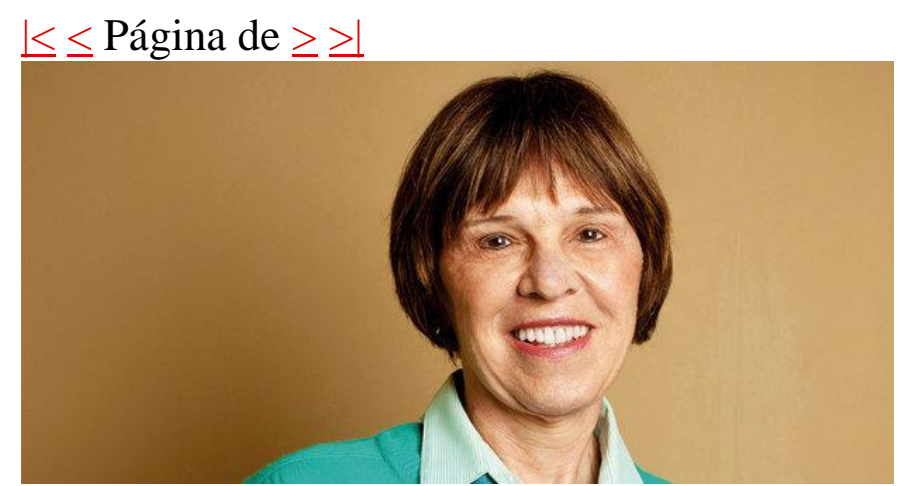

Marli André Docente da Pontifícia Universidade Católica de São Paulo (PUC-SP) e Ph.D. em Psicologia da Educação pela Universidade de Illinois, nos Estados Unidos, se dedica à área de formação de professores há 30 anos

Todos os anos, milhares de jovens entram pela primeira vez em uma sala de aula para lecionar. Eles chegam com disposição e vontade, mas carregam indagações e inseguranças e sabem que enfrentarão enormes desafios, envolvendo a realidade escolar e a relação com os estudantes, as famílias e a própria escola. Por sua vez, a instituição nem sempre assegura a integração e o aprimoramento do professor novato, segundo a pesquisadora Marli André. Na opinião dela, os gestores têm de investir mais na troca de experiências entre os iniciantes e os veteranos. Assim, todos saem ganhando, especialmente os alunos.

\section{O que defne um professor iniciante?}

MARLI ANDRÉ Não há consenso sobre isso. Muitos autores se baseiam no tempo de docência e defendem que os três primeiros anos são considerados os mais difíceis para quem está começando. Segundo eles, essa é a razão de existir um estágio probatório, descrito na literatura como os "anos de sobrevivência", período em que o jovem tenta permanecer na profissão. Levando isso em conta, podemos dizer que o desafio do novato é se equilibrar entre deixar de ser aluno e começar a ser professor, aprendendo a ensinar.

\section{Qual é o perfl dos iniciantes no Brasil?}


MARLI Em geral, eles fazem parte das camadas menos favorecidas da população e optam pela docência influenciados pelos pais ou por algum parente, que é ou foi educador. São os primeiros membros da família a alcançar o Ensino Superior e julgam o Magistério uma opção segura, que sempre tem postos de trabalho disponíveis.

\section{Quais as maiores frustrações de quem está no início de carreira?}

MARLI Elas são muitas. A maior delas é não ter clareza da função social da escola e de si mesmo como educador. Esse profissional acha que precisa não só fazer os estudantes aprenderem mas também apoiá-los e ouvir e entender os problemas pessoais deles. Isso tudo ao mesmo tempo que, muitas vezes, os alunos não querem estar em sala, sobretudo os mais velhos. Ele acredita que precisa desempenhar muitos papéis e que não tem formação para tal. Reclama que assume a função de pai e psicólogo e diz que não tirou o diploma para ficar ouvindo a meninada. É professor e está na escola para ensinar. Outra frustração tem a ver com a pouca participação da família. Quem está começando espera muito dos pais das crianças e dos jovens. Quer que eles ajudem na lição de casa, verifiquem o que o filho está aprendendo e fica desapontado quando nota que isso não ocorre.

\section{A quem o jovem docente costuma recorrer para pedir orientações?}

MARLI Em geral, por iniciativa própria, ele busca apoio de um colega mais experiente da escola em que trabalha ou de outra instituição. A equipe gestora deve acolher e ajudar o professor iniciante. Mas isso não acontece nas redes de modo formal e com a frequência desejável.

\section{O que pode ser feito nas escolas para assegurar a troca de experiências?}

MARLI Elas precisam institucionalizar essa prática. É possível criar grupos de tutoria nos quais cada jovem educador passa a receber a orientação de um colega que tem mais tempo de docência. Outra possibilidade é organizar periodicamente reuniões para que seja realizada a discussão da prática de sala de aula. Assim, quem está na profissão há mais tempo pode relatar experiências de sucessos e expor seu ponto de vista.

\section{Qual a imagem que a equipe escolar costuma fazer do jovem professor?}

MARLI Ele geralmente não é visto pelos colegas que têm mais tempo de carreira como o aprendiz que de fato é, alguém que precisa de apoio e estímulo. A maioria o julga um profissional idealista. Os pais da criançada também não se sentem seguros diante de um educador muito jovem. Ele, por sua vez, encara os colegas como pessoas acomodadas, que não são inovadoras. 


\section{Do que depende a atração e a retenção dos melhores profssionais nas salas de aula?}

MARLI O salário é importante para chamar a atenção e manter bons professores, mas não é suficiente. Vários levantamentos tentam relacionar a remuneração ao desempenho docente, mas não conseguem. Há outras condições fundamentais para garantir a atratividade, como a melhoria da formação inicial e a existência de planos de carreira estruturados. Também é essencial um bom ambiente de trabalho na escola e isso diz respeito a muitas coisas: infraestrutura, relações entre a equipe e a comunidade e ainda meios de que a instituição dispõe para valorizar e ajudar o corpo docente - por exemplo, assessoria relacionada às dúvidas e às necessidades em relação aos estudantes e aos conteúdos a ser ensinados. Sobre a permanência do bom profissional, há outro fator relevante, segundo pesquisas: ter sucesso no processo de ensino e de aprendizagem. Prova disso é ser comum encontrar novatos dizendo: "Mesmo com todos os problemas que enfrento, ver o brilho nos olhos dos alunos quando eles aprendem é o que me faz continuar lecionando".

Quais as descobertas de sua pesquisa mais recente, ainda em curso, sobre a aproximação das universidades com a escola na formação de professores? MARLI Os dados obtidos até agora revelam coisas boas para o futuro da docência no país. Vamos ter profissionais mais bem formados por causa do Programa Institucional de Bolsa de Iniciação à Docência (Pibid), pois a proposta dele, já em prática, é inserir o novato na escola pública por meio de um estágio. Nas cinco instituições universitárias em que estou fazendo o estudo, os graduandos têm experiências positivas: são bem acompanhados na escola por um educador experiente, que desempenha o papel de tutor, e recebem muitas informações sobre como atuar em sala de aula. Eles são unânimes em dizer que estão aprendendo como fazer a articulação da teoria com a prática, dando um novo significado ao que estudam na faculdade.

\section{O Pibid também altera o cenário de atratividade da docência?}

MARLI Sim. Quando perguntamos aos bolsistas se eles querem se dedicar ao Magistério depois dessa experiência, a maioria responde de forma afirmativa. Em minha pesquisa anterior (O Papel das Práticas de Licenciatura na Constituição da Identidade Profissional de Futuros Professores), realizada antes do Pibid, identifiquei que os estagiários tinham grandes dúvidas sobre permanecer ou não na carreira. O programa está até atraindo os jovens que não tinham o ensino como primeira opção profissional. Eles dizem: "Nunca pensei em ser professor, mas, depois que comecei a participar desse programa, eu quero!". 


\section{As instituições de Ensino Superior também estão sendo impactadas pelo}

\section{programa?}

MARLI Sim. Os futuros docentes estão exigindo mais da estrutura universitária. Quem leciona relata que os estudantes dão trabalho: eles perguntam muito e querem mais materiais para estudar. Ou seja, o Pibid está proporcionando a formação continuada dos docentes do Ensino Superior, porque eles precisam se atualizar cada vez mais para atender os alunos. As universidades também estão repensando sua organização. Os currículos de algumas estão sendo revistos e laboratórios e bibliotecas de outras, que ficaram fechados durante anos, reabertos.

\section{Há redes brasileiras com bons programas voltados aos iniciantes?}

MARLI Existem pouquíssimas iniciativas dessa natureza. Uma delas acontece em Sobral (a 248 quilometros de Fortaleza). Nesse município, segundo a lei, o profissional que está começando recebe $25 \%$ de salário a mais todos os meses para participar de um curso de formação durante o estágio probatório, que ocorre nos três primeiros anos. Também há encontros mensais organizados pela rede, voltados ao trabalho na escola, um programa destinado à ampliação do universo cultural desse público e congressos para a socialização de boas práticas.

- "A equipe gestora deve acolher e ajudar o professor iniciante"

- O que pode ser feito nas escolas para assegurar a troca de experiências?

$K \leq$ Página de $\geq \geq 1$

Gostou desta reportagem? Assine NOVA ESCOLA e receba muito mais em sua casa todos os meses!

Publicado em NOVA ESCOLA Edição 266, Outubro 2013. Título original: "A equipe gestora deve acolher e ajudar o professor iniciante" 


\section{Diários de Aulas}

\section{Journal des Cours Extras}

\section{Le 28 mars}

Le semestre a commencé et de nouveaux groupes aussi, ce qui m'a encouragé parce que j'étais un peu déjà fatiguée de ceux que j’avais le semestre dernier.

Ce semestre j'ai deux groupes du même niveau, niveau 4. Ils sont un peu différents mais j'ai l'impression qu'ils sont plus forts que les élèves que j'ai eu au niveau 4 le semestre dernier - ce qui m'inquiétait ou - je peux même dire - dérangeait un peu.

J'ai déjà tous les cours préparés, ce qui est ravissant - moins de travail. C'est vrai que je sais qu'il y a des choses encore à améliorer, des activités qui n'ont pas très bien marché le semestre dernier, mais même avec cela c'est moins de travail que tout étudier, connaître les règles pour bien les leur expliquer et trouver des activités intéressantes.

Il y a des contenus un peu délicait pour travailler au niveau 4 et je me sens, ce cette fois-ci, plus sûre de moi pour les travailler avec les élèves, mes explication sont plus claires. Le semestre est encore au début mais j'ai l'impression qui les cours où on a travailler le discours rapporté au présent, les comparaisons et la révision du passé composé ont mieux marché que de l'autre fois que je les ai donnés semestre dernier. Mon tableau est aussi plus organisé, j'en suis fière quand on fait la pause et je vois quelque chose de clair, schématisé.

J'ai vu que leur dire au début de l'explication de ne pas paniquer et juste après rigoler un peu c'est une stratégie intéressante, qui les calme un peu.

\section{Le 30 mars}

Quand j'ai planifié ce semestre en partageant les jours de cours et le contenu que je travaillerai dans chaque séance, je me suis souvenue que ça a été la folie le semestre dernier quand l'ai commencé à travailler le passé composé versus l'imparfait sans faire une bonne révision de chaque temps verbal séparément. Alors, j'ai décidé de changer ce semestre et " perdre » des cours pour les réviser et seulement ensuite travailler l'un versus l'autre. Aussi, je me suis rappellée qu'on va travailler bientôt le « Plus-que-parfait » et il faut que les élèves aient les temps du passé déjà connus bien clairs pour pouvoir bien avancer.

Alors, avec mes deux groupes j'ai fait une révision du passé composé avec beaucoup d'exercices pour s'entraîner. Ce qui m'a attiré l'attention ça a été que pas mal d'élèves n'avaient aucune idée de comment conjuger les verbes pronominaux au passé composé et ils me l'ont dit lors de la correction. C'est vrai qu'il a été un cours fatigant, j'étais épuisée à la fin, mais j'espère que cela aidera le bon déroulement des prochains cours et leurs apprentissages.

Avec mon groupe du samedi j'ai eu l'impression qu'ils avaient moins de difficultés avec le passé composé que celui de la semaine, celles qui éxistaient étaient surtout par rapport aux participes passés, je pense. Ensuite, j'ai commencé à travailler avec eux hier le passé composé versus l'imparfait, et cela n'a pas très bien marché comme je pensais. À mon avis, la différence d'usage de deux temps verbaux est bien claire, je ne sais pas pourquoi tant de questions. Je ne parle pas cela comme prof, mais si parce que je me rappelle quand j'étais étudiante de français et j'ai appris ce contenu, c'est comme en portugais. Bref, on a fait beaucoup d'exercices aussi et 
je leur ai demandé un texte à me rendre la semaine prochaine, pour que je voie s'ils commencent à maîtriser ce contenu ou non. Je compte à faire des activités orales pour travailler les deux temps verbaux ensemble, je dois encore y réflechir.

\section{Le 17 avril}

À propos des cours, on avance avec le contenu parce que la date de l'examen partiel s'approche. J'aime bien organiser au début du semestre le calendrier avec les dates des examens écrits et oraux et aussi les activités extras - l'activité lecture, par exemple, pour dire en avance aux élèves pour qu'ils s'organisent. Si jamais il y a quelqu'un qui sait qui ne pourra pas être présent lors d'une de ces dates, je leur dis déjà pour me prévenir en avance pour que je reorganise ce que la personne va faire - venir à un de mes cours pendant la semaine ou à d'un collègue. C'est vrai que cette histoire de rater un examen ou une activité importante m'agace : je sais bien que chaque cas c'est un cas mais je n'ai pas le temps de prendre soin de la vie de tous les élèves, voilà pourquoi j'insiste qu'il faut vraiment faire des efforts pour ne pas rater les dates importantes du cours.

Vu que j'ai déjà donné le niveau 4 le semestre dernier, les cours sont déjà préparés et les activités extras aussi. Ce qui m'attire l'attention c'est que je suis plus calme pour leur expliquer les contenus de grammaires et aussi je le fais de telle façon que j'ai l'impression que je suis plus claire. Je ne sais pas si c'est une impression personnelle ou si c'est bien ça, mais je me souviens que quand j'ai expliqué, par exemple, le plus-que-parfait, les élèves faisaient semblant de rien comprendre, cela me laissait un peu désesperée. Ce semestre-là, leurs gueules sont plus tranquilles et quand je leur demande si c'est clair, l'explication, et s'ils ont des questions, leurs visages sont calmes, ce qui me calme aussi. C'est vrai que rien n'est parfait et lors des activités je vois qu'il y a des élèves qui n'ont pas très bien compris les contenus et font toujours des fautes, mais à mon avis c'est beaucoup moins que le semestre dernier. Je ne sais pas si les élèves de ce semestre sont plus fort ou si moi, j'ai amélioré ma pratique, mais vraiment j'ai l'impression que cela va mieux. Même mes tableaux sont plus jolis et organisés, j'en suis fière.

\section{Le 24 avril}

Fraînchement, je n'aime pas la correction d'exercices. J'ai la sensation que je rate le temps du cours où je pourrais faire des activités plus intéressantes et qui leur provoqueraient plus de progrès. Quand l'élève n'a pas fait l'exercice et me dit ça au moment de la correction, c'est encore pire. En tant qu'élève, quand je ne fais pas le devoir j'essaie de le faire au moment de la correction pour au moins y participer. Je leur ai déjà dit cela : " on a fait un accord : si vous n'avez pas fait l'exercice, tant pis pour vous, faites-le au moment de la correction pour qu'on ne perde plus de temps ". Je ne sais pas ce que les éléves pensent de cette attitude, ils font des visages un peu sérieux, mais ça a été ça que j'ai juge le mieux à faire à ce moment-là.

\section{Guide du Moniteur}




\section{Guide du moniteur}

Cursos

Extracurriculares

de Francês

Serviço de Cultura e Extensão FFLCH/USP 


\section{Sumário}

Bienvenue aux Cursos Extracurriculares de Francês......................................................................212

Premières démarches administratives .................................................................................................212

Documentation ..................................................................................................................................

Le paiement ............................................................................................................................................

Salles et équipements à votre disposition ......................................................................................214

Les salles de classe …………………………………………………………………………………....2

La salle des moniteurs...............................................................................................................2

Système d'emprunt de matérie| ...................................................................................................22

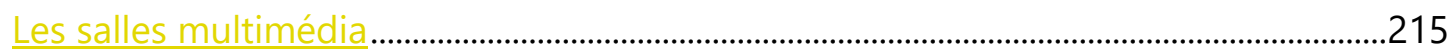

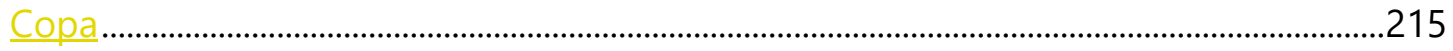

Acquisitions avant le début des cours .........................................................................................215

Les classeurs d'activités : physiques et virtuels.........................................................................216

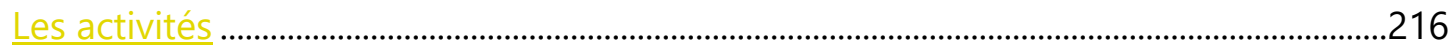

Le matériel sup plémentaire : les photocopies ..........................................................................216

Démarches administratives ...............................................................................................................217

Changement de groupe ........................................................................................................................ 217

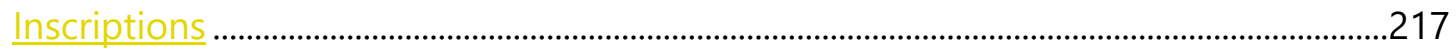

Démarches pédagogiques ...................................................................................................................218

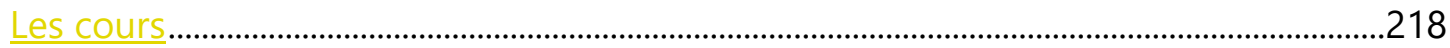

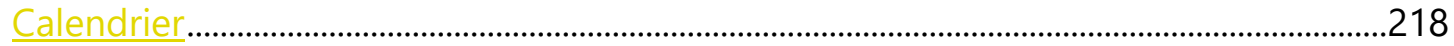

Réunions Mensuelles.........................................................................................................................219

Absences du Professeur ....................................................................................................................

Progression - Unités du livre .......................................................................................................219

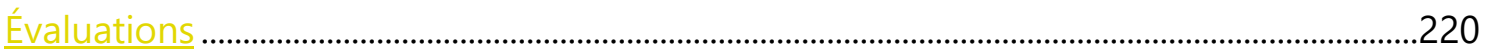

Système d'Évaluation (Notes et Fréquence) ..................................................................................221

Test de Placement .....................................................................................................................................221

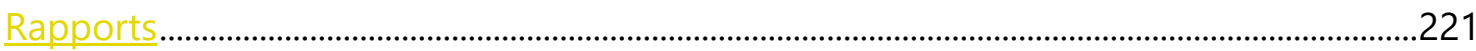

L'interruption de vos activités dans les Cursos Extracurriculares ............................................222

La continuation de vos activités dans les Cursos Extracurriculares........................................223

Adresses utiles ..................................................................................................................................224 


\section{Bienvenue aux Cursos Extracurriculares de Francês}

C'est avec un grand plaisir que nous vous recevons dans le groupe des moniteurs des Cursos Extracurriculares de Francês. Nous espérons que vous profiterez de cette expérience pour échanger et interagir avec nous en vue d'apprendre ce beau métier de professeur de français. Soyez le(a) bienvenu(e) !

Dans ce guide vous trouverez des informations essentielles à propos de l'organisation de notre cours. Pour plus d'information, vous pouvez toujours contacter notre coordinatrice Eliane Lousada (elousada@usp.br) ou les assistants à la coordination : Emily Caroline da Silva (emilycsilva@gmail.com) ou Simone Dantas (simonedantas@gmail.com).

N'oubliez pas de rejoindre notre espace virtuel, la plate-forme Moodle, à travers lequel on échange des messages et où vous trouverez plusieurs documents administratifs

et

pédagogiques

(http://moodle.redealuno.usp.br/moodle/course/view.php?id=616).

\section{Premières démarches administratives}

\section{Documentation}

C'est votre première démarche à régler. Faites-la le plus tôt possible.

2. Si vous n'avez pas un compte bancaire à la banque Banco do Brasil, prenez votre lettre de recommandation au Département Personnel (Serviço Pessoal - rhfflch@usp.br) au bâtiment de l'administration de la FFLCH..

3. Ouvrez un compte bancaire régulier à la banque Banco do Brasil (les comptes épargnes (poupança) ne sont pas acceptés). Vous pouvez ouvrir un compte Universitaire à l'agence Cidade Universitária.

4. Informez les données de votre compte bancaire à Frederico, fonctionnaire du Département Personnel.

5. Informez la coordinatrice et l'assistant de vos coordonnées (adresse mél, téléphone, date de naissance). 


\section{Le paiement}

Votre paiement sera effectué sous la forme d'une bourse qui est calculée par semestre selon les heures de cours et de réunions prévues (les réunions sont aussi payées). La valeur totale du semestre sera divisée par 5 mois et versée sur votre compte dans les mois d'avril, mai, juin, juillet et août au premier semestre ; septembre, octobre, novembre, décembre et janvier au deuxième semestre. La rémunération est de $\mathrm{R} \$ 35,00$ par heure travaillée.

Comme chaque cours a 45 heures par semestre et nous avons 15 heures de réunion par semestre ( 3 heures de réunion par mois, 5 fois par semestre), votre paiement mensuel peut être calculé selon l'équation suivante:

\section{[(Nombre de cours $x$ 45h) $+15 h$ de réunions $] \times 35,00$}

\section{5}

Si vous avez, par exemple, 1 groupe, vous recevrez $\mathrm{R} \$ 420,00$ par mois.

Si vous avez 2 groupes, vous recevrez R\$735,00 par mois.

Si vous avez 3 groupes, vous recevrez $R \$ 1050,00$ par mois.

Les tests de placement sont aussi payés, de la manière suivante :

Heures présentielles : en général, $3 \mathrm{~h}$

Heures de correction : 15 minutes par épreuve corrigée

\section{Attention :}

1. Votre documentation doit être réglée le plus tôt possible au Département Personnel au risque de délai du paiement du premier mois de travail.

2. Des réductions sont prévues en cas d'absence ou retard aux réunions.

3. Vous ne recevrez pas de paiement aux mois de février et mars (à l'exception des cours intensifs des vacances). Soyez prudent.

4. En cas de remplacement par un autre moniteur, vous devrez régler cette somme vous-même au moniteur qui vous a remplacé.

5. Vous travaillez 4 mois par semestre, mais vous recevez vos heures travaillées sur 5 mois. 


\section{Salles et équipements à votre disposition}

\section{Les salles de classe}

Nos cours ont généralement lieu dans le bâtiment de Lettres, mais certains groupes peuvent éventuellement avoir cours d'autres bâtiments de la Faculté selon la disponibilité de salles. Vous devez informer le numéro de patrimoine de votre lecteur de CD aux gardiens à chaque fois que vous le sortez et le rentrez du bâtiment.

Les salles de classe sont désignées par le Département de Lettres Modernes. Si jamais vous tombez sur une salle trop petite pour votre groupe, vous devez contacter : le service de Cultura e Extensão (agenda@usp.br) et leur expliquer la situation.

Pensez à dire à vos élèves que le personnel chargé du nettoyage et de la surveillance du bâtiment ne sont pas nos employés. De même pour les salles, qui appartiennent à I'Université de São Paulo.

\section{La salle des moniteurs}

Nous avons à notre disposition dans la salle de moniteurs une armoire avec des lecteurs de $C D$, quelques livres, quelques photocopies, quelques manuels, $C D$ et DVD et trois classeurs avec des activités préparées les derniers semestres. II y a aussi une deuxième armoire (contenant un poste de télévision, un magnétoscope et un lecteur de DVD) qui peut être déplacée seulement au deuxième étage à cause de l'escalier (si vous en avez besoin, discutez avec des moniteurs qui ont cours au même horaire pour proposer un changement de salle). Nous avons une troisième armoire où nous gardons les évaluations des élèves, les tests de placement, un ordinateur portable et les matériels de nos journées de formation. Toutes les armoires ainsi que la salle des moniteurs sont fermées à clé. Cette fermeture est essentielle pour éviter des problèmes tels que la disparition de matériel qui pourrait avoir une conséquence sur vous.

\section{Attention !}


Prenez soin des matériaux et des équipements mis à votre disposition et n'oubliez jamais de fermer toutes les portes à clé.

\section{Système d'emprunt de matériel}

Les livres et manuels qui sont notre armoire peuvent être empruntés pendant deux semaines maximum dès que le moniteur note son nom sur les listes qui sont dans la partie interne de la porte de l'armoire au moment de l'emprunt et de la remise du matériel. N'hésitez pas à vous en servir !

\section{Les salles multimédia}

Vous avez le droit d'utiliser les salles multimédia du bâtiment de Lettres. Pour cela, contactez le LAPEL et réservez la salle désirée et les équipements dont vous aurez besoin (internet, projecteur, magnétoscope, DVD). Sachez que le LAPEL est fermé le samedi.

\section{Attention !}

Les salles multimédia sont d'usage prioritaire des cours de licence, master et doctorat de la faculté. Ne les réservez pas plus de deux fois par semestre.

\section{Copa}

Vous avez le droit d'utiliser la Copa (par exemple: pour garder une marmite au frigo et la chauffer aux micro-ondes ou pour prendre un peu de café), mais n'oubliez pas de vous présenter à la responsable (Cida): dites que vous êtes moniteur aux Cursos Extras.

\section{Acquisitions avant le début des cours}

Avant le début des cours, vous devez acquérir :

- le(s) livre(s) de l'élève ;

- le(s) cahier(s) d'activités ;

- les CD audio du professeur ;

- les copies des clés dont vous aurez besoin (il faut les rendre quand vous ne serez plus moniteur). 
Pour les acquérir, vérifiez avec la coordinatrice si vous pouvez bénéficier d'un spécimen (cela dépend des disponibilités des maisons d'édition). Vous trouverez les CD audio et les DVD dans l'armoire des moniteurs. Tous les enregistrements du CD sont également dans l'ordinateur portable de la salle des moniteurs, vous pouvez les copier sur votre clé USB ou sur un CD.

En outre, nous avons un accord avec la Librairie Française et avec SBS qui vous assure une réduction de prix dans l'achat des livres prévus pour le cours. Pour en bénéficier, parlez-en à la coordinatrice.

\section{Les classeurs d'activités : physiques et virtuels}

Les trois classeurs d'activités de la salle des moniteurs sont constitués des activités présentées lors de nos réunions. Vous pouvez les consulter, mais n'oubliez jamais de tout remettre en place immédiatement après l'usage.

Vous trouverez également des activités, des textes, des jeux, des documents audio, ainsi que les évaluations et les documents administratifs sur la plateforme Moodle, dans la rubrique « arquivos » qui se trouve à gauche.

\section{Les activités}

Dans le but de construire un fonds collectif d'activités, nous comptons sur la collaboration de tous les moniteurs. Quand vous créez une activité pour votre groupe, présentez-la dans nos réunions et/ou envoyez-la à Emily (emilycsilva@gmail.com) et à Eliane (elianelousada@gmail.com) pour enrichir notre fichier. Après une révision et mise en page, votre activité sera disponible en ligne pour les autres professeurs. C'est à la fois une façon de diminuer le travail et de partager vos idées avec les collègues.

\section{Le matériel supplémentaire : les photocopies}


Comment faire imprimer les examens :

1. Vous pouvez aller à la SCEx (Serviço de Cultura e Extensão, dans le bâtiment de l'Administration) ou bien leur envoyer un e-mail (agenda@usp.br) avec les examens en fichier attaché et le nombre de photocopies nécessaires. Vous pouvez aussi vous organiser avec les autres moniteurs pour demander le nombre total d'examens.

Pour les impressions et photocopies des activités pour le cours :

1. Vous devez demander une petite somme d'argent à chaque élève pour faire les photocopies du semestre (des activités de salle de classe). Pensez à avoir un contrôle des sommes données et des dépenses que vous avez eues.

\section{Démarches administratives}

\section{Changement de groupe}

Si vous avez des élèves qui souhaitent changer de groupe, vous devez suivre la procédure suivante :

1. Vérifiez s'il y a de la place dans le groupe de destination. On n'autorise pas le changement s'il y a 20 élèves inscrits.

2. Communiquer au professeur actuel, au futur professeur et à Eliane.

3. Si tous sont d'accord, le professeur actuel écrit au secrétariat (avec Eliane et le futur professeur en copie) en autorisant le changement. Attention : tout doit être fait par écrit et par courriel (les emails sont des documents). Encouragez les apprenants à faire le changement auprès du secrétariat pour éviter des problèmes à la fin du semestre.

\section{Inscriptions}

Comme il s'agit d'un cours payant, on n'accepte jamais d'auditeurs libres, alors dans les premières semaines, faites l'appel et vérifiez si tous les élèves sont inscrits.

Au cas où il y aurait un problème d'inscription, confirmez si l'élève est ou n'est pas inscrit auprès du Secrétariat (agenda@usp.br). Si l'inscription n'est pas 
effectuée, demandez gentiment à l'apprenant de régler sa situation auprès du secrétariat.

Normalement, la liste d'inscrits est mise à jour après la rentrée. Faites donc attention pour avoir la liste correcte et n'hésitez pas à contacter le Secrétariat en ce qui concerne les inscriptions, car nous pouvons avoir des surprises désagréables à la fin du semestre.

\section{Démarches pédagogiques}

\section{Les cours}

Les cours ont une durée de trois heures qui peut être distribuée de la manière suivante : 3 heures de suite, une fois par semaine; 1 h30 deux fois par semaine (total de 45 heures de cours par semestre, par niveau).

C'est toujours intéressant de connaître le parcours des élèves en tant qu'étudiants de français. Essayez donc de demander leurs parcours d'études et leurs objectifs le premier jour, cela pourra vous aider dans le choix des documents. Dans le même but, faites un sondage les premiers cours, pour voir ce qu'il faut encore travailler avant de commencer un nouveau contenu, mais faites attention au calendrier et à la progression établie.

Pour le premier jour de cours, veuillez consulter le document « Démarches de premier jour » qui est sur la plate-forme Moodle.

\section{Calendrier}

Élaborez avec les autres moniteurs du même niveau un calendrier pour le déroulement du semestre : prenez les dates de la liste de présence et divisez les unités prévues par les jours de cours.

N'oubliez pas que le premier cours est destiné à la connaissance du groupe, à briser la glace ; le dernier cours est destiné à la remise de notes et à la correction des évaluations. Prévoyez toujours un cours de révision avant les évaluations. 


\section{Réunions Mensuelles}

Il y a une réunion à chaque mois, le vendredi de $9 \mathrm{~h} 30$ à $12 \mathrm{~h} 30$. En général, les réunions sont composées de trois parties: les questions administratives; la formation des professeurs ; la présentation d'activités.

Dans la première réunion, les moniteurs élaborent un planning des prochaines réunions, en choisissant les thèmes à étudier pendant le semestre, les moniteurs qui conduiront la discussion et les moniteurs qui présenteront les activités. Au début du semestre vous recevrez avec les dates et les thèmes qui y seront discutés.

La coordinatrice passera l'ordre du jour quelques jours avant, par mél, avec I'indication du texte à lire (fichier « Cursos Extracurriculares » à l'ordinateur dans la photocopieuse ou sur Moodle) et les points à discuter.

À la fin du semestre vous aurez un certificat indiquant les heures de formation continue auxquelles vous avez participé.

\section{Absences du Professeur}

Si vous avez une formation, présentation de travail, ou si vous avez besoin d'être absent à un cours, prévenez Eliane pour que l'on puisse trouver quelqu'un pour vous remplacer.

Au cas où personne ne pourrait échanger un cours, vous devrez trouver avec les élèves une date ou quelques minutes avant ou après le cours pour rattraper les heures perdues (attention : il ne faut jamais déranger les activités et les horaires de la faculté ; il ne faut jamais porter préjudice aux élèves en diminuant leurs 45 h de cours par semestre).

S'il y a des remplacements par des moniteurs, le paiement doit être réglé entre le moniteur qui se fait remplacer et celui qui le remplace.

\section{Progression - Unités du livre}

On suit la progression établie dans les manuels employés, selon la grille suivante : 


\begin{tabular}{|l|l|}
\hline Niveau & Alter Ego 1 \\
\hline $1($ A1.1) & Alter Ego + 1 - Dossiers 0 à 3 \\
\hline 2 (A1.2) & Alter Ego + 1 - Dossiers 4 à 6 \\
\hline 3 (A1>A2) & Alter Ego 1 - Dossiers 7 à 10 \\
\hline Niveau & Alter Ego 2 \\
\hline 4 (A2.1) & Alter Ego + 2 - Dossiers 1 à 3 \\
\hline 5 (A2.2) & Alter Ego + 2 - Dossiers 4 à 6 \\
\hline 6 (A2>B1) & Alter Ego 2 - Dossiers 7 à 9 \\
\hline Niveau & Alter Ego 3 \\
\hline 7 (B1.1) & Alter Ego 3 - Dossiers 1 à 3 \\
\hline 8 (B2.2) & Alter Ego 3 - Dossiers 4 à 6 \\
\hline 9 (B1>B2) & Alter Ego 3 - Dossiers 7 à 9 \\
\hline Niveau & Le Nouvel Edito \\
\hline 10 (B2.1) & Le Nouvel Edito (1 à 3) \\
\hline 11 (B2.2) & Le Nouvel Edito (4 à 6) \\
\hline 12 (B2>C1) & Le Nouvel Edito (7 et 8) \\
\hline
\end{tabular}

\section{Évaluations}

Les évaluations de chaque niveau sont déjà prêtes (à l'exception des niveaux donnés pour la première fois). Si vous participez à l'élaboration d'une nouvelle évaluation (notamment celles des niveaux avancés), il est essentiel que vous transmettiez cette évaluation à Eliane et Emily pour qu'on puisse la réviser et la mettre sur Moodle.

Pour la correction (pas seulement de l'évaluation, mais de toutes activités réalisées pendant le semestre), consultez le barème de correction (disponible sur Moodle) ainsi que le nombre de points appropriés pour chaque critère.

Pour l'évaluation de mi-semestre, vous pouvez la faire une seule fois, ou vous pouvez également la partager et l'appliquer par parties/habiletés.

Les élèves ne peuvent pas garder les évaluations. Après la correction, on les leur montre et on les garde dans notre armoire (mettez les évaluations dans une enveloppe avec votre nom, le niveau du groupe, l'horaire, la date et le semestre correspondant). 


\section{Système d'Évaluation (Notes et Fréquence)}

Selon le règlement de la SCEx, pour afférer un critère « admis au niveau suivant » ou "refusé au niveau suivant» on compte la moyenne minimale $(7,0)$ et la fréquence exigée (85\%).

À chaque évaluation, on évalue la compréhension orale et écrite, l'expression et la production orale et écrite, chaque habileté (CO, CE, PO, PE) vaut $25 \%$ de la note totale. La première évaluation équivaut à $40 \%$ et la deuxième à $60 \%$ de la moyenne finale.

À la fin du semestre, envoyez les moyennes finales, la fréquence et la mention « aprovado » ou « reprovado » des élèves à agenda@usp.br. Ceci doit être fait par email mais aussi par papier.

N'hésitez pas à discuter des cas particuliers avec la coordination.

\section{Test de Placement}

Il y a un test de placement pour les nouveaux élèves à la fin de chaque semestre (ou parfois au début du semestre). Le test est déjà préparé et ce sont les moniteurs qui l'appliquent, sous la supervision d'Eliane, de Simone et d'Emily. Il est composé d'une partie écrite et d'une partie orale.

En général, les moniteurs sont payés selon le temps de travail impliqué dans le test.

Après la correction, envoyez les résultats des tests à Eliane (il y a une grille déjà prête) et gardez les tests dans l'armoire, en indiquant que l'enveloppe contient des tests de placement, votre nom et la date.

\section{Rapports}

1. Listes, notes et formulaires à remettre au Secrétariat

Au début du cours, vous recevez de l'administration :

- les listes de présence ;

- les questionnaires d'opinion pour les élèves ; 
- le formulaire « rapport de fin de semestre » (relatório acadêmico).

À la fin du semestre, demandez aux élèves de répondre au questionnaire, complétez le formulaire et rendez les listes (avec les notes et la fréquence notées dans la première page de la liste), les questionnaires d'opinion et le formulaire au Secrétariat. Si vous n'avez pas reçu le formulaire avec le relatório acadêmico, vérifiez s'il en reste dans notre armoire, ou bien vous le trouverez aussi à l'adresse suivante :

\section{http://sce.fflch.usp.br/node/239}

\section{Récit d'expérience vécue}

À la fin du semestre vous devrez écrivez un rapport d'expérience vécue en tant qu'enseignant, selon les indications de la coordinatrice. Indiquez ce que vous avez appris, ce qui s'est passé pendant le semestre. Ce rapport sert à la recherche $d^{\prime}$ Eliane sur la formation de professeurs.

\section{Journal de Cours}

Pendant le semestre, écrivez des journaux sur quelques cours que vous avez faits, à la manière des journaux intimes mais écrits à propos de votre cours. Ces journaux vous aideront à écrire le rapport d'expérience vécue et pourront également être rendus à la coordinatrice.

\section{L'interruption de vos activités dans les Cursos Extracurriculares}

Vous pourrez avoir besoin d'interrompre vos activités dans les Cursos Extracurriculares, pour plusieurs raisons: une bourse CAPES, CNPq, la nécessité de se pencher un peu plus sur vos études, la possibilité de trouver un travail dans une école ou ailleurs, etc. Ceci est très naturel, car vous êtes à l'Université de passage, que ce soit au cours de $2^{\mathrm{e}}$ cycle (graduação), ou au cours de $3^{\mathrm{e}}$ cycle (master ou doctorat). Dans tous les cas, la coordination ne peut que se réjouir de vos conquêtes, sur le plan académique ou professionnel. Sachant que les Cursos Extracurriculares sont un lieu de formation, il est très important pour la coordination de savoir que ce que vous apprenez chez nous contribue pour que vous progressiez dans votre carrière : on est fiers de vous! 
Cependant, pour éviter toute sorte de problèmes qui pourraient nuire au bon fonctionnement des Cursos Extracurriculares et au développement des apprenants, il est important de suivre les indications suivantes :

- si vous attendez une bourse ou si vous avez postulé à une bourse, parlez-en à la coordinatrice et dites-lui quelles sont les prévisions pour l'obtenir.

- si vous cherchez du travail, si vous attendez une réponse ou si vous allez commencer à chercher du travail, parlez-en à la coordinatrice et dites-lui quels sont vos plans.

L'organisation des cours est une tâche assez complexe et qui demande énormément d'anticipation et de coordination entre plusieurs éléments : horaires souhaités par les moniteurs, horaires existants, nombre d'élèves dans les cours, niveaux existants, etc. Bref, l'organisation de l'emploi du temps du semestre est un vrai casse-tête. Alors, il est essentiel de prévenir la coordination à l'avance :

- au semestre précédent, quand vous devez quitter les Cursos Extracurriculares. Les emplois du temps se font aux mois de mai/juin et d'octobre/novembre : c'est à ce moment-là que vous devez parler de la nécessité de quitter les cours, pour que la coordination puisse prévoir l'emploi du temps du semestre suivant sans vous. Cela implique l'ouverture d'un Edital pour le recrutement de nouveaux moniteurs et un processus qui dure environ 45 a 60 jours.

- dès que vous commencez les démarches, quand vous demandez la bourse. II faut du temps (un mois, au minimum) pour prévoir un remplacement et le faire de manière douce, quand il s'agit d'une bourse. Ceci pour éviter que les apprenants aient des problèmes d'adaptation avec le nouveau moniteur.

\section{La continuation de vos activités dans les Cursos Extracurriculares}

De la même manière, vous pouvez être amenés à continuer pendant longtemps dans les cours extracurriculares de français. Pour ce faire, il faut renouveler votre bourse tous les ans, car cela ne se fait pas automatiquement. II faudra donc que vous soyez au processus sélectif de nouveaux moniteurs après un an de travail et que vous posiez à nouveau votre candidature : documents remis au secrétariat et 
participation à l'épreuve écrite. II n'est pas nécessaire de refaire l'entretien et vous serez, en principe, automatiquement acceptés dans les Cursos Extracurriculares.

\section{Adresses utiles}

Serviço de Cultura e Extensão

Horário de Atendimento:

Segunda a sexta-feira das 9 às $11 \mathrm{~h} 30$ e das 13 às $16 \mathrm{~h} 30$.

Prédio da Administração da FFLCH

Rua do Lago, 717 - sala 126.

Téléphone: 3091-4645

E-mail:

Recursos Humanos FFLCH-USP

Téléphone: 3091-4631/ 4757

E-mail:

Tesouraria

Téléphone: 3091-4579

E-mail:

LAPEL

E-mail: lapel@usp.br

Departamento de Letras Modernas

Av. Prof. Luciano Gualberto, 403, sala 15.

Secretaria de graduação

Téléphone: 3091-5041

E-mail:

Secretaria de pós-graduação

Téléphone: 3091-4296

E-mail:

Eliane Lousada

Téléphone: 981930217 
E-mail: elousada@usp.br

Emily Caroline da Silva

Téléphone: 997358042

E-mail : emilycsilva@gmail.com

Simone Dantas

Téléphone : 986777002

E-mail : simonedantas@gmail.com 